Wator-Supply and Irrigation Paper No. 147 Series M, General Hydrographic Investigations, 15

DEPARTMENT OF THE INTERIOR

UNITED STATES GEOLOGICAL SURVEY

CHARLES D. WALCOTT, DRRETOR

\title{
DESTRUCTIVE FLOODS IN THE UNITED STATES IN 1904
}

BY

\section{EDWARD CHARLES MURPHY AND OTHERS}

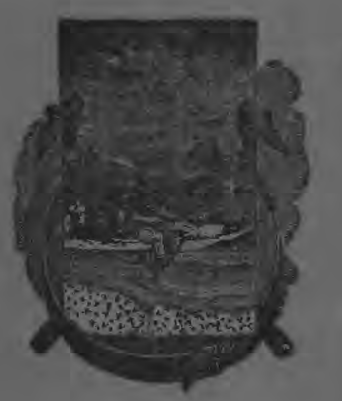

WASHINGTON

GOVERNMENT PRINTING OFWICE 1905 


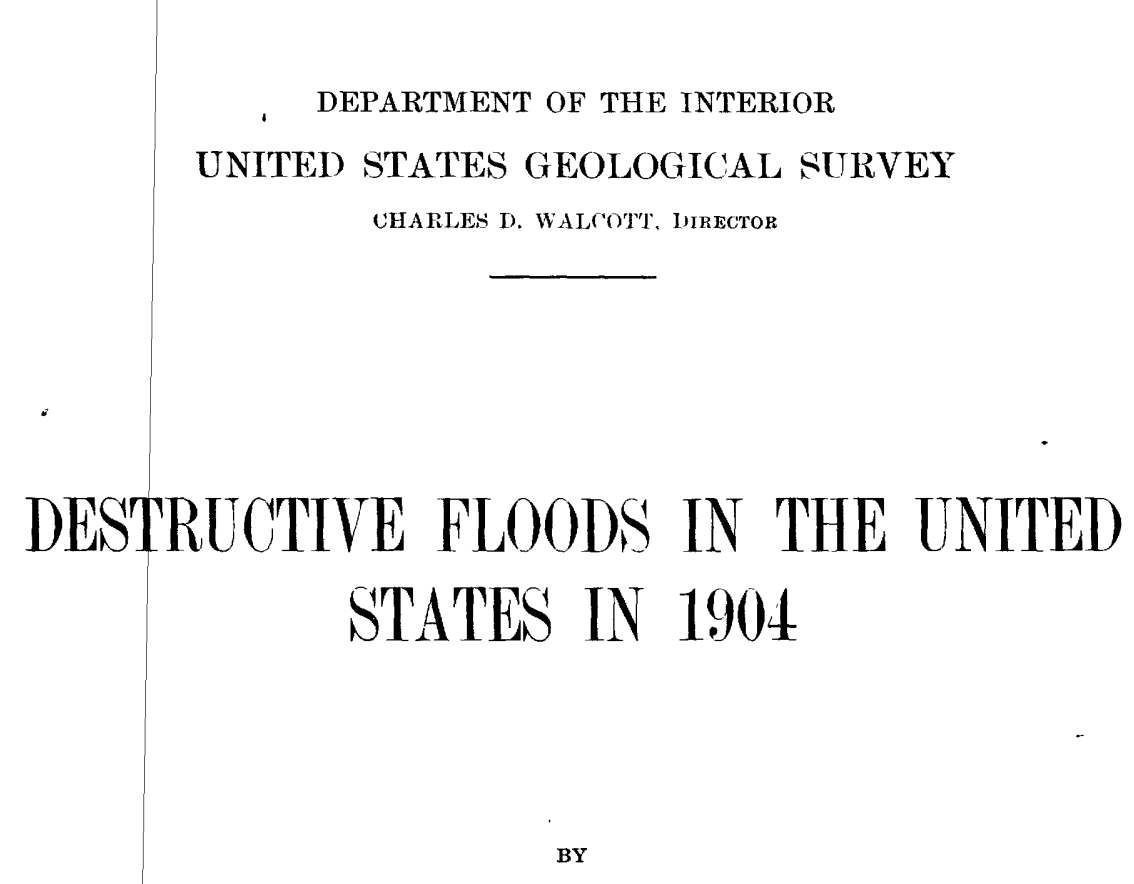

\section{EDWARD CHARLES MURPHY} AND OTHERS

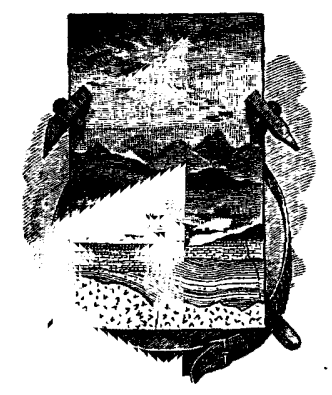

W A SH I N GTON

GOVERNMENT PRINTING OFFICE 1905 



\section{0 N T E N T S.}

Page.

Letter of transmittal $\ldots \ldots \ldots \ldots$

Introduction . . . . . . 11

Sacramento River flood, California, from report of S. G. Bennett. . . . . 12

Streams and drainage basin ................................ 12

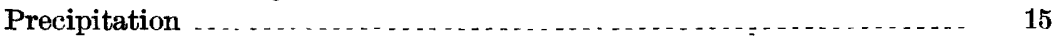

Gage height and discharge $\ldots \ldots \ldots \ldots$

Obstruction of channel .

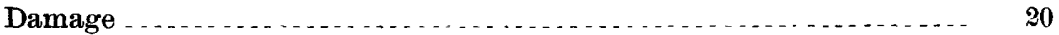

Prevention of future damage $\ldots \ldots \ldots \ldots$

Susquehanna River flood. Pennsylvania, by E. C. Murphy ............. 22

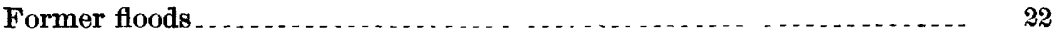

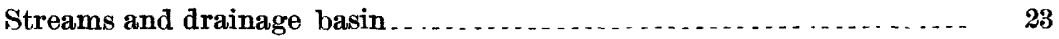

Precipitation

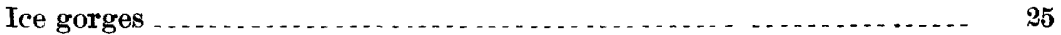

Gage height and discharge $\ldots \ldots \ldots \ldots \ldots$

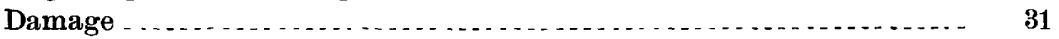

Prevention of future damage ...

Mohawk River flood, New York, from report of R. E. Horton .......... 32

Streams and drainage basin .................................... 32

Precipitation and temperature............................. 33

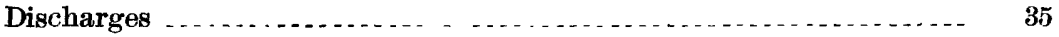

Damage . . . . . . .

Grand River flood. Michigan, from report of R. E. Horton.......... 40

Streams and drainage basin . . . . . . .

Precipitation and temperature

Gage height and discharge $\ldots \ldots \ldots \ldots . . . \ldots 2$

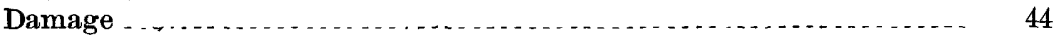

Prevention of future damage $\ldots \ldots$

Wabash River flood, Indiana, by F. W. Hanna . .

Streams and drainage basin

Precipitation .............. 46

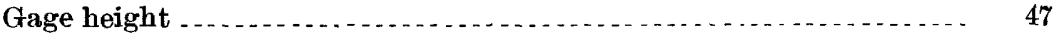

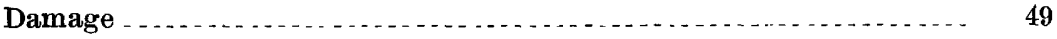

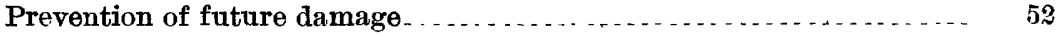

Belle Fourche River flood. South Dakota, from report of R. F. Walter

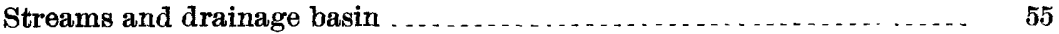

Precipitation ..........................

Gage height and discharge $\ldots \ldots$

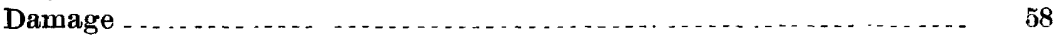


Kansas floods, by E. C. Murphy $\ldots \ldots \ldots \ldots \ldots \ldots \ldots$

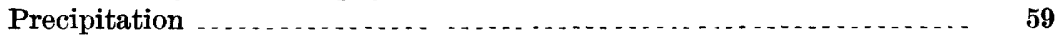

Kansas River flood . . . .

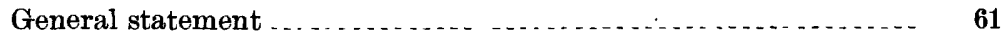

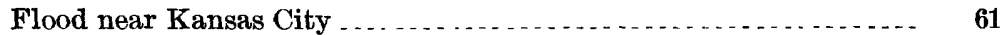

Gage height and discharge $\ldots \ldots \ldots \ldots$

Necessary waterway ........................................ 64

Recommendations of board of army engineers . . . . . . . . . . 65

Flood near Lawrence . . . . . . . . . . . . . . . 66

Flood near Lecompton . . . . .

Gage height and discharge $\ldots \ldots$

Necessary waterway . . . .

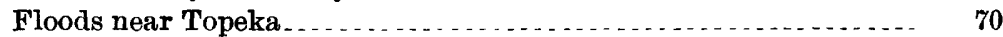

Gage height _.......... 70

Obstructions in channel ...............................

Flood near Manhattan .................................. 73

Flood near Junction . . . . . . . .

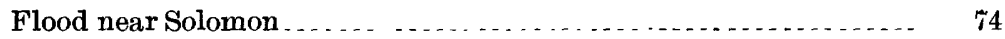

Comparison of floods of 1903 and $1904 \ldots \ldots \ldots$

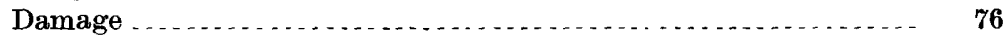

Prevention of future damage ...

Neosho River floods ........ . . . . . . . . . . . . . . . . . . . . . . . . 78

Streams and drainage basin . . . . . . .

Discharge and run-off . . . . . . . . .

Flood near Iola $\ldots \ldots \ldots \ldots \ldots \ldots$

Flood near Humboldt. . . . . . . . . . . . . . . . . .

Flood near Neosho Rapids . . . . . . . . . . . . . . . . . . . . . 59

Flood near Emporia ............. . . . . . . . . .

Flood near Chanute . . .

Flood near Fort Gibson $\ldots \ldots \ldots$

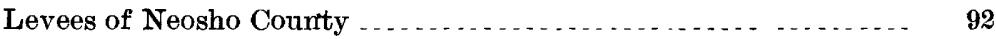

Necessary width of channel . . . .

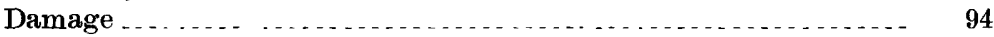

Prevention of future damage $\ldots \ldots \ldots$

Verdigris River floods ............ 94

Streams and drainage basin $\ldots \ldots \ldots$

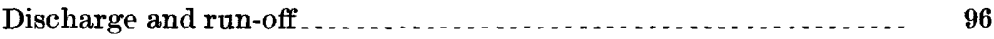

Floods near Independence . . . . . . . . . . . . . . . . . . . . . 101

Flood on the lower Verdigris . . . .

Flood in lower Fall River Valley _. . . . . . . . . . . . . . . . . 104

Necessary width of channel of Verdigris River . . . . . . . .

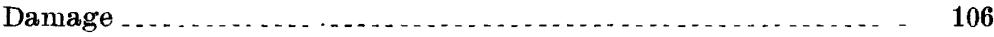

Osage River floods ...

Stream and drainage basin . . . . . . . .

Gage height and discharge . . . . . . . .

Damage ... . .

Prevention of future damage . . . . . . . . . . . . . . . . 109

Arkansas River floods ....... . . . . . . . . . . . . . . . . . . . . . . . . . 109

Gage height and discharge ............... 109

Flood near Arkansas City . . . . . . . . 110

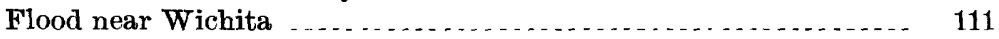

Flood on Walnut River . . . . . . . . . . . . . . . . . . . . . . 112 
Pennsylvania floods, by E. C. Murphy

Page.

Johnstown flood

Robinson Run flood

Troxton Canyon flood, Arizona, by E. C. Murphy $\ldots \ldots \ldots$

Globe flood, Arizona, by O. T. Reedy _........... 118

Canadian River basin flood, New Mexico, Oklahoma, and Indian Territory,

from report of Frank S. Dobson and George B. Monk ......

Streams and drainage basin . . . . . . . .

Precipitation

Flood on Canadian River

Flood on Ute Creek

Flood on Sapello River.

Flood on Rio Mora $\ldots \ldots \ldots$

Obstruction of streams . . .

Damage

Streams and drainage basin . .

Precipitation ............... 131

Flood on the Pecos.

Flood on Gallinas River 138

Flood on Hondo River $\ldots \ldots$

Damage . . .

Prevention of future damage $\ldots \ldots \ldots 1$

Failures of Lake Avalon dam near Carlsbad, N. Mex., by E. C. Murphy ... $\quad 141$

Rio Grande floods, New Mexico, by E. C. Murphy ...

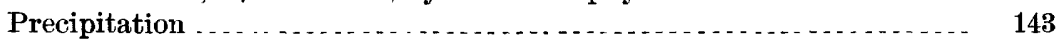

Flood in southern New Mexico................. 143

Flood in northern and central New Mexico $\ldots \ldots$

Damage . . . . . . . 149

Floods in the Denver district, by M. C. Hinderlider and ass stants . . . . $\quad 150$

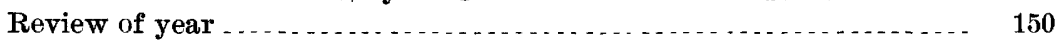

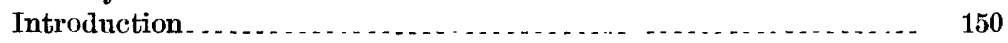

Flood stations . . .

Cause of floods.............

Damage ........ . . .

Prevention of future damage $\ldots \ldots \ldots$

Cache la Poudre River and Crow Creek flood $\ldots \ldots$

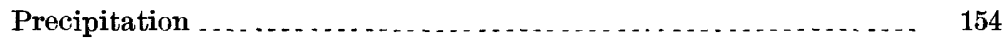

Flood on Cache la Poudre River.

Flood on Crow Creek ............. 156

Purgatory River flood, by R. I. Meeker.

Stream and drainage basin $\ldots$

Precipitation ............ 160

Flood on the Purgatory proper

Flood near Trinidad $\ldots 1$

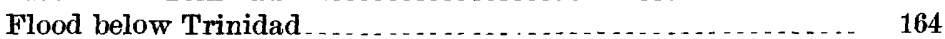

Purgatory flood on the Arkansas.

In Colorado $\ldots \ldots \ldots$

In Kansas . .

Damage ...... . . . . .

La Plata River flood, Colorado, from report of Theo. Tobish . . . . . . . 169 
Floods due to failure of dams and reservoir walls, by E. C. Murphy

General statement

172

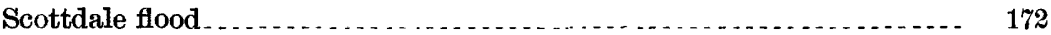

Drought in Ohio River drainage basin, by E. C. Murphy . . . . . . . . 173

Introduction ...................... 173

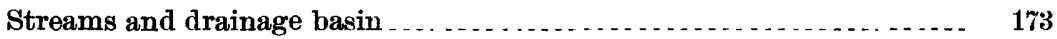

Precipitation ..................... 174

Run-off and discharge.

Some effects of the drought $\ldots \ldots \ldots 1$

A method of computing cross-section area of waterways, by E. C. Murphy - $\quad 183$

Factors determining maximum discharge ..................... 183

Maximum rate of discharge of various streams . . . . . . . . . . . . . . . 184

Formulas for maximum discharge and area of cross section. . . . . . . 189

General summary . . . . . . .

Index 


\section{ILLUSTRATIONS.}

Plate I. Draỉnage basin of Sacramento River

II. Flood of March 8, 1904, on Susquehanna River at Yorkhaven.

Pa., at its height ....................................... 22

III. Ice gorge of 1875 on Susquehanna River at Wilkesbarre, Pa $\ldots \ldots$.

IV. $B$, Damage to Chicago and Northwestern Railway along Whitewood Creek, South Dakota; A, Missouri Pacific and Union Pacific railway bridges over Kansas River at Kansas City during flood of 1904

V. Kansas City. showing area flooded in 1903 and 1904 Melan bridge, Topeka, Kans.; $B$, Ruins of Denver and Rio Grande Railway bridge, Trinidad, Colo .

VII. $A$, Flood in Neosho River at highway bridge at Humboldt, Kans.; $B$, Overflow of right bank of Neosho River at highway bridge

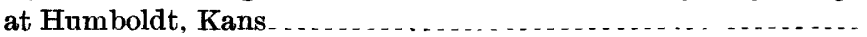

VIII. View showing effect of flood on abutments and bridge No. 604, Santa Fe Railway, Troxton Canyon. . . . . . . . . .

IX. Drainage basin and profile of Canadian River $\ldots \ldots$

X. Drainage basin and profile of Pecos River . . .

XI. A, Dam on Pecos River at Carlsbad, N. Mex., before the flood of October, 1904: $B$, Dam at Carlsbad, N. Mex., after the flood of October, 1904

XII. Flood at dam on Pecos River at Carlsbad, N. Mex., October, 1904.

XIII. Flume of Barstow Irrigation Company, Pecos River, Texas, carried away by flood October 5,1904 .

XIV. $A$ and $B$, Destruction caused by flood on Purgatory River at Trinidad, Colo.

XV. A, Atchison, Topeka and Santa Fe Railway station at Trinidad, Colo., after flood of September, 1904; $B$, View showing failure of dam near Scottdale, Pa . . . . . . . . . . . . . . . . . . . . . . . . .

XVI. Erosion of banks of Purgatory River, Trinidad, Colo ...........

XVII. Drainage basin of Ohio River $\ldots \ldots \ldots \ldots$ XVIII. Big Sandy River, near mouth, showing extreme low-water condi-
tions in November, 1904 ...

Fit. 1. Drainage basin of Susquehanna River
2. Drainage basin and profile of Mohawk River

3. Drainage basin and profile of Grand River, Michigan . .

4. Drainage basin of Wabash River ...

5. Part of Black Hills drainage . . . .

6. Flood discharge of Kansas River at Lecompton, Kans., in 1909, 1903,

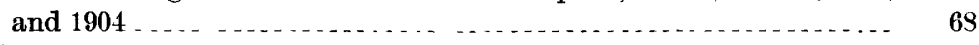

7. Cross section of Kansas River at Melan arch bridge. Topeka, Kans

8. Kansas River and flooded area in vicinity of Topeka, Kans ....... 72 
FiG. 9. Drainage basins of southeastern Kansas

Page.

10. Erosion of bank of Big Sandy Creek and relocation of Santa Fe Railway. Troxton Canyon, Arizona . . . . . . . . . . . . . . . . . .

11. Design of east abutment of bridge No. 604, Santa Fe Railway, Troxton Canyon, Arizona ............................. 117

12. Upper portion of drainage basin of Canadian River ............ 121

13. Drainage basin of the Rio Grande . . . . . . . . . . . . . . . . . . . . . . 14

14. Drainage basins of Cache la Poudre River and Crow Creek . . . . . 155

15. Drainage basin of Purgatory River . . . . . 159

16. Area overflowed and area eroded at Trinidad, Colo., by Purgatory River flood ....

17. Drainage basin of La Plata River and area of heaviest rainfall on October 8, 1904 . . . .

18. Curve showing mean annual precipitation at three places in the Ohio River drainage basin from 1830 to 1904

19. Curve showing relation between size of drainage basin and rum-off per square mile 


\title{
LETTER OF TRANSMITTAL.
}

\author{
DePaRTMENT OF THE INTERIOR, \\ United States Geological Survey, \\ Division of HYdrography, \\ Washington, D. C., A pril 10, 1905.
}

SIR: I transmit herewith a manuscript, prepared by E. C. Murphy, entitled "Destructive Floods in the United States in 1904," and request that it be published as a water-supply paper.

The value of property along the streams of this country is rapidly increasing and data on the flood flow of streams and means of preventing overflow are of increasing interest and value.

Data on the other extreme of stream flow are also of increasing interest and value, as droughts affect not only the agriculture and navigation interests of the country, but also, to a considerable extent, its manufacturing and transportation interests.

Very respectfully,

F. H. Newell, Chief Engineer.

Hon. Charles D. Walcott,

Director United States Geological Survey. 



\section{DESTRUCTIVE FLOODS IN THE UNITED STATES IN 1904.}

By E. C. Murphy and others.

\section{INTRODUCTION.}

Destructive floods occurred on several streams of the United States during the year 1904, mainly on the smaller streams in the western part of the country. The loss of property caused by these floods, while large in the aggregate, is small compared with flood losses of some previous years.

The first in chronologic order in the list of destructive floods of 1904 is that on Sacramento River in California, which occurred in February and which was the most destructive in the records of that stream. In March occurred the flood on Susquehanna River, due mainly to ice gorges; the flood of Mohawk River in New York and that of Grand River in Michigan, due mainly to the rapid melting of snow ; and the flood on Wabash River, due mainly to rainfall. In May very heavy rains in northern Colorado and southern Wyoming caused a flood on Cache la Poudre River and Crow Creek, which . resulted in the loss of considerable property along them. In the early part of June the Belle Fourche and other streams on the northern slope of the Black Hills were in destructive flood. In the latter part of June and the early part of July continued heavy rain caused the rivers in southeastern Kansas to be higher than ever known before and to cause much damage. Several cloud-bursts occurred in this month, causing local floods in western Pennsylvania and western Arizona. The Johnstown, Pa., and the Troxton Canyon, Arizona, floods are examples of these. Very heavy precipitation during the latter part of September and the early part of October in southern Colorado, New Mexico, and Texas caused floods of unprecedented rnagnitude on Purgatory, Canadian, Pecos, and other streams of that region.

After these floods in the western part of the country there was a severe drought in the eastern part. This was felt most keenly in the upper part of the Ohio drainage basin and to a lesser extent in the Southern and New England States. This drought is briefly described in this paper. 
The United States Geological Survey has carried on a study of the water resources of the country for the past seventeen years, and there is now available for the use of engineers and others interested a large mass of data bearing on the seasonal flow of the principal streams of the country. In this paper that part of these data which bears on the maximum rate of run-off of streams is brought together and a method is given for the determination of the waterway area of streams.

The writer acknowledges his indebtedness for data used in the preparation of this paper to Mr. F. H. Newell, chief engineer of the Reclamation Service and hydrographer in charge of stream-gaging work; Messrs. J. B. Lippincott, B. M. Hall, A. L. Fellows, M. C. Hinderlider, W. M. Reed, G. H. Matthes, and R. E. Horton, in charge of the districts in which the floods described in this paper have occurred; and especially to S. G. Bennett, Raymond F. Walter, F. W. Hanna, J. C. Hoyt, James A. Armstrong, A. J. Parshall, R. I. Meeker, George B. Monk, W. G. Russell, Frank S. Dobson, and T. Tobish.

\section{SACRAMENTO RIVER FLOOD, CALIFORNIA. $a$}

From February 15 to the end of March, 1904, occurred the most destructive flood, as far as property was concerned, in the recorded history of Sacramento. The greatest known flood oceurred fortyodd years before, in January, 1862, and was due to rainfall, the precipitation in December, 1861, and January, 1862, just prior to it having been 23.62 inches. This flood filled the entire flood plain, and was not limited, as was the later one, by the reclamation of large tracts of bottom land, nor was the channel below the mouth of Feather River then filled with mining débris as it is now.

STREAMS AND DRAINAGE BASIN.

Sacramento River rises in the northern part of California, flows in a general southerly direction for about 260 miles and empties into Suisun Bay. Its chief tributaries are Pitt, McCloud, Feather, and American rivers, entering from the east, and Cache, Putah, and Stony creeks, entering from the west. These streams and the location of the gaging and precipitation stations in this basin are shown in Pl. I.

Between the Sierra Nevada and the Coast Range of mountains lies what is called the Great Valley of California, having a length of about 400 miles and a width varying from a few miles to 80 miles, the average width being $40^{\circ}$ miles. It has a gentle slope, being practically an unbroken plain, with an area of about 15,700 square miles.

a Prepared from report of S. G. Bennett, engineer. 


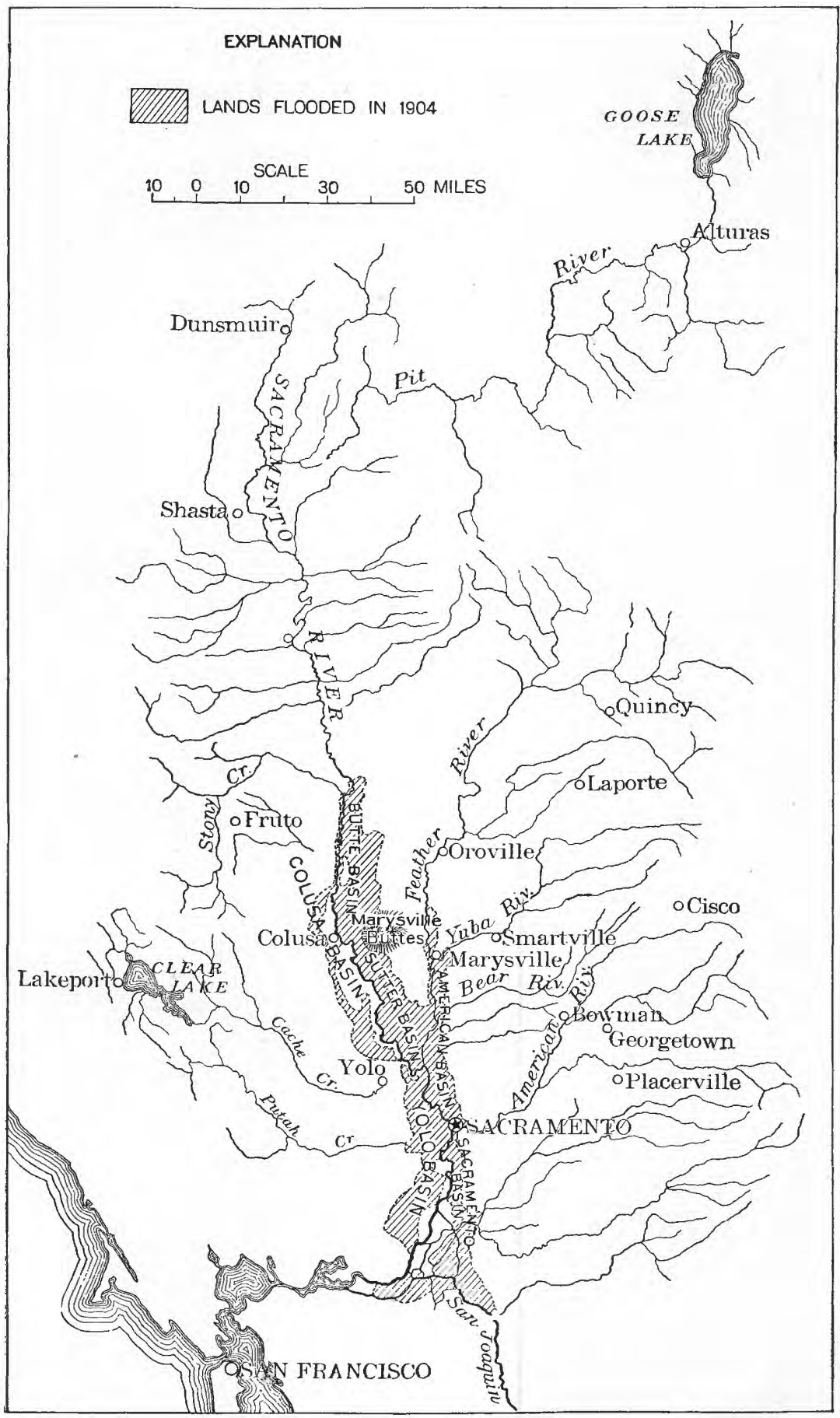

DRAINAGE BASIN OF SACRAMENTO RIVER. 
The northern portion of this valley is drained by the Sacramento; the southern part by the San Joaquin River.

What is commonly known as Sacramento Valley extends only as far north as Iron Canyon, 4 miles beyond Red Bluff. The part of . the drainage basin above this canyon is very different in topography from that below it, being mainly hilly and mountainous, with steep slopes and rapid run-off, while the valley below this canyon has a remarkably uniform slope. At Red Bluff the elevation is about 300 feet above sea level, near Colusa it is 50 feet above sea level, and at Sacramento it is $\mathbf{1 1}$ feet-that is, from Red Bluff to Colusa there is a fall of 250 feet in 65 miles, and from Colusa to Sacramento there is a fall of 39 feet in 50 miles. The area of Sacramento Valley is about 4,250 square miles, 2,510 square miles being high plains or hilly land, not subject to overflow, 450 square miles subject to occasional overflow, $1,25 \pm$ square miles naturally subject to overflow, and 38 square miles constituting the surfaces of perennial streams.

Sacramento Valley below the mouth of Stony Creek is a typical flood plain, the river banks being from 5 to 20 feet higher than the land on either side of the channel. The lowlands on each side subject to overflow are known as flood basins. They are connected with the river by old river channels, known as sloughs, through which the water enters the basins at ordinary and high stages. During flood stages the river overflows both banks, as the channel capacity in some places is only about one-third that of the flood plain of the river.

Butte basin lies on the east side of Sacramento River and northwest of the Sutter Buttes. At flood stages the water in this basin covers an area of from 30 to 150 square miles, and has a volume of from 115,000 to 460,000 acre-feet. It receives water from the river, from creeks, and during great floods from Feather River, and discharges into Sutter basin.

Sutter basin lies south of the Sutter Buttes, between Sacramento and Feather rivers. In time of flood the water surface has an area of 138 square miles, and the basin has a maximum capacity of 895,000 acre-feet. This basin discharges into Sacramento and Feather river:s near the mouth of the latter.

Colusa basin lies west of Sacramento River, and is bounded on the south by a ridge of débris brought down by Cache Creek. It is about 50 miles long and from 2 to 7 miles wide, and has a capacity at ordinary stages of 690,000 acre-feet. It drains into Sacramento River above Knights Landing.

American basin extends from American River to a point about 9 miles above the mouth of Feather River. It has an area of about 110 square miles, and contains at ordinary flood stages 345,000 acre-feet, its maximum capacity being approximately 575,000 acre-feet. It receives the water which escapes through breaks in the east banks of 
Sacramento and Feather rivers, through the south-side levees of Bear River; and from the Sierra Nevada foothills between American and Bear rivers.

Sacramento basin is a long, narrow depression, east of Sacramento River and south of the city of Sacramento. It has been protected for a number of years from overflow by levees.

Yolo basin lies on the west side of Sacramento River below Knights Landing. It is the largest of the flood basins, and has a length of 40 miles and an average width of 7 miles. During floods it contains about 1,150,000 acre-feet of water. It is a by-pass for the excess flood water of the Sacramento. An outlet through Cache Slough, which enters the main river at the foot of Grand Island, discharges at times more than donble as much as the main river. The effect of this body of water, which stands at the same elevation as the river, is to increase the high-water stage near the foot of Grand Island if the basin receives a large volume of water suddenly through a break in the west side of the levees. Much damage has been caused to the reclamation work on the delta island on this account.

The total approximate storage capacity of these basins, not inclnding the Sacramento basin, is $3,800,000$ acre-feet.

The Sacramento below Red Bluff flows in a channel that is in places raised above the surface of the country on either side. The banks are low and there are sloughs that lead the water into the overflow basins. The slope of the channel is small, so that the flow is shuggish. The channel cross section is much smaller than that of the flood flow, so that the river sometimes overflows its banks and floods the country for many miles on each side. The river was formerly navigable to Red Bluff, and there was a rise and fall of the tides at Sacramento of 2 feet in 1860 . Now the tidal effect is not felt at Sacramento and the bed of the river there is higher than the surface of low water some years ago.

Feather River breaks through the foothills into Sacramento Valley at Oroville. Its mountain drainage is fan shaped and the water collected when rains are general sometimes causes tremendous freshets of short duration. The river has at such times overflowed its right bank and submerged the relatively high-plain lands northwest of the Sutter Buttes.

There has been a great change in the channel of this river in recent years. In 1849 it was a clear-water stream falling over bars of gravel and cobbles lying between well-defined banks to its junction with Iuba River. Tidal influence extended for some distance up the river. The bottom lands along Yuba and Feather rivers in their original condition were inundated only at times of extraordinary floods. Now Feather River below Yuba River has become the repository of so much mining débris that its channel has been nearly filled, 
its bottom being nearly at the height of its former banks. The water plain at Marysville at low stage of Yuba and Feather rivers is now at least 15 feet higher than it was in 1849 .

Feather and Yuba rivers were once navigable streams. Up to 1862 the Yuba was navigable all the year for ships and boats drawing from 9 to 10 feet of water, and during the entire season deepwater ships and steamers from around Cape Horn navigated to Marysville. At the present time the channel of Yuba River is entirely filled with mining débris and Feather River is practically unnavigable.

\section{PRECIPITATION.}

The monthly precipitation at 14 places in the Sacramento River drainage basin for the seasonal year $1903-4$ is given in the table below, which shows clearly the excessive precipitation at all stations of high elevation in this watershed during February and March, 1904. The records for Red Bluff and Sacramento are taken as typical of the precipitation of the Sacramento Valley. Fifty per cent or more of the total yearly precipitation fell during these two months, the rainfall being from 100 to 250 per cent above the normal. The precipitation was 7.37 inches at Mount St. Helena on March 17 and 6.58 inches at Mount Shasta on March 15 and was 2 or more inches daily at several places. Some of this precipitation fell as snow and did not at once find its way into the streams as run-off; otherwise the resulting flood would have been much larger than it was.

Monthly precipitation at certain points in the catershed of Sacramento River. California, for the season 1903-4.

\begin{tabular}{|c|c|c|c|c|c|c|c|c|c|c|c|c|c|}
\hline Basin and station. & Sept. & Oct. & Nov. & Dec. & Jan. & Feb. & Mar. & Apr. & May. & June. & July. & Aug. & Total. \\
\hline \multicolumn{14}{|l|}{$\begin{array}{l}\text { Upper Sacra- } \\
\text { mento: }\end{array}$} \\
\hline Dunsmuir $a_{\ldots} .$. & 0.00 & 2.27 & 16.94 & 6.84 & 5.03 & 24.00 & 22.90 & 4.33 & 0.00 & 0.00 & 0.00 & 0.00 & 81.31 \\
\hline Shasta $a \ldots \ldots$ & .17 & 2.05 & 19.67 & 4.78 & 2.79 & 24.86 & 16.37 & 7.84 & .07 & .00 & .04 & .00 & 78.64 \\
\hline Johns Camp $\alpha_{-}$ & .00 & 5.06 & 21.85 & 4.85 & 4.50 & 19.73 & 27.26 & 10.90 & .00 & .00 & .00 & .00 & 94.15 \\
\hline Feather: & & & & & & & & & & & & & \\
\hline Quincy $a$ & .35 & 1.53 & 14.08 & 3.72 & 2.46 & 22.10 & 10.83 & 1.97 & .74 & T. & .05 & .12 & 57.95 \\
\hline Butte Valley $a$ & $\cdots$ & - & 15.90 & 5.50 & 4.20 & 22.90 & 22.10 & 6.65 & .65 & $\mathbf{T}$. & .70 & .90 & $b 79.50$ \\
\hline Yuba: & & & & & & & & & & & & & \\
\hline Laportea & .40 & 3.50 & 27.64 & 6.46 & 4.48 & 30.35 & 31.66 & 7.63 & .98 & .24 & .10 & .58 & 114.02 \\
\hline $\begin{array}{c}\text { Bow ma } \mathbf{n} \\
\text { Dama }\end{array}$ & .00 & 4.03 & 31.27 & 6.19 & 5. 37 & 45.61 & 39.51 & 8.52 & 1.37 & .15 & .20 & .11 & 142.33 \\
\hline American: & & & & & & & & & & & & & \\
\hline Cisco $a \ldots \ldots$ & .00 & 1.00 & 16.90 & 2.80 & 5. 20 & 30.80 & 26.87 & 5.20 & .80 & $\mathbf{T}$. & .00 & .50 & 90.07 \\
\hline $\begin{array}{l}\text { Georgetown } a_{-} \\
\text {Cache Creek: }\end{array}$ & $\mathrm{T}$. & 1.39 & 17.71 & 2.07 & 4.79 & 26.02 & 21.17 & 6.52 & .81 & .00 & .00 & .05 & 79.53 \\
\hline $\begin{array}{r}\mathbf{L} \text { a } \mathbf{k} \text { e p o } \\
(\text { near) } \\
G\end{array}$ & .00 & .36 & 5.29 & 3.18 & 1.40 & 8. 78 & 7.74 & 2.17 & .00 & & .00 & .00 & 28.92 \\
\hline
\end{tabular}


Monthly precipitation at certain points in the watershed of Sacramento River, California, for the season 1903-4-Continued.

\begin{tabular}{|c|c|c|c|c|c|c|c|c|c|c|c|c|c|}
\hline Basin and station. & Sept. & Oct. & Nov. & Dec. & Jan. & Feb. & Mar. & Apr. & May. & June. & July. & 7. Aug. & Total. \\
\hline $\begin{array}{l}\text { utah Creek: } \\
\text { Helen } a\end{array}$ & .00 & 2.75 & 27.62 & 5.63 & 4. 52 & 34.22 & 31.48 & 8.12 & .00 & .20 & .10 & .00 & 114.64 \\
\hline$\underset{\text { Helena } b}{\text { Mount. }} \mathbf{s t}$ & .00 & 2.00 & & 6.75 & 3.37 & 28.34 & 26.14 & 5.19 & .05 & $\mathrm{~T}$. & .22 & .00 & 72.06 \\
\hline $\begin{array}{l}\text { Sacramento Val- } \\
\text { ley: }\end{array}$ & & & & & & & & & & & & & \\
\hline Red B & .00 & .46 & 7.99 & 3.73 & 1.44 & 6.63 & 8.33 & 2.90 & .04 & $\mathrm{~T}$. &, 11 & 00 & 31.63 \\
\hline Sacramento $a$. & .00 & .12 & 3.44 & 1.12 & .45 & 5.26 & 5.43 & 1.02 & .03 & $\mathrm{~T}$ & T. & 07 & 16.94 \\
\hline
\end{tabular}

a Authority of Andrew Rocca.

${ }^{b}$ Authority of the United States Weather Bureau.

\section{GAGE HEIGHT AND DISCHARGE.}

The United States Geological Survey had five gaging stations in this drainage basin during this flood-one on Sacramento River at Red Bluff, one on Feather River at Oroville, one on Yuba River at Smartsville, one on Stony Creek near Fruto, and one on Cache Creek near Yolo. The mean daily discharge during the fifty days of the flood (February 11 to March 31) is given in the table below. About 72 per cent of the total mountain and foothills drainage area of the basin is above these gaging stations. The daily discharge for the remaining 28 per cent has been estimated, and the total daily discharge for all the mountain and foothills area is given in the last column.

Daily mean gage height and discharge in Sacramento basin, February 11-Marrh 31, 1904 .

\begin{tabular}{|c|c|c|c|c|c|c|}
\hline \multirow{2}{*}{ Date. } & \multicolumn{2}{|c|}{$\begin{array}{l}\text { Sacramento River at } \\
\text { Iron Canyon, near } \\
\text { Red Bluff, Cal. }\end{array}$} & \multicolumn{2}{|c|}{$\begin{array}{c}\text { Stony Creek at Julians, } \\
\text { Cal. }\end{array}$} & \multicolumn{2}{|c|}{$\begin{array}{c}\text { Cache Creek at Yolo. } \\
\text { Cal. }\end{array}$} \\
\hline & $\begin{array}{c}\text { Gage } \\
\text { height. }\end{array}$ & Discharge. & $\begin{array}{c}\text { Gage } \\
\text { height. }\end{array}$ & Discharge. & $\begin{array}{c}\text { Gage } \\
\text { height. }\end{array}$ & Discharge. \\
\hline February 11 & $\begin{array}{l}\text { Feet. } \\
\quad 3.30\end{array}$ & $\begin{array}{l}\text { Sec. feet. } \\
\quad 11,040\end{array}$ & $\begin{array}{l}\text { Feet. } \\
\quad 4.20\end{array}$ & $\begin{array}{r}\text { Sec. feet. } \\
210\end{array}$ & $\begin{array}{l}\text { Feet. } \\
2.50\end{array}$ & $\begin{aligned} & \text { Sec. feet. } \\
& 270\end{aligned}$ \\
\hline February 12 & 3.30 & 11,040 & 9.00 & 5,270 & 5.95 & 1,998 \\
\hline February 13 & 6.30 & 22,360 & 6. 25 & 1,630 & 9.25 & 4,400 \\
\hline February 14 & 6.30 & 22,360 & 5.45 & 942 & 5.50 & 1,705 \\
\hline February 15 & 17.35 & 84,790 & 8.25 & 4,055 & 5.25 & $1,55 j$ \\
\hline February 16 & $a 28.00$ & 184,600 & 12.25 & 15,450 & 16.75 & 11,250 \\
\hline February 17 & 15.20 & 69,560 & 8.25 & 4,055 & 8.75 & 4,012 \\
\hline February 18 . & 11.20 & 45,280 & $\tau .20$ & 2,660 & 7.00 & 2,700 \\
\hline February 19 & 9.55 & 36,940 & 6.65 & 2,035 & 5.80 & 1,900 \\
\hline February 20 & 9.90 & 38,620 & 5.85 & 1,265 & 5.10 & 1,465 \\
\hline February 21 & 12.50 & 52,600 & 7.85 & 3,480 & 4.90 & 1,350 \\
\hline February $22 \ldots$ & 20.30 & 108,480 & 11.75 & 13,200 & 11.00 & 5,900 \\
\hline February 23 & 16.60 & 79,320 & 8.85 & 5,015 & 14.75 & 9,275 \\
\hline
\end{tabular}

a Gage height 9 a. m.; highest known gage height, 31.0, same night. 
Daily mean gage height and discharge in Sacramento basin, February 11-March 31. 1904-Continued.

\begin{tabular}{|c|c|c|c|c|c|c|}
\hline \multirow{2}{*}{ Date. } & \multicolumn{2}{|c|}{$\begin{array}{l}\text { Sacramento River at } \\
\text { Iron Canyon, near } \\
\text { Red Bluff, Cal. }\end{array}$} & \multicolumn{2}{|c|}{$\begin{array}{c}\text { Stony Creek at Julians, } \\
\text { Cal. }\end{array}$} & \multicolumn{2}{|c|}{$\begin{array}{c}\text { Cache Creek at Yolo, } \\
\text { Cal. }\end{array}$} \\
\hline & $\begin{array}{c}\text { Gage } \\
\text { height. }\end{array}$ & Discharge. & $\begin{array}{c}\text { Gage } \\
\text { height. }\end{array}$ & Discharge. & $\begin{array}{c}\text { Gage } \\
\text { height. }\end{array}$ & Discharge. \\
\hline February 24 & $\begin{array}{l}\text { Feet. } \\
19.15\end{array}$ & $\begin{array}{r}\text { Sec. feet. } \\
98,830\end{array}$ & $\begin{array}{l}\text { Feet. } \\
13.50\end{array}$ & $\begin{array}{l}\text { Sec. feet. } \\
22,200\end{array}$ & $\begin{array}{l}\text { Feet. } \\
16.50\end{array}$ & $\begin{array}{l}\text { Sec. feet. } \\
\quad 11,000\end{array}$ \\
\hline February 25 & 19.15 & 98,880 & 10.00 & 7,280 & 7.50 & 3,075 \\
\hline February 26 & 16.80 & 80,760 & 10.00 & 7,280 & 13.00 & 7,700 \\
\hline February $2 \gamma$ & 17.80 & 88,180 & 9.05 & 5,360 & 16.50 & 11,000 \\
\hline February 28 & 12.85 & 54,700 & 7.90 & 3,550 & 9.60 & 4,680 \\
\hline February 29 & 13.40 & 58,000 & 7.40 & 2,900 & 8.60 & 3,900 \\
\hline March 1 & 13.10 & 56,200 & 7.20 & 2,660 & 7.85 & 3,338 \\
\hline March $2 \ldots$ & 15.55 & 71,950 & 7.20 & 2,660 & 7.30 & 2,925 \\
\hline March $3 . .$. & 14.40 & 64,260 & 7.10 & 2,540 & 7.05 & 2,738 \\
\hline March 4 & 15.80 & 73,700 & 7.05 & 2,480 & 6.85 & 2,595 \\
\hline March 5 & 14.70 & 66,220 & 6.75 & 2,145 & 6.65 & 2,455 \\
\hline March 6 & 13.10 & 56,200 & 6.85 & - 2,255 & 6.45 & 2,328 \\
\hline March 7 & 16.30 & 77,200 & 7.55 & 3,085 & 6. 35 & 2,262 \\
\hline March 8 & 24.40 & 147,180 & 7.65 & 3,215 & 6.30 & 2,225 \\
\hline March 9 & 18.95 & 97,200 & 7.25 & 2,720 & 6. 20 & 2,160 \\
\hline March $10 \ldots$ & 17.80 & 88,940 & 13.25 & 20,700 & 14.75 & 9,275 \\
\hline March 11 & 15.80 & 73,700 & 9.25 & 5,720 & 20.75 & 15,250 \\
\hline March 12 & 14. 70 & 66,220 & 7.85 & 3,480 & 12.00 & 6,800 \\
\hline $\operatorname{March} 13$ & 13.30 & 57,400 & 7.35 & 2,840 & 10.75 & 5,675 \\
\hline March 14 & 15.80 & 73,700 & 8.65 & 4,680 & 10.60 & 5.540 \\
\hline March 15 & 17.25 & 84,050 & 8.00 & 3,690 & 10.50 & 5,450 \\
\hline March 16 & 18.30 & 92,040 & 7.60 & 3,150 & 10.40 & 5,360 \\
\hline March $17 \ldots$ & $(18.85)$ & 96,400 & 10.50 & 8,560 & 11.65 & 6,485 \\
\hline March 18 & 19.40 & 100,880 & 9.75 & 6.700 & 16.50 & 11,000 \\
\hline March 19 & 18.30 & 92,040 & 8.85 & 5,015 & 11.75 & 6,575 \\
\hline March 20 & 19.40 & $100 ; 880$ & 8.90 & 5,100 & 10.55 & 5,495 \\
\hline $\operatorname{March} 21 \ldots$ & 16.20 & 76,500 & 8.00 & 3,690 & 10.25 & 5,225 \\
\hline March 22, & 13.50 & 58.600 & 7.45 & 2,960 & 10.10 & 5,090 \\
\hline March 23 & 12.40 & 52,020 & 7.20 & 2,660 & 11.00 & 5,900 \\
\hline March 24 & 11.50 & 46,900 & 6.95 & 2,365 & 9.80 & 4,840 \\
\hline March 25 & 10.40 & 41,100 & 6.80 & 2,200 & 9.80 & 4,840 \\
\hline March 26 & 8.80 & 33,380 & 6.65 & 2,035 & 9.65 & 4,720 \\
\hline March 27 & 11.50 & 46,900 & 8.35 & 4,205 & 9.50 & 4,600 \\
\hline March $28 \ldots$ & 14.70 & 66,220 & 10.50 & 8,560 & 16.75 & 11,250 \\
\hline March 29 & 18.20 & 91,260 & 9.35 & 5,905 & 14.50 & 9,050 \\
\hline March 30 & 14.80 & 66,880 & 8.55 & 4,520 & 11.70 & 6,530 \\
\hline March $31 \ldots$ & 13.00 & 55,610 & 7.30 & 2,780 & 10.40 & 5,360 \\
\hline
\end{tabular}


Daily mean gage height and discharge in Sacramento basin, February 11-March 31,1904 -Continued.

\begin{tabular}{|c|c|c|c|c|c|c|}
\hline \multirow{2}{*}{ Date. } & \multicolumn{2}{|c|}{$\begin{array}{c}\text { Feather River at Oro- } \\
\text { ville, Cal. }\end{array}$} & \multicolumn{2}{|c|}{$\begin{array}{c}\text { Yuba River at Smarts- } \\
\text { ville, Cal. }\end{array}$} & \multicolumn{2}{|c|}{$\begin{array}{l}\text { Mountain and foothill } \\
\text { drainage area, 22,487 } \\
\text { square miles. }\end{array}$} \\
\hline & $\begin{array}{l}\text { Gage } \\
\text { height. }\end{array}$ & Discharge. & $\begin{array}{c}\text { Gage } \\
\text { height. }\end{array}$ & Discharge. & $\begin{array}{l}\text { Estimated } \\
\text { discharge. }\end{array}$ & $\begin{array}{l}\text { Run-off per } \\
\text { square mile. }\end{array}$ \\
\hline February 11 & $\begin{array}{l}\text { Feet. } \\
\quad 3.25\end{array}$ & $\begin{array}{l}\text { Sec. feet. } \\
\quad 3,150\end{array}$ & $\begin{array}{l}\text { Feet. } \\
\quad 5.70\end{array}$ & $\begin{array}{r}\text { Sec. feet. } \\
1,880\end{array}$ & $\begin{array}{l}\text { Sec. feet. } \\
22,408\end{array}$ & $\begin{array}{r}\text { Sec. feet. } \\
1.01\end{array}$ \\
\hline February 12 & 9.00 & 12,900 & 10.50 & 12,340 & 95,554 & 4.29 \\
\hline February 13 & 7.15 & 8,550 & 8.50 & 6,740 & 68,231 & 3.06 \\
\hline February 14 & 5.95 & 6,680 & 7.50 & 4,550 & 51,587 & 2.32 \\
\hline February 15 & 11.65 & 23,250 & 9.50 & 9,350 & 180,369 & 8.09 \\
\hline February 16 & 20.35 & 94,000 & 20.00 & 58,000 & 570,014 & 25.58 \\
\hline February 17 & 16.75 & 59,975 & $(17.00)$ & 41,000 & 298,266 & 13.38 \\
\hline February 18 & 11.85 & 24,250 & $(12.00)$ & 17,880 & 147,436 & 6.61 \\
\hline February 19 & 10.45 & 17,900 & $(10.50)$ & 12,340 & 110,214 & 4.94 \\
\hline February 20 & 9.55 & 14,575 & $(9.50)$ & 9,350 & 94,682 & 4.25 \\
\hline February 21 & 9.65 & 14,925 & $(9.50)$ & 9,350 & $118,07 \%$ & 5.30 \\
\hline February 22 & 17.80 & 69,300 & 20.30 & 59,800 & 442,141 & 19.84 \\
\hline February 23 & 16.40 & 57,000 & 14.30 & 27,660 & 279,554 & 12.54 \\
\hline February 24 & 21.50 & 105,500 & 20.30 & 59,800 & 542,216 & 24.33 \\
\hline February 25 & 18.70 & 77,750 & 13.50 & 24,080 & 328,167 & 14.72 \\
\hline February 26 & 17.15 & 63,450 & 12.40 & 19,480 & 277,421 & 12.45 \\
\hline February 27 & 16.05 & 54,025 & 11.20 & 14,800 & 251,436 & 11.28 \\
\hline February 28 & 13.90 & 37,400 & 10.60 & 12,680 & 169,296 & 7.60 \\
\hline February 29 & 12.55 & 28,400 & 10.30 & 11,700 & 152,750 & 6.85 \\
\hline March 1 & 11.65 & 23,250 & 10.00 & 10,780 & 138,296 & 6.20 \\
\hline March 2 & 11.95 & 24,800 & 9.60 & 9,630 & 152,558 & 6.84 \\
\hline March 3 & 12.15 & 26,000 & 10.00 & 10,780 & 149,724 & 6.72 \\
\hline March 4 & 13.05 & 31,450 & 10.90 & 13,720 & 174,889 & 7.85 \\
\hline March 5 . & 12.55 & 28,400 & 10.90 & 13,720 & 162,746 & 7.30 \\
\hline March 6 & 12.00 & 25,100 & 10.20 & 11,380 & 139,488 & 6. 26 \\
\hline March 7 & 12.05 & 25,400 & 10.60 & 12,680 & 168,548 & 7.56 \\
\hline March $8 \ldots$ & 15.35 & 48,400 & 12.50 & 19,880 & 295,970 & 13.28 \\
\hline March $9 \ldots$ & 14.70 & 43,350 & 11.10 & 14,440 & 217,998 & 9.78 \\
\hline March 10 & 15.65 & 50,800 & 13.10 & 22,380 & 345,474 & 15.50 \\
\hline March 11 & 14.30 & 40,350 & 11.10 & 14,440 & 218,318 & 9.80 \\
\hline March 12 . & 12.35 & $2 \pi, 200$ & 10.50 & 12,340 & 165,973 & 7.45 \\
\hline March 13 . & 11.95 & 24,800 & 9.80 & 10,200 & 143,209 & 6.42 \\
\hline March 14 & 11.85 & 24,250 & 10.70 & 13,020 & 174,824 & 7.84 \\
\hline March $15 \ldots$ & 12.20 & 26,300 & 10.60 & 12,680 & 182,462 & 8.19 \\
\hline March 16 & 11.75 & 23,750 & 10.50 & 12,340 & 183,153 & 8.22 \\
\hline March $17 \ldots \ldots$ & 15.80 & 52,000 & 14.80 & 30,040 & 308,023 & 13.82 \\
\hline March 18 & 20.45 & 95,000 & 15.50 & 33,500 & 380,434 & 17.07 \\
\hline
\end{tabular}

NoTE.-Gage heights in parentheses are estimated, 
Daily mean gage height and discharge in Sacramento basin, February 11-March 31, 1904-Continued.

\begin{tabular}{|c|c|c|c|c|c|c|}
\hline \multirow{2}{*}{ Date. } & \multicolumn{2}{|c|}{$\begin{array}{l}\text { Feather River at Oro- } \\
\text { ville, Cal. }\end{array}$} & \multicolumn{2}{|c|}{$\begin{array}{l}\text { Yuba River at Smarts- } \\
\text { ville, Cal. }\end{array}$} & \multicolumn{2}{|c|}{$\begin{array}{l}\text { Mountain and foothill } \\
\text { drainage area, } 22,487 \\
\text { square miles. }\end{array}$} \\
\hline & $\begin{array}{c}\text { Gage } \\
\text { height. }\end{array}$ & Discharge. & $\begin{array}{c}\text { Gage } \\
\text { height. }\end{array}$ & Discharge. & $\begin{array}{l}\text { Estimated } \\
\text { discharge. }\end{array}$ & $\begin{array}{l}\text { Run-off per } \\
\text { square mile. }\end{array}$ \\
\hline March 19 & $\begin{array}{l}\text { Feet. } \\
19.75\end{array}$ & $\begin{array}{r}\text { Sec. feet. } \\
88,000\end{array}$ & $\begin{array}{l}\text { Feet. } \\
15.10\end{array}$ & $\begin{array}{l}\text { Sec. feet. } \\
\mathbf{3 1}, \mathbf{5 0 0}\end{array}$ & $\begin{array}{l}\text { Sec. feet. } \\
349,319\end{array}$ & $\begin{array}{r}\text { Sec. feet. } \\
15.68\end{array}$ \\
\hline March 20 & 19.15 & 82,000 & 13.30 & 23,220 & 323,675 & 14.52 \\
\hline March 21 & 16. 70 & 59,550 & 10.80 & 13,360 & 228,171 & 10.24 \\
\hline March 22 & 14.70 & 43,350 & 10.30 & 11,700 & 177,349 & 7.96 \\
\hline March 23 & 13.55 & 34,950 & 9.10 & 8,260 & 148,569 & 6.67 \\
\hline March 24 & 12.80 & 29,900 & 9.30 & 8,800 & 134,910 & 6.05 \\
\hline March 25 & 12.00 & 25,100 & 9.10 & 8,260 & 119,151 & 5.35 \\
\hline March 26 & 11.65 & 23,250 & 8.70 & 7,230 & 104,825 & 4.70 \\
\hline March 27 & 11.50 & 22,500 & 9.00 & 8,000 & 128,408 & 5.76 \\
\hline March 28 & 13.75 & 36,350 & 14.80 & 30,040 & 260,514 & 11.69 \\
\hline March 29 & 16. 70 & 59,550 & 13.30 & 23,220 & 287,075 & 12.88 \\
\hline March 30 & 15.10 & 46,400 & 11.10 & 14,440 & 206,309 & 9.26 \\
\hline March 31 & 13.40 & 33,900 & 10.20 & 11,380 & 158,823 & 7.13 \\
\hline
\end{tabular}

The total discharge from the mountain and foothill area was a maximum on February 16, the estimated mean daily rate of discharge being about 575,000 second-feet, or 25.58 second-feet per square mile. This flood rose very rapidly and also subsided rapidly. Four days after the maximum stage was reached the discharge was only 94,680 second-feet. The river at this time again rose very rapidly, and in two days a rate of 442,140 second-feet was attained. The greatest daily rate of discharge in March was on the 18 th, when it was 380,436 second-feet.

By comparing the daily rate of discharge at the gaging stations it is seen that when the rate of flow from the whole mountain and foothill area is a maximum the rate at each of the stations is generally a maximum, but that occasionally the rate at one of the stations is a maximum while the rate from the total drainage basin is not a maximum. For example, the rate of discharge from the total mountain and foothill area was a maximum on March 10, but the rate at Red Bluff was a maximum on March 8.

Taking the rise that culminated on February 16 as a typical one, we may say that 2.8 per cent of the total run-off from the mountain and foothill area came from Stony Creek, 2 per cent from Cache Creek, 16.5 per cent from Feather River, 10.2 per cent from Yuba River, 32.2 per cent from Sacramento River above Red Bluff, and 36.3 
per cent from the mountain and foothill area of the Sacramento basin not included in the areas gaged.

\section{OBSTRUCTION OF CHANNGL.}

The lower Sacramento has always been subject to overflow. The greatest recorded flood was in 1862. The precipitation at Sacramento for December, 1861, and January, 1862, during this flood, was 23.62 inches, while the precipitation for these months for $1903-4$, as seen from the table, page 16, was only 1.57 inches. The maximum height attained was not as great as that of the 1904 flood, but the volume of water discharged was much greater. Some of the bottom land has been reclaimed by the construction of levees, so that the flood width of the river has been considerably reduced. The depths of the channels have been reduced also by the deposit of débris from hydraulic mining on the tributaries.

The reclamation of bottom lands along the river by the construction of levees was begun in $1852^{a}$ and has gone on steadily since that time. It is estimated that $\$ 20,000,000$ has been spent by private parties, reclamation districts, the State of California, and the Federal Government in the reclamation of these lands and in correcting the channels of Sacramento and San Joaquin rivers. The levees in many districts have been repeatedly overtopped by floods. The problem of reclamation has been rendered more difficult on account of the fact that the beds of the streams in Sacramento Valley, particularly the Yuba, Bear, Feather, American, and the Sacramento below the mouth of the Feather, have been raised by the accumulation of débris brought down during floods. Some lands that were formerly exempt from overflow have been inundated recently by the accumulation of mining débris.

\section{DAMAGE DONE BY FEOOD.}

This ftood swept away levees, fences, buildings, crops, and caused great damage to agricultural land. Approximately 800,000 acres of land were flooded. It is said that 50,000 acres of wheat were destroyed by breaks in the levees below. Colusa. Orchards which had reached their most productive age were killed by the water standing upon them. The value of a portion of the submerged land was decreased by having from 2 to 4 feet of sand deposited upon it. On February 26 the levee on the left bank of Sacramento River broke at a point $2 \frac{1}{2}$ miles below the south line of the city of Sacramento. This was known as the Edwards break. The water escaping at this point backed up against the $\mathrm{Y}$ street levee of Sacramento and soon cvertopped the cross levees to the south and reached Sacramento River

${ }^{a}$ Report of the commissioner of public works, 1895. 
by way of Mokelumne River. About 10,000 acres of fertile anc highly cultivated land in the Sacramento flood basin were inundated and remained so until the end of March. This area was planted to crops, orchards, gardens, alfalfa, etc.

The city of Sacramento was surrounded by water on three sides. On March 10 a severe windstorm from the southeast drove the waves against the $Y$ street levee, and a threatened break was prevented only by continuous work.

The Edwards break is supposed to have been caused by the work of squirrels and gophers and the fact that the base of the levee is located upon a bed of quicksand. To this break may be traced the flooding of Staten, Tyler, and Bouldin islands on lower San Joaquin River. Before the repairs were completed the width of the gap in the levee was 1,400 feet and the total cost of closing it has amounted to $\$ 120,000$.

It has been impossible to make a satisfactory estimate of the total damage caused by the flood of 1904 . The most that can be said is that the loss amounted to several millions of dollars. Fortunately, there was no loss of life.

PREVENTION OF FUTURE DAMAGE.

After the flood of February and March, 1904, an engineering cominission was appointed by the governor of California to report upon rectification of Sacramento and San Joaquin rivers and their principal tributaries and the reclamation of overflow lands adjacent thereto. This commission made its report to the commissioner of public works of California, December 13, 1904. It declares that-

In Sacramento Valley and contiguous parts of San Joaquin Valley there are some 1,250 square miles of very fertile land that is subject to overflow from $a$ very considerable flood in Sacramento River, and about 1,700 square miles from ordinary floods. The problem presented for solution is to devise means for preventing the inundation of these lands by having the flood water that must pass through this territory pass harmlessly into Suisun Bay, and to correct the existing faults of the river channel with a view to avoiding the floods and promoting the interests of navigation.

The plans recommended for the solution of the problem are-

1. To conflne the flood waters to the channels of the various streams by means of lerees, so as to prevent destructive inundation of the fertile lands.

2. To correct the alignment of the river by cut-offs where necessary, and to increase its channel capacity by mechanical means where current action fails to accomplish that purpose.

3. To collect the hill drainage, which now loses itself in the basins, in intercepting canals and carry it into the river at selected points.

4. To provide escape ways over levees for surplus flood waters during the period of channel development, and to provide for the disposal of this water in connection with the hill drainage.

5. To provide for the relief of the basins from accumulation of rain and seepage water by means of pumps wherever gravity drainage is not practicable. 
It is proposed to construct lines of levees on both sides of Sacramento River, from Stony Creek on the west and Chico Creek on the east down to its mouth, including both sides of Old River and Steamboat Slough, except where existing levees are adopted into the system. The minimum distance between the levees is specified in each case, and wherever the distance between the present levees is less than this specified amount the width is to be increased, by the removal of the old levee on one or both sides of the river.

The estimated cost of carrying out the plan proposed is $\$ 23,776,000$. The direct benefits to the entire valley to be realized as a result of this plan of improvement are the reclamation of a million acres of extremely fertile land and the placing of all in a position of assured safety from overflow, together with direct and indirect advantages to many associated interests, which, expressed in money valuation, reach at least $\$ 100,000,000$ and assuredly justify the cost of the work.

\section{SUSqUEHANNA RIVER FloOd, PENNSYluaNia.}

By E. C. MứrPH.

From March 3 to 15, 1904, there was a very destructive flood on Susquehanna River, due to excessive precipitation, the rapid melting of ice and snow, and the formation of ice gorges along the river.

FORMER FLOODS.

Destructive floods are not infrequent on this stream, four notable ones having occurred in the past forty years. One of these occurred in March, 1865, and was due to excessive precipitation, accompanied by a rapid melting of ice and snow and the formation of ice gorges. Another occurred in June, 1889, and was due to an excessive and prolonged precipitation, which, in point of volume of water, was the greatest on record. A third occurred in May, 1894, was due to excessive precipitation, and reached a stage from 2 to 3 feet lower than the stage of the 1889 flood at McCalls Ferry. The primary cause of the fourth flood (March, 1904), to be described in this paper, was the breaking up of the ice at places along the stream in January, with the water at so low a stage that this ice instead of moving out of the river collected in places where islands and other obstructions had caused the formation of gorges. These gorges were solidified and increased in thickness by the low temperature of February, forming dams that backed the water, causing overflow of large areas. The warm rains of March 6 and 7 largely increased the volume of flow, causing these gorges to break and form other temporary gorges farther downstream. When these temporary gorges gave way great destruction was caused, bridges, buildings, and even islands being completely destroyed by the action of the ice and water. 


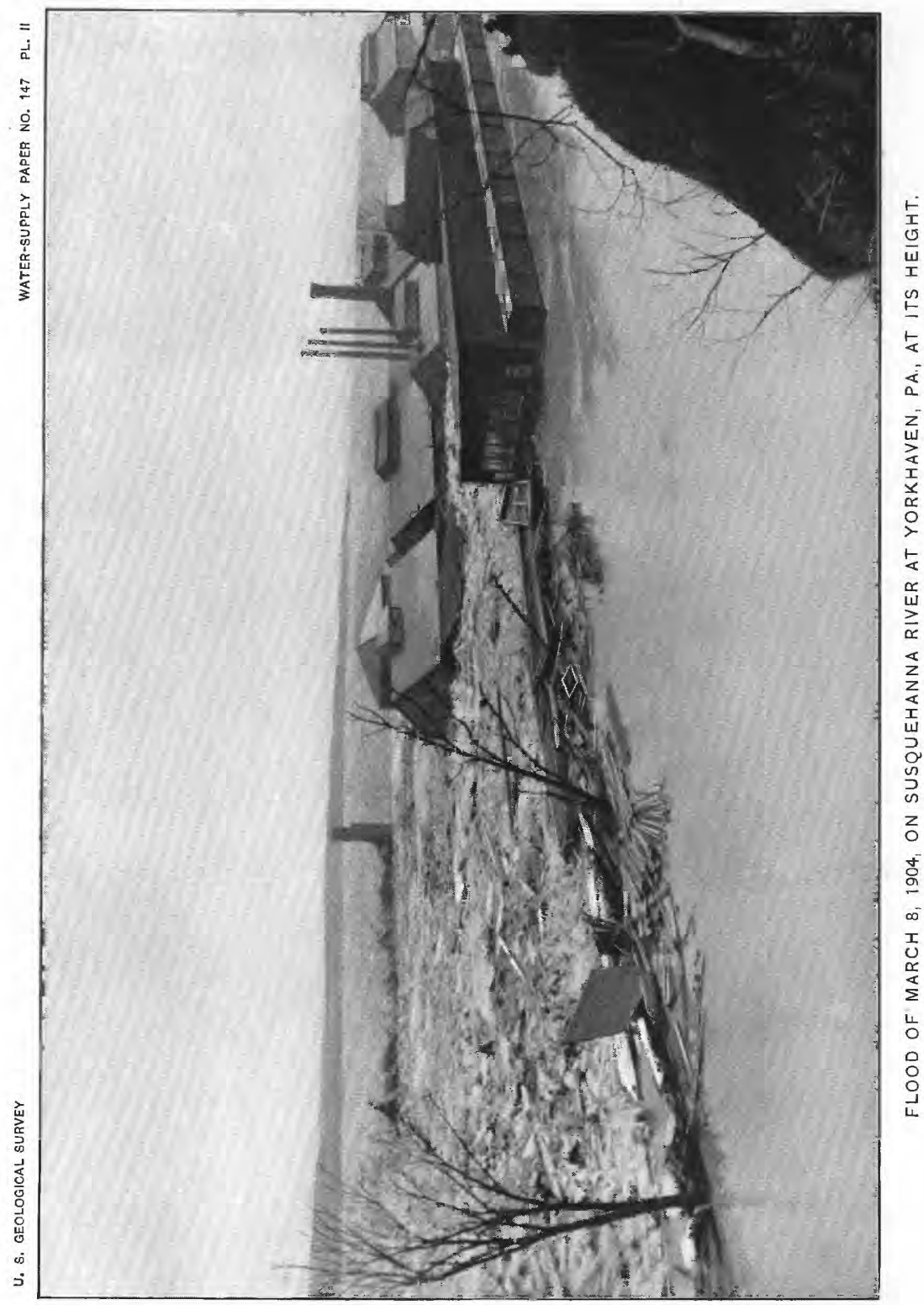


STREAMS AND DRAINAGE BASIN.

The Susquehanna drainage basin is one of the largest on the Atlantic slope and comprises an area of about 27,400 square miles, located mainly in eastern Pennsylvania. About 56 per cent of this basin is in the Allegheny Plateau, 31 per cent in the Allegheny Mountains, 6 per cent in the Allegheny Valley, and 7 per cent in the Pied-

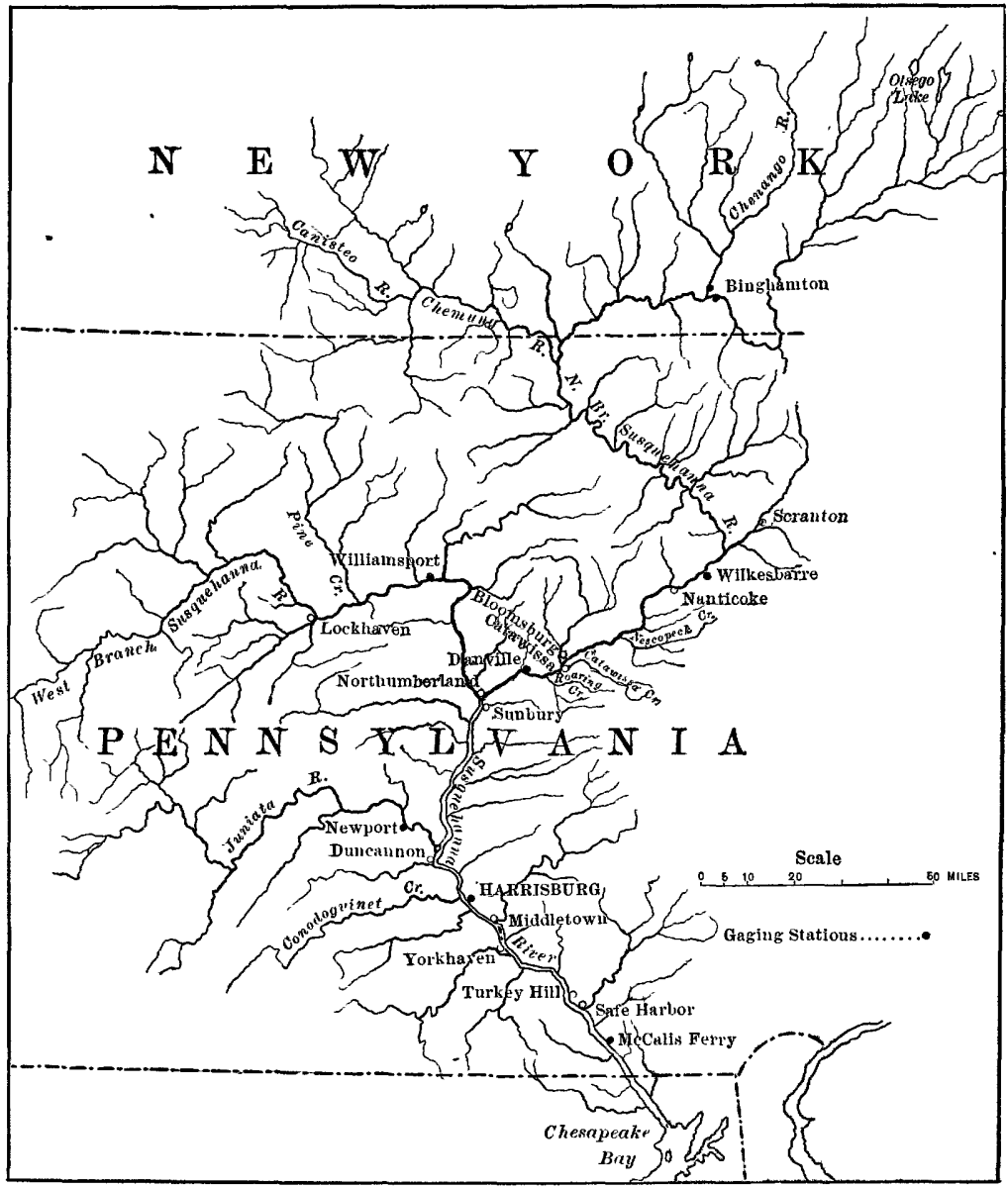

FIG. 1.-Drainage basin of Susquehanna River.

mont Plateau. The Allegheny Plateau is characterized by high hills and deep valleys, the hills rising from about 500 to 800 feet-above the valleys. The western part is more broken and has steeper slopes than the eastern part. The valleys contain much glacial drift and many of the hills are covered with timber. The mountain portion consists of a series of nearly parallel ranges, with steep slopes, through which the Susquehanna has cut its waterway, forming great water 
gaps. Below the mountain region the valleys are wider and the slopes less steep. The slope of the stream is comparatively small in this part of the drainage basin. The Piedmont Plateau region is composed mainly of farming land with low, well-rounded hills and very little forest area. The Susquehanna, like its tributaries in this part of the basin, has a very steep slope for its size, having a number of shoals with considerable fall.

The principal tributaries are Chenango River, which enters from the west at Binghamton, N. Y.; West Branch, entering Sunbury, Pa., and Juniata River, which enters from the west about 15 miles above Harrisburg. (See fig. 1.)

The slope of the river can be seen from the following table:

Profile of susquehunna Ricer:a

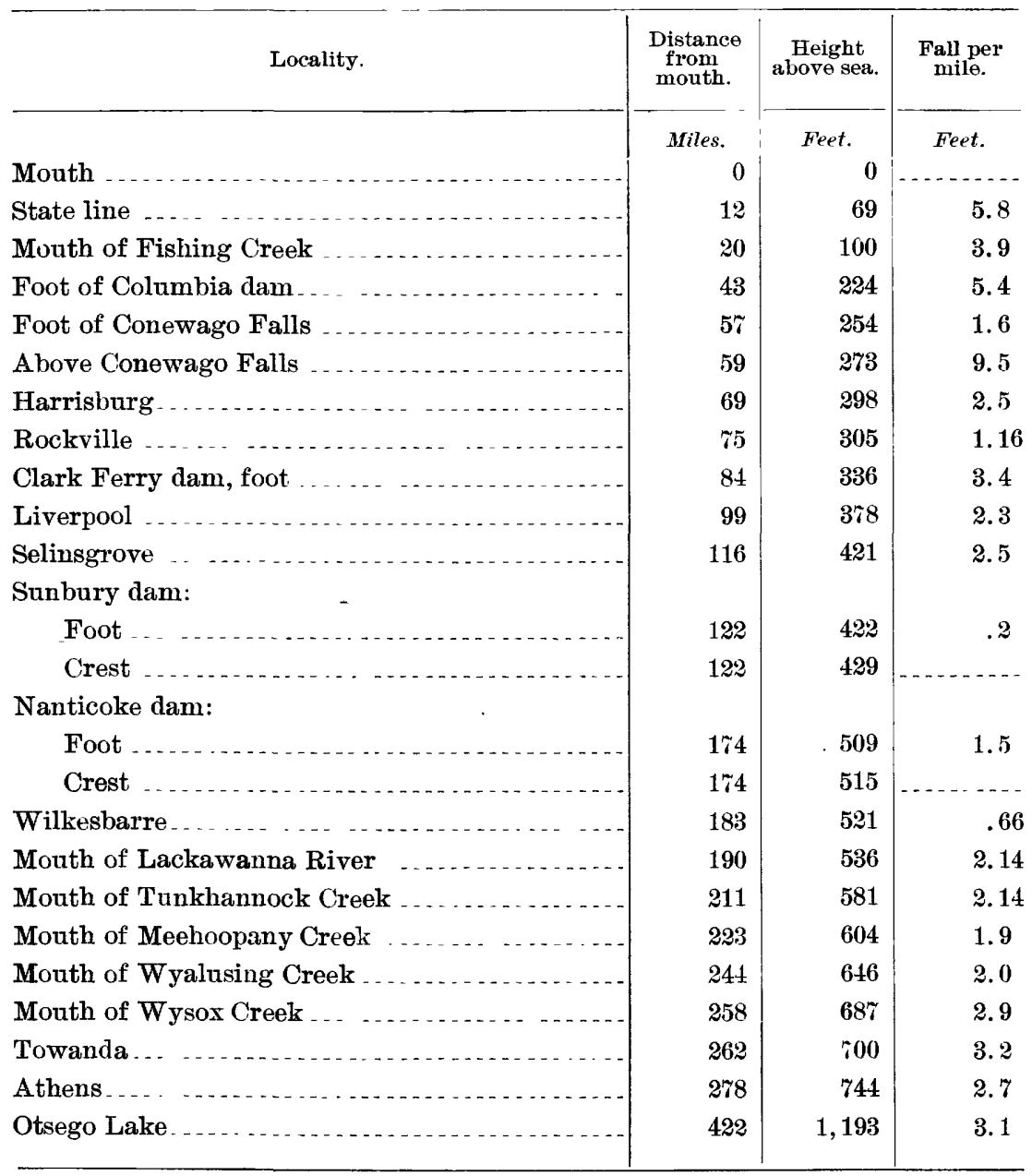

a Gannett, Henry, Profiles of rivers: Water-Sup. and 1rr. Paper No. 44, U. S. Geol. Survey, 1901, p. 17. 


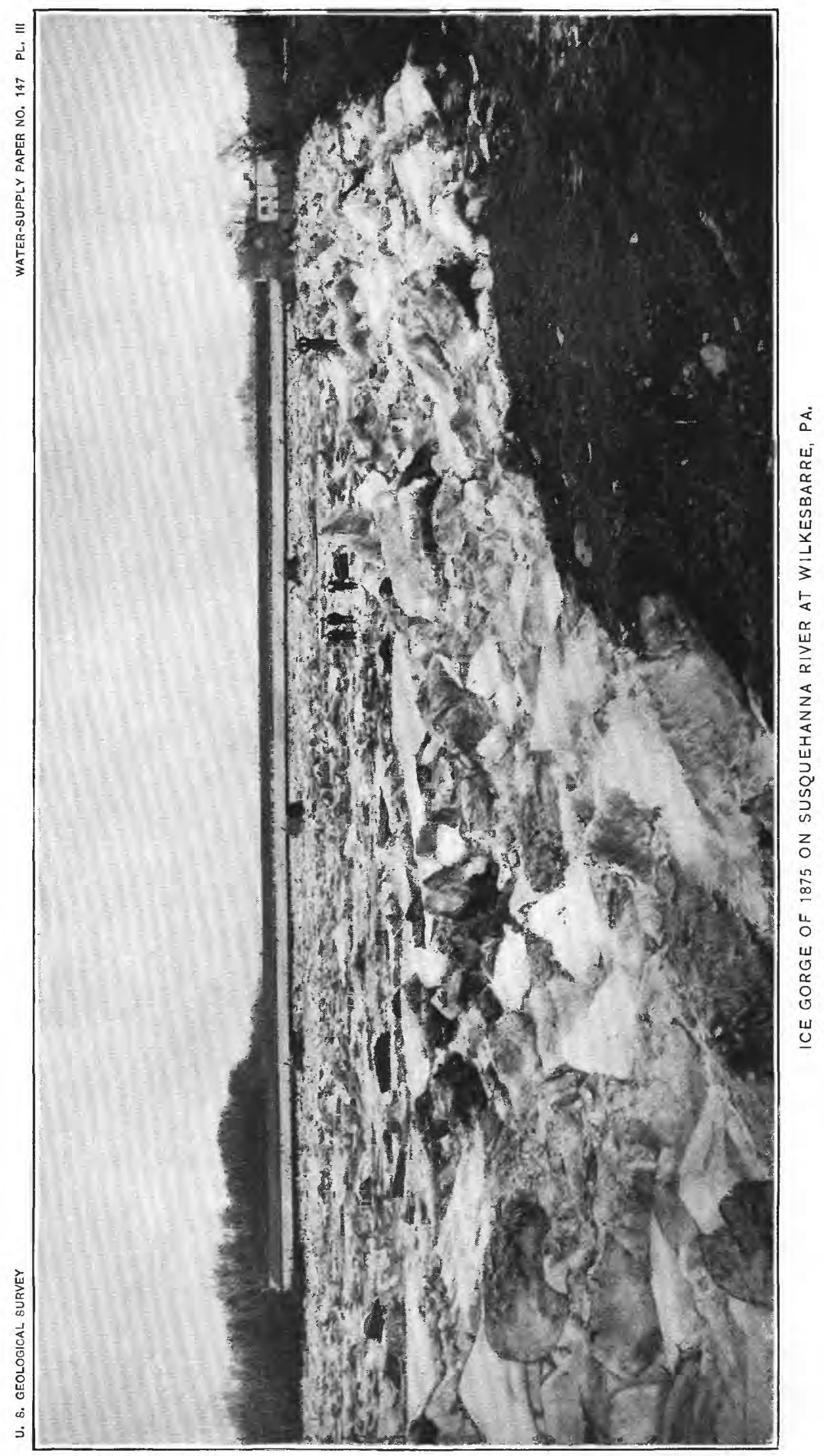




\section{PRECIPITATION.}

The monthly precipitation and the variation from normal monthly precipitation from October, 1903, to March, 1904, at three places in this drainage basin are given below:

Monthly precipitation and monthly variation from normal in Susquehanna basin, 1903-4.

\begin{tabular}{|c|c|c|c|c|c|c|c|}
\hline Place. & Oct. & Nov. & Dec. & Jan. & Feb. & Mar. ' & Total. \\
\hline $\begin{array}{l}\text { Harrisburg, Pa.: } \\
\text { Precipitation }\end{array}$ & $\begin{array}{r}\text { Inches. } \\
2.62\end{array}$ & $\begin{array}{r}\text { Inches. } \\
0.88\end{array}$ & $\begin{array}{r}\text { Inches. } \\
1.92\end{array}$ & $\begin{array}{r}\text { Inches. } \\
3.11\end{array}$ & $\begin{array}{r}\text { Inches. } \\
1.54\end{array}$ & \begin{tabular}{|r} 
Inches. \\
2.72
\end{tabular} & $\begin{array}{l}\text { Inches. } \\
12.79\end{array}$ \\
\hline $\begin{array}{l}\text { Variation } \\
\text { Scranton, Pa.: }\end{array}$ & -.4 & -1.9 & -1.1 & -.5 & -1.4 & -.8 & -6.1 \\
\hline $\begin{array}{l}\text { Precipitation ... } \\
\text { Binghamton, N. Y.: }\end{array}$ & 6.42 & 1.86 & 2.59 & 3.23 & .92 & 2.10 & 17.12 \\
\hline Precipitation & 5.74 & 2.26 & 2.12 & 2.11 & 1.16 & 2.11 & 15.5 \\
\hline Variation & +2.8 & -.1 & -.7 & -.8 & -1.7 & -1.0 & -1.5 \\
\hline
\end{tabular}

From this table it may be seen that there was a deficiency of precipitation at these places of from $1 \frac{1}{2}$ to 6 inches preceding this flood. The deficiency at Binghamton would have been about 3 inches larger had it not been for the excessive precipitation at this place during the month of October.

While these data are not sufficient to enable us to state exactly the deficiency for the whole drainage basin, they are sufficient to indicate that the precipitation over the drainage basin for the six months prior to the flood was below the normal for such a period, and that the flood was not due to the large volume of water flowing, but to the ice gorges in the river.

\section{ICE GORGES.}

The following facts in regard to time of breaking up of ice gorges on this river are taken from the United States Weather Review.

The ice on Juniata River broke the latter part of February and formed a gorge at Duncannon. It broke on West Branch at Lockhaven at $2 \mathrm{p} . \mathrm{m}$. March 3, moving out on a 12 -foot stage. When the Hood reached Duncannon, on March 4, it broke the gorge there and the ice in the river below, destroying Clarks Ferry bridge. The ice began to move at Fort Hunter, 7 miles above Harrisburg, at 10 a. $\mathrm{m}$. 
and at Harrisburg at 10.55 a. $\mathrm{m}$. on March 4 . The surface fluctuations of the river at Harrisburg on March 4 were as follows:

Gage height at Harrisburg, Mareh 4, 1904.

Height in feet.

8 a. $\mathrm{m}$

$12 \mathrm{~m}$

1 p. $\mathrm{m}$

3.15 p. $\mathrm{m}_{-}$

11 p. $\mathrm{m}$

A gorge formed near Middletown, 9 miles below Harrislırg, and another a short distance below Highspire, the water being 1.5 feet higher at the former place and 0.8 foot higher at the latter place than during the great flood of June 2, 1889. All the lowlands along this part of the river were flooded.

There was no material change in conditions on the main stream from March 4 to 8 . The height of the water in the pools above the ice gorges fluctuated as the gorges opened and were closed again by floating ice.

Juniata, West Branch, and the headwaters of the main stream fell from March 4 until the norning of March 7 , when mild weather and rain caused all the branches to rise rapidly. On the evening of March 7 the ice passed out of Roaring, Catawissa, and Nescopeck creeks. Early March 8 the ice began to move at Wilkesbarre, but in two hours formed a gorge and caused the stage to be 29 feet at noon. It broke at Pittston, above Wilkesbarre, about midnight of March 8 , and, moving downstream, lodged on the gorge at Nanticoke, causing the water to reach 30.6 feet at Wilkesbarre, flooding more houses and causing several coal companies to suspend operations. The ice moved about 400 feet at Catawissa at 11.30 on March 9, carrying away two spans of the Catawissa bridge. Several movements of ice occurred in North Branch on March 9, indicating a general breaking up of the ice.

At Middletown at 10 a. m. on March 7 the stage of the river was 34.5 feet-that is, 5 feet higher than during the great flood of June 2, 1889. The gorge at Bainbridge, 14 miles below Harrisburg, moved on March 8, dislodging the gorge at Turkeyhill and forming a gorge below Safe Harbor, submerging the lower part of the town and destroying many houses and two bridges.

The ice started at Danville about $3.30 \mathrm{p} . \mathrm{m}$. on March 9, carrying away the bridge at this place. About $5 \mathrm{p}$. m. it began to move at Wolverton, a few miles above Sunbury, and the portion of the great gorge between Sunbury and Boyds passed out, carrying away three 
spans of the wooden highway bridge at Sunbury. A section of the gorge between Boyds and Rupert moved out at $2 \mathrm{p} . \mathrm{m}$. on March 10, causing the river at Catawissa to fall 14 feet and improving the situation at Bloonsburg, where the water fell at the rate of 6 inches per hour during the afternoon. A section of the gorge at Rupert moved out about noon March 11 without destroying the Bloomsburg Bridge, as it settled back on its piers. The stage at Bloomsburg was 24 feet when the ice began to move, and fell to 12 feet shortly after the movement occurred. The ice was reported to be 6 feet in thickness when it broke up.

No further movement of ice was reported until March 21, when the gorge above Wilkesbarre began to disintegrate and pass downstream. A portion of the gorges in Susquehanna and Chenango Rivers near Binghamton moved out during the afternoon of March 24 . The ice at Bloomsburg, which is near the center of the great gorge, began to move at 7 p. m. on March 24 , and the gorge at Creasy broke at $3.30 \mathrm{p}$. m. on March 25 without doing much damage.

GAGE HEIGHT AND DISCHARGE.

The daily gage height and corresponding discharge at six of the gaging stations in this drainage basin during this flood are given below :

Daily gage height and discharge at gaging stations in Susquehanna drainage basin during flood of March, 1904.

\begin{tabular}{|c|c|c|c|c|c|c|}
\hline \multirow{2}{*}{ Date. } & \multicolumn{2}{|c|}{$\begin{array}{l}\text { Susquehanna River at } \\
\text { McCalls Ferry, Pa. }\end{array}$} & \multicolumn{2}{|c|}{$\begin{array}{l}\text { Susquehanna River at } \\
\text { Harrisburg, Pa. }\end{array}$} & \multicolumn{2}{|c|}{$\begin{array}{l}\text { Susquehanna River at } \\
\text { Wilkesbarre, Pa. }\end{array}$} \\
\hline & $\begin{array}{c}\text { Gage } \\
\text { height. }\end{array}$ & Discharge. & $\underset{\text { height }}{\text { Gage }}$ & Discharge. & $\begin{array}{c}\text { Gage } \\
\text { height. }\end{array}$ & Discharge. \\
\hline March 3 & $\begin{array}{l}\text { Feet. } \\
122.0\end{array}$ & $\begin{array}{r}\text { Sec. feet. } \\
59,000\end{array}$ & $\begin{array}{l}\text { Feet. } \\
11.91\end{array}$ & $\begin{array}{l}\text { Sec. feet. } \\
\quad(a)\end{array}$ & $\begin{array}{l}\text { Feet. } \\
12.3\end{array}$ & $\begin{array}{c}\text { Sec. feet. } \\
\quad(a)\end{array}$ \\
\hline March 4 & 122.9 & 70,200 & 13.50 & $(a)$ & 11.6 & $(a)$ \\
\hline March 5 & 128.0 & 141,100 & 22.00 & $(a)$ & 11.0 & (a) \\
\hline March 6 & 128.0 & 141,100 & 19.41 & $(a)$ & 10.9 & $(a)$ \\
\hline March 7 & 126.0 & 118,500 & 16.33 & $(a)$ & 11.6 & $(a)$ \\
\hline March 8 & 146.6 & 300,000 & 21.16 & (a) & 21.7 & (a) \\
\hline March 9 & 130.2 & 176,500 & 15.91 & $(a)$ & 25.3 & $(a)$ \\
\hline March 10 & 130.4 & 180,700 & 15.00 & $\left({ }^{a}\right)$ & 24.6 & (a) \\
\hline March 11 & 130.9 & 192,000 & 12.00 & $(a)$ & 23.8 & $(a)$ \\
\hline March 12 & 126.6 & 121,300 & 9.16 & $(a)$ & 22.0 & $(a)$ \\
\hline
\end{tabular}


Daily gage height and discharge at gaging stations in Susquehamna drainage basin, ete.-Continued.

\begin{tabular}{|c|c|c|c|c|c|c|}
\hline \multirow{2}{*}{ Date. } & \multicolumn{2}{|c|}{$\begin{array}{l}\text { Susquehanna River at } \\
\text { Binghamton, N. Y. }\end{array}$} & \multicolumn{2}{|c|}{$\begin{array}{l}\text { West Branch at Wil- } \\
\text { liamsport, } \mathrm{Pa} .\end{array}$} & \multicolumn{2}{|c|}{$\begin{array}{l}\text { Juniata River at New- } \\
\text { port, } \mathrm{Pa} \text {. }\end{array}$} \\
\hline & $\begin{array}{c}\text { Gage } \\
\text { height. }\end{array}$ & Discharge. & $\begin{array}{c}\text { Gage } \\
\text { height. }\end{array}$ & Diseharge. & $\begin{array}{c}\text { Gage } \\
\text { height. }\end{array}$ & Discharge. \\
\hline March 3 & $\begin{array}{l}\text { Feet. } \\
\quad 3.92\end{array}$ & $\begin{array}{l}\text { sec. feet. } \\
(a)\end{array}$ & $\begin{array}{l}\text { Feet. } \\
7.5\end{array}$ & $\begin{array}{r}\text { Sec. feet. } \\
26,300\end{array}$ & $\begin{array}{l}\text { Feet. } \\
\qquad 7.2\end{array}$ & $\begin{array}{l}\text { Sec. feet. } \\
16,370\end{array}$ \\
\hline March 4 & 6.65 & $(\alpha)$ & 19.0 & 135,100 & 13.5 & 73,850 \\
\hline March 5 & 8.48 & $(a)$ & 16.5 & 104,300 & 8.9 & 27,700 \\
\hline March 6 & 7.68 & $(a)$ & 9.2 & 37,200 & 6.0 & 9,930 \\
\hline March 7 & 7.52 & $(a)$ & 7.4 & 25,700 & 5.5 & 8,010 \\
\hline March 8 & 11.40 & $(a)$ & 17.4 & 115,000 & 14.0 & 80,100 \\
\hline March 9 & 13.62 & (a) & 13.5 & 72,600 & 10.0 & 36,800 \\
\hline March 10 & 12.25 & $(a)$ & 9.8 & 41,400 & 7.2 & 16,370 \\
\hline March 11 & 9.80 & $(a)$ & 7.6 & 26,900 & 6.0 & 9,930 \\
\hline March 12 & 8.02 & 18,020 & 6.5 & 20,850 & 6.0 & 9,930 \\
\hline
\end{tabular}

a Not computed on account of ice gorge.

The maximum daily gage height attained at the gaging station at Binghamton, N. Y., during this flood is seen from the table above to be 13.6 feet on March 9. This is 4 feet less than the recorded flood of this river at this place, so that the stage was only that of an ordinary flood at this place. Little damage was caused in this part of the drainage basin.

The maximum daily stage attained at the gaging station on the Juniata at Newport is seen from the table above to be 14 feet on March 8. This stream frequently attains a stage of 15 feet or more at this place during floods, so that this flood was of only ordinary magnitude at this place.

At the Williamsport gaging station on West Branch the maximum daily stage was 19 feet on March 4 and 17.4 on March 8. This station has been in operation only about three years, but during this period a maximum stage of 21 feet has been recorded.

The maxinum daily stage reached during this flood at the gaging station at Wilkesbarre was 25.3 feet on March 9. This is 3.5 feet less than that attained by the great flood of 1869 ; the stage on March 9 during the ice gorge was 30.5 feet, however. It is seen from the table that the stage at this place was 23 feet or more for three consecutive days.

At Harrisburg a daily stage of 22 feet was reached on March 5 and 21.2 feet on March 8. Twice in the past thirteen years these stages have been exceeded. On March 29, 1895, it was 25.6 feet, and on March 2, 1902, it was 23.9 feet.

The maximum daily stage at the station at McCalls Ferry during this flood was 146.6 feet on March $\delta$. 
The following table gives the maximum height above low water of 1900 of the flood at five places along the river:

Flood height in 1904, in feet, above low water of September, 1900.a

\begin{tabular}{|c|c|c|c|c|c|}
\hline Date. & $\begin{array}{c}\text { Masin river at } \\
\text { TeCalls } \\
\text { Ferry } \\
\text { (4 p. m. }) .\end{array}$ & $\begin{array}{c}\text { Main river at } \\
\text { Harrisburg } \\
\text { (7a. m.). }\end{array}$ & $\begin{array}{l}\text { North Bpgnch } \\
\text { at Wilkes- } \\
\text { barre (8 a. m.). }\end{array}$ & $\begin{array}{l}\text { West Branch } \\
\text { at Williams- } \\
\text { port (7.30) } \\
\text { a. m.). }\end{array}$ & $\begin{array}{l}\text { Juniata River } \\
\text { at Newport } \\
\text { (12 m.). }\end{array}$ \\
\hline 1904. & & & & & \\
\hline March $3 . .$. & 9.0 & 11.9 & 9.0 & 7.4 & 4.4 \\
\hline March $4 \ldots$ & 9.9 & 13.5 & 11.2 & 18.9 & 10.7 \\
\hline March 5 ... & 15.0 & 22.0 & 16.0 & 16.4 & 6.1 \\
\hline March 6 & 15.0 & 19.4 & 14.9 & 9.1 & 3.2 \\
\hline $\operatorname{March} 7 \ldots$ & 13.4 & 16.3 & 15.4 & 7.3 & 2.7 \\
\hline March $8 \ldots$ & 33.6 & 21.2 & 26.3 & 17.6 & 11.2 \\
\hline $\operatorname{March} 9_{\ldots} \ldots$ & 17.2 & 15.9 & 28.5 & 13.4 & 7.2 \\
\hline March 10 & 17.4 & 15.0 & 24.0 & 9.7 & 4.4 \\
\hline March $11 \ldots$ & 17.9 & 12.0 & 21.9 & 7.5 & 3.2 \\
\hline March 12 & 13.6 & 9.2 & 19.9 & 6.4 & 3.2 \\
\hline $\begin{array}{c}\text { Maximum } \\
\text { height } \\
\text { attained. }\end{array}$ & $b 33.6$ & c 23.3 & $d 28.5$ & e 18.9 & \\
\hline
\end{tabular}

a Hoyt, J. C., and Anderson, R. H., Hydrography of Susquehanna River basin : WaterSup. and Irr. Paper No. 109, U. S. Geol. Survey, 1905.

${ }^{b}$ March 8, 4 p. m.

c March 4,3 p. m.

d March 9,8 a. $\mathrm{m}$.

e March 4, 7 a. m.

NoтE.-Maximum heights other than at McCalls Ferry were caused by backwater from gorges.

The following table gives the maximum, minimum, and mean discharge and corresponding gage height of Susquehanna River at Harrisburg, each year from 1891 to 1904 :

Minimum, maximum, and mean discharge of Susquehama River at Harrisburg, Pa., for 1891 to 1904, inclusive. $a$

\begin{tabular}{|c|c|c|c|c|c|c|c|}
\hline \multirow{2}{*}{ Year. } & \multicolumn{3}{|c|}{ Minimum. } & \multicolumn{3}{|c|}{ Maximum. } & \multirow{2}{*}{$\begin{array}{c}\text { Mean } \\
\text { dis- } \\
\text { charge. }\end{array}$} \\
\hline & Date. & $\begin{array}{c}\text { Gage } \\
\text { height. }\end{array}$ & $\begin{array}{l}\text { Dis- } \\
\text { charge. }\end{array}$ & Date. & $\begin{array}{c}\text { Gage } \\
\text { height. }\end{array}$ & Discharge. & \\
\hline 1891 & $\begin{array}{l}\text { October } 4 \text { to } \pi, \text { in - } \\
\text { clusive. }\end{array}$ & $\begin{array}{c}\text { Feet. } \\
1.60\end{array}$ & $\begin{array}{c}\text { Sec.-ft. } \\
10,200\end{array}$ & February 19 & $\begin{array}{l}\text { Feet. } \\
19.00\end{array}$ & $\begin{array}{l}\text { Sec.-ft. } \\
334,500\end{array}$ & $\begin{array}{l}\text { Sec. } f t . \\
52,200\end{array}$ \\
\hline 1892 & $\begin{array}{l}\text { October } 31 \text { to No- } \\
\text { vember } 8 \text {, in- } \\
\text { clusive. }\end{array}$ & .50 & 4,070 & April 6 . & 14.65 & 224,200 & 37,250 \\
\hline 1893 & $\begin{array}{l}\text { August } 16 \text { to } 19 \\
\text { inclusive, and } \\
\text { August } 25 \text {. }\end{array}$ & .35 & 3,500 & May 6 & 16.50 & 267,400 & 40,550 \\
\hline
\end{tabular}


IInimum, maximum, and mean discharge of susquehanna River, etc.-Cont'd.

\begin{tabular}{|c|c|c|c|c|c|c|c|}
\hline \multirow{2}{*}{ Year. } & \multicolumn{3}{|c|}{ Minimum. } & \multicolumn{3}{|c|}{ Maximum. } & \multirow{2}{*}{$\begin{array}{c}\text { Mean } \\
\text { dis- } \\
\text { charge. }\end{array}$} \\
\hline & Date. & $\begin{array}{c}\text { Gage } \\
\text { height. }\end{array}$ & $\begin{array}{c}\text { Dis- } \\
\text { charge. }\end{array}$ & Date. & $\begin{array}{c}\text { Gage } \\
\text { height. }\end{array}$ & Discharge. & \\
\hline 1894 & September 5 and 6 & $\begin{array}{l}\text { Feet. } \\
.25\end{array}$ & $\begin{array}{r}\text { Sec.-ft. } \\
3,160\end{array}$ & May 22. & $\begin{array}{l}\text { Feet. } \\
25.60\end{array}$ & \begin{tabular}{|l} 
Sec.-ft. \\
543,500
\end{tabular} & $\begin{array}{l}\text { Sec.-ft. } \\
39,970\end{array}$ \\
\hline 1895 & October 30 and 31 & .05 & 2,570 & April 11_ & 13.65 & 205,400 & 29,330 \\
\hline 1896 & September 5 to 13 & .25 & 3,160 & April 1 and 2 & 14.60 & 223,200 & 34,600 \\
\hline 1897 & $\begin{array}{l}\text { September } 15 \text { and } \\
\text { October } 21 \text {. }\end{array}$ & .50 & 4,070 & March 26 & 11.50 & 165,300 & 32,320 \\
\hline 1898 & October 3 to 7 & .65 & 4,740 & March 24 & 15.65 & 245,900 & 40,490 \\
\hline 1899 & October 24 and 25 & .15 & 2,850 & March $\tau_{\ldots}$ & 13.00 & 193,000 & 31,000 \\
\hline $1 \mathrm{C} 00$ & $\begin{array}{l}\text { Septemter } 28 \text { and } \\
\quad 29 .\end{array}$ & -.04 & 2,360 & March $2 \ldots$ & 13.10 & 194,900 & 29,950 \\
\hline 1901 & November $12 \ldots$ & 1.00 & 6,550 & December 16 & 21.40 & 405,100 & 42,380 \\
\hline 1902 & $\begin{array}{l}\text { September } 23,24 \text {, } \\
\text { and } 25 .\end{array}$ & .85 & 5,760 & March 2 & 23.90 & 484,100 & 47,100 \\
\hline 1903 & October $7 \ldots$ & 1.40 & 8,850 & March 2 & 16.85 & 276,500 & 54,510 \\
\hline \multirow[t]{2}{*}{1904} & December $11 \ldots$ & .84 & 5,708 & May $22 \ldots$ & & & 32,318 \\
\hline & $\begin{array}{l}\text { For the } 14 \\
\text { years. }\end{array}$ & $a_{--} .04$ & $a 2,360$ & & b 25.60 & 5543,500 & 39,360 \\
\hline
\end{tabular}

a September 28 and $29,1900$.

$b$ May $22,1894$.

The flood at McCalls Ferry reached a maximum at about $3.30 \mathrm{p.m}$. on March 8, for a stage of 161.3 feet above sea level near the cable on the Lancaster side, and 159.8 feet on the York side. In about half an hour the stage had fallen from 2 to 3 feet, and on the morning of March 9 it had fallen to 15 feet below maximum stage.

A discharge measurement was made at the cable during maximum stage by Mr. R. H. Anderson. The time of the passage of cakes of ice between two cables across the river 80 feet apart was observed at various places across the stream, and the surface velocity computed. From the surface velocity and cross section the discharge was computed and found to be about 631,000 cubic feet per second.

There are several high-water marks of the flood of 1889 along the railway and canal near McCalls Ferry, made by eyewitnesses of that flood. These marks were connected by level, and the slope of the surface obtained. Ten sections were selected, and their area and wetted perimeter measured. From these data and a value of $n$, the coefficient of roughness $(0.05)$, the maximum discharge at these 10 stations was found by Kutter's formula to vary from 713,000 to 780,000 cubic feet per second, the mean of the 10 discharges being 730,000 cubic feet per second. The value of $n$, the coefficient of roughness, was computed from current-meter measurements of discharge at this place at a lower stage. 
It is almost impossible to estimate the damage caused by this flood on Susquehanna River. The estimates made by the newspapers vary all the way from $\$ 2,000,000$ to $\$ 8,000,000$. The greatest loss probably occurred from Wilkesbarre to Sunbury, Pa. The big gorges at Keppsrun, Catawissa, and Nanticoke caused the submergence of large areas of lowland along the river. Kingston, Nanticoke, Dorranceton, Plymouth, Pittston, and other places along the river were partly under water. Many people were compelled to leave their homes, into which the water poured, filling cellars and in some cases the first story of the houses. Blocks of ice floated down, carrying away fences and porches and crashing into houses and causing much damage. The basements in many of the business houses were flooded, and goods damaged or destroyed. The railway tracks along the river were under water in many places, and the depots flooded. Great masses of ice, that required thousands of workmen to remove, were piled on the tracks. Several bridges across the river were destroyed or badly damaged. The Catawissa Bridge had three spans carried away. The Pennsylvania Railroad temporary bridge at Sunbury was destroyed. The Bandville highway bridge was destroyed, and the electric light and coke plant at that place was forced to suspend work. The highway bridge at Sunbury and that at Northumberland were partly destroyed. The highway bridge over Catawissa Creek and several other similar structures were destroyed or badly damaged.

The following is a rough estimate of the damage due to the flood as given in newspaper reports:

Damage from flood of 1904.

Pottstown to Sunbury $a$ $\$ 6,500,000$

Dauphin County $b$ 275,000

Lancaster County 275,000

York County $\mathrm{c}$ 200,000

Cumberland County 200,000

Perry County 200,000

Snyder County 125,000

Juniata County 100,000

Maryland County 100,000

Total

$\tau, 975,000$

The loss and damage to State bridges was reported as $\$ 800,000$.

$a$ of which $\$ 1,000,000$ to $\$ 2,000,000$ were in Wyoming Valley.

Loss at Middletown about $\$ 100,000$.

c Most of the damage occurred at Yorkhaven and vicinity. 
PREVENTION OF FUTURE DAMAGE.

This flood was not due to the large volume of water flowing in the river, but to ice gorges in it. The precipitation for the six months prior to the flood was below the normal, and the melting of snow was not excessively rapid. The ice in the river broke up in January at a low-river stage, and before the river had time to clear itself the temperature fell and the ice collected, forming gorges at narrow places in the stream, river bends, and islands. Snow, water, and continued low temperature added to the thickness of these ice gorges. When the warm rain of early March melted the snow and increased the volume of flow of the river, these gorges held the water back somewhat like a dam and caused the overflow of lowlands. When the gorges finally gave way they swept away everything in their path-fences, trees, buildings, and even small islands.

There does not appear to be any practicable remedy for floods due to ice gorges on streams. It is almost impossible to keep an open channel during the winter. Explosives have been used to break up an ice gorge, but the stream is frequently blocked for many miles, and if the gorge is broken at one place the ice soon forms at another gorge farther down the stream, especially if the temperature is below freezing. The only remedy is to remove, as far as possible, the causes that stop the movement of the ice.

\section{MOHAWK RIVER FLOOD, NEW YORK. $₫$}

From March 25 to 31, 1904, there occurred a flood on Mohawk River, in New York State, which, while not the largest and most destructive in the recorded history of this stream, was yet sufficiently so to call for the following brief description.

\section{STREAMS AND DRAINAGE BASIN.}

Mohawk River is the chief tributary of Hudson River and drains an area of 3,490 square miles. It rises about 40 miles from the east end of Lake Ontario, in New York State, flows in a general southerly direction a distance of about 140 miles, and empties into the Hudson at Waterford.

Its principal tributaries are East and West Canadian creeks, which enter from the north, and Oriskany and Schoharie creeks, which enter from the south. Reels Creek is a small stream that enters the Mohawk from the north near Utica. Starch Factory Creek is a comparatively small stream that enters from the south near Utica. Sauquoit Creek is a tributary of Starch Factory Creek.

The river valley has generally a width of from 1 to 2 miles, made

a Prepared mainly from data furnished by Robert E. Horton, district hydrographer. 
up of rich alluvial meadow land. At Little Falls it cuts through a gorge whose walls are from 500 to 600 feet high. The country gradually rises from the river valley to the hills, attaining an elevation of several hundred feet above the river. On the north the hills are succeeded by an elevated plateau, having mountain peaks of from 2,500 to 3,000 feet in elevation above sea level. About 20 per cent of the drainage area has an elevation from 100 to 500 feet, 37 per cent from 500 to 1,000 feet, 27 per cent from 1,500 to 2,000 feet, 13 per cent from 2,000 to 2,500 feet, and about 3 per cent above 2,500 feet. The part of the drainage basin north of Mohawk River is thickly forested; that on the south is mainly deforested. The tributaries are all quick filling, having a comparatively steep slope and rapid velocity, with little storage, but enter the main river at points a considerable distance apart. The Erie Canal parallels the river from the mouth to a few miles above Rome, and is supplied from the river and some of its tributaries.

The following table ${ }^{a}$ shows the slope of the river from the mouth to Rome :

Slope of Mohawk River, New York.

\begin{tabular}{|c|c|c|c|}
\hline Locality. & $\begin{array}{l}\text { Distance } \\
\text { from } \\
\text { mouth. }\end{array}$ & $\begin{array}{c}\text { Height } \\
\text { above sea. }\end{array}$ & $\begin{array}{l}\text { Fall per } \\
\text { mile. }\end{array}$ \\
\hline & Miles. & Feet. & Feet. \\
\hline Mouth & 0 & 12 & $\ldots$ \\
\hline Lower aqueduet (fall nearly all at Cohoes) & 4 & 162 & 37.5 \\
\hline Schenectady . . . . . & 19 & 214 & 3.5 \\
\hline Mouth of Schoharie Creek .. . & 42 & 270 & 2.4 \\
\hline Three miles east of Utica $\ldots \ldots$ & 95 & 393 & 2.3 \\
\hline Four miles east of Rome $\ldots$ & 112 & 418 & 1.5 \\
\hline Rome, above feeder dam & 115 & 431 & 4.3 \\
\hline
\end{tabular}

Fig. 2 shows the principal streams of this drainage basin; also the precipitation lines and gaging stations.

\section{PRECIPITATION AND TEMPERATURE.}

From the precipitation lines on fig. 2 it is seen that the mean annual precipitation in this basin varies from about 40 to 55 inches. The precipitation for the six months preceding this flood at four places in the drainage basin is given in the following table, which

a Water-Sup. and Irr. Paper No. 44, U. S. Geol. Survey, 1901, p. 15.

IRR $147-05 \mathrm{M}-3$ 
also gives the monthly excess or deficiency at Albany and the accumulated deficiency there for the period in question:

Precipitation in Mohawo River watershed, Oct., 1903, to Mar., 1904.

\begin{tabular}{|c|c|c|c|c|c|c|c|}
\hline Place. & Oct. & Nov. & Der. & Jan. & Feb. & Mar. & Total. \\
\hline Albany: & Inches. & Inches. & Inches. & Inches. & Inches. & Inches. & Inches. \\
\hline Variation from normal & +2.50 & +1.30 & +1.10 & -0.04 & -1.6 & -0.70 & -2.6 \\
\hline Precipitation & 6.09 & 1.65 & 1.59 & 2.51 & 1.17 & 1.94 & 14.95 \\
\hline Amsterdam & 6.89 & 1.85 & 2.10 & 3.74 & 1.91 & 2.82 & 19.31 \\
\hline Little Falls _ & 7.58 & 2.10 & 2.23 & 2.33 & 2.28 & 3.17 & 19.69 \\
\hline Rome ..... & 7.95 & 3. 11 & 2.98 & 5.27 & 2.55 & 3.68 & 25.54 \\
\hline
\end{tabular}
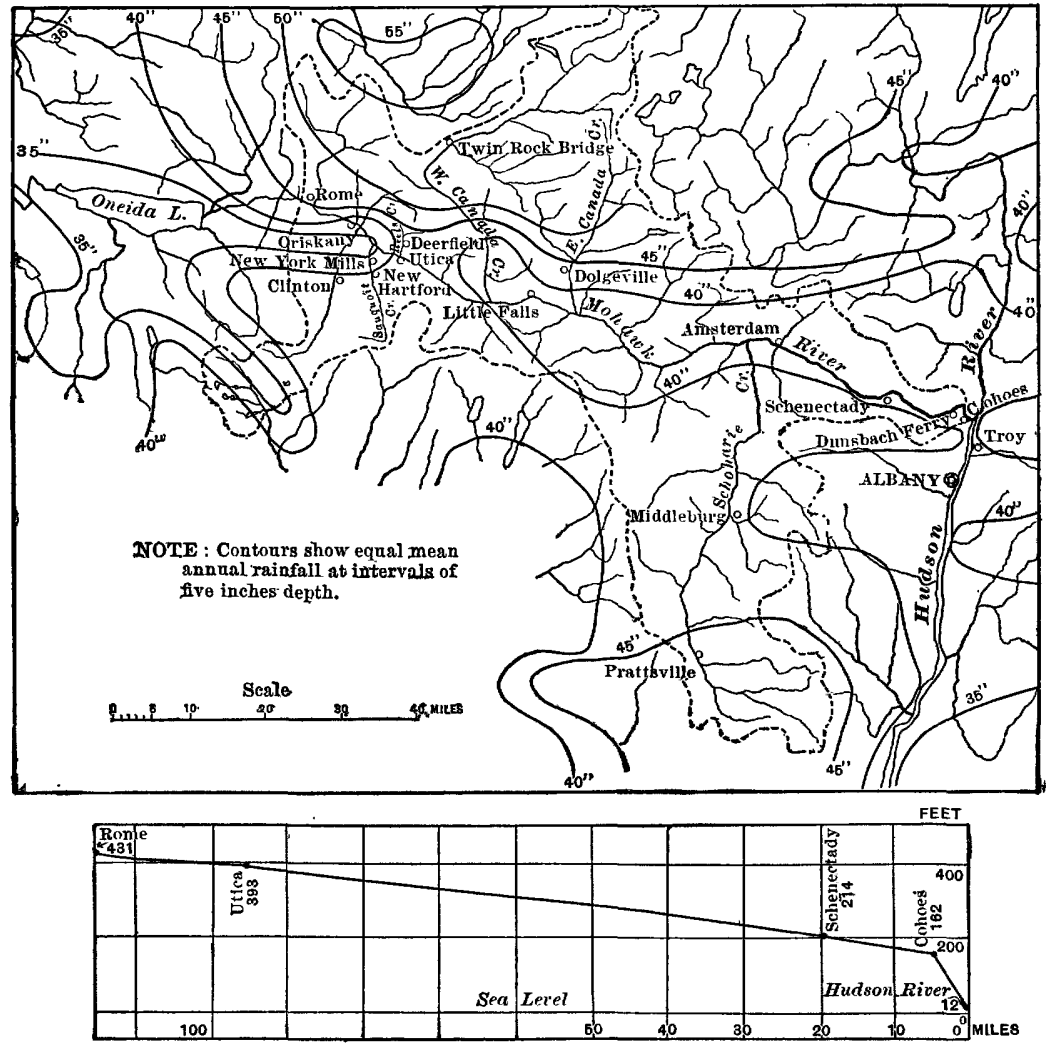

FIG. 2.-Drainage basin and profile of Mohawk River.

It is seen from the table that there is an accumulated deficiency at Albany for the six months of 2.6 inches. The snow accumulation of the winter attained a maximum measured-water equivalent of 
7.42 inches at Utica on March 7 . This gradually decreased to 5.92 inches of water in the form of snow on March 21 .

The temperature and precipitation immediately preceding the flood are shown in the following table:

Precipitation and temperature on Mohawk River watershed, March 22 to $27,1904$.

\begin{tabular}{|c|c|c|c|c|}
\hline \multirow{2}{*}{ Date. } & \multicolumn{2}{|c|}{ Little Falls. } & \multicolumn{2}{|c|}{ Rome. } \\
\hline & Rainfall. & $\begin{array}{l}\text { Mean tem- } \\
\text { perature. }\end{array}$ & Rainfall. & $\begin{array}{l}\text { Mean tem- } \\
\text { perature. }\end{array}$ \\
\hline March $22 \ldots \ldots$ & $\begin{array}{l}\text { Inches. } \\
0.00\end{array}$ & ${ }^{\circ} \mathrm{F}$. & $\begin{array}{l}\text { Inches. } \\
0.30\end{array}$ & $\begin{array}{l}{ }^{\circ} \mathrm{F} . \\
\\
\end{array}$ \\
\hline March $23 \ldots$ & .71 & 38 & .00 & 38 \\
\hline March 24 & .00 & 34 & .00 & 34 \\
\hline March 25 & .35 & $43^{\circ}$ & .20 & 46 \\
\hline $\operatorname{March} 26 \ldots$ & .18 & 42 & .33 & 4 \\
\hline March $27 \ldots$ & .00 & 26 & .00 & 32 \\
\hline Total & 1.24 & & .83 & ......... \\
\hline
\end{tabular}

DISCHARGE.

The rise in temperature on March 25 and 26, as noted above, caused a flood of considerable magnitude owing to the rapid melting of snow, although but little rain fell.

The total discharge and the discharge per square mile of Mohawk River at Little Falls during floods of 1901, 1902, and 1904 are given in the following table:

Flood discharge of Mohawk River at Little Falls, N. Y.

[Drainage area, 1,306 square miles.]

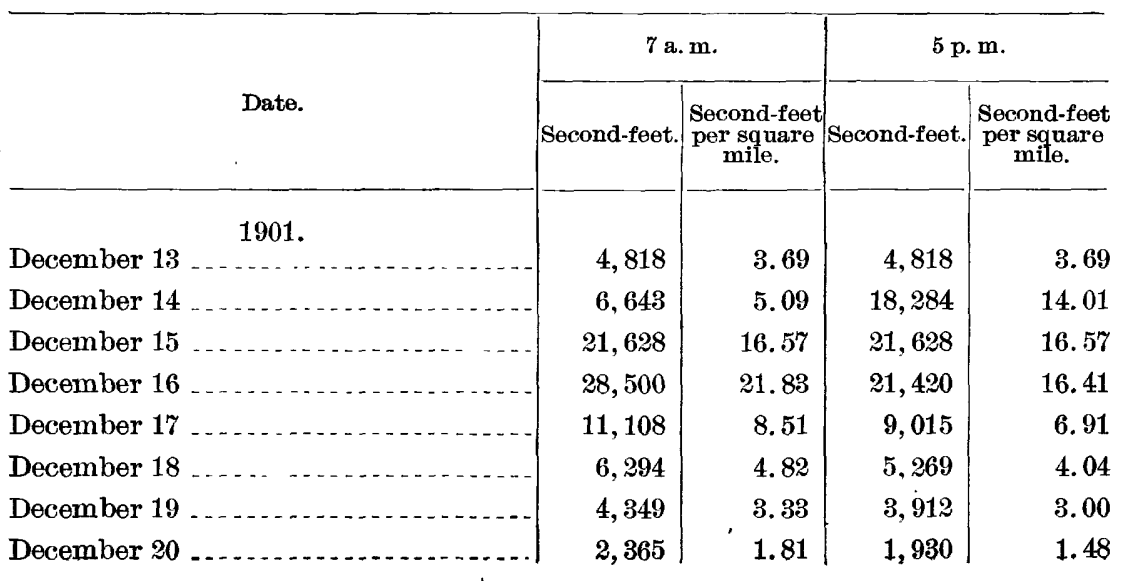


Flood discharge of Hohawh River at Little Falls, N. T.-Continued.

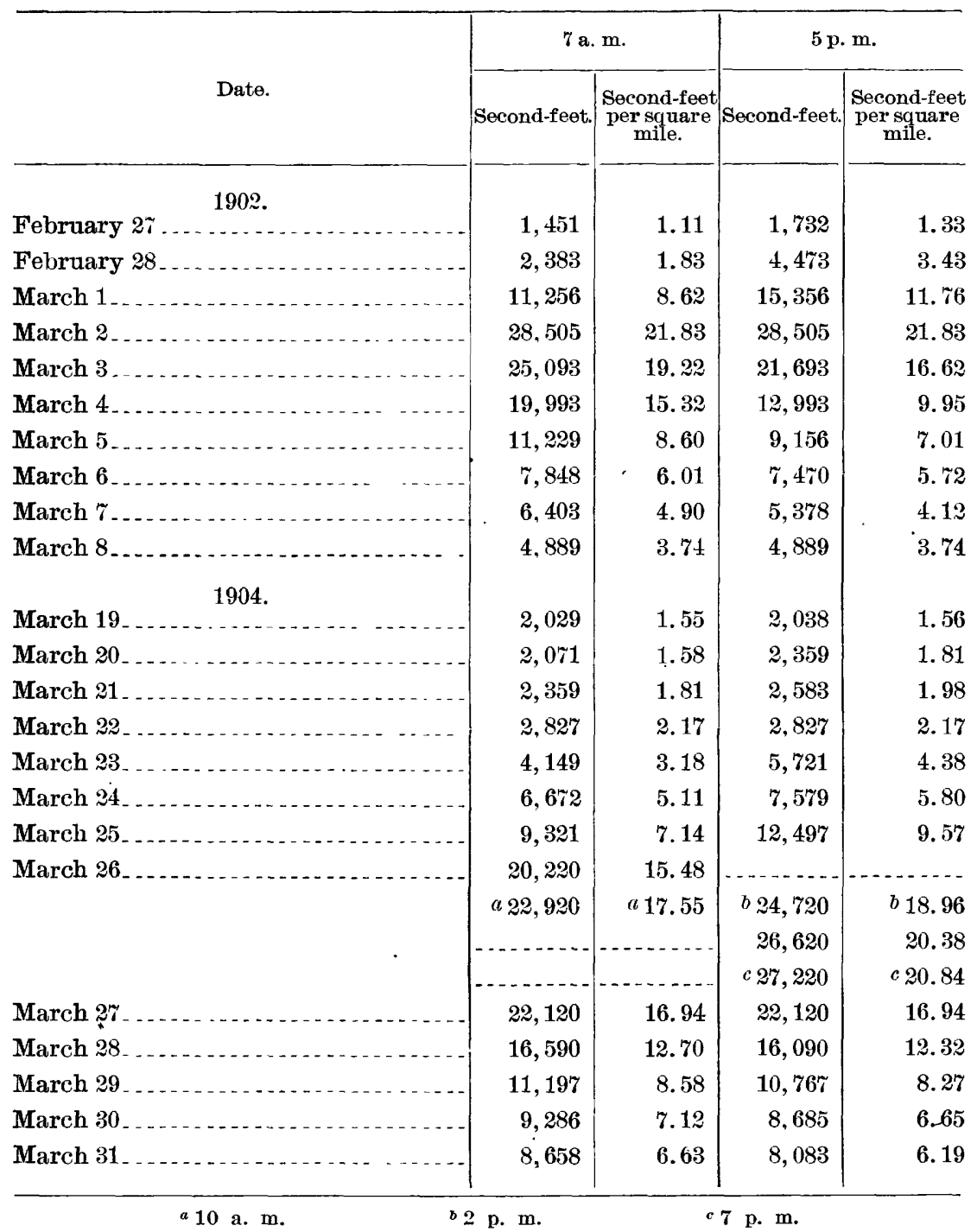

The latest flood lasted from March 25 to 31, attaining a maximum on March 26 of 20.84 cubic feet per second per square mile.

The discharge of three small streams near Utica during this flood are given in the following table: 
Record of flood discharge, 1904.

SYLVAN GLEN CREEK NEAR NEW HARTFORD, N. Y.

[Drainage area, 1.18 square miles.]

\begin{tabular}{|c|c|c|c|}
\hline Date. & Time. & $\begin{array}{l}\text { Second- } \\
\text { feet. }\end{array}$ & $\begin{array}{l}\text { Second-feet } \\
\text { per square } \\
\text { mile. }\end{array}$ \\
\hline \multirow[t]{2}{*}{ March 22. } & 8 a. $\mathrm{m}_{\ldots}$. & 0.357 & 0.302 \\
\hline & 5 p. m... & 2.07 & 1.75 \\
\hline \multirow[t]{3}{*}{ March 23.. } & 8 a. $\mathbf{m}_{\ldots} \ldots$ & 15.24 & 12.87 \\
\hline & 5 p. m... & 14.90 & 12.62 \\
\hline & 8 a. m... & 5.10 & 4.32 \\
\hline March 24 & 5 p. m $\ldots$ & 13.27 & 11.26 \\
\hline \multirow[t]{2}{*}{ March 25} & $\tau .30$ a. $\mathrm{m}$ & 12.33 & 10.42 \\
\hline & 5 p. m $\ldots$ & 66.80 & 56.58 \\
\hline \multirow[t]{2}{*}{ March 26. - } & 8 a. m & 43.06 & 36.51 \\
\hline & 5.30 p. $\mathbf{m}$ & 12.01 & 10.16 \\
\hline \multirow[t]{2}{*}{ March 27.} & 8 a. $\mathrm{m}_{\ldots}$ & 2.67 & 2.26 \\
\hline & 5 p. m $\ldots$ & 1.05 & .889 \\
\hline March 28 & 8 a. m $\ldots$ & 1.05 & .889 \\
\hline
\end{tabular}

STARCH FACTORY CREEK NEAR NEW HARTFORD, N. Y.a

[Drainage area, 3.4 square miles.]

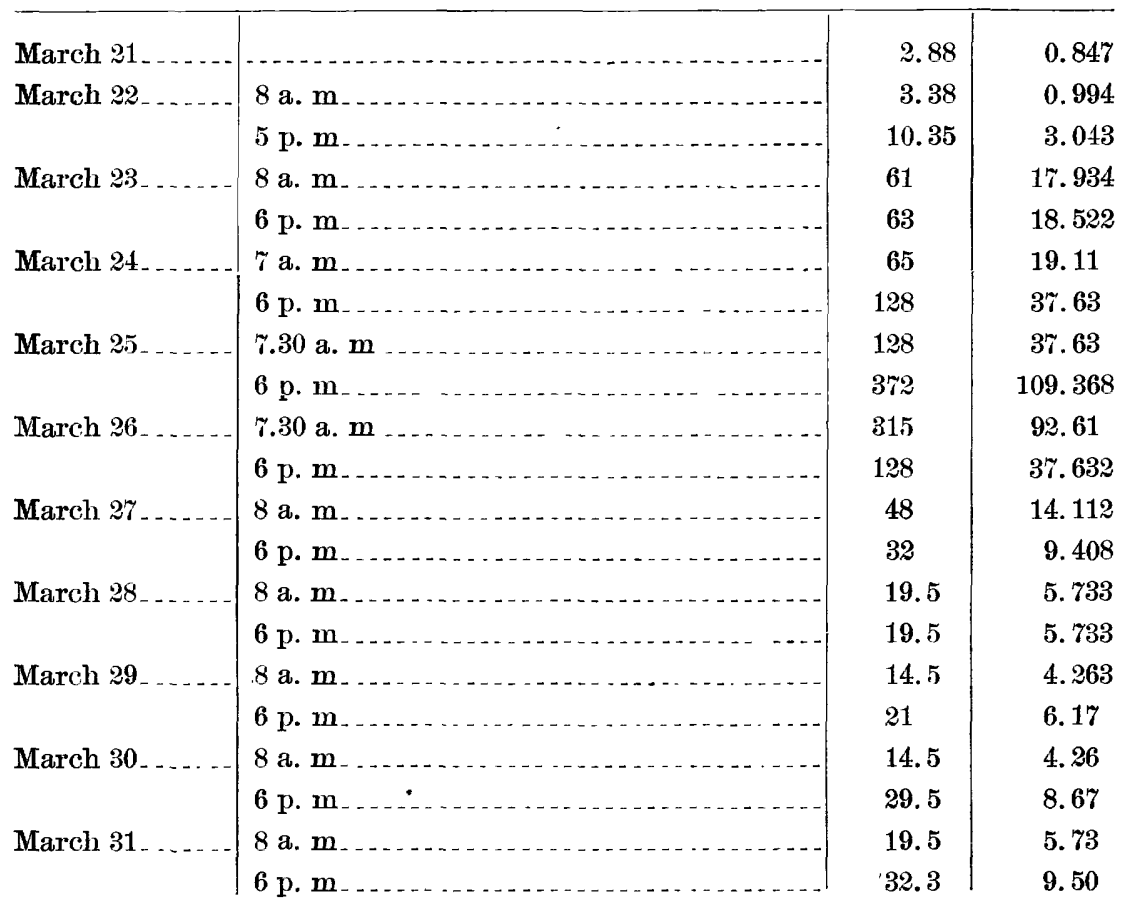
mile. 
Record of flood discharge, 1904-Continued.

STARCH FACTORY CREEK NEAR NEW HARTFORD, N. Y.-Continued.

\begin{tabular}{|c|c|c|c|}
\hline Date. & Time. & $\begin{array}{l}\text { Second- } \\
\text { feet. }\end{array}$ & $\begin{array}{l}\text { Second-feet } \\
\text { persquare } \\
\text { mile. }\end{array}$ \\
\hline \multirow[t]{2}{*}{ April 1. } & 8 a. m & 19.5 & 5.73 \\
\hline & 6 p. m. & 337 & 99.08 \\
\hline \multirow[t]{2}{*}{ April 2} & 7 a. m.... & 40 & 11.76 \\
\hline & $6 \mathrm{p.} \mathrm{m}$ & 48 & 14.11 \\
\hline
\end{tabular}

REELS CREEK AT DEERFIELD, N. Y.

[Drainage area, 4.4 square miles.]

\begin{tabular}{|c|c|c|c|}
\hline March $22_{-}$ & & 8. 72 & 1.97 \\
\hline March $23 \ldots$ & 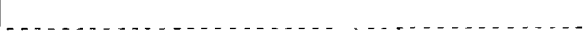 & 24.31 & 5.49 \\
\hline March 24_ & $\ldots$ & 19.43 & 4.38 \\
\hline \multirow[t]{2}{*}{ March 25. ...... } & 7 a. $\mathbf{m}$. & 49.8 & 11.25 \\
\hline & 5 p. m. & 135.9 & 30.74 \\
\hline March $26 \ldots$ & ra. m.... & 179.7 & 40.68 \\
\hline ' & 5 p. m & 214.3 & 48.36 \\
\hline \multirow[t]{2}{*}{ March 27 . } & 7 a. m. & 175.5 & 37.74 \\
\hline & 5 p. m. & 188.5 & 42.6 \\
\hline March 28_ & 7 a. m & 49.9 & 11.28 \\
\hline March 29 & & 33.6 & 7.59 \\
\hline March $30 \ldots \ldots$ & & 30.5 & 6.89 \\
\hline
\end{tabular}

The very large discharge of 109.62 second-feet per square mile of Starch Factory Creek at 6 p. m. on March 25 is worthy of special note.

The following table gives the discharge at maximum stage of the Mohawk and its small tributaries during this flood:

Discharge of Mohawk River and tributaries March 25 and 26, 1904.

\begin{tabular}{|c|c|c|c|c|}
\hline Stream. & Time of maximum. & $\begin{array}{l}\text { Drainage } \\
\text { area in } \\
\text { square } \\
\text { miles. }\end{array}$ & $\begin{array}{c}\text { Maxi- } \\
\text { mum dis- } \\
\text { charge in } \\
\text { second- } \\
\text { feet. }\end{array}$ & $\begin{array}{l}\text { Second- } \\
\text { feet per } \\
\text { square } \\
\text { mile. }\end{array}$ \\
\hline Mohawk River at Rome ${ }^{a} \ldots$ & March 26, p. m . & 158 & 4,320 & 27.34 \\
\hline Oriskany Creek at Oriskany & March 25,5 p. m & 144 & 4,170 & 29 \\
\hline Sauquoit Creek at New York Mills_ & March 26,11 a. m. & 52 & 1,150 & 22.1 \\
\hline Starch Factory Creek near Utica & March 25,6 p. $\mathrm{m}$ & 3.4 & 372 & 109.37 \\
\hline Reels Creek at Deerfield. . & March 26,5 p. $\mathrm{m}$ & 4.42 & 214.3 & 48.36 \\
\hline Sylvan Glen Creek near Utica. & March 25, 5 p. m. & 1.18 & 66.8 & 56.58 \\
\hline Budlong Creek near Utica & March 25, p. m . - & 1.13 & 136.4 & 120.4 \\
\hline Mohawk River at Little Falls _ & March 26, p. m - & 1,306 & 27,200 & 20.8 \\
\hline
\end{tabular}


It is seen that the maximum discharge of the small streams occurred March 25, and the maximum discharge of the main stream did not occur until the evening of the $26 \mathrm{th}$.

The following table gives the discharge of the Mohawk at Little Falls during the floods of February, 1891, December, 1901, March, 1902, and March, 1904:

Flood discharge of Mohawk River in 1891, 1901, 1902, and 1904.

\begin{tabular}{|c|c|c|}
\hline Date. & Second-feet. & $\begin{array}{l}\text { Second-feet } \\
\text { per square } \\
\text { mile. }\end{array}$ \\
\hline February, 1891 & 26,260 & 20.7 \\
\hline December $16,1901 \ldots$ & 26,280 & 20.7 \\
\hline March 2, 1902 $\ldots \ldots$ & $a_{28,500}$ & 20.7 \\
\hline March 26, 1904 $\ldots \ldots$ & 27,200 & 20.8 \\
\hline
\end{tabular}

a Revised computation.

The principal results of the 1901, 1902, and 1904 floods of Mohawk River are summarized in the following table:

Summary of Mohawk River floods of 1901, 1902, and 1904.

\begin{tabular}{r|c|r|r|r|r}
\hline Year. & Period. & $\begin{array}{r}\text { Duration } \\
\text { in hours. }\end{array}$ & $\begin{array}{r}\text { Mean sec- } \\
\text { ond-feet per } \\
\text { square mile. }\end{array}$ & $\begin{array}{r}\text { Mean depth } \\
\text { run-off in } \\
\text { inches. }\end{array}$ & $\begin{array}{r}\text { Total discharge } \\
\text { during flood, } \\
\text { in cubic feet. }\end{array}$ \\
\hline 1901 & December 13 to $20 \ldots \ldots$ & 179 & 8.70 & 2.39 & $7,237,454,976$ \\
1902 & February 27 to March 8. & 224 & 9.18 & 3.19 & $\mathbf{9 , 5 9 1 , 2 6 4 , 0 0 0}$ \\
1904 & March 19 to 31 _..... & 336 & 7.92 & 4.12 & $10,183,289,472$ \\
\hline
\end{tabular}

The results obtained on the small streams near Utica during this flood are summarized in the following table:

Summary of small-streams discharge during flood of 1904.

\begin{tabular}{|c|c|c|c|c|c|c|c|}
\hline \multirow[b]{2}{*}{ Stream. } & \multirow{2}{*}{$\begin{array}{l}\text { Drain- } \\
\text { age } \\
\text { area in } \\
\text { square } \\
\text { miles. }\end{array}$} & \multicolumn{3}{|c|}{ Duration of freshet. } & \multirow{2}{*}{$\begin{array}{c}\text { Aver- } \\
\text { age dis- } \\
\text { charge } \\
\text { in } \\
\text { second- } \\
\text { feet } \\
\text { per } \\
\text { square } \\
\text { mile. }\end{array}$} & \multicolumn{2}{|c|}{$\begin{array}{l}\text { Total yield during } \\
\text { freshet. }\end{array}$} \\
\hline & & From- & To- & Days. & & $\begin{array}{c}\text { Inches } \\
\text { run- } \\
\text { off. }\end{array}$ & Gallons. \\
\hline Starch Factory & 3.40 & $\operatorname{March} 22 \ldots \ldots$ & March $29 \ldots \ldots$ & 7 & 33.33 & 8.67 & $512,278,000$ \\
\hline Reels Creek & 4.42 & March 24, noon & March 29, noon. & 5 & 29.92 & 5.56 & $407,230,000$ \\
\hline Sylvan Glen Creek. & 1.18 & March 22, noon. & March 27, noon- & 5 & 19.06 & 3.55 & $72,570,000$ \\
\hline
\end{tabular}

a Including Uraefenberg diversion. .

The maximum discharge of West Canada Creek during this flood occurred on the afternoon of March 27, and was 7,068 cubic feet per 
second, or 21 cubic-feet per second per square mile, at the gaging station at Twin Rocks Bridge, this being far below the recorded flood maximum of this stream. The cause of this flood of March 26 on the upper Mohawk was apparently the rapid melting of snow on the watershed from Rome to Little Falls, together with ice blockades in the river. A drop in temperature on the 27th checked the rapid melting of snow, and the flood rapidly subsided.

DAMAGE DONE BY FLOOD.

The damage done consisted mainly in the flooding of all lowlands along the river, of cellars, houses, and in some cases the basements of business places; and in the delay or stoppage for a short time of railway traffic on the New York Central Railroad and street railroads of some of the cities along the river. In some places along the river ice gorges formed and flooded large areas. One of these was at Akin. Almost the whole of the village of Fort Hunter was flooded by this ice gorge.

\section{GRAND RIVER FLOOD, MICHIGAN."}

From March 20 to April 8 occurred the largest and most destructive flood in the recorded history of this stream, and in all probability the largest in this drainage basin for a century.

\section{STREAMS AND DRAINAGE BASIN.}

This is the largest river drainage basin in Michigan, comprising an area of 5,570 square miles, draining into Lake Michigan. It is nearly oval in shape, has a length of 135 miles, and a maximum width of 70 miles. It slopes rapidly for about half its length from an elevation along its eastern rim of about 400 feet above Lake Michigan toward the west and toward the river. Its lower half has a very slight slope and contains some flat, highly permeable land with lakes and ponds having no outlets. Fig. 3 shows the stream and its tributaries, the gaging and precipitation stations, and a profile of the river from the mouth to Jackson, a distance of about 210 miles. From the mouth to Ionia, a distance of 81 miles, the average slope is only 0.6 foot per mile. From Ionia to Jackson, 130 miles, the slope is 2.36 feet per mile.

The three principal tributaries above Ionia are Red Cedar, Looking Glass, and Maple rivers, all entering from the east a considerable distance apart. The three principal tributaries that enter below Ionia are the Thornapple from the south and the Flat and Rouge from the north. These three enter within a distance of less than 18 miles, in

a Prepared mainly from data furnished by Robert E. Horton, district hydrographer. 
which the slope is only 0.6 foot per mile; they have a marked effect upon the flood conditions.

\section{PRECIPITATION AND TEMPERATURE.}

The monthly precipitation at five places in this drainage basin for the six months prior to this flood is shown in the following table,

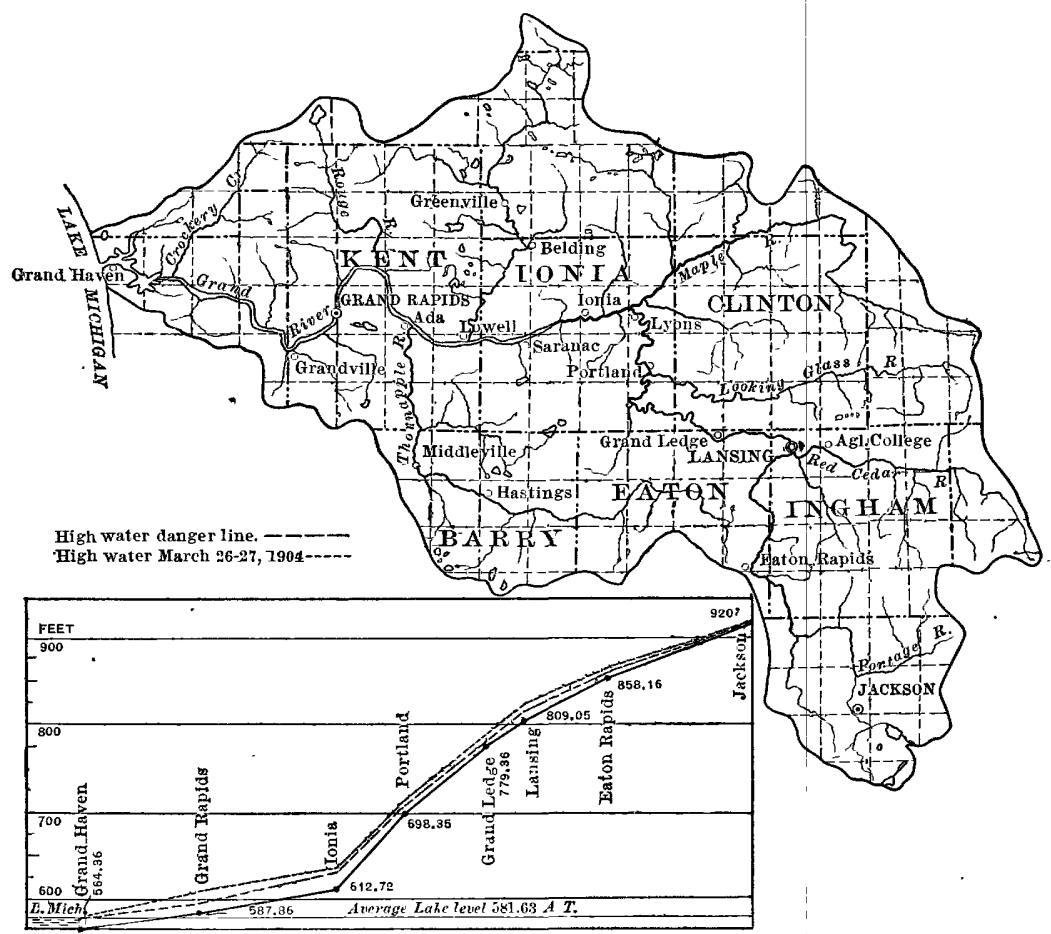

FIG. 3.-Drainage basin and profile of Grand River, Michigan.

as are also the monthly excess or deficiency and the accumulated deficiency at Grand Rapids for the six months:

Precipitation in Grand River basin, October, 1903, to March, 1904.

\begin{tabular}{|c|c|c|c|c|c|c|c|}
\hline Place. & Oct. & Nor. & Dec. & Jan. & Feb. & Mar. & Total. \\
\hline Grand Haven. & $\begin{array}{r}\text { Inches. } \\
1.04\end{array}$ & $\begin{array}{r}\text { Thches. } \\
1.24\end{array}$ & $\begin{array}{r}\text { Inches. } \\
1.31\end{array}$ & $\begin{array}{r}\text { Inches. } \\
0.78\end{array}$ & $\begin{array}{r}\text { Inches. } \\
0.80\end{array}$ & $\begin{array}{r}\text { Inches. } \\
2.16\end{array}$ & $\begin{array}{l}\text { Inches. } \\
7.33\end{array}$ \\
\hline Grand Rapids & $\left\{\begin{array}{r}-.4 \\
2.31\end{array}\right.$ & $\begin{array}{r}-2.6 \\
.85\end{array}$ & $\begin{array}{r}-.6 \\
2.29\end{array}$ & $\begin{array}{r}-1.5 \\
1.47\end{array}$ & $\begin{array}{r}-.8 \\
1.78\end{array}$ & $\begin{array}{r}+2.00 \\
a 4.39\end{array}$ & $\begin{array}{l}-3.9 \\
13.09\end{array}$ \\
\hline Hastings ..... & 1.55 & 1.57 & 1.98 & 2.23 & 1.70 & 5.05 & 14.08 \\
\hline Lansing ........ & 1.99 & 1.45 & 2.06 & 2.82 & 1.53 & $(b)$ & $--\ldots-\ldots$ \\
\hline Jackson ...... & 1. 43 & 1. 43 & 2.07 & 2.80 & $2: 60$ & 3.72 & 14.05 \\
\hline
\end{tabular}

a The depth of snow at Grand Rapids March 20 was 1 inch.

b The depth of snow at Lansing March 6 was 20 inches. 
It is seen that there was an excess of 2 inches in March, but a deficiency of 3.9 inches for the six months October to March. The daily temperature and precipitation during the flood are given in the following table:

Daily precipitation and temperature at Grand Rapids and Lansing, Mich., March 22 to 28,1904 .

\begin{tabular}{|c|c|c|c|c|}
\hline \multirow[b]{2}{*}{ Date. } & \multicolumn{2}{|c|}{ Grand Rapids. } & \multicolumn{2}{|c|}{ Lansing. } \\
\hline & $\begin{array}{c}\text { Precipita- } \\
\text { tion. }\end{array}$ & $\begin{array}{c}\text { Tempera- } \\
\text { ture. }\end{array}$ & $\begin{array}{c}\text { Precipita } \\
\text { tion. }\end{array}$ & $\begin{array}{c}\text { Tempera- } \\
\text { ture }\end{array}$ \\
\hline & Inch. & ${ }^{\circ} \mathrm{F}$. & Inch & ${ }^{\circ} F$. \\
\hline March 22. & 0.43 & 42 & 0.00 & 40 \\
\hline March $23 \ldots$ & .00 & 40 & .00 & 38 \\
\hline March 24 & .00 & 48 & .84 & 46 \\
\hline March $25 \ldots$ & .66 & 45 & .32 & 38 \\
\hline March 26 & T. & 26 & .04 & 21 \\
\hline $\operatorname{March} 27 \ldots$ & $.0 \%$ & 20 & $\mathbf{T}$. & 20 \\
\hline March 28 & T. & 28 & .00 & 28 \\
\hline
\end{tabular}

It is seen that this flood was caused by a moderate rainfall in conjunction with melting snow, due to high temperature.

\section{GAGE HEIGHT AND DISCHARGE.}

The gage height and corresponding discharge at the gaging stations at Grand Rapids and Lansing during this flood are given in the following table:

Mean daily gage height and discharge of Grand River, Michigan, March 20 to April 9, 1904.

\begin{tabular}{|c|c|c|c|c|}
\hline \multirow{2}{*}{ Date. } & \multicolumn{2}{|c|}{ Grand Rapids.a } & \multicolumn{2}{|c|}{ Lansing. } \\
\hline & Gage. & Discharge. & Gage. & Discharge. \\
\hline March $20 \ldots$ & $\begin{array}{l}\text { Feet. } \\
9.20\end{array}$ & $\begin{array}{l}\text { Sec.-ft. } \\
16,700\end{array}$ & Feet. & Sec.-ft. \\
\hline March 21 & 9.30 & 17,000 & 6.60 & 2,840 \\
\hline March 22 & 10.65 & 19,500 & 7.80 & 3,930 \\
\hline March $23 \ldots$ & 11.45 & 21,400 & 11.39 & 9,780 \\
\hline March $24 \ldots \ldots$ & 15.60 & 30,300 & 13.78 & 14,560 \\
\hline March 25 & $\begin{array}{c}18.01 \\
(18.09)\end{array}$ & 35,800 & 16.65 & 20,300 \\
\hline
\end{tabular}


Mean daily gage height and discharge of Grand River, Michigan, March 20 to April 9, 1904-Continued.

\begin{tabular}{|c|c|c|c|c|}
\hline \multirow{2}{*}{ Date. } & \multicolumn{2}{|c|}{ Grand Rapids. } & \multicolumn{2}{|c|}{ Lansing. } \\
\hline & Gage. & Discharge. & Gage. & Discharge. \\
\hline March 26 & $\begin{array}{l}\text { Feet. } \\
(19.05)\end{array}$ & $\begin{array}{c}\text { Sec.-ft. } \\
37,800\end{array}$ & $\begin{array}{l}\text { Feet. } \\
18.02\end{array}$ & $\begin{array}{l}\text { Sec.-ft. } \\
\quad 23,040\end{array}$ \\
\hline March 27 & $\begin{array}{c}19.50 \\
(19.75)\end{array} \mid$ & 39,400 & 16.05 & 19,100 \\
\hline March 28 & $\left.\begin{array}{c}19.20 \\
(19.36)\end{array}\right\}$ & \} 38,500 & 14.05 & 15,100 \\
\hline March 29 & $\left.\begin{array}{c}18.13 \\
(18.22)\end{array}\right\}$ & 36,000 & 12.80 & 12,600 \\
\hline March 30 & $\begin{array}{c}16.75 \\
(16.77)\end{array}$ & \} 32,900 & 10.86 & 8,720 \\
\hline March 31 & 15.40 & 29,900 & 11.07 & 9,140 \\
\hline April 1... & 14.45 & 27,800 & 11.75 & 10,500 \\
\hline April 2. . & 13.80 & 26,800 & 11.40 & 9,800 \\
\hline April 3. . . & 13.80 & 26,600 & 11.10 & 9,200 \\
\hline April 4. & 13.80 & 26,600 & 10.55 & 8,100 \\
\hline April 5... & 12.80 & 24,500 & 8.95 & 6,920 \\
\hline April 6 & 11.20 & 20,700 & 8. 22 & 4,380 \\
\hline April 7. . . & 10.50 & 18,800 & 7.70 & 3,830 \\
\hline April 8....... & 9.55 & 17,400 & 7.38 & 3,520 \\
\hline April 9. & 9.40 & 17,200 & 7.55 & 3,680 \\
\hline
\end{tabular}

Figures in parentheses are elevations corrected for the flow which passed across the west side and entered the river about 1.4 miles below Fulton street; they are used in the volume equivalent.

The flood at Grand Rapids lasted from March 21 to April 8, reaching a maximum on March 27, with a gage height of 19.75 feet and a discharge of 39,400 cubic feet per second, or 8.04 cubic feet per second per square mile. For five days the gage reading was 18 feet or more.

The flood at Lansing reached a maximum on March 26, one day earlier than at Grand Rapids. 'The maximum daily flow at Lansing was 18.7 second-feet per square mile, which is about 2.36 times greater per square mile than that at Grand Rapids, and yet the area overflowed and the damage done by the flood at Grand Rapids was much greater than at Lansing, due to the difference in rapidity of flow.

The flood profile of this river is shown in fig. 3, and the height of the flood above danger line, as shown by gages along the river, is given in the table following. 
Flood profile of Grand River, Hichigan, 1904.

\begin{tabular}{|c|c|c|}
\hline Place. & $\begin{array}{c}\text { Gage } \\
\text { height. }\end{array}$ & $\begin{array}{l}\text { Height } \\
\text { above dan- } \\
\text { ger line. }\end{array}$ \\
\hline Grand Rápids ......... & $\begin{array}{l}\text { Feet. } \\
20.45\end{array}$ & $\begin{array}{l}\text { Feet. } \\
\qquad 9.7\end{array}$ \\
\hline Ionia . . . . & 27.55 & 3 \\
\hline Portland ........ & 14.44 & 2.9 \\
\hline Grandledge $\ldots$ & 14.10 & 7.9 \\
\hline Lansing .......... & 19.45 & 8.6 \\
\hline Eaton Rapids. ....... & 9.20 & 2.7 \\
\hline
\end{tabular}

It is seen that the stage was from 7.9 to 9.7 feet above the danger line at Lansing. Grandledge, and Grand Rapids.

\section{DAMAGE DONE BY FLOOD.}

At Grand Rapids the river began to overflow its banks on the evening of March 24, and the water did not return within the banks of the river until March 31. More than 1,500 houses were flooded, the west part of the city for a width of several blocks being overflowed to a depth in places of 5 feet. The city gas-light plant was cut off by the water and the city was without light for several nights. Ten thousand employees of the various industries along the river were thrown out of work.

The following extract from one of the Bay City, Mich., newspapers describes the flood conditions in Michigan on March 31:

The floods in Michigan are the worst since 1887. Lowlands are everywhere completely under water and roads are in most cases flowing streams.

Numerous dams have been washed out or so badly undermined as to be practically ruined. Bridges, both railroad and highway, are in the same condition. Railroad traffic has been stopped entiręly on account of washouts of bridges or sections of track. Factories have been put out of business by water rising in their basements sufficiently to put out their fires, and several cities are in darkness because of a similar condition of affairs in their lighting-plant power houses.

Stores in the business portion of cities are basement full, and in many cases the water is flowing through them on the ground floors. Many families have been forced to leave their homes.

The damage will be something enormous, both in the actual destruction of property and in the stoppage of business. No figures can be given, but it is conservatively estimated that the loss will run into the millions.

\section{PREVENTION OF FUTURE DAMAGE.}

Destructive floods may occur on this river from the rapid melting of a comparatively small amount of snow, accompanied with a not excessive rainfall, the small slope of bed of the stream from Grand 
Rapids to Lake. Michigan (about 0.6 foot per mile) being insufficient to carry off the water as rapidly as it comes down from the upper watershed. The remedy for the consequent overflow consists in giving the stream an abundant unobstructed waterway and using levees where the benefits derived from them will justify the cost of their construction.

\section{WABASH RIVER FLOOD, INDIANA.}

By F. W. Hanna.

\section{S'TREAMS AND DRAINAGE BASIN.}

The drainage area of Wabash River covers the major portion of the State of Indiana and a considerable territory in eastern Illinois.

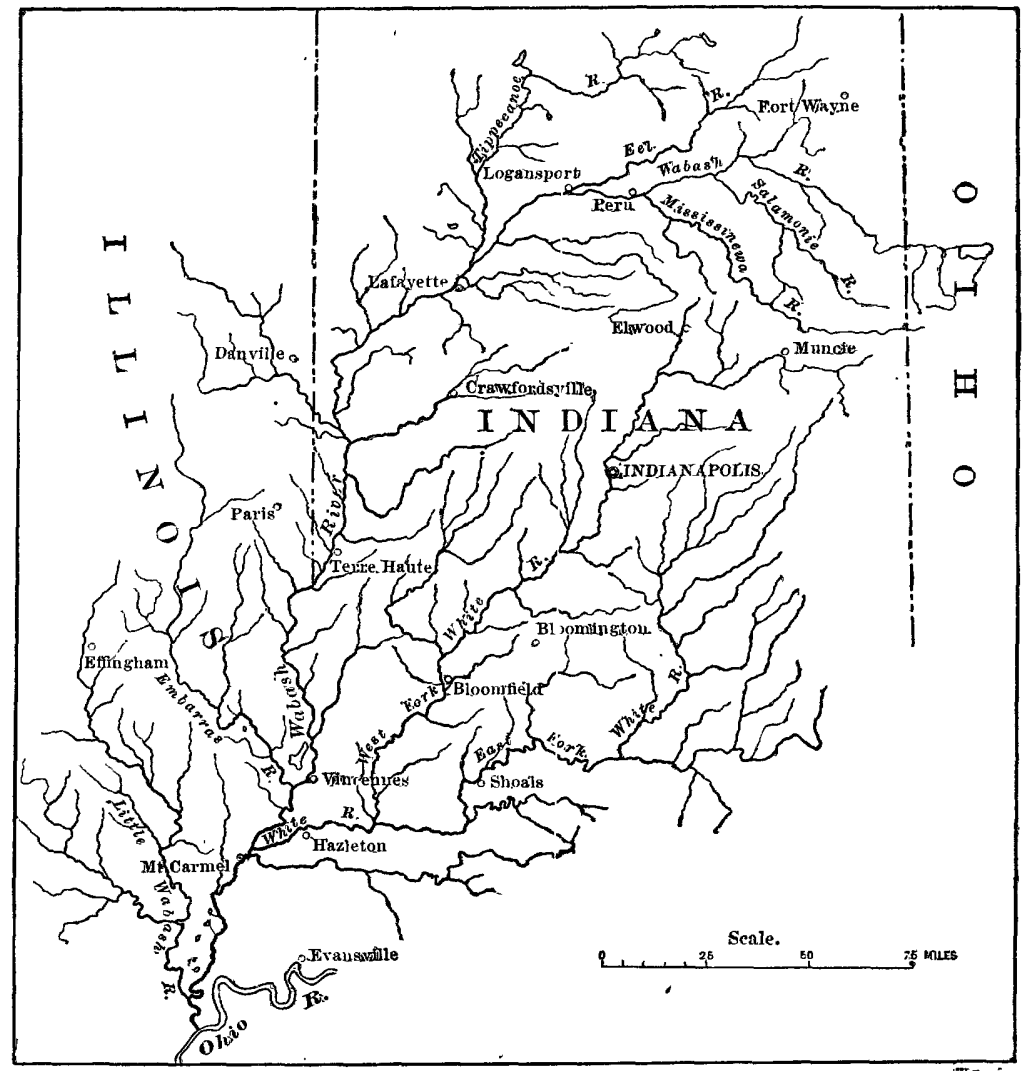

FIG. 4.-Drainage basin of Wabash River.

In shape it resembles a huge fan, the axis of which lies along a straight line connecting its mouth with the town of Wabash, Ind., near its source. In the upper course of the river the right-hand and 
left-hand tributaries are about equally distributed, upper Eel and Tippecanoe rivers being offset by the Salamonie and the Mississinewa. In the lower course of the river the drainage area is unsymmetrical. No important tributaries come in from the right, while on the left it receives the White River system, which comprises a very large portion of the whole drainage area of the Wabash.

The topography of the drainage area is diversified. It belongs chiefly to the topographic classifications of the middle and southern thirds of Indiana, described by Mr. T. C. Hopkins, ${ }^{a}$ who says:

The middle third is somewhat more diversified [than the northern third]. The eastern half of it is a broad, rolling plain area, with no prominent hills nor any very deep valleys. The streams in places run over the surface of the plain and in places are slightly intrenched in it. In the western half of the middle third the streams are more deeply intrenched. The sonthern third, or more, of the State is much more diversified. The area is more deeply trenched by the streams; so much so in places that secondary plains have been formed and the underlying rocks have stamped their character on the surface. The upland sloping plateaus are in many places very much dissected and dirersified by numerous deep valleys cut in them, so that they form a mass of irregular hills.

The total length of Wabash River is 517 miles. Below Lafayette, 312 miles above its mouth, it has an almost uniform fall of 0.6 foot per mile, while the remaining portion above this point has an almost uniform fall of 2.4 feet per mile. The upper tributaries of the river are roughly similar to the upper portion of the main stream, while the lower tributaries are roughly similar to the lower portion.

\section{PRECIPITATION.}

During the major part of March, 1904, considerable rain fell throughout Indiana, causing a rise in the Wabash that reached a maximum stage at Mount Carmel, Ill., on March 14. This stage gradually receded until March 21, when another gradual rise began, caused by precipitation occurring about the middle of the month, and continued by two exceptional storms, one on March 25 and 26 and another on March 31.

On March 22 a storm center was central over the extreme Northwest, which, traveling across the continent at a rate of 34.7 miles per hour, reached the mouth of St. Lawrence River on March 26. This storm center passed over the Wabash drainage area during the latter part of March 25 and the fore part of March 26, traveling practically parallel to the course of the river and precipitating a liberal amount of water over the entire area. In the early morning hours of March 25 the Weather Bureau rain gage at Evansville, Ind., near the mouth of the Wabash, recorded 1.92 inches of precipi- 
tation in five and three-fourths hours, with the excessive maximum fall of 0.55 inch in twenty-five minutes. In the course of about five hours this same storm had reached Indianapolis, Ind., near the headwaters of West Branch of White River, having precipitated copiously over the entire district between Evansville and that point. Here the Weather Bureau rain gage recorded between 7.54 a. m. March 25 and 12.45 a. m. March 26 , a period of about nineteen and one-sixth hours, a total rainfall of 4.72 inches, the maximum being 1.54 inches in one and two-thirds hours. Continuing onward in its northeasterly course, this storm appeared at Cleveland, Ohio, during the evening of March 26, where, however, the amount of precipitation was diminished very materially.

A second storm, originating in the Great Basin on March 28 and traveling across the continent at the average rate of 22.3 miles per hour, reached the mouth of the St. Lawrence on April 2. This storm passed across the Wabash drainage area in a northeasterly course, precipitating heavily upon it throughout its entire course. Near Indianapolis, where the probable maximum intensity was reached, the downpour lasted three hours and five minutes, during which 2.52 inches of rain fell, 1.89 inches of which were precipitated within eighty minutes.

\section{GAGE HEIGHT.}

It will be noted that the total rainfall at Indianapolis during these two storms was 7.24 inches, 3.43 inches of this being precipitated within three hours. The facts that Wabash River and its tributaries were already at a high stage when the storm of March 25 and 26 began, that the comparative rapid fall of the Wabash and its tributaries in its upper course hurried the water from this storm to the lower part of the valley, where it necessarily lingered on account of the low fall of the river, and that another severe storm on March 31 added immense quantities of water which were rapidly carried to the lower valley, all resulted in the greatest flood in height and the longest in duration that has been experienced in the lower valley of the Wabash since the establishment of the Weather Bureau gage on that stream at Mount Carmel, Ill., in 1885, and possibly the largest flood that had occurred in that region for many years before. Only two recorded floods approached anywhere near that of March and April, 1904. In March, 1897, and in March, 1898, the Mount Carmel gage read 26.4 feet and 27.0 feet, respectively. On April 2, 1904 , this same gage recorded 27.1 feet, and would probably have reached 28 feet or higher had not some of the levees in that section given way. Below is appended a list of the maximum stages of Wabash River with their dates of occurrence at Mount Carmel, Ill., is shown by the Weather Bureau records from 1885 to 1904, inclu- 
sive. The zero of this gage is very close to low-water mark for the river at this place.

Maximum yearly gage height on Wabash River at Mlount Carmel, Ill., 1885-1904.

\begin{tabular}{|c|c|c|c|}
\hline Date. & $\begin{array}{c}\text { Gage } \\
\text { height. }\end{array}$ & Date. & $\begin{array}{c}\text { Gage } \\
\text { height. }\end{array}$ \\
\hline January 8,1885 & $\begin{array}{l}\text { Feet. } \\
24.7\end{array}$ & January $25,1895 \ldots$ & $\begin{array}{l}\text { Feet. } \\
\quad 7.5\end{array}$ \\
\hline May $22,1886 \ldots$ & 19.8 & July $29,1896 \ldots$ & 14.3 \\
\hline March $14,1887 \ldots$ & 22.0 & $\operatorname{March} 13,1897 \ldots$ & 26.4 \\
\hline April 5, $1888 \ldots$ & 20.6 & March 30,1898 & 27.0 \\
\hline June 19,1889 & 20.8 & January 23, 1899 & 19.5 \\
\hline January 14,1890 . & 24.1 & March 14, 1900 & 19.0 \\
\hline March $2,1891 \ldots$ & 22.0 & March 19, 1901 ....... & 17.5 \\
\hline April 13, $1892 \ldots$ & 21.5 & December 25, 1902 ........ & 17.0 \\
\hline May $8,1893 \ldots$ & 24.5 & March $12,1903 \ldots$ & 22.3 \\
\hline February $16,1894 \ldots \ldots$ & 13.6 & April $2,1904 \ldots$ & 27.1 \\
\hline
\end{tabular}

The movement of the waters of these successive storms down Wabash and White rivers toward the Ohio can readily ke followed, in a general way, by a study of the gage heights of the United States Geological Survey records at Logansport, Ind., on the Wabash, and at Shoals, Ind., on the east branch of White River, in connection with those of the United States Weather Bureau at Mount Carmel, Ill., on the Wabash, below the White. The zero of the Geological Survey gage at Logansport is about 1 foot below low-water mark, while the zero of the gage at Shoals on White River is about 63 feet below low water. A partial list of the gage heights from March 1 to April 25 is appended below:

Gage height and discharge showing progress of flood at Logansport, shoals, and IIount Carmel, March and April, 1904.

\begin{tabular}{|c|c|c|c|c|c|}
\hline \multirow{2}{*}{ Date. } & \multicolumn{2}{|c|}{ Logansport. } & \multicolumn{2}{|c|}{ Shoals. } & \multirow{2}{*}{$\frac{\begin{array}{c}\text { Mount } \\
\text { Carmel. }\end{array}}{\begin{array}{c}\text { Gage } \\
\text { height. }\end{array}}$} \\
\hline & $\begin{array}{c}\text { Gage } \\
\text { height. }\end{array}$ & Discharge. & $\begin{array}{c}\text { Gage } \\
\text { height. }\end{array}$ & Discharge. & \\
\hline March 1 & $\begin{array}{l}\text { Feet. } \\
\quad 9.90\end{array}$ & $\begin{array}{l}\text { Sec.-ft. } \\
31,710\end{array}$ & $\begin{array}{l}\text { Feet. } \\
67.60\end{array}$ & $\begin{array}{l}\text { Sec.-ft. } \\
8,610\end{array}$ & $\begin{array}{l}\text { Feet. } \\
\quad 10.50\end{array}$ \\
\hline March $21 \ldots$ & 6.20 & 14,880 & $6 \% .70$ & 8,860 & 15.50 \\
\hline March 22 & 8.30 & 24,140 & 68.00 & 9,610 & 15. 70 \\
\hline March 23 . & 8.10 & 23,220 & 74.40 & 25,870 & 16.00 \\
\hline March 24 & 6.68 & 16,940 & 75.20 & 27,950 & 16.50 \\
\hline March 25 . & 6.85 & 17,670 & 78.40 & 36,270 & 17.70 \\
\hline $\operatorname{March} 26$ & 13.45 & 51,980 & 87.10 & 58,880 & 20.70 \\
\hline
\end{tabular}


Gage height and discharge showing progress of flood at Logensport, shoals, and Mount Carmel, March and April, 1904-Continued.

\begin{tabular}{|c|c|c|c|c|c|}
\hline \multirow{2}{*}{ Date. } & \multicolumn{2}{|c|}{ Logansport. } & \multicolumn{2}{|c|}{ Shoals. } & \multirow{2}{*}{$\frac{\begin{array}{c}\text { Mount } \\
\text { Carmel. }\end{array}}{\begin{array}{c}\text { Gage } \\
\text { height. }\end{array}}$} \\
\hline & $\begin{array}{c}\text { Gage } \\
\text { height. }\end{array}$ & Discharge. & $\begin{array}{c}\text { Gage } \\
\text { height. }\end{array}$ & Discharge. & \\
\hline $\begin{array}{c}1904 . \\
\text { March } 27 . \ldots . .6\end{array}$ & $\begin{array}{l}\text { Feet. } \\
14.84\end{array}$ & $\begin{array}{l}\text { Sec. } f t . \\
56,880\end{array}$ & $\begin{array}{l}\text { Feet. } \\
87.70\end{array}$ & $\begin{array}{l}\text { Sec.-ft. } \\
60,450\end{array}$ & $\begin{array}{l}\text { Feet. } \\
\quad 21.90\end{array}$ \\
\hline March 28 & 13.05 & 49,380 & 92.80 & 73,710 & 23.10 \\
\hline March 29 & 10.32 & 33,840 & 95.20 & 79,950 & 24.10 \\
\hline March 30 & 7.50 & 20,520 & 94.90 & 79,170 & 25.50 \\
\hline March 31 & 9.10 & 27,880 & 93.40 & 75,270 & 26.50 \\
\hline April 1 & 12.22 & 43,380 & 91.00 & 69,030 & 27.00 \\
\hline April $2 \ldots$ & 13.00 & 47,130 & 88.80 & 63,310 & 27.10 \\
\hline April 3 ... & 13.10 & 47,630 & 87.20 & 59,150 & 26.60 \\
\hline April 4 & 11.06 & 37,430 & 85.60 & 54,990 & 26.10 \\
\hline April 5 & 7.65 & 21,220 & 84.40 & $51,8 \% 0$ & 25.60 \\
\hline April 6 & 5.73 & 12,940 & 83.40 & 49,270 & 25.30 \\
\hline April 7 & 4.88 & 9,530 & 80.20 & 40,950 & 25.20 \\
\hline April $8 \ldots$ & 4.45 & 8,220 & 73.20 & 22,750 & 25.10 \\
\hline April $9 \ldots$ & 4. 70 & 9,080 & 68.40 & 10,610 & 24.60 \\
\hline April 14. & 3.90 & 6,400 & 66.80 & 6,610 & 20.00 \\
\hline April 25 & 2.60 & 2,770 & 65.20 & 2,820 & 6.70 \\
\hline
\end{tabular}

\section{DAMAGE DONE BY FLOOD.}

It is always very difficult, if not entirely impossible, to determine the damage done by a flood. Inconvenience, suffering, and loss of life all may result from floods, and these are not reducible to mathematical statement. Even the property losses are difficult to estimate, as portions not entirely ruined are so damaged, defaced, or spoiled by water soaking as to take away the joy of their use, if not their practical utility. Various attempts have been made to ascertain the amount of damage wrought by the Wabash flood of 1904, through the estimates of county commissioners, city councils, and railroad officials. In summing up this matter the Indianapolis News of March 29 says:

It is estimated the damage in this county will reach $\$ 2,225,000$ and north of this county an additional $\$ 1,000,000$. Eleven lives have been lost in the Indiana flood so far, and the total property loss in the State has been estimated at from $\$ 8,000,000$ to $\$ 10,000,000$. At Madison the county commissioners estimated the loss to bridges at $\$ 40,000$. In Wabash County the loss is $\$ 50,000$, half of which is in the city. At Peru the loss is $\$ 100,000$. Reports from Seymour say that the loss in that vicinity will be $\$ 35,000$. Reports from Bloomington say that the loss in that county will be $\$ 50,000$, 
This estimate was made before the great flood in the lower Wabash region was creating its greatest havoc with all kinds of property. Railroads, municipalities, highways, farms, in fact every kind of property in reach of the waters-and their reach was high and widesuffered untold damage.

The damage to the railroads throughout the entire State of Indiana, and especially in the southern portion, was very great. Many of the roads on portions of their lines were unable to run trains for nearly a week, some of the small towns not being able either to receive or transmit mail for several days. Trains were detoured by all sorts of means to reach their final destinations, running without any hope of time schedule. Culverts and bridges, not only of railroads, but of highways as well, were swept out by the rush of waters through waterways insufficient at best and made more so by tremendous collections of drift.

The Indianapolis News for March 30 prints the following estimate of damages in Indianapolis to engineering works, principally bridges, prepared by Mr. Juep, city engineer:

Damages to engineering works at Indianapolis, Ind., March, 1904.

Bridges, etc. :

East Tenth Street Bridge

Highland Avenue Bridge

Dorman Street Bridge.

7,000

East Ohio Street Bridge

8,000

Capitol Avenue Bridge and repairs

15,000

East Michigan street repairs

i, 500

Washington Street Bridge, Irvington

2,500

Indiana Avenue Bridge abutments

7,000

Meridian street retaining walls, repairs to Barth Avenue Bridge,

Indiana avenue and cottage avenue retaining walls

5,000

Grand avenue culvert

Repairs to Liberty Street Bridge

Henry Street Bridge

Merrill street retaining walls for sewers

50

Merrill street and Senate avenue bridges

McCarthy Street Bridge

Delaware Street Bridge (new), over Pogues Run

Ray Street Bridge

Additional flood walls for protection of bridges

4,000

Levees and miscellaneous:

Raymond street.

Fall Creek, in five different places

other important improvements and repairs of levees along White

River

Cleaning, scraping and regraveling streets and alleys 
Levees and miscellaneous-Continued.

Providing floodgates for sewers

Repairs to temporary bridges over White River

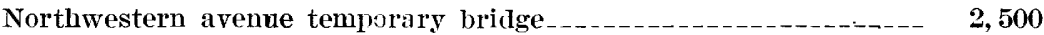

West Tenth Street Bridge

Sewer work and repairs and catch basins

For drainage of flooded districts, cutting levees, and rebuilding

Refilling washouts in streets

Total

168,908

Reports from other parts of the Wabash territory showed that the damage was as great as in the vicinity of Indianapolis. The county commissioners of Daviess County reported 50 bridges damaged and 18 entirely washed away in that county alone. The big steel bridge over White River at Bloomfield was taken out, and large structures at various other places were swept away, crippling wagon, electric, and steam roads relentlessly.

All of the large railroad embankments in the bottom lands of White and Wabash rivers were especial points of attack by the waters. Owing to their obstructing nature, a head of several feet caused such heavy pressure as to start percolation and ultimate disintegration. At Hazleton, on the Evaniston and Terre Haute Railroad, in the lower White River region, the situation was serious. The following extract from the Evansville Courier of April 1 is not only illustrative of this point, but of many others throughout the flooded districts:

Hazleton, Ind., March 31.-Three hundred workmen and four dirt trains are working night and day to save the big fill north of Hazleton. The heavy rain Wednesday night and the continued backing of flood water on the upper side of the embankment forced a stream of water through the fill early Thursday morning. Thirty thousand sand bags had been piled along the track for a mile in anticipation of a break, and the workmen at once began piling them into the crevasse. They were unable to make headway against the wash, and by last night a dozen streams were trickling through the embankment and slowly washing it away.

At a late hour last night the break was reported to be in worse condition than in the morning in spite of all that had been done. The water stands 6 feet higher on the upper side of the embankment than on the lower.

It is probable that more damage was done to the farms and farming interests than to any other class of business or property. Many farms were washed full of ditches; others were covered with several inches or feet of sand, and thousands of acres were flooded. The breaking of many levees throughout the valleys greatly increased the destruction. The following newspaper dispatches give something of an idea of the damage done by this cause:

Vincennes, Ind., March 28.-The Wabash River levee, 10 miles north of here, broke in two places last night, flooding more, than 15,000 acres of the finest land in Knox County. The water rushed through fields, sweeping everything 
before it. The farmers were warned in the afternoon that the levee was weak, and it is believed that no lives were lost. Reports say that houses were swept off their foundations and the loss will amount to thousands. One break was about 75 feet wide; the other was 300 feet wide. Groundhogs or human beings are supposed to have caused the breaks. Other places in the levee are weak, and big damages may come at any time. Farmers say that all the wheat covered by water is killed.-Indianapolis News.

Sullivan, Ind., March 29.-The break in the township levee is now 135 feet wide. Three hundred feet of the Illinois Central tracks to the west of the Riverton Bridge form a dam over which the water is flowing into the bottoms at a rapid rate. Much live stock has been killed.-Evansville Courier.

Clay City, Ind., March 30.--Eel River has been sweeping through its valley in this county, doing much damage to farms and railroads. The $T$-foot levee constructed by the Lewis Township Improvement Company last year at a cost of many thousand dollars to protect farm lands on the west side of " the Big Bend" is said to be ruined, without having afforded any returns for the money and labor it represented. It was proposed to build a similar levee on the opposite side of the stream, but the project has been abandoned.-Indianapolis News.

The breaking of these levees, added to the water already flowing in on unprotected tracts of land, produced extremely disastrous results. Thousands of acres of growing wheat were either partly or totally destroyed. Large amounts of grain and hay in store were either destroyed or carried away. A loss of 20,000 bushels of corn in one township alone was reported. Houses, barns, sheds, farm implements, and live stock were swept away. Fifty head of dead cattle were seen floating in the drift near Mount Carmel.

In addition to the great damages already discussed, every town within the reach of the flood suffered heavy loss. Some of the small towns were entirely drowned out; others were isolated and ran short of provisions; all were partly submerged, cellars were filled with water, merchandise ruined, furniture spoiled, water supplies shut off, light plants closed down, and business completely paralyzed. In the midst of all this many people suffering from disease died from exposure; some were drowned in attempting to escape from the flood; others lost their liyes in trying to save property either of their own or their neighbors; and still others were drowned in heroically attempting to save lives.

\section{PREVENTION OF FUTURE DAMAGE.}

The proper construction of levees is always a matter of vital importance, inasmuch as they invite people to inhabit districts not otherwise tenable and encourage their spending considerable sums of money through the confidence inposed in their protection. It is usually found upon inspection of levees that have failed that a few additional inches in height, a few additional feet in width, a little extra precaution in their protection and care would have enabled 
them to meet the flood crisis efficiently. The recent experience with the levees in Wabash Valley should lead to the rectifying of any such errors as these in that vicinity. Careful inspection should be made for the purpose of locating any and all defects of the above nature and immediate steps taken to repair them. Where there is a State engineer such matters should be under his charge, and recommendations should be made by him. In the cases where burrowing animals are especially bad, or where from any cause percolation is extremely likely to occur, and where the value of the property protected will permit, narrow concrete walls may be used to prevent the digging of holes through the embankment. This method is necessarily very expensive, but there are exceptional cases where the value of the protected property will warrant its use.

The straightening, widening, and deepening of river channels may be made a means of flood prevention. This must be done, however, in such a way as not to harm one portion of the valley by benefiting another. For instance, if all the headwater streams of the river are so improved as to bring the upper flood waters hurriedly down into the lower valley, where neither natural nor artificial means abundantly exist for their disposal, their field of destruction is merely transferred and their power for evil intensified. On the other hand, if a stream is improved in its lower valley or in any portion of its valley where ample drainage is furnished below the improved portion, great benefit must_result.

In the case of the recent Wabash flood the greater part of the destruction took place in the lower valley in and about the junction of White and Wabash rivers. With the exception of a few isolated cases, the water channels in this region were less able to dispose of the water's delivered to them than those in any other portion of the drainage area. Evidently any improvement of the nature under discussion in the upper valleys without a corresponding increase of the carrying capacity of the lower-valley channel would be unwise. If the lower Wabash channel was improved so as to meet the additional demand on it, then the straightening, deepening, widening, and diking of some of the tributaries of this stream would be very beneficial. This is especially true of both branches of White River, which is extremely low banked and winding.

Often serious local flood damage is caused by the narrowing of the river channels by bridge piers, railroad embankments, highway grades, and other obstructions. The natural waterway is reduced for a given stage of water to a half, and often much less, of the original and natural one. The consequence is that the water is backed up several feet and property is seriously inundated that should have been free from the flood. As an instance of this, the situation in the flood 
under discussion on White River at Shoals, Ind., may be cited. The town of Shoals consists of two parts, designated East Shoals and West Shoals. West Shoals is situated on ground on the right side of White River, lying mainly above high-water limit; East Shoals occupies chiefly a high rocky knoll immediately adjacent to the left bank of the stream. This eminence is exceptionally high at its central part next to the river, but slopes off toward low ground in all three of the remaining directions. The ordinary river channel runs adjacent to this bluff and carries stages of 15 to 20 feet of water. When the water gets higher it naturally spreads out over a flat several hundred feet wide on the right side. Still greater elevations of water surface originally caused the water to flow around to the left of the above-mentioned knoll. During the 1904 flood a maximum stage of about 35 feet above low water was reached. Had the riverchannel waterway been what nature had prepared for it, it would have been four or five times as wide and several times as large as it was, and the water would not have risen to any such stage as it did. A highway grade and a railroad embankment made the surplus waterway on the right of the main channel useless, and a railroad embankment also prevented the water from passing around the knoll to the left as it naturally would. The result was that these obstructions served as a dam that raised the water several feet higher than it would naturally have risen. Much property on the lower margins of the knoll was flooded that should have been high and dry. The highway bridge has a length of only 445 feet between abutments, and the railroad bridge, a short distance below, is about the same length, and the maximum discharge of 80,000 second-feet was forced to pass through this space. The capacity of this waterway was also reduced by end contraction on the right bank. It is a notable fact that a high, solid embankment bridge approach on a low flat covered with several feet of water causes an action at the bridge similar to end contraction in a weir.

By obtaining slope, wetted perimeter, coefficient of roughness, and area of waterway the necessary increase in the length of the bridges to enable the channel to carry the flood at this point without causing undue rise might be computed. The computation is not made, as the situation is not critical enough to cause action on the computed results. This special case is cited at length as being one that came under the writer's observation and as being typical of many others throughout the flooded territory. Many instances from various places are reported where the unnatural rise caused by such obstructions as these has been 6 or 7 feet. Very often this rise has resulted in serious damage. Such cases demand the services of an engineer who is capable of determining what may be done to prevent future similar occurrences. 


\section{BELLE FOURCHE RIVER FLOOD, SOUTH DAKOTA.}

During the early part of June, 1904, the northern part of the Black Hills, South Dakota, was visited with excessive rainfall, which caused the Belle forrche and other streams in that region to reach the highest known stage since 1883 and to do much damage to property along their banks.

\section{STREAMS AND DRAINAGE BASIN.}

Belle Fourche River, sometimes called North Fork of Cheyenne

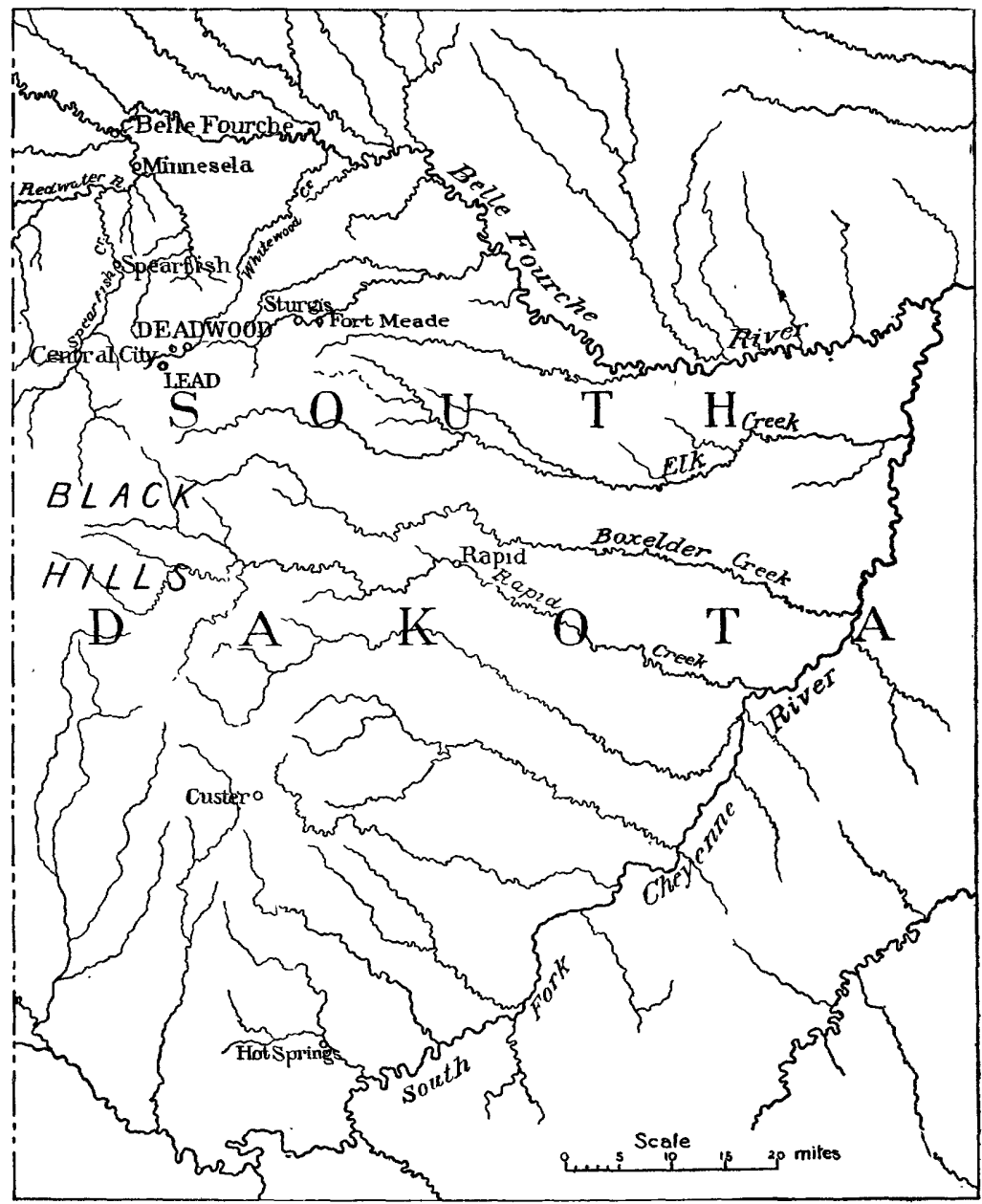

FIG. 5.-Part of Black Hills drainage.

River, rises in the northeastern part of Wyoming and flows in a gen- 
erally southeasterly direction, joining South Fork about 13 miles east of the Dakota-Wyoming boundary line, and is the main run-off stream from the Bear Lodge Mountains. It fluctuates greatly during the year, being often dry during the summer, but after a rain frequently discharging 7,000 to 10,000 second-feet for a short time; it rises and falls very rapidly. Although parts of the watershed of this stream are mountainous and rough, there are no very high mountains. It is barren of timber, except along the streams. The soil is what is locally known as gumbo, a type that sheds water easily and is very little cultivated.

Redwater River is an important tributary of the Belle Fourche, draining a part of the northerm slope of the Black Hills. Spearfish and Sand creeks are its tributaries. Its watershed is mainly rough and broken.

Rapid Creek is the main stream from the eastern part of the Black Hills. It has a steady fall and is never entirely dry. Its basin is mainly in the forest reserve, and its slopes are timbered. These streams are shown in fig. 5 .

\section{PRECIPITATION.}

The rain causing this flood began May 31 and continued more or less steadily until June 4, the greater part of the precipitation falling on June 3 and 4. It was much heavier on the hills than on the plains. The rainfall records of the United States Geological Survey rain gage show 2.70 inches at Belle Fourche from June 1 to 5, and the United States Weather Bureau records show 3.10 inches at Fort Meade and 3.28 inches at Rapid for the same period. In the mountains at Spearfish the precipitation was 5.55 inches, or about double that on the plains for the same period.

\section{GAGE HEIGHT AND DISCHARGE.}

The streams in this region rose steadily and reached a maximum on June 5. The greatest damage was done during the night of June 4 and the morning of June 5 . The duration and magnitude of the flood can be seen from the mean daily gage height and corresponding discharge at the regular gaging stations on Belle Fourche and Redwater rivers and Rapid Creek, as shown in the table following. 
Discharge of Belle Fourche and Redwater rivers and Rapid Creek, June, 1904.

\begin{tabular}{|c|c|c|c|c|c|c|}
\hline \multirow{2}{*}{ Date. } & \multicolumn{2}{|c|}{$\begin{array}{c}\text { Belle Fourche at Belle } \\
\text { Fourche. }\end{array}$} & \multicolumn{2}{|c|}{$\begin{array}{c}\text { Redwater at Belle } \\
\text { Fourche. }\end{array}$} & \multicolumn{2}{|c|}{ Rapid Creek at Rapid. } \\
\hline & $\begin{array}{c}\text { Gage } \\
\text { height. }\end{array}$ & Discharge. & $\begin{array}{c}\text { Gage } \\
\text { height. }\end{array}$ & Discharge. & $\begin{array}{c}\text { Gage } \\
\text { height. }\end{array}$ & Discharge. \\
\hline June 1 & $\begin{array}{l}\text { Feet. } \\
\quad 2.32\end{array}$ & $\begin{array}{r}\text { Sec.feet. } \\
212\end{array}$ & $\begin{array}{l}\text { Feet. } \\
2.95\end{array}$ & $\begin{array}{r}\text { Sec.feet. } \\
174\end{array}$ & $\begin{array}{l}\text { F'eet. } \\
\quad 2.22\end{array}$ & $\begin{array}{r}\text { Sec.-feet. } \\
146\end{array}$ \\
\hline June 2 . & 3.08 & 505 & 3.15 & 232 & 2.30 & 164 \\
\hline June 3 & 5.18 & 1,951 & 3.50 & 349 & 2.50 & 220 \\
\hline June $4 \ldots$ & 6.98 & 3,211 & 3.50 & 349 & 2.82 & 324 \\
\hline June $5 \ldots$ & 10.20 & 5,465 & a 10.20 & $a 8,050$ & 3.45 & 526 \\
\hline June $6 \ldots$ & ${ }^{b} 10.88$ & $b 5,941$ & 7.40 & 3,918 & c 4.30 & $d 876$ \\
\hline June 7 & 10.10 & 5,395 & 5.70 & 2,184 & 3.70 & 684 \\
\hline June 8 & 7.62 & 3,659 & 5.42 & 1,898 & 3.55 & 632 \\
\hline June 9 ... & 6. 30 & 2,735 & 5.42 & 1,898 & 3.50 & 620 \\
\hline June $10 \ldots$ & 5.10 & 1,895 & 5.00 & 1,470 & 3.40 & 588 \\
\hline June 11 & 4.88 & $1,7+1$ & 4.58 & 2,062 & 3.45 & 604 \\
\hline June 12 & 4.58 & 1,531 & 4.42 & 915 & 3.40 & 588 \\
\hline June 13 & 3.90 & 1,055 & 4.25 & 779 & 3.35 & 572 \\
\hline June 14 & 3.78 & 971 & 4.10 & 670 & 3.20 & 524 \\
\hline June 15 & 3.50 & 775 & 4.02 & 617 & 3.12 & 498 \\
\hline
\end{tabular}

a Maximum gage height, 10.20 feet ; maximum discharge, 8,050 second-feet.

${ }^{b}$ Maximum gage height, 11.25 feet; maximum discharge, 6,270 second-feet.

c Maximum gage height, 4.40 feet ; maximum discharge. 908 second-feet.

a Channel changed by flood.

It is seen that the maximum daily stage of Belle Fourche River was attained on June 6 for a gage height of about 10.9 feet and a corresponding discharge of $\mathbf{5 , 9 4 1}$ second-feet. The absolute maximum gage height during. this flood was 11.25 feet and the corresponding discharge was 6,270 second-feet.

Redwater River reached its maximum stage on June 5 for a maximum gage height of 10.2 feet and a corresponding discharge of 8,050 second-feet. The flow of Rapid Creek reached a maximum on June 6 for a maximum gage height of 4.4 feet and a corresponding discharge of 908 second-feet. The flow of this creek during this flood was not as large, compared with its ordinary flow, as that of Belle Fourche and Redwater rivers.

The table following gives additional data on the flow of these streams during this flood. 
Flood duta of the Belle Fourche and tributaries, June, 1904.

\begin{tabular}{|c|c|c|c|c|c|}
\hline \multirow{2}{*}{ Stream and place. } & \multirow{2}{*}{$\begin{array}{c}\text { Drainage } \\
\text { area. }\end{array}$} & \multicolumn{2}{|c|}{ Maximum discharge. } & \multirow{2}{*}{$\begin{array}{c}\text { Total } \\
\text { dis- } \\
\text { charge. }\end{array}$} & \multirow{2}{*}{$\begin{array}{c}\text { Cross sec } \\
\text { tion. }\end{array}$} \\
\hline & & Total. & $\begin{array}{l}\text { Per square } \\
\text { mile. }\end{array}$ & & \\
\hline $\begin{array}{l}\text { Belle Fourche River at Belle } \\
\text { Fourche,S. Dak }\end{array}$ & $\begin{array}{c}\text { Sq. miles. } \\
3,250\end{array}$ & $\begin{array}{l}\text { Sec.-ft. } \\
6,270\end{array}$ & $\begin{array}{l}\text { sec.-ft. } \\
1.81\end{array}$ & $\begin{array}{l}\text { Acre-feet. } \\
45,000\end{array}$ & $\begin{array}{l}\text { Sq.-feet. } \\
1,742\end{array}$ \\
\hline $\begin{array}{l}\text { Redwater River at Belle Fourche, } \\
\text { S. Dak }\end{array}$ & 1,015 & 8,110 & 8.00 & 34,000 & 1,454 \\
\hline Rapid Creek at Rapid $\ldots \ldots$ & 410 & 1,170 & 2.85 & 7,400 & 230 \\
\hline $\begin{array}{l}\text { Belle Fourclie River below mouth } \\
\text { of Wlitewood Creek }\end{array}$ & & 20,000 & & & \\
\hline
\end{tabular}

At no time was there a violent downpour, but all water courses and dry runs gradually became torrents, carrying before them large logs, trees, and débris, damming the channels. In many of the creeks bowlders weighing a ton or more were rolled along by the waters.

DAMAGE DONE BY FLOOD.

The rainfall over the "hills" was much heavier than on the plains, and as the waterways in the former were much smaller than in the latter the upper parts of the streams became raging torrents. Besides the main channels the smaller creeks and dry runs became torrents and discharged large volumes of water. Four lives were lost. The greatest damage was done along Spearfish and Whitewood creeks, where the channels were contracted in many places by railroad and other improvements, and parts of the towns of Deadwood, Central City, and Spearfish were under water.

At Deadwood the water of Whitewood Creek reached a height of 8 feet above normal and 2 feet above danger line, flooding the lower part of the town, undermining many buildings, washing out miles of the railroad track of the Chicago and Northwestern and Burlington and Missouri River railroads, completely destroying the steel bridges in Deadwood, and doing other damage all along its course.

Along Whitewood Creek the list of damages is given as follows.

Damages from Belle Fourche flood.

City of Deadwood, bulkheads and bridges washed out and damage to streets $\$ 25,000$

Lawrence County 60,000

Chicago and Northwestern Railroad 30,000

Burlington and Missouri River Railroad 60,000

Private damage 25,000 
Along Spearfish Creek the Burlington and Missouri River Railroad in the canyon was almost completely washed out and the Government fish hatchery demolished: also consịderable damage to streets and bridges in the town of Spearfish, as well as many private residences and orchards. All mill dams and canal heads were more or less damaged. The damage in Spearfish, outside of the railroad damage, will reach $\$ 20,000$.

All the smelters along Whitewood Creek were forced to close down for some time, and the Homestake mine was shut down for the first time in twenty years on account of inability to secure fuel and the excess of water in the mine. Pl. IV, $B$, illustrates the damage to Chicago and Northwestern Railway along this stream.

Along Belle Fourche River, which receives all the water from the northern hills, no damage was done.

Redwater River, the main branch of the Belle Fourche, was from one-fourth to one-half mile wide and considerable damage was done to meadows along its course.

\section{KANSAS FLOODS.}

By E. C. Murphy.

The floods on Neosho, Verdigris, and Osage rivers in eastern Kansas in July, 1904, were larger and more destructive than any other recorded floods on these streams. The flood on Arkansas River in southern Kansas only lacked 0.8 foot of being as high as during the great flood of 187\%. The flood on Kansas River, while of a stage several feet less than that of the May flood of 1903, was, nevertheless, greater than any recorded prior to that one.

\section{PRECIPITATION.}

The rainfall in eastern Kansas prior to this flood is thus described by Mr. P. Connor in the Monthly Weather Review for July, 1904:

The spring and early summer months, like those of 1903, in Kansas and western Missouri were abnormally wet. At Kansas City there was an excess of nearly 17 inches of precipitation from March 1 to July 8, the date of the highest water. Fortunately for this community and interests below Kansas City, the most violent storm occurred outside the Kansas-commonly known as the Kaw-watershed. The rainfall in Kaw Valley, while far too heavy and frequent for good farm work, was so distributed that the streams could carry it off without overflowing their banks until July 6 , although twice in June rather heavy rains on consecutive days caused a good many of them to become almost bank full in some places. On the morning of July 4 rather heavy rains were reported in Kaw Valley and northwestern Missouri, with the larger streams of Kaw Valley at ordinary stages. On the morning of July 5 only ordinary rains were reported over the same territory. There was, as yet, no cause for serious 
apprehension, but on the afternoon and the night of July 5 uniformly heavy rains fell over the greater portion of Kaw Valley and northwestern Missouri. At Kansas City the fall was 2.31 inches in eighteen hours, and it was equally heavy along Kaw River to Topeka and along the Missouri to some distance helow St. Joseph. The great quantity of rain that fell in the basin at the junction of Missouri and Kaw rivers had immediate effect in raising the rirers at Kansas City, and, in consequence, the Missouri had risen 2.7 feet by the morning of July 6, placing it 1.1 feet above the danger line. Kaw River rose 4 to 5 feet.

The monthly precipitation at several places in southeastern Kansas and adjacent States is given in the following table:

Momthly precipitation and variation from normal in southeastern Kansas and adjacent states, January to July, 1904.

\begin{tabular}{|c|c|c|c|c|c|c|c|c|c|}
\hline Place. & & Jan. & Feb. & Mar. & Apr. & May. & June. & July. & Total. \\
\hline \multirow{2}{*}{ North Platte, Nebr . } & Variation & -0.2 & -0.4 & -0.2 & -0.6 & +0.9 & +1.10 & +2.2 & +2.8 \\
\hline & $\{$ Precipitation & .32 & .06 & $.5 \%$ & 1.58 & 3. 63 & 4.43 & 4.90 & 15.38 \\
\hline \multirow{2}{*}{ Kansas City, Kans } & Variation. & -.4 & -1.2 & +3.3 & +3.8 & +6.1 & -.4 & +2.0 & +13.2 \\
\hline & $\{$ Precipitation. & $.7 \%$ & .69 & 5.51 & 6. 69 & 10.70 & 4.56 & 6.25 & 35.17 \\
\hline \multirow{2}{*}{ Topeka, Kans. } & Variation. & -.1 & -1.6 & +.5 & +2.0 & +2.0 & -.9 & +1.4 & +3.3 \\
\hline & Precipitation. & .92 & .16 & 2.68 & 4. 70 & 6.96 & 3.88 & 6.37 & 25.61 \\
\hline \multirow{2}{*}{ Dodge City, Kans _ } & jVariation. & -.4 & -.6 & -.9 & .0 & +1.2 & -1.3 & -1.4 & -3.4 \\
\hline & Precipitation. & .03 & .02 & .01 & 1.54 & 4.42 & 2.02 & 1.71 & 9.78 \\
\hline \multirow{2}{*}{ Wichita, Kans_ } & $\int$ Variation. & -.8 & -1.2 & +2.4 & -.3 & +1.5 & +.7 & +4.2 & +7.5 \\
\hline & Precipitation & .12 & .04 & 4.23 & 2.65 & 5.74 & 5.69 & 7.46 & 25.98 \\
\hline \multirow{2}{*}{ St. Louis, Mo - } & SVariation & +1.0 & -2.0 & +4.4 & -0.5 & -1.7 & -.4 & -.7 & +.1 \\
\hline & tion. & 3.15 & .84 & 7.87 & 3. 25 & 2. 88 & 4.64 & 3.09 & 25.82 \\
\hline \multirow{2}{*}{ Oklahoma, Okla } & fVariation ..... & +.8 & -.9 & -1.8 & -1.2 & -1.2 & +9.6 & -2.6 & +2.7 \\
\hline & $\{$ Precipitation. & 2.18 & .04 & .26 & 1.51 & 4.31 & 12.33 & 1.07 & 21. 70 \\
\hline \multirow{2}{*}{ Fort Smith, Ark } & fVariation...... & +1.1 & -2.9 & -.5 & -2.7 & -.4 & -1.8 & -1.4 & -3.0 \\
\hline & Precipitation. & 3.48 & .85 & 3.75 & 2.39 & 4.38 & 6.12 & 3.09 & 24.06 \\
\hline Emporia, Kans . & Precipitation & .42 & .09 & 4.01 & 3.15 & 8. 32 & 9.51 & 8.90 & 34.40 \\
\hline Fort Scott, Kans & . . do... & 1.58 & .57 & 1.69 & 10.34 & 6.23 & 12.88 & 8.12 & 41.41 \\
\hline Independence, Kans. & . . . do........ & 1.44 & .16 & 1.58 & 3. 44 & 4.26 & 11. 78 & 9.12 & 31.78 \\
\hline Winfield, Kans . & ....do.... & 1.13 & $\mathbf{T}$. & 1.48 & 2.01 & 6. 47 & 13.22 & 8.96 & 33.97 \\
\hline Hartshorn, Ind. T... & . . . do... & 2.35 & .48 & 4.37 & 3. 68 & 4.83 & 15.00 & & $\ldots$. \\
\hline Okmulgee, Ind. T . & ....do_... & 3.37 & .08 & 1.94 & 1.27 & 10.66 & 13.94 & & - \\
\hline Bonham, Tex ..... & .....do... & 2.26 & 1.72 & .22 & 3.78 & 5.93 & 11.49 & 2.11 & 27.51 \\
\hline
\end{tabular}

The monthly and the accumulated excess or deficiency for the seven months January to July are also given for several of these places. These figures verify Mr. Connor's statement in regard to the precipitation in eastern Kansas, and in a measure define the extent and magnitude of the precipitation prior to this flood:

This excessive precipitation caused floods on Osage, Neosho, and Verdigris rivers larger than ever known before. Compared with the storm that preceded the great flood on Kansas River in 1903, it may be said that that of 1904 did not cover as large an area, was not as intense, occurred about one month later in the season, and was central over an area from 200 to 300 miles farther south. 


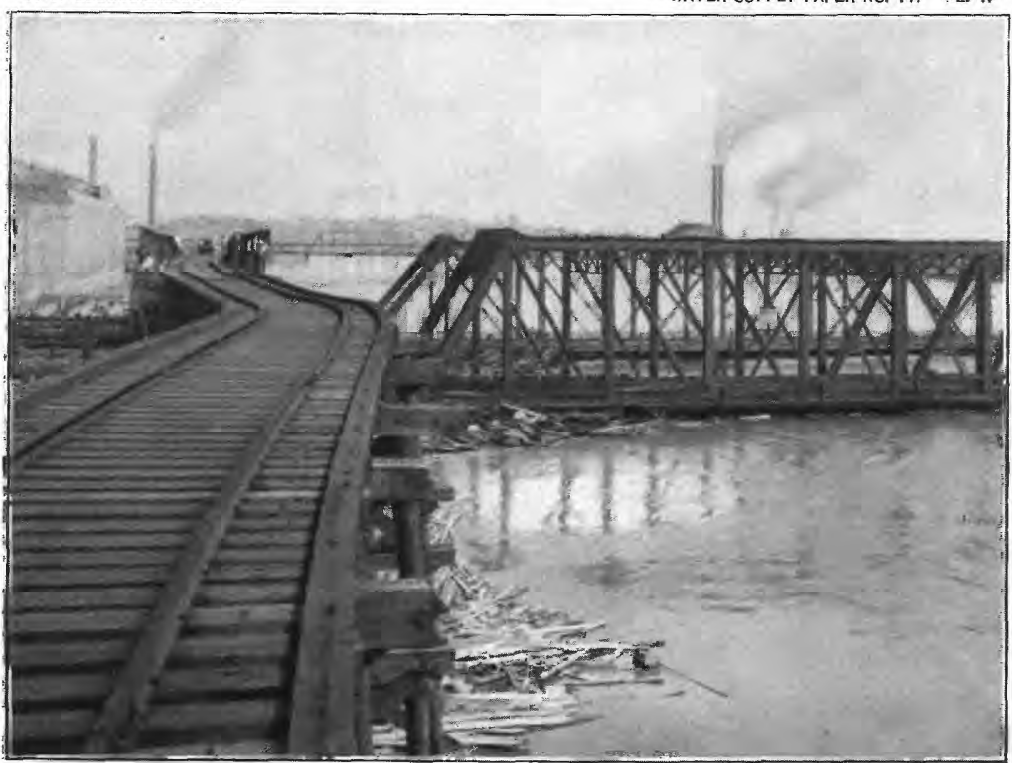

A. MISSOURI PACIFIC AND UNION PACIFIC RAILWAY BRIDGES OVER KANSAS RIVER AT KANSAS CITY DURING FLOOD OF 1904

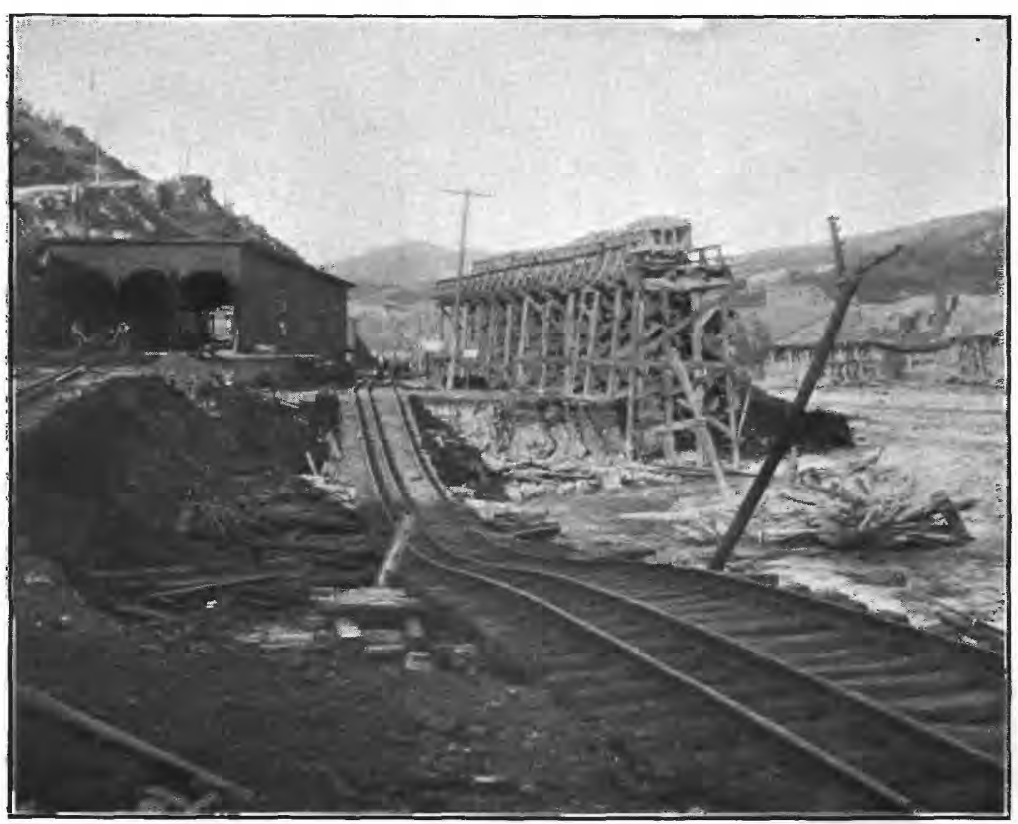

B. DAMAGE TO CHICAGO AND NORTHWESTERN RAILWAY ALONG WHITEWOOD CREEK, SOUTH DAKOTA. 
KANSAS RIVER FLOOD.

GENERAL STATEMENT.

The greatest flood of Kansas River on record or in the memory of the oldest inhabitants living along the stream occurred May 23 to June 13, 1903. ${ }^{a}$

The flood of July, 1904, although it did not reach to within about $8 \frac{1}{2}$ feet of the height attained by that of 1903 at the United States gaging station at Lecompton, was, however, second to it in recorded height. Its estimated discharge was about 60 per cent of that of the flood of 1903 and about double that of the flood of April 26, 1897, which was the greatest in twenty-one years prior to 1903 . The area flooded in 1904, while much less than that flooded in 1903, was nevertheless large, and, as the flood occurred about a month later than in 1903 , it prevented the maturing of ordinary crops on the flooded area.

The effect of the 1903 flood on Kansas River was to deepen and widen the channel and in some places, notably near Manhattan and St. Marys, to straighten it by cutting off bends in the stream. A short distance south of the latter place a new channel about 4 miles long was formed and a few miles farther downstream another, onehalf mile long, was cut across an oxbow bend. At many places along the concave bank washing took place, and where the banks were not protected erosion occurred, resulting in some places in the destruction of several acres of land. This erosion of bed and banks supplied a vast amount of material that was deposited on the flooded area. In places this deposit consists of from 2 to 6 inches of silt that enriches the land and in other places of from 2 to 6 feet of sand that completely ruins it. It is estimated that 10,000 acres of fine farming land along the river, valued at $\$ 200$ per acre, were thus practically destroyed.

\section{FLOOD NEAR KANSAS CITY.}

The flood of 1903 destroyed 16 bridges in the vicinity of Kansas City, only one of which had been removed from the stream bed prior to the flood of 1904 . Several temporary pile bridges had been constructed across the river between the dates of the two floods. These and other obstructions collected drift, retarded the flow, and increased the area of overflow. One of these pile bridges, the Rock Island Railway bridge, was destroyed by this flood, and other bridges were damaged to some extent.

\footnotetext{
a For a description of the Kansas River basin and of the flood of 1903 and the destruction wrought by it, see Destructive floods in the United States in 1903: WaterSup. and Irr. Paper No. 96, U. S. Geol. Survey, 1904.
} 
Gage height and discharge.-The following table ${ }^{a}$ gives the fluctuations of Missouri River at the Hannibal Bridge at Kansas City, and of Kansas River at the Stock Yards Bridge (about 3.miles from the Hannibal Bridge), at Topeka, and at Manhattan during the flood:

Fluctuations of Kansas and Missouri rivers, July 1 to 13, 190\%.

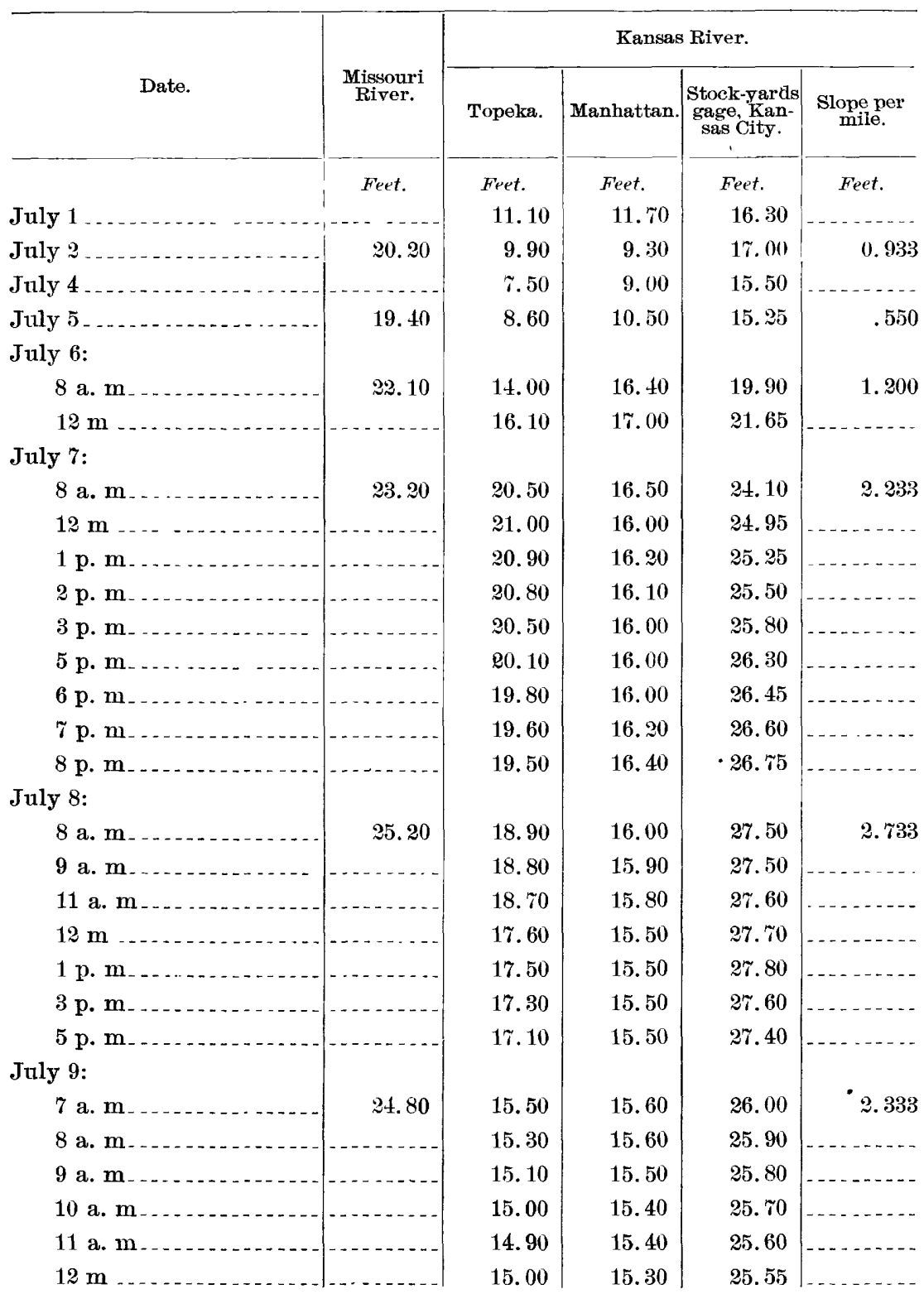

a Data furnished by Mr. H. A. Wise, engineer Kansas City Stock Yards Company. 
Fluctuations of Kansas and Missouri rivers, July 1 to 13, 1904-Continued.

\begin{tabular}{|c|c|c|c|c|c|}
\hline \multirow[b]{2}{*}{ Date. } & \multirow[b]{2}{*}{$\begin{array}{l}\text { Missouri } \\
\text { River. }\end{array}$} & \multicolumn{4}{|c|}{ Kansas River. } \\
\hline & & Topeka. & Manhattan. & $\begin{array}{c}\text { Stock-yards } \\
\text { gage, Kan- } \\
\text { sas City. }\end{array}$ & $\begin{array}{l}\text { Slope per } \\
\text { mile. }\end{array}$ \\
\hline July 9: & Feet. & Feet. & Feet. & Feet. & Feet. \\
\hline 2 p. m. & $\ldots$ & 14.90 & 15.20 & 25.40 & $\ldots$ \\
\hline 4 p. m & . & 14.80 & 15.00 & 25.00 & \\
\hline July 10: & & & & & \\
\hline \% a. m. & . & 14.00 & 14.00 & 22.85 & $-\ldots$. \\
\hline $12 \mathrm{~m} \ldots$ & $\ldots$ & 13.40 & 13.90 & 22.25 & $\ldots \ldots$ \\
\hline July 11,8 a. $\mathrm{m}_{\ldots}$ & 21.90 & 12.70 & 13.70 & 20.00 & 1.300 \\
\hline July 12,8 a. m - & 20.30 & 12.00 & 13.30 & 17.80 & 1.100 \\
\hline July 13,8 a. m. & 19.10 & 11.80 & 13.60 & 16.20 & .967 \\
\hline
\end{tabular}

The gage on the Hannibal Bridge is the property of the United States Weather Bureau, and the readings of it were furnished by Mr. P. Connor. The datum of this gage is 5.8 feet lower than that of the stock-yards gage. It is seen that this flood reached its maximum height at 1 p. m. on July 8 at a gage reading of 27.8 feet, or a height of 28 feet above low water. The maximum height was reached at Topeka at noon July $\tau$ and at Manhattan at noon July 6 . The crest of the 1903 flood reached an elevation at the Hannibal Bridge about 10 feet greater than that of 1904 . The difference in elevation of the crest of these floods at the stock yards must have been several feet greater than this on account of the much greater choking effect due to the collection of drift at the Union Pacific Railway bridge.

Column 6 gives the slope of the surface in feet per mile from the Stock Yards Bridge to the Hannibal Bridge during this flood. The slope is not constant, but varies directly with the stage. The greatest slope was about 2.73 feet per mile. During the 1903 flood the slope of the surface from the Union Pacific bridge to the mouth of the Kansas was about 4.34 feet per mile. For a distance of about T.000 feet upstream from the Union Pacific bridge the slope was about 1.26 feet per mile. Farther up the river the slope was about $1 \frac{1}{2}$ feet per mile. The slope of Kansas River for some miles from its mouth is affected by the stage of the Missouri. It was a very fortunate occurrence that during the floods of both 1903 and 1904 Missouri River was not at its highest stage. If the great floods in this ruver had been coincident, the damage due to overflow in Kansas City would have been even greater than it was.

A flood-discharge measurement of Missouri River was made at 
Hannibal Bridge May 12, 1904, for a mean gage reading of 20.5 feet (about $5 \frac{1}{2}$ feet below the crest of the flood of 1904), and gave an area of 28,036 square feet, with a discharge of 152,300 cubic feet per second. A flood-discharge measurement of Kansas River was made on July 12, 1904, from the elevated-railroad bridge in Kansas City, for a gage height (Hannibal Bridge gage) of about 20 feet, or a surface elevation (stock-yards datum) of 15.8 feet. The width between abutments at this bridge is about 595 feet; the maximum depth, 25.9 feet; area, 10,125 square feet; discharge, 58,900 cubic feet per second; the total waterway under the bridge is 21,320 square feet. Both banks of the river at this point are several feet lower than the surface of this bridge, as the new bridge is about 6 feet higher than the old one, which was destroyed in 1903.

Necessary waterway.-With the aid of Kutter's mean-velocity formula we may compute the necessary width of a trapezoidal waterway, with side slopes 1 to 1 , to carry the flood of 1903 with a maximum depth of 30 feet. The estimated maximum discharge at the United States gaging station at Lecompton was 233,000 cubic feet per second. Adding 8 per cent of this volume for the volume received between Lecompton and Kansas City we have 251,715 cubic feet, or in round numbers 252,000 cubic feet per second as the discharge of Kansas River at Kansas City. The slope from the table above is about 2.75 feet per mile. The coefficient of roughness $n$ is about 0.030 . From these data we find that the mean velocity will be about 10 feet per second, and that the bottom width of the trapezoidal area necessary would be 710 feet, and the top width 770 feet. This waterway would have permitted the flood of 1903 to pass Kansas City with a surface height not greater than that during the flood of 1901 that is, a surface elevation at the elevated-railroad bridge of 20 feet (stock-yards datum). Some of the bottom lands would have been flooded under those conditions unless low levees had been constructed on each side of the river. If the channel width is restricted to 580 feet with vertical sides, surface slope of 2.75 feet per mile, then the depth must be about 39 feet. In these computations no allowance is made for reduction of waterway due to collection of drift in front of piers or to the piers themselves.

Pl. IV, A, shows the Missouri Pacific and Union Pacific railway bridges across Kansas River in Kansas City when the flood of July 7, 1904, had begun to recede. The Missouri Pacific bridge shown was the only one across the Kansas River at Kansas City that escaped destruction in 1903. The new Union Pacific bridge is at the same elevation above low water as the old one, and the channel under it has not been widened; in fact, the only effort made in Kansas City to prevent loss due to floods between the dates of these floods was the construction of a few of the new bridges at a few feet greater elevation 


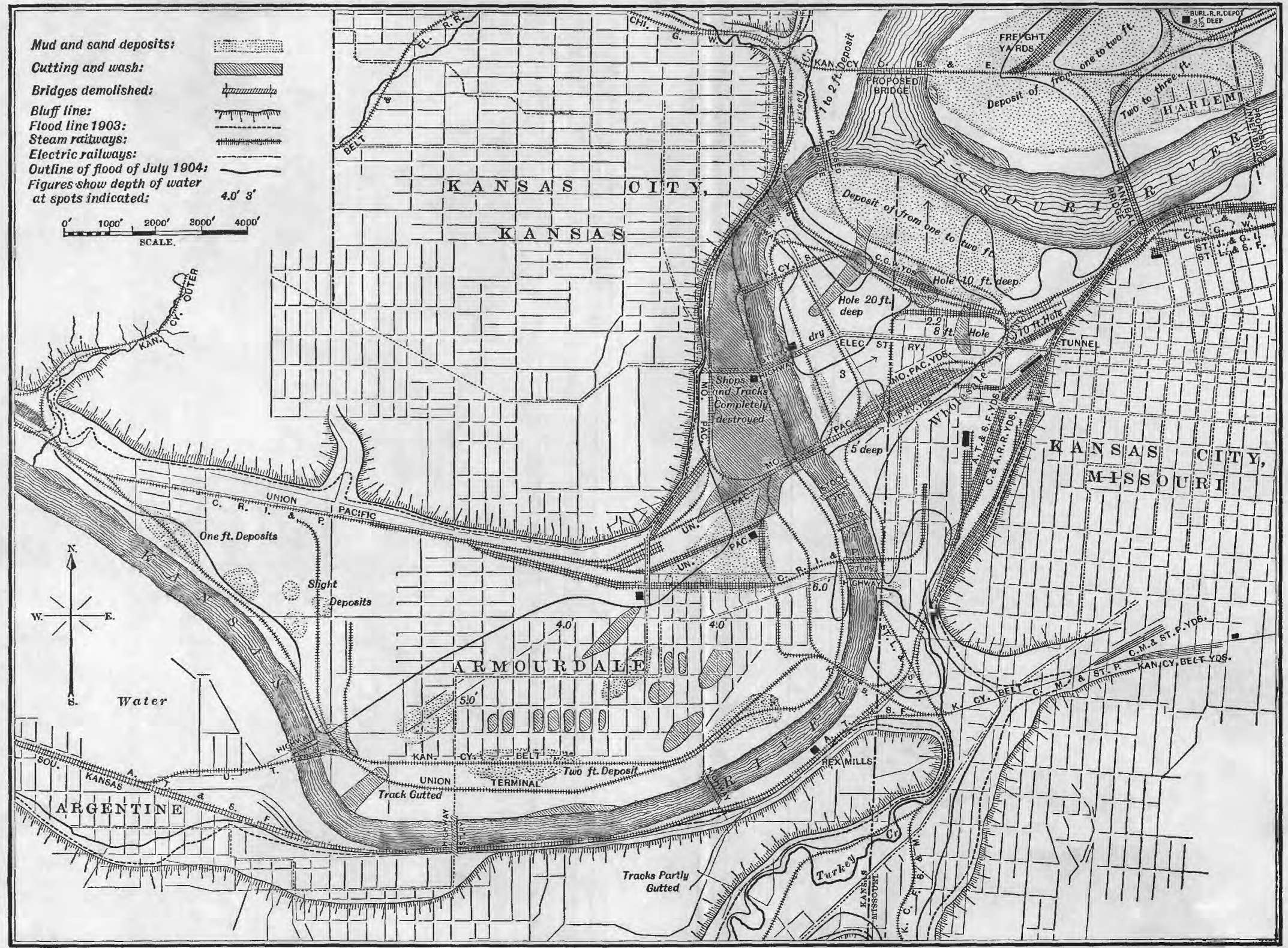

KANSAS CITY, SHOWING AREA FLOODED IN 1903 AND 1904. 
than the old ones which were destroyed. The channel has not been widened, although at one place it is less than 450 feet in width. The spans of the bridges have not been lengthened, the channel has not been cleared of wreckage nor deepened, nor have levees been constructed to prevent overflow. The 1904 sflood, although it did not reach within several feet of the height of the 1903 flood, nevertheless overflowed many acres of bottom land, drove a large number of people from their homes, and destroyed many thousand dollars' worth of property. Pl. V shows the areas submerged during the flood of 1903 and during that of 1904 .

Recommendations of army engineers. - A board of army engineers, consisting of Col. Amos Stickney, Maj. J. G. Warren, and Capt. H. H. Chittenden, Corps of Engineers, reported January 23, 1904, on the flood conditions of Kansas River in Kansas City. This report states that the normal average width of Kansas River through Kansas City, which was 850 feet, the minimum width having been 540 feet, has been reduced to an average width of 590 feet, the minimum width being 420 feet. The bridges have more piers than is necessary and are founded on piles. Between and around the piers are piles and loose rock that prevent the natural scour of the bed in time of flood. As a result of these encroachments on the river the natural channel capacity for carrying off floods has been reduced to about one-half.

The measures declared necessary to avert another disaster like that caused by the 1903 flood are to restore to the river in Kansas City a width of at least 734 feet; to construct masonry walls on each side reaching to an approximate height of 30 feet above low water for a distance of 17,000 feet above the mouth; to dredge the river bed of all solid obstructions to a depth of 15 feet below low water; to limit the number of piers to two, 300 feet apart, carried down to rock, and having the lowest part of the structure on them above the flood line of 1903, and to construct earth levees with paved slopes above the point where masonry walls are necessary, and carry these to the bluffs above Argentine and Armourdale.

Inasmuch as this improvement would be very expensive and require a long time to carry out, the board recommended the following measures as a minimum requirement under existing conditions:

(1) That further encroachments on the banks be stopped and existing encroachments be removed, so as to give the channel an average width of at least 600 feet for a distance of 17,000 feet above the mouth.

(2) That the channel be cleared of all obstructions to a depth of at least $\mathbf{1 5}$ feet below standard low water.

(3) That all bridge owners be required to remove obstructions around or hetween existing piers and to construct their bridges with only two piers, to be

IRR $147-05 \mathrm{M}-\mathrm{5}$ 
carried down to rock and to be 300 feet apart, measured on a line perpendicular to the center line of the channel, the lowest point of the structure to be above the flood line of the ultimate channel.

Since the above was written the Kansas legislature has authorized the formation of drainage districts in Kansas. The directors of each district have control of all the streams in the district and provide for widening, deepening, and straightening the channel and the construction and maintenance of levees to prevent overflow. A district extending from above Argentine to the mouth of Kansas River has been organized, surveys are being made, plans and estimates prepared tor the passage of a rate of flow of 160,000 second-feet without overflow. The United Zinc and Chemical Company in this district has already constructed a levee to protect its property at a cost of $\$ 15,000$. The Armour Packing Company has also constructed a levee to protect its property.

\section{FLOOD NEAR LAWRENCE, KANS.}

From high-water marks above the dam at Lawrence it was found that the depth of water on the crest of the dam, measured at a point sufficiently far upstream to be out of the influence of the curvature of the surface near the crest, was 19.7 feet in the 1903 flood and 13.5 feet in that of 1904 -that is, the crest of the former flood was about f.2 feet higher than that of the latter. The high-water marks on the south side are about 9 inches higher than those on the north side, this being due to the bend in the stream. The 1903 flood cut a new channel about 400 feet wide and so deep that all the ordinary flow passed through it around the north end of the bridge. This channel was filled with rock in October, 1903, reducing the waterway to its former dimensions. The 1904 flood passed over the end of this fill and was prevented from cutting another new channel only by a levee of sand bags. About one-fourth mile farther north the river overflowed the Union Pacific Railway embankment, washed out several hundred feet of track, and submerged several hundred acres of low land in the vicinity of Lawrence. A part of the apron of the dam was washed out during this flood, and later a part of the dam itself and of the north abutment of the bridge.

Since the above was written the length of the crest of this dam has been increased about 65 feet, thus increasing the width of the channel about 11 per cent. The cost of this work, including a new abutment and truss for the bridge and the filling of the new channel cut by the flood of 1903 , was $\$ 75,000$.

FLOOD NEAR LECOMPTON, KANS.

Gage height and discharge.-The mean daily fluctuations of the surface of Kansas River at this place and the corresponding daily rate 
of discharge during this flood, as shown by the United States Geological Survey gage on the highway bridge, and also the corresponding data for the flood of 1903 are as follows:

Gage height and discharge of Kansas River at Lecompton, Kans., May 2.5 to June 8, 1903, and June 9 \& to July 1\%, 190\%.

\begin{tabular}{|c|c|c|c|c|c|}
\hline Date. & $\begin{array}{c}\text { Gage } \\
\text { height. }\end{array}$ & Discharge. & Date. & $\begin{array}{c}\text { Gage } \\
\text { height. }\end{array}$ & Discharge. \\
\hline 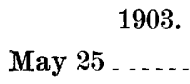 & $\begin{array}{l}\text { Feet. } \\
14.15\end{array}$ & $\begin{array}{l}\text { Sec.-feet. } \\
80,075\end{array}$ & $\begin{array}{r}1904 . \\
\text { June } 28 .\end{array}$ & $\begin{array}{l}\text { Feet. } \\
12.00\end{array}$ & $\begin{array}{l}\text { Sec.-feet. } \\
\quad 41,040\end{array}$ \\
\hline May 26 & 12.15 & 55,500 & June 29 & 10.70 & 32,670 \\
\hline May 27 & 16.60 & 99,500 & June 30 & 10.05 & 28,600 \\
\hline May 28 & 18.00 & 113,500 & July 1 . & 11.10 & 35,150 \\
\hline May 29 & 21.10 & 144.500 & July 2 & 9.60 & 26,450 \\
\hline May $30 \ldots$ & 24.00 & 173,500 & July $3 \ldots$ & 8.70 & 21,920 \\
\hline May 31 & a28.75 & 221,000 & July 4 & 8.45 & 20,500 \\
\hline June 1 & 27.20 & 205,500 & July 5 & 10.10 & 29,160 \\
\hline June 2 & 26.25 & 196,500 & July 6 & 16.75 & 91,040 \\
\hline June 3 & 26.35 & 197,500 & July $\tau_{\ldots} \ldots$ & $20 . \dot{75}$ & 130,000 \\
\hline June 4. & 24.35 & $17 \%, 500$ & July 8 & 18.75 & 110,000 \\
\hline June 5 & 23.05 & 164,500 & Jaly $9 \ldots$ & 16.45 & $8 \%, 120$ \\
\hline June 6 & 20.50 & 138,500 & July $10 \ldots$ & 14.55 & 70,060 \\
\hline June $\tau_{\ldots} \ldots$ & 18.20 & 115,500 & July 11 & 13.15 & 57,720 \\
\hline June 8 & 16.50 & 98,500 & July 12 & 12.10 & 48,760 \\
\hline 1904. & & & July 13 & 11.40 & 43,560 \\
\hline June 24. & 6.15 & 11,530 & July $14 \ldots$ & 11.00 & 40,700 \\
\hline June 25. & 10.50 & 31,460 & July 15 & 10.50 & 37,230 \\
\hline June $2 \mathbf{6}_{-}$ & 14.70 & 59,800 & July 16 & 9.55 & 31,390 \\
\hline June 27. & 13. 70 & 52,800 & July 17 & 8.95 & 27,800 \\
\hline
\end{tabular}

a Maximum gage height, 29.50 feet.

It is seen that this flood lasted from July 5 to 15 , reaching a maximum at about noon on July $\bar{\gamma}$, with a gage reading of about 21 feet and an estimated discharge of about 130,000 cubic feet per second. The highest reading of this gage in 1903 was 29.5 feet, so that the crest of the 1903 flood was 8.5 feet higher than the crest of the 1904 flood at this place. The left bank was overflowed for a distance of about 300 feet in the 1904 flood, and a distance of at least one-half mile during the 1903 flood.

Fig. 6 shows graphically the change in volume with the time from the beginning of each of these floods, also the change in the volume for the flood of 1902. Each ordinate of this diagram represents volume of flow per second in thousand second-feet; each abscissa represents days from the beginning of the flood. The magnitude of 
the 1903 flood, as compared with that of 1904 and 1902 , is clearly seen.

The tables on pages 75 and 76 give the mean daily gage height and corresponding discharge of Blue River near Manhattan, and of Smoky Hij] River at Ellsworth, during the flood of 1903, for comparison with the floods at those places in 1904 .

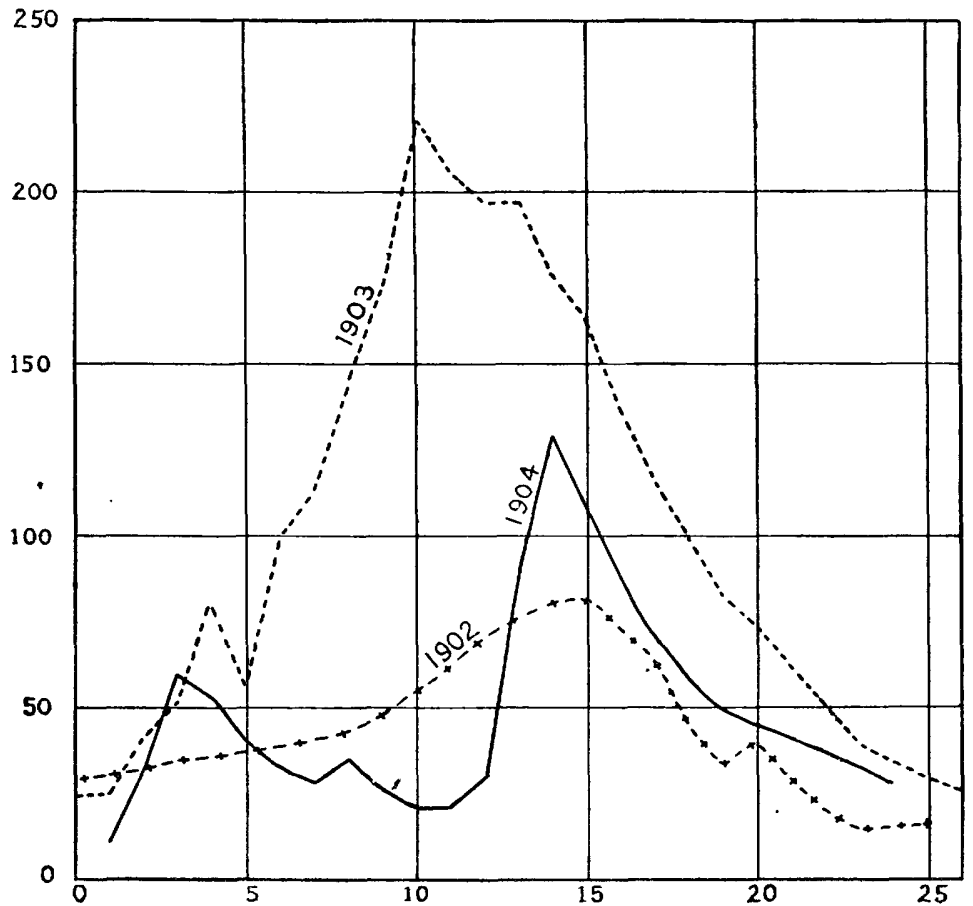

Fig. 6.-Flood discharge of Kansas River at Lecompton. Kans., in 1902, 1903, and 1904.

Necessary waterway.-The width of the channel between the abutments of the. bridge at Lecompton is 800 feet. When the flood of June, 1903, was at its maximum stage the left bank was overflowed for a distance of at least one-half mile, but most of this overflow had very little velocity, and the discharge through the overflow part of the cross section was not more than 5 per cent of the total discharge. The right bank, along which are the Santa Fe Railway tracks, was submerged for a distance of about 110 feet.

The area of the water cross section at this station when the 1904 flood was at its highest stage was 17,S30 square feet; the measured mean velocity was about 7.3 feet per second, and the mean depth was about 22 feet. By Krutter's formula it is possible to compute the mean velocity in a trapezoidal cross section, and thus by trial to determine the proper size of section to carry the flood of 1903 without too great surface elevation. In such a section of bottom width 750 
feet, side slopes $1 \frac{1}{2}$ to 1 , and depth of 22 feet, passing the 1904 flood with a surface slope of $1 \frac{1}{2}$ feet per mile and a coefficient of roughness $n$ equaling 0.030 , the mean velocity is found to be about 6.6 feet per second, 0.7 foot per second less than the mean measured velocity, indicating either a greater surface slope than $1 \frac{1}{2}$ feet per mile or a smaller value of $n$ than 0.030 , or both. If the slope is 2 feet per mile and the other data remain the same as before, the velocity becomes 7.4 feet per second, 0.1 second-foot greater than the observed velocity. It is not likely that the slope was greater than 2 feet per mile, hence the value of $n$ was less than 0.030 .

The next question is to determine what would have been the mean velocity in this assumed trapezoidal channel if all the water of the 1903 flood had flowed in it (without scour and without increase in surface elevation of the flood crest) with a mean depth of 30.8 feet, a surface slope of 2 feet per mile, and $n=0.025$. The total estimated discharge is 233,000 second-feet; area, 24,270 square feet; observed velocity, 9.6 feet per second. By the use of Kutter's formula the mean velocity of the water in the assumed trapezoidal section is found to be 10.2 feet per second. Hence this trapezoidal waterway with bottom width of 750 feet and top width of 842 feet would luave carried the 1903 flood past this station if levees were built to prevent overflow, without any increase in elevation of the crest of the flood.

The following table gives the maximum and minimum discharge of the Kansas at Lawrence and Lecompton each year since 1891:

Marimum and minimum daily discharge of Kansas River at Lanrence, ${ }^{a}$ Kans., 1891 to 1898, and at Lecompton, b Kans., 1899 to 1904.

\begin{tabular}{|c|c|c|c|c|c|c|c|c|}
\hline \multirow[b]{2}{*}{ Year. } & \multicolumn{4}{|c|}{ Maximum discharge in second-feet. } & \multicolumn{4}{|c|}{ Minimum discharge in second-feet. } \\
\hline & Date. & $\begin{array}{l}\text { Gage } \\
\text { height. }\end{array}$ & $\begin{array}{l}\text { From to- } \\
\text { taldrain- } \\
\text { age area. }\end{array}$ & $\begin{array}{l}\text { Per } \\
\text { square } \\
\text { mile. }\end{array}$ & Date. & $\begin{array}{l}\text { Gage } \\
\text { height. }\end{array}$ & $\begin{array}{l}\text { From to- } \\
\text { tal drain- } \\
\text { age area. }\end{array}$ & $\begin{array}{c}\text { Per } \\
\text { square } \\
\text { mile. }\end{array}$ \\
\hline 1891 & June & 6. 40 & 35,750 & 0.597 & January - & 0.20 & 967 & 0.016 \\
\hline 1892 & May ... & 9.20 & & $\ldots$. & $\begin{array}{l}\text { September, Oc- } \\
\text { tober, and De- } \\
\text { cember. }\end{array}$ & .00 & 787 & .013 \\
\hline 1893 & $\begin{array}{l}\text { June and } \\
\text { July. }\end{array}$ & 4.60 & 21,440 & .358 & $\begin{array}{l}\text { September and } \\
\text { December. }\end{array}$ & .00 & 787 & .013 \\
\hline 1894 & June ........ & 5.60 & 28,990 & .484 & & & & \\
\hline 1895 & Angust & 5. 50 & 28,190 & $.4 i 1$ & -... & - . & - & $\ldots$ \\
\hline 1896 & July ... & 7.70 & 53,308 & .891 & January & -.75 & 698 & .012 \\
\hline 1897 & April . & 8.80 & 58,000 & .969 & December & -1.70 & 562 & .0094 \\
\hline 1898 & June & 5.60 & 28,990 & .484 & - . . do . . . & -2.25 & 507 & .0085 \\
\hline 1899 & July & 11.00 & 30,250 & $.51 \%$ & October & 1.90 & 1,750 & .030 \\
\hline 1900 & March & 10.20 & 24,898 & .425 & February & 2.20 & 2,830 & .048 \\
\hline 1901 & April & 10.00 & 25,000 & .427 & $\begin{array}{l}\text { July, August, } \\
\text { and November. }\end{array}$ & 2.00 & 275 & .0047 \\
\hline 1902 & July & 17.60 & 81,400 & 1.39 & March & 1.80 & 100 & .0017 \\
\hline 1903 & May..... & 98.75 & $\approx 21,000$ & 3. 77 & October.... & 3.00 & 2,375 & .041 \\
\hline 1904 & July & 20.75 & 130,000 & 2.22 & $\ldots$ & - & - & $\ldots$ \\
\hline
\end{tabular}


FLOODS NEAR TOPEKA, KANS.

Gage height.-At the time of the July, 1904, flood there were three river gages at Topeka, two belonging to the United States Geological Survey and one belonging to the Wolff Packing Company. One of the United States gages was on a pier of the Rock Island Railway bridge and the other was on a pier of the Santa Fe Railway bridge. Each consisted of foot and tenth marks painted on the side of a pier. The Wolff Packing Company gage consisted of a vertical timber marked to feet and tenths and fastened to the right bank of the river near their packing house. The location of these gages is shown in fig. 8. The readings of the Wolff gage are given on page 62 . The readings of the United States gage on the Rock Island Railway bridge are given below.

Gage height, in feet, of Kansas River at North Topeka, Kans., May 28 to June 11), and Juthe 2.5 to July :20, 1904 .

\begin{tabular}{|c|c|c|c|c|c|}
\hline Date. & Time. & $\begin{array}{c}\text { Gage } \\
\text { height. }\end{array}$ & Date. & Time. & $\begin{array}{c}\text { Gage } \\
\text { height. }\end{array}$ \\
\hline & & Feet. & & & F'eet. \\
\hline \multirow[t]{2}{*}{ May 28.} & 7.45 a. $\mathrm{m}$ & 6.7 & June 9 & $1.30 \mathrm{p.} \mathrm{m}$ & 9.4 \\
\hline & $1.30 \mathrm{p.m}$ & 6.55 & June 10 & 7.45 a. $\mathrm{m}$ & 9.7 \\
\hline \multirow[t]{2}{*}{ May 29} & 7.30 a. m & 11.2 & & 1.30 p. m & 10.3 \\
\hline & 2 p. $\mathbf{m}_{-}$ & 13.5 & June 25 & 7.45 a. $\mathrm{m}$ & 11.3 \\
\hline \multirow[t]{2}{*}{ May $30 \ldots$} & 5 a. $\mathrm{m}_{\ldots}$ & 18.0 & & $1.30 \mathrm{p.} \mathrm{m}$ & 12.8 \\
\hline & 1.30 p. m & 17.1 & June 26 & 8.15 a. $\mathrm{m}$ & 17.1 \\
\hline \multirow[t]{2}{*}{ May $31 \ldots$} & 7.45 a. $\mathrm{m}$ & 12.8 & & $3 \mathrm{p} . \mathrm{m}$ & 16.6 \\
\hline & $1.30 \mathrm{p.} \mathrm{m}$ & 11.95 & June $2 \%$ & 8.15 a. $\mathrm{m}$ & 15.9 \\
\hline \multirow[t]{2}{*}{ June 1} & 7.45 a. $\mathrm{m}$ & 10.8 & & 2 p. m... & 15.5 \\
\hline & 1.30 p. m & 10.5 & June 28 & 8 a. $\mathrm{m}_{-}$ & 14.1 \\
\hline \multirow[t]{2}{*}{ June 2} & $7.45 \mathrm{a} . \mathrm{m}$ & 11.4 & June 29 & 7.45 a. $\mathrm{m}$ & 12.7 \\
\hline & 1.30 p. m & 11.8 & June 30 & 7.45 a. $\mathrm{m}$ & 11.7 \\
\hline \multirow[t]{2}{*}{ June 3} & 7.45 a. $\mathrm{m}$ & $12: 2$ & July 1 . & 7.45 a. $\mathrm{m}$ & 13.2 \\
\hline & $1 . \approx 0 \mathrm{p} . \mathrm{m}$ & 12.2 & July 2 & 8 a. $\mathbf{m}_{-}$ & 11.7 \\
\hline \multirow[t]{2}{*}{ June 4} & 7.45 a. $\mathrm{m}$ & 12.6 & July 3 & 8 a. m & 10.3 \\
\hline & 1.30 p. $\mathrm{m}$ & 12.1 & July 4 . & 9.45 a. $\mathrm{m}$ & 10.5 \\
\hline \multirow[t]{2}{*}{ June 5} & 8.15 a. $\mathrm{m}$ & 12.7 & July 5 .. & T.45 a. $\mathrm{m}$ & 10.5 \\
\hline & 2.20 p. m & 12.8 & July 6 . & ra. $\mathrm{m}$ & , 16.1 \\
\hline \multirow[t]{2}{*}{ June 6} & 7.45 a. $\mathrm{m}$ & 12.5 & & 1.30 p. m & 18.5 \\
\hline & 1.30 p. m & 12.2 & July $\tau_{-}$ & 6 a. $\mathrm{m}$ & 22.3 \\
\hline \multirow[t]{2}{*}{ June $r$} & 7.45 a. $\mathrm{m}$ & 11.1 & & $\tau$ p. m & 21.8 \\
\hline & 1.30 p. m & 10.1 & July 8 & 7.45 a. $\mathrm{m}$ & 19.8 \\
\hline \multirow[t]{2}{*}{ June 8} & 7.45 a. $\mathrm{m}$ & 10.1 & & $5.30 \mathrm{p} . \mathrm{m}$ & 19.0 \\
\hline & 1.30 p. m & 10.0 & July 9 & 7 a. $\mathrm{m}$ & 18.9 \\
\hline June 9 & 7.45 a. $\mathrm{m}$ & 9.1 & & 5 p. m & 18.3 \\
\hline
\end{tabular}


Gage height, in feet, of Kansas River at North Topeka, Kans., 1904-Continued.

\begin{tabular}{|c|c|c|c|c|c|}
\hline Date. & Time. & $\begin{array}{c}\text { Gage } \\
\text { height. }\end{array}$ & Date. & Time. & $\begin{array}{c}\text { Gage } \\
\text { height. }\end{array}$ \\
\hline & & Feet. & & & Feet. \\
\hline \multirow{2}{*}{ July 10} & \% a. m. & 17.4 & July 15. & $7.45 \mathrm{a} . \mathrm{m}$ & 12.9 \\
\hline & 5 p. m $\ldots$ & $1 \% .0$ & & 2 p. $\mathrm{m}_{\ldots} \ldots$ & 12.7 \\
\hline \multirow[t]{2}{*}{ July 11} & 7.30 a. $\mathrm{m}$ & 16.7 & July 16 . & 7.45 a. $\mathrm{m}$ & 12.2 \\
\hline & 5 p. m... & 16.0 & & $2 \mathrm{p} . \mathrm{m}$. & 12.0 \\
\hline \multirow[t]{2}{*}{ July 12. } & 7 a. m... & 14.0 & Juy $17 \ldots$ & 9 a. $\mathrm{m}_{-}$ & 11.6 \\
\hline & 5 p. m... & 14.0 & & $3 \mathrm{p} . \mathrm{m}_{\ldots}$. & 11.2 \\
\hline \multirow[t]{2}{*}{ July 13} & 7.45 a. $\mathrm{m}$ & 13.7 & July $18 \ldots$ & $7.45 \mathrm{a} . \mathrm{m}$. & 10.9 \\
\hline & 1.30 p. m & 13.8 & & 2 p. m $\ldots$ & 10.5 \\
\hline \multirow[t]{2}{*}{ July 14} & 7.45 a. $\mathrm{m}$ & 13.7 & July $19 \ldots$ & 7.45 a. $\mathrm{m} \ldots$ & 9.7 \\
\hline & 2 p. m.. & 13.7 & July $20 \ldots$ & 7.45 a. $\mathrm{m} \ldots$ & 8.6 \\
\hline
\end{tabular}

The flood reached its height on July 7 , for a reading of about 22.3 feet, ${ }^{a}$ or about 17.8 feet above low water. The elevation of the highwater mark of 1903 on the engine room of the Wolff Packing Company is 902.63 feet and of the 1904 flood 896.44 feet, so that the high water of 1903 was about 6.2 feet higher than the high water of 1904 at this place. The former flood came to the top of the rail of the Santa Fe Railway bridge and was about 43 inches in depth on the rail of the Roek Island Railway bridge. The latter flood reached the under surface of the Rock Island Bridge and took out the false works of one span. There was therefore a difference of only 6.2 feet in the elevation of the crest of these floods at Topeka, whereas there was a difference in elevation of the crest at Lecompton of 8.5 feet.

Obstructions in channel.-During the flood in 1904 two cableways that had been used for lifting sand from the bed of the river were in the river bed with the ends fastened to the trees on shore; these collected drift and retarded the flow. Some distance farther downstream was a Melan arch bridge, with its large piers and small, low arches, in front of which large quantities of drift collected. A few feet above this bridge were the ruins of a pile bridge destroyed by the 1903 flood, and about 50 feet below was a second pile bridge, the bents of which were 30 feet apart. These three bridges so near together and of such small, short spans collected the drift and formed a dam. The Melan bridge (fig. 7 ) has 5 arches, the central one having a span of 124 feet, the two adjacent spans of 110 feet, and the other two spans of 96 feet. The waterway below the spring lines of these arches was about $9,600^{b}$ square feet. This is only about 40 per cent of the

\footnotetext{
a This reading may be in error one or two tenths of a foot on account of its being impossible for the reader to get near the gage, one span of the bridge having washed out.

${ }^{-}$Result based on soundings taken July 19, 1904 .
} 
smallest area found necessary to pass the 1903 flood at Lecompton, and only 56 per cent of the waterway necessary to pass the $190 t$

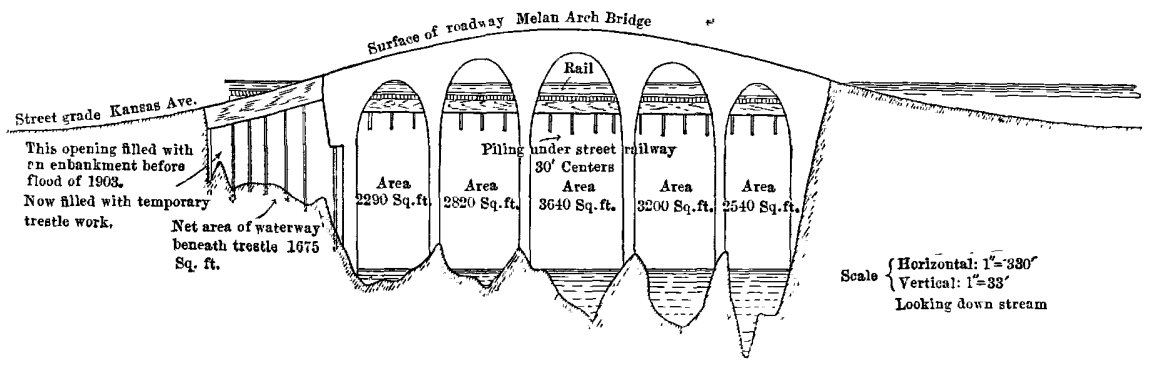

FIG. 7.-Cross section of Kansas River at Melan arch bridge, Topeka, Kans.

flood. It is little wonder that the left abutment of this bridge was washed out in the 1903 flood, as shown in Pl. VI, A, and a

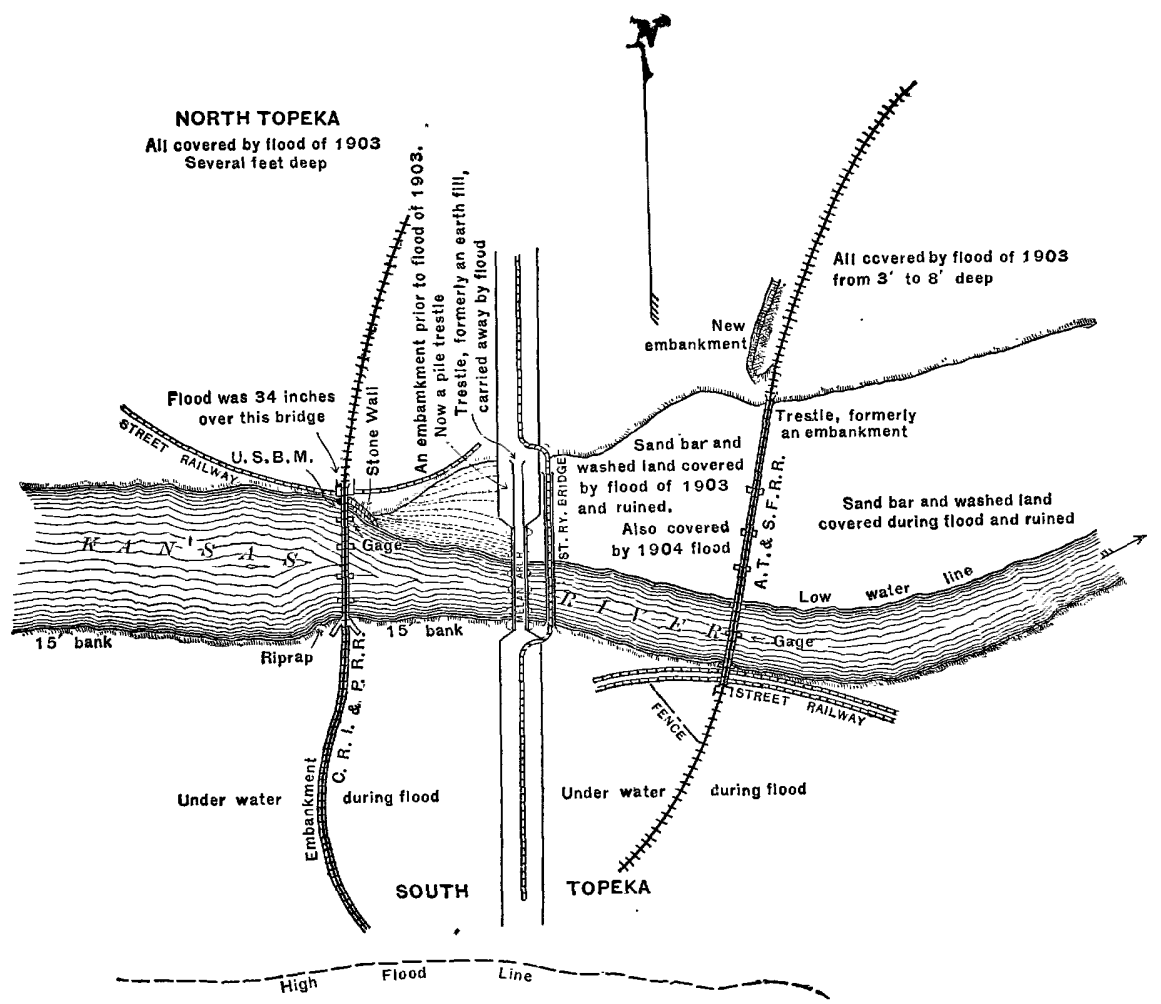

Frg. 8.--Kansas River and flooded area in vicinity of Melan arch bridge, Topeka, Kans.

very large area of the city flooded. It seems almost incredible that this city should have allowed a pile bridge to be built in this already restricfed part of the channel, and especially should have allowed a 


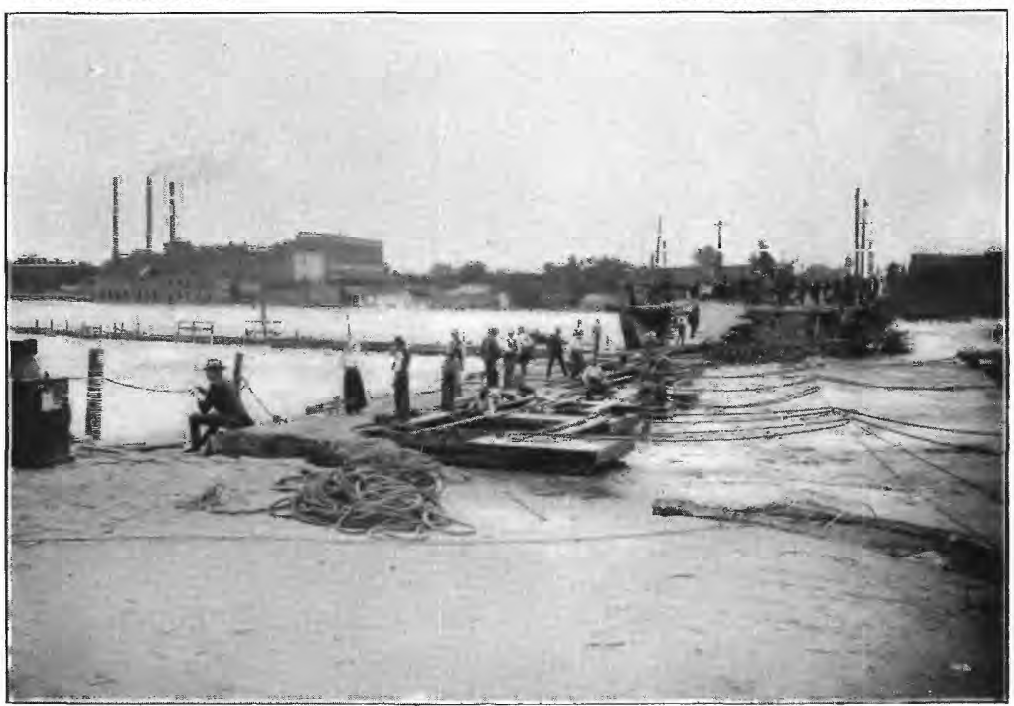

A. CHANNEL SCOURED BY KANSAS RIVER AROUND THE ABUTMENT OF THE MELAN BRIDGE, TOPEKA, KANS.

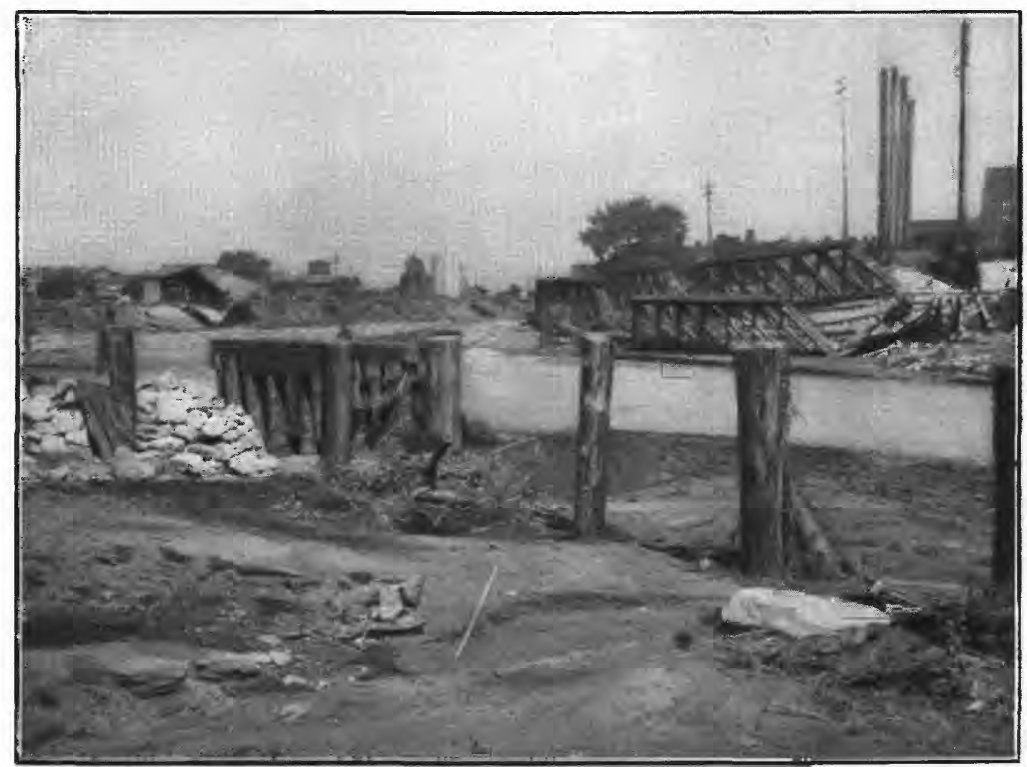

B. RUINS OF DENVER AND RIO GRANDE RAILWAY BRIDGE, TRINIDAD, COLO. 
second one to be built at this place after the complete destruction of the old pile bridge and of part of the Melan bridge. ${ }^{a}$

Fig. 8 shows the location of the bridges and gages at Topeka, a part of the flooded area, and depth of overflow. Topeka, like Lawrence, is located in a bend of the river, and duיing great floods the river cuts across these bends and floods large areas of lowland.

\section{FLOOD NEAR MANHATTAN, KANS.}

The daily gage heights and corresponding discharge of Blue River near Manhattan, Kans., during the flood of 1904 and also during that of 1.903 are given in the table on page 75 . It would seem that the flood reached its maximum stage on July 6 for a gage height of 22.8 feet and the discharge of 23,160 second-feet. This stage is 13 feet less and the discharge only about one-third of that during the 1903 flood at this place.

FLOOD NEAR JUNCTION, KANS.

The following readings of the United States Geological Survey gage on the highway bridge over Republican River at Junction show the fluctuations of the surface of this river during the June and July floods of 1904 .

Gage height, in feet, of Republican River at Junction, Kans., June 1't to July $11,1904$.

[Gage at highway bridge near pump house.]

\begin{tabular}{|c|c|c|c|c|c|}
\hline Date. & 9 a. m. & 4 p. m. & Date. & 9 a. $\mathrm{m}$. & 4 p. m. \\
\hline June 14 & 4.8 & 4.75 & June 28 & 9.2 & 8.8 \\
\hline June 15 & 4.4 & 8.6 & June 29 & 7.9 & 7.6 \\
\hline June 16 & 10.7 & 10.4 & June 30 & 7.6 & 7.2 \\
\hline June 17 & 8.9 & 8.4 & July 1 & 6.7 & 6.4 \\
\hline June 18 & \%.3 & 6.8 & July 2 & 6.1 & 6.0 \\
\hline June 19 & 6.4 & 5.8 & July 3 . . & 5.7 & 5.7 \\
\hline June 20 - & 5.4 & 5.5 & July 4 & $\tau .0$ & 6.7 \\
\hline June $\gtrsim 1$ & 5.6 & 5.7 & July 5 & 10.8 & 10.5 \\
\hline June 22. & 6.0 & 6.1 & July 6 & 10.0 & 9.8 \\
\hline June 23 & 6.1 & 5.7 & July T . . & 10.5 & 10.4 \\
\hline June 24 & 5.5 & 5.6 & July 8 & 10.1 & 9.1 \\
\hline June 25 & 11.8 & 12.3 & July 9 & 7.7 & 7.4 \\
\hline June 26 . & 13.0 & 12.7 & July 10 & 7.7 & 7.4 \\
\hline June 27 & 11.4 & 10.5 & July 11 & 6.4 & 6.4 \\
\hline
\end{tabular}

${ }^{a}$ Since the above was written two arches lave been added to the Melan steel-concrete arch bridge, thus increasing the channel width about 150 feet. The street-car bridge supported on piles has been replaced by a steel briage supported on metal piers placed directly back of the piers of the Melan bridoe. Levees are being built along the Kansas River and Soldier Creek to prevent overflow: 
These readings show that the highest water in July occurred on the 5th, the gage height being 10.8 feet, or about 7.4 feet less than the highest reading at this place in 1903. The June flood of 1904 was greater at this station than the July flood, the maximum gage reading being 13 feet on June 26 , as compared with 10.8 feet on July 5 . The flood of 1903 cut a shallow channel around the left approach to this bridge. The June flood of 1904 widened and deepened this new channel so that in August, 1904, it was about 180 feet wide and nearly as deep as the main channel. The flow in this new channel enters the main channel a short distance below the station, and has a marked retarding effect on the flow in the main channel.

The July flood on Smoky Hill River at Junction was much larger than that on Republican River. There is no gage on the Smoky Hill at this place, but from the high-water marks in Mr. Hogan's mill it is found that the crest of the July flood of 1904 was only 5 inches less than the crest of the flood in 1903. Nearly as much damage was done by the 1904 flood as by the earlier one, the water in 1904 appearing to have a greater velocity and a greater scouring effect than that of the 1903 flood. The macadamized road from the city to this mill was badly damaged by the scour.

FLOOD NEAR SOLOMON, KANS.

Fluctuations of the water surface at Solomon are shown by the following readings of the United States Geological Survey gage:

Gage height on Smoky Hill River at Solomon, Kans.. June and JuIy, 1.904.

\begin{tabular}{|c|c|c|c|c|c|}
\hline Date. & Time. & $\begin{array}{c}\text { Gage } \\
\text { height. }\end{array}$ & Date. & Time. & $\begin{array}{c}\text { Gage } \\
\text { height. }\end{array}$ \\
\hline \multirow{3}{*}{ June $4 \ldots . . . . .}$. & & Feel. & & & Feet. \\
\hline & 8 a. $\mathrm{m}_{-}$ & 15.5 & June 30 & \% p. m. & 15.1 \\
\hline & r p. m... & 17.4 & July 5 . & 10 a. $\mathrm{m} . .$. & 16.9 \\
\hline \multirow[t]{2}{*}{ June 5 . } & 10 a. $\mathrm{m} \ldots$ & 18.9 & July $6 \ldots$ & 11 a. $\mathrm{m} . .$. & 21.8 \\
\hline & 7 p. m..... & 19.8 & & 8.30 p. $\mathrm{m}_{-}$ & 23.9 \\
\hline \multirow[t]{2}{*}{ June 6} & 9.30 a. $\mathrm{m}$ & 21.1 & July 7 & 7.30 a. $\mathrm{m}$ & 25.4 \\
\hline & \%.30 p. m & 22.0 & & 6 p. m. & 26.4 \\
\hline \multirow[t]{2}{*}{ June $7 \ldots \ldots$} & 6 a. $\mathrm{m}$ & 22.6 & July 8 . . . & 8.30 a. $\mathrm{m}$ & $2 \tau .0$ \\
\hline & 7.30 p. $\mathrm{m}$ & 22.7 & & $8 \mathrm{p.m}$ & 27.5 \\
\hline June 8 & 11 a. $\mathrm{m} \ldots$ & 20.6 & Tuly 9 & 9 a. $\mathrm{m} \ldots$ & 27.8 \\
\hline \multirow[t]{2}{*}{ June $26 \ldots \ldots$} & 11.30 a. $\mathrm{m}$ & 19.5 & & 5 p. m $\ldots$ & 27.8 \\
\hline & 8 p. m. . . & 21.6 & July 10 . & 11 a. $\mathrm{m}$ & 27.9 \\
\hline \multirow{2}{*}{ June $97 \ldots$} & 7.30 a. $\mathrm{m}$. & 23.3 & & 8 p. m. . . & 27.9 \\
\hline & r p. m. . . & 23.6 & July 11 & 8 a. $\mathrm{m} \ldots$ & $2 \% .9$ \\
\hline \multirow[t]{2}{*}{ June $28 \ldots \ldots \ldots$} & 8 a. $\mathrm{m} \ldots$ & 23.0 & & 6.30 p. m & 27.9 \\
\hline & 8 p. $\mathbf{m}$ & 22.1 & July 12 & 6.30 a. $\mathrm{m}$ & $27 . \tau$ \\
\hline \multirow[t]{2}{*}{ June 29} & 7.30 a. $\mathrm{m}$ & 20.7 & July $13 \ldots$ & 7 a. m..... & 26.9 \\
\hline & 8 p. m. . & 19.3 & July $14 \ldots$ & 11 a. $\mathrm{m}$ & 25.0 \\
\hline June 30 & T a. $\mathrm{m} \ldots$ & 15.6 & July $15 \ldots$ & 11 a. $\mathrm{m} \ldots$ & 21.8 \\
\hline
\end{tabular}


The above records show that there were two rises in this river in June-one that reached a maximum on June 7, with a gage height of 22.7 feet, and the other that reached a maximum on $J$ une 27 , with a gage height of 23.6 feet. The July flood reached its maximum on July 10, for a gage height of 27.9 feet. The highest gage reading at this place in 1903 was 32.5 feet-that is, 4.6 feet higher than the highest reading in 1904 . The high water of 1904 only covered the highest bottom lands and did little damage as compared with that of 1903. This high water came mainly from Smoky and Saline rivers, Solomon River not being especially high.

\section{COMPARISON OF FLOODS OF 1903 AND 1904.}

From the table on page 67 and fig. 6 , page 68 , it is seen that Kansas River was flowing at a rate of 98,000 cubic feet per second or more for thirteen consecutive days in 1903 , and the discharge was greater than this on only two consecutive days in 1904. The maximum daily rate of discharge in 1903 was about $\tau 0$ per cent greater than that in 1904. The total volume discharged by the river for the thirteen days when the flow was greatest in 1903 was two and onehalf times more than for the thirteen days of greatest flow in 1904.

Gage height and discharge of Blue River near Manhattan. Kans., May 25 to June 8, 1903, and June 24 to July 17, 1904.

\begin{tabular}{|c|c|c|c|c|c|}
\hline Date. & $\begin{array}{c}\text { Gage } \\
\text { height. }\end{array}$ & Discharge. & Date. & $\begin{array}{c}\text { Gage } \\
\text { height. }\end{array}$ & Discharge. \\
\hline $\begin{array}{rr} & 1903 . \\
\text { May } 25 & \ldots \ldots\end{array}$ & $\begin{array}{l}\text { Feet. } \\
27.50\end{array}$ & $\begin{array}{c}\text { Sec.-feet. } \\
46,670\end{array}$ & $\begin{array}{r}1904 . \\
\text { June } 28 \ldots . .\end{array}$ & $\begin{array}{l}\text { Feet. } \\
11.90\end{array}$ & $\begin{array}{l}\text { Sec.-feet. } \\
7,020\end{array}$ \\
\hline May 26 & 25.00 & 40,170 & June 39. & 10.10 & 4,800 \\
\hline May 27 & 30.50 & 54,470 & June 30 & 15.60 & 12,360 \\
\hline May 28 & 32.00 & $58,3 \% 0$ & July 1 & 14.60 & 10,860 \\
\hline May 29 & $a 33.50$ & 62,270 & July 2 . & 10.40 & 5,150 \\
\hline May 30 & a 34.80 & 65,650 & July 3 & 9.10 & 3,730 \\
\hline May 31 & $a 36.00$ & 68,770 & July 4 & 10.60 & 5,380 \\
\hline June $1 \ldots$ & $a 35.00$ & 66,170 & July 5 . & 12.60 & 7,980 \\
\hline June $2 \ldots$ & a 33.80 & 63,050 & July 6 & 22.80 & 23,160 \\
\hline June 3 & 32.50 & 59,670 & July $\gamma \ldots$ & 19.90 & 18,810 \\
\hline June 4 & 30.00 & 53,170 & July 8 . - & 17.90 & 15,810 \\
\hline June 5 . & 27.00 & 45,370 & July 9 & 16.00 & 12,960 \\
\hline June 6 . & 25.50 & 41,470 & July 10 & 14.80 & 11,160 \\
\hline June $r$ & 21.50 & 23,900 & July 11 & 13.40 & 9,100 \\
\hline June 8 & 17.50 & 15,900 & July 12 & 12.40 & 7,700 \\
\hline 1904. & & & July 13 & 12.70 & 8,120 \\
\hline June 24 & 8.30 & 2,970 & July 14 & 11.40 & 6,360 \\
\hline June 25. & 15.20 & 11,660 & July 15 & 10.50 & 5,260 \\
\hline June 26 . & 15.10 & 11,510 & July $16 \ldots$ & 9.80 & 4,470 \\
\hline June $2 \tau$. & 12.50 & $\tau, 840$ & July 17 & 9.50 & - 4,140 \\
\hline
\end{tabular}

a Maximum gage height, 36.50 feet. 
From the preceding table it can be seen that the Blue, near Manhattan, was discharging at the rate of 40,000 second-feet or more for thirteen consecutive days in 1903, while at no time during the flood of 1904 was the flow of this river 24,000 cubic feet per second. The maximum daily rate in 1903 was 68,770 second-feet, and in 1904 it was 23,160 second-feet.

The Smoky Hill at Ellsworth had a maximum daily flow of more than 3,000 second-feet on six days in 1908 , but reached that amount on only three days in 1904 .

Gage height and aischarge of Smoky Hill River at Ellsuroith, Kans.. May 25 to June s. 1903, and June :2 to July 16. 190'-'.

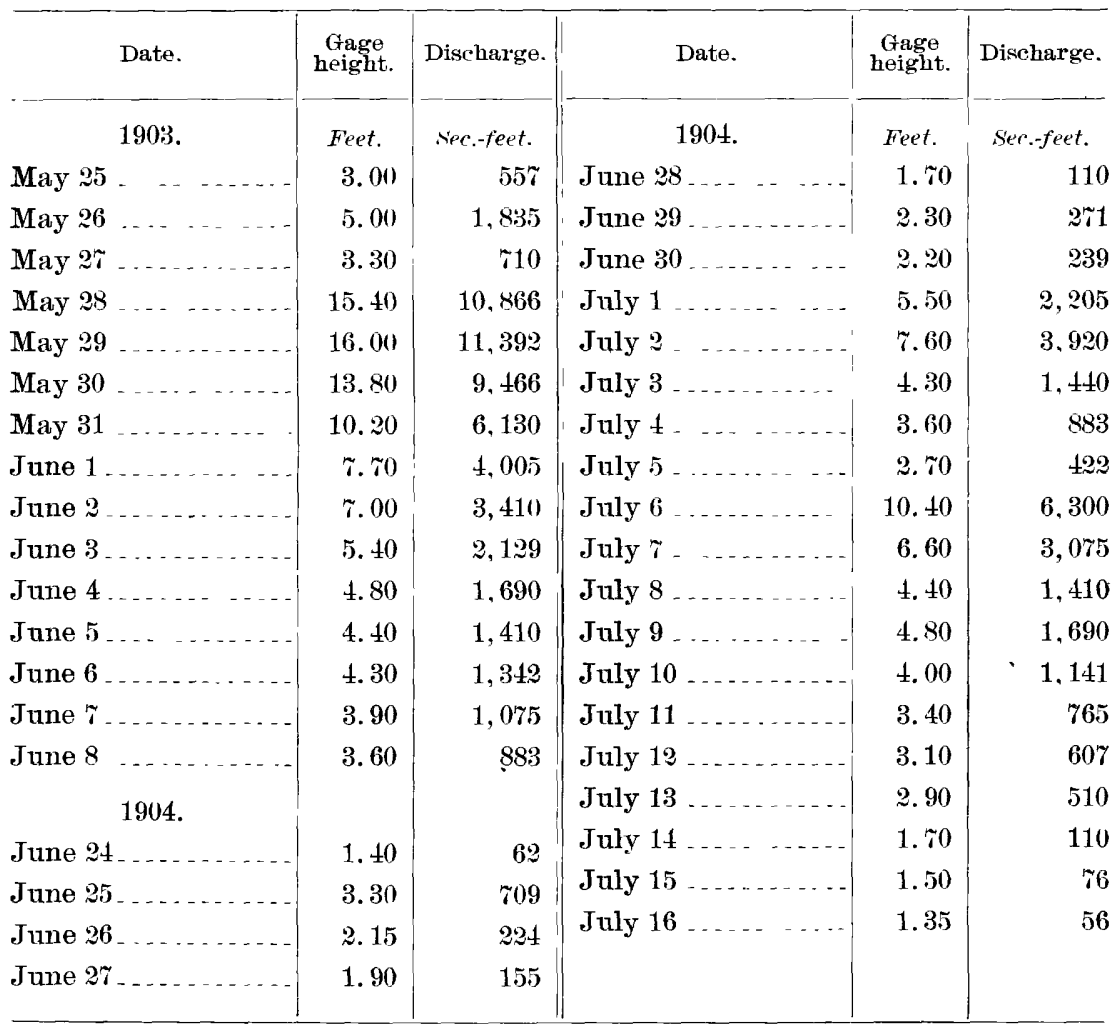

\section{DAMAGE DONE BY FLOOD.}

The damage caused by the 1904 flood along Kansas River was very much less than by the flood of 1903 . This was due to three causes: First, the flood height was from 5 to 8 feet greater in the 1903 flood than in that of 1904 , and consequently the area submerged was very much greater. The areas submerged in Kansas City during these floods are shown in Pl. V (p. 6t). Second, the property in the over- 
flow area, especially in the cities, was less in 1904 than in 1903 . Only a few of the buildings that were swept away or destroyed by the 1903 flood were replaced. Third, the people living along this stream heeded promptly the warnings of the approach of a flood issued by the United States Weather Bureau in 1904 and conveyed movable property out of reach of the waters.

The crops on the low land along the river were destroyed, and the lateness of the flood prevented the maturing of a second crop; in this respect the 1904 flood was more injurious to farmers than that of 1903. Some of the best corn raised in Kansas in 1903 was raised on the bottom land along the Kansas that was overflowed in the May flood of that year.

Very few bridges were destroyed in the 1904 flood, and the damage to railroads along this river was comparatively small. J. C. Bye, resident engineer of the Union Pacific Railroad at Kansas City, stated to the writer that the loss sustained by the Union Pacific Railroad Company along this river was about $\$ 1,250,000$ in the 1903 flood and about $\$ 75,000$ in the 1904 flood, or only about 6 per cent of the former. This percentage probably represents approximately the losses of the other railroads doing business in Kansas River Valley during these floods.

The loss, risk, and inconvenience suffered by the cities and towns along the river for lack of water for drinking and fire purposes, and the lack of illuminating gas, electric light, and power was very small during the $190 \pm$ flood as compared with that of 1903.

PREVENTION OF FUTURE DAMAGE.

The remedy for overflow and damage resulting therefrom along this river, as stated in the flood report in 1903, is the rapid removal of the flood water from the drainage basin and the protection by levees of the lowlands from overflow. The natural width of the river of about 850 feet has been reduced to 600 feet in many places, and in one place to 420 feet; that is, by more than 50 per cent of its width. The bridges are constructed on piers founded on piles with rock filling around them that prevent the natural deepening of the channel during a flood. A greater number of piers are used than is necessary; and against these piers drift collects, forming a dam that retards the flow of the stream and causes overflow of the lowlands. The channel in places, notably Kansas City and Topeka, is more or less clogged with wreckage.

The measures declared necessary by the board of army engineers for preventing the recurrence of another flood of the magnitude of 
that in 1903 (see pp. 65-66) are expensive. Many important industries have been allowed to locate on the banks of this river and encroach in its natural width. To condemn land on each side of the stream in the cities sufficient to restore to the stream its natural width would destroy these industries. The building of masonry walls on cach side of the stream through Kansas City and the necessary elevation of bridges to the height of these walls will necessitate the raising of all the railroads in the low part of Kansas City and will be very expensive.

Instead of widening the channel to its original dimensions it is suggested that an overflow channel be constructed to carry the flood waters past Kansas City. This, however, is simply a detail. The remedy for overflow is sufficiently clear, namely, an additional waterway sufficient to carry off floods. The most satisfactory and economical means of securing this additional waterway is a local problem that requires much study.

\section{NEOSHO RIVER FLOODS.}

The 1904 floods on Neosho River were greater in number, height, and destructiveness than ever known before on this stream. The flood of 1885 was the largest prior to that of 1904. Although there are no definite records of the height reached by the 1904 flood, there are quite a number of well-defined flood marks along the river, which show that the crest of the flood of July 10, 1904, reached a height of about 1 foot greater than that of the 1885 flood.

\section{STREAMS AND DRAINAGE BASIN.}

Neosho River rises in the northern part of Morris County, Kans., flows in a southeasterly and southerly direction thirough Kansas and Indian Territory, and empties into Arkansas River near Fort Gibson, Ind. T. In a direct course this river has a length of about 260 miles, but the distance along the bed is much greater, as this is very crooked. It falls, in a distance of about 136 miles, from an elevation of about 1.500 feet near its source to 800 feet at a point about 27 miles north of the Kansas-Indian Territory line, and from this point to the mouth, a distance of 110 miles in a straight line, it falls about 300 feet. It drains a long, narrow stretch of land just east of Verdigris River and west of Osage and White rivers. A profile of the river obtained from the atlas sheets of the United States Geological Survey is as follows: ${ }^{a}$

${ }^{a}$ Water-Sup. and Irr. Paper No. 44, U. S. Geol. Survey, 1901, p. 66. 
Elevations on Neosho River.

\begin{tabular}{|c|c|c|c|}
\hline Locality. & $\begin{array}{c}\text { Distance } \\
\text { from mouth } \\
\text { in miles. }\end{array}$ & $\begin{array}{l}\text { Height } \\
\text { above sea in } \\
\text { feet. }\end{array}$ & $\begin{array}{c}\text { Fall per } \\
\text { mile in feet. }\end{array}$ \\
\hline \multirow[t]{2}{*}{ Mouth } & 0 & $4 \% 0$ & - . . \\
\hline & 12 & 500 & 2.5 \\
\hline \multirow[t]{2}{*}{ Markham Ferry, Ind. T. . . . } & 42 & 550 & $1 . \%$ \\
\hline & 69 & 600 & 1.8 \\
\hline \multirow[t]{2}{*}{ Above Oswego, Kans :- } & $17 \%$ & 800 & 1.8 \\
\hline & 206 & 850 & 1.7 \\
\hline Humboldt, Kans .. & 298 & 900 & 2.3 \\
\hline Leroy, Kans . . . . . . . . . & 255 & 950 & 1.8 \\
\hline Ottumwa, Kans. & $2 \% 4$ & 1,000 & 2.6 \\
\hline \multirow[t]{2}{*}{ Emporia, Kans } & 296 & 1,050 & 2.3 \\
\hline & 310 & 1,100 & 3.6 \\
\hline Council Grove, Kans & 326 & 1,200 & 6.25 \\
\hline Head ............ & 346 & 1,500 & 15.0 \\
\hline
\end{tabular}

As compared with the Verdigris, Neosho River rises about 40 miles farther north and at about 100 feet greater elevation. They flow in nearly parallel directions and empty into Arkansas River only a few hundred feet apart. The Verdigris falls more rapidly in its upper course than the Neosho, reaching the State line at an elevation of 680 feet, falling 790 feet in about 151 miles. The Neosho falls more gradually, reaching the State line at an elevation of about 7 i 0 feet, falling 730 feet in about 267 miles. From the State line the Neosho falls about 270 feet and the Verdigris about 180 . As a result of these differences in the topography of the watershed, the Verdigris flow's in a narrow, deep channel while the Neosho is wider, has low er banks, and is subject to overflow in many places, notably near Chanute, Kans. Near the mouth the differences are more marked. The Verdigris is deeper, 250 feet wide, and sluggish, with scarcely a perceptible current at ordinary stage of water. The Neosho is from 600 to 800 feet wide, is shallow, and has a fairly rapid velocity.

The principal tributaries of the Neosho are the Cottonwood, which enters it from the west near Emporia, and Spring River, which enters it from the east a little south of the Kansas line.

The area of land flooded along this river is large compared with the size of the stream. This, in fact, is true of all the streams in the southeastern part of Kansas. They have little fall and are very crooked. The water, instead of running off quickly, is held 
back, overflows the banks, spreads out over the river bottom to a width in places of from 4 to 5 miles. The average fall of the stream from Emporia to the mouth is less than 2 feet per mile, and there are stretches of 20 miles where the fall is only 1.7 feet per mile.

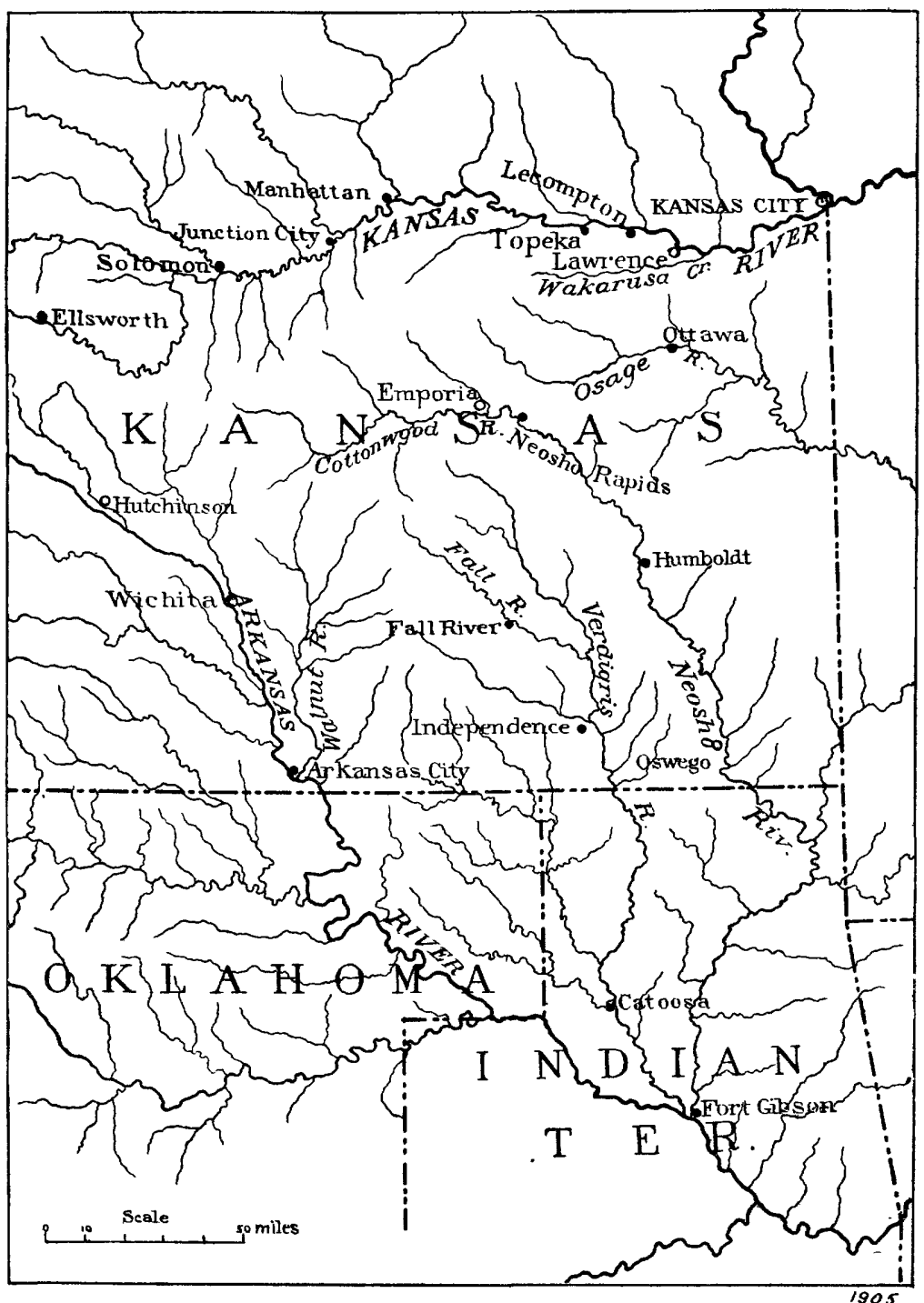

FIG. 9.-Drainage basins of southeastern Kansas.

'There are stretches of 10 miles where the river is so crooked that the length, measured along the river, is more than twice that in a direct course. These numerous bends, together with the trees that grow thickly to the water's edge in some places, reduce the already 
small slope of the stream so much that its effective value is probably not more than $1 \frac{1}{4}$ feet per mile.

The upper part of the watershed is hilly pasture land, from which the water flows rapidly. The central and lower part is rolling cultivated land. There are no forests on the watershed, but narrow strips of trees are found along the greater part of the stream.

\section{DISCHARGE AND RUN-OFF,}

A gaging station was established on this stream August 1, 1895, at a highway bridge about 1 mile west of Iola, a short distance below a dam. The channel is straight for several hundred feet above and below the station, and the bed, though stony, is quite permanent. Both banks are low and subject to overflow during flood, especially the right one. The following table gives the maximum and minimum gage height and corresponding discharge for the years-1896 to 1903that this station was in operation. The maximum flow is seen to be very large and the minimum flow very small. For sixty days in 1896 and for one hundred and twenty days in 1897 the stream was almost dry, the discharge being only 1 cubic foot per second.

Estimated monthly discharge of Neosho River at Iola, Kans.

[Drainage area, 3,670 square miles.]

\begin{tabular}{|c|c|c|c|c|c|c|}
\hline \multirow[b]{2}{*}{ Month. } & \multicolumn{3}{|c|}{ Discharge in second-feet. } & \multirow[b]{2}{*}{$\begin{array}{l}\text { Total in } \\
\text { acre-feet. }\end{array}$} & \multicolumn{2}{|c|}{ Run-off. } \\
\hline & $\begin{array}{l}\text { Maxi- } \\
\text { mum. }\end{array}$ & $\begin{array}{l}\text { Mini- } \\
\text { mum. }\end{array}$ & Mean. & & $\begin{array}{l}\text { Depth in } \\
\text { inches. }\end{array}$ & $\begin{array}{l}\text { Second- } \\
\text { feet per } \\
\text { square } \\
\text { mile. }\end{array}$ \\
\hline 1896. & & & & & & \\
\hline January -. & 275 & 100 & 125 & 7,686 & 0.03 & 0.03 \\
\hline February & 275 & 75 & 114 & 6,557 & .03 & .03 \\
\hline March $\ldots .$. & 125 & 20 & 61 & 3,751 & .02 & .02 \\
\hline April & 15,025 & 50 & 2,708 & 161,137 & .82 & .74 \\
\hline May - . - & 45,560 & 160 & 10,273 & 631,666 & 3.23 & 2.80 \\
\hline June . . . & 5,048 & 250 & 905 & 53,851 & .28 & .25 \\
\hline July .... & 7,890 & 125 & 1,278 & 78,581 & .40 & .35 \\
\hline August & 300 & 10 & 58 & 3,566 & .02 & .02 \\
\hline September & 10 & 0 & 6 & 357 & .002 & .002 \\
\hline October $\ldots \ldots$ & 225 & 0 & 11 & 676 & .003 & .003 \\
\hline November & 2,290 & 5 & 245 & $14,5^{\prime} 78$ & .07 & .07 \\
\hline December $\ldots . . . . .$. & 445 & 20 & 88 & 5,411 & .02 & .02 \\
\hline The year . & 45,560 & 0 & 1,322 & 967,817 & 4.925 & .36 \\
\hline
\end{tabular}

IRR $147-05 \mathrm{M}-6$ 
Estimated monthly discharge of Neosho River at Iola, Kans.-Continued.

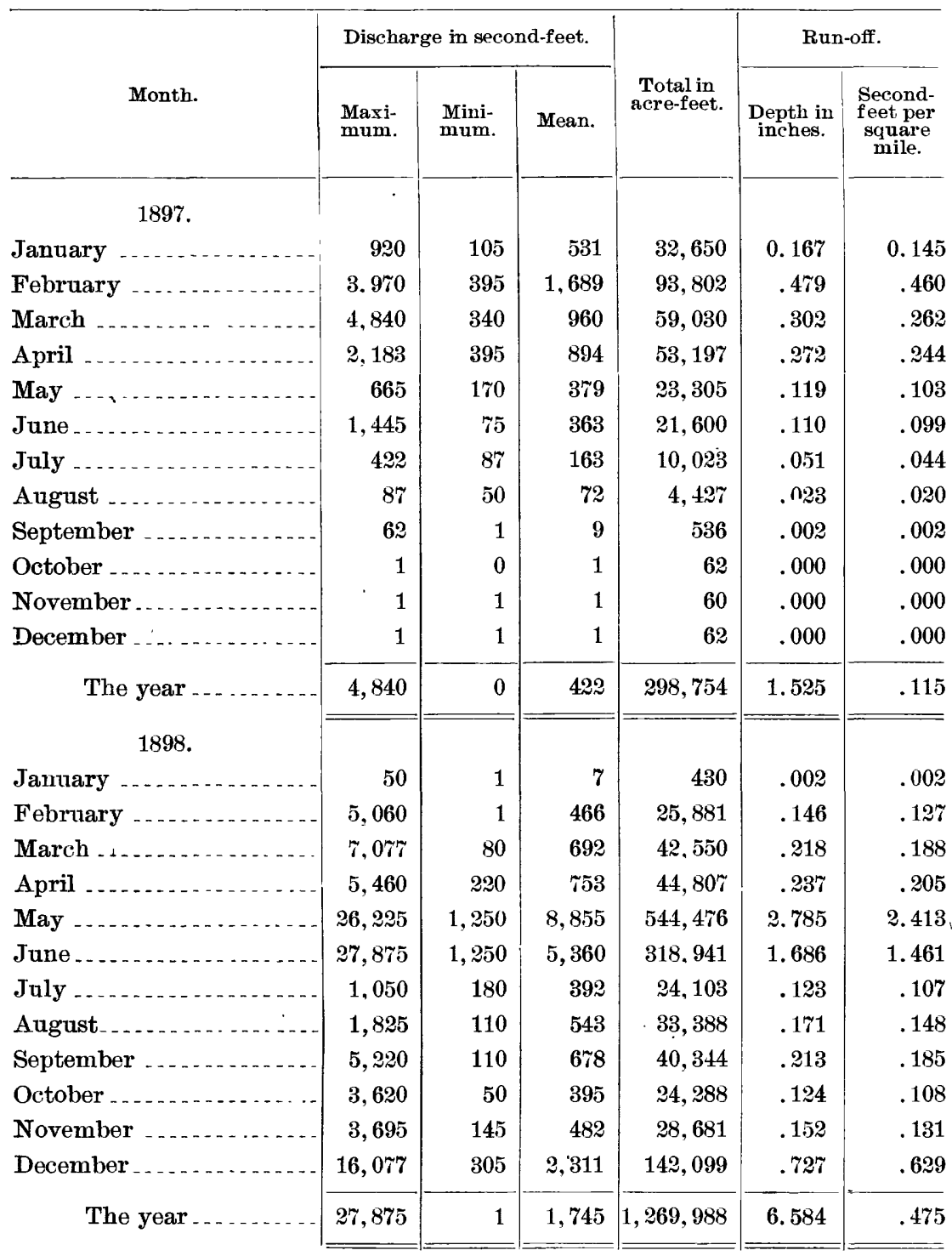


Estimated monthly discharge of Neosho River at Iola, Kans.-Continued.

\begin{tabular}{|c|c|c|c|c|c|c|}
\hline \multirow[b]{2}{*}{ Month. } & \multicolumn{3}{|c|}{ Discharge in second-feet. } & \multirow[b]{2}{*}{$\begin{array}{l}\text { Total in } \\
\text { acre-feet. }\end{array}$} & \multicolumn{2}{|c|}{ Run-off. } \\
\hline & $\begin{array}{l}\text { Maxi- } \\
\text { mum. }\end{array}$ & $\begin{array}{l}\text { Mini- } \\
\text { mum. }\end{array}$ & Mean. & & $\begin{array}{c}\text { Depth in } \\
\text { inches. }\end{array}$ & $\begin{array}{l}\text { Second- } \\
\text { feet per } \\
\text { square } \\
\text { mile. }\end{array}$ \\
\hline 1899. & & & . & & & \\
\hline January . . . & 450 & 305 & 357 & 21.951 & 0.12 & 0.10 \\
\hline February & 4,020 & 220 & $61 \%$ & 34,266 & .18 & .17 \\
\hline March .... & 12,290 & 780 & 2.138 & 131,461 & 67 & .58 \\
\hline April . & 1,825 & 505 & 887 & 52,780 & .27 & .24 \\
\hline May & 5,620 & 282 & 1,094 & 67,268 & .35 & .30 \\
\hline June . . & 22,191 & 350 & 4,168 & 248,013 & 1.27 & 1.14 \\
\hline July .... & 21,365 & 305 & 3,443 & 211,703 & 1.08 & .94 \\
\hline August. & 630 & 220 & 308 & 18,938 & .09 & .08 \\
\hline September. & 305 & 180 & 200 & 11,901 & .06 & .05 \\
\hline October & 145 & 50 & 98 & 6,026 & .03 & .03 \\
\hline November. . . . . & 50 & 50 & 50 & 2,975 & .01 & .01 \\
\hline December ........ & 110 & 50 & 75 & 4,612 & .02 & .02 \\
\hline The year & 22,191 & 50 & 1,120 & 811,894 & 4.15 & .31 \\
\hline 1900. & & & & & & \\
\hline January ..... & 192 & 145 & 179 & 11,006 & .06 & .05 \\
\hline February & 292 & 192 & 200 & 11,107 & .05 & .05 \\
\hline March . . . . . & 10,412 & 292 & 2,604 & 160,114 & .82 &.$\pi 1$ \\
\hline April & 9,800 & 338 & 2,229 & 132,635 & .68 & .61 \\
\hline May & 23,700 & 385 & 4,098 & 251,976 & 1.29 & 1.12 \\
\hline June . & 4,725 & 256 & 1,061 & 63,134 & .32 & $\therefore 29$ \\
\hline July . . . & 4,025 & 292 & 766 & 47,099 & .24 & .21 \\
\hline Angust & 650 & 145 & 201 & 12,359 & .06 & .05 \\
\hline September & 15,350 & 145 & 2,025 & 120,496 & .61 & .55 \\
\hline October ....... & 13,950 & 338 & 2,019 & 124,143 & $\because .63$ & .55 \\
\hline November & 30,411 & 510 & 3,418 & 203,385 & 1.04 & .93 \\
\hline December .... . & 650 & 292 & 382 & 23,488 & .12 & .10 \\
\hline The year & 30,411 & 145 & 1,598 & $1,160,942$ & 5.92 & .43 \\
\hline
\end{tabular}


Estimated monthly discharge of Neosho River at Iola, Kans.-Continued.

\begin{tabular}{|c|c|c|c|c|c|c|}
\hline \multirow[b]{2}{*}{ Month. } & \multicolumn{3}{|c|}{ Discharge in second-feet. } & \multirow[b]{2}{*}{$\begin{array}{l}\text { Totel in } \\
\text { acre-feet. }\end{array}$} & \multicolumn{2}{|c|}{ Run-off. } \\
\hline & $\begin{array}{l}\text { Maxi- } \\
\text { mum. }\end{array}$ & $\begin{array}{l}\text { Mini- } \\
\text { mum. }\end{array}$ & Mean. & & $\begin{array}{l}\text { Depth in } \\
\text { inches. }\end{array}$ & $\begin{array}{l}\text { Second- } \\
\text { feet per } \\
\text { square } \\
\text { mile. }\end{array}$ \\
\hline 1901. & & & & & & \\
\hline January . . . & 985 & 353 & 444 & 27.300 & 0.140 & 0.121 \\
\hline February & 3.570 & 353 & 1,224 & 67,978 & .348 & .334 \\
\hline March . & 1,900 & 552 & 999 & 61,426 & .314 & .272 \\
\hline April ..... & 19,250 & 1,382 & 6,969 & 414,684 & 2.119 & 1.899 \\
\hline May ........ & 1.500 & 678 & 1,065 & 65,484 & .334 & .290 \\
\hline June . . - & 4,250 & 450 & 955 & 56,826 & .290 & .260 \\
\hline July .... & 353 & 190 & 254 & 15,618 & .080 & .069 \\
\hline August & 190 & 154 & 178 & 10,945 & .055 & .048 \\
\hline September & 142 & 58 & 102 & 6,069 & .031 & .028 \\
\hline October .... & 58 & 10 & 33 & 2,029 & .010 & .009 \\
\hline November .... & ro & 10 & 32 & 1,904 & .010 & .009 \\
\hline December .... & 94 & 10 & 35 & 2,152 & .012 & .010 \\
\hline The year. & 19,250 & 10 & 102 & 732,415 & 3.743 & .279 \\
\hline 1902. & & & & - & & \\
\hline January - . & 467 & 190 & 370 & 22,750 & .12 & .10 \\
\hline February & 1,000 & 445 & 549 & 30,470 & .16 & .15 \\
\hline March _.. & 1,400 & 445 & 601 & 36,954 & .18 & .16 \\
\hline April .... & 4,900 & 490 & 836 & 49,745 & .26 & .23 \\
\hline May .... & 18,500 & 490 & 5,585 & 343,408 & 1.75 & 1.52 \\
\hline June .... & 35,550 & 2,000 & 11,694 & 695,841 & 3.56 & 3.19 \\
\hline July .... & 6,690 & 925 & 2,169 & 133,367 & .68 & .59 \\
\hline Angust . & 24,550 & 330 & 6,382 & 392,414 & 2.01 & 1.74 \\
\hline September & 18,500 & 580 & 4,962 & 295,259 & 1.51 & 1.35 \\
\hline October & 20,150 & 850 & 4,689 & 288,315 & 1.48 & 1.28 \\
\hline November . ... & 2,600 & 580 & 1,119 & 66,585 & .33 & .30 \\
\hline December .. - & 7,500 & 925 & 2,227 & 136,933 & .70 & .61 \\
\hline The year & 35,550 & 190 & 3,432 & $2,492,041$ & 12.74 & .94 \\
\hline
\end{tabular}


Estimated monthly discharge of Neosho River at Iola, Kans.-Continued.

\begin{tabular}{|c|c|c|c|c|c|c|}
\hline \multirow[b]{2}{*}{ Month. } & \multicolumn{3}{|c|}{ Discharge in second-feot. } & \multirow[b]{2}{*}{$\begin{array}{l}\text { Total in } \\
\text { acre-feet. }\end{array}$} & \multicolumn{2}{|c|}{ Run-off. } \\
\hline & $\begin{array}{l}\text { Maxi- } \\
\text { mum. }\end{array}$ & $\begin{array}{l}\text { Mini- } \\
\text { mum. }\end{array}$ & Mean. & & $\begin{array}{l}\text { Depth in } \\
\text { inches. }\end{array}$ & $\begin{array}{l}\text { Second- } \\
\text { feet per } \\
\text { square } \\
\text { mile. }\end{array}$ \\
\hline 1903. & & & & & & \\
\hline January & $7 \% 0$ & 530 & 646 & 39.721 & 0.21 & 0.18 \\
\hline February & 8,490 & 350 & 1.041 & 57,814 & .29 & .28 \\
\hline March & 9,390 & $7 \% 0$ & 2,109 & 135,211 & .69 & .60 \\
\hline April & 11,634 & 580 & 2.208 & 131,385 & .67 & .60 \\
\hline May . . . & 29,670 & 580 & 9,157 & 563,042 & 2.88 & 2.50 \\
\hline June . . . & 39,120 & 1,190 & 10,725 & 638,182 & 3.26 & 2.92 \\
\hline July - . - & 3,990 & $701)$ & 1,123 & 69,051 & .36 & .31 \\
\hline August & 19,210 & 630 & 6,112 & 375,812 & 1.91 & 1.66 \\
\hline September & 14,010 & 120 & 1,396 & 83,068 & .42 & .38 \\
\hline October & 14,220 & 120 & 1.974 & $121,3 \pi 6$ & .62 & .54 \\
\hline November & 19,210 & 700 & 4,246 & 252,654 & 1.29 & 1.16 \\
\hline
\end{tabular}

NuTE.- Gage heights for 1898 are given in Watcr-Supply and Irrigation Paper No. 28, page 115 ; discharge measurements. page 116 ; rating table, page 117 .

Gage heights and discharge measurements for 1899 are given in Water-Supply Paper No. 57, page 267: rating table in Paper No. 39, page 450.

Gage heights and discharge measurements for 1900 are given in Water-Supply Paper No. 50 , page 332; rating table in Paper No. 52, page 518.

Gage heights and discharge measurements for 1901 are given in Water-Supply Paper No. 66 , page 57 ; rating table on page 172 of same paper.

\section{FLOOD NEAR IOLA, KANS.}

Flood-gaging stations were established on this stream at Neosho Rapids and Humboldt by the United States Geological Survey and at Iola by the United States Weather Bureau in the spring of 1904 . From the gage readings at these places the duration and magnitude of the floods on this river can be seen. The gage at Iola is just above a dam and does not show the same range of stage as did the old United States Geological Survey gage, which was just below this dam. The highest reading in 1903 was 13 feet 8 inches on July 4 . The highest reading in 1904 was 15.2 feet on July 10. From the high-water marks at the bridge it appears that the reading of the old United States Geological Survey gage on July 10, 1904, was about 24 feet, or 22 feet above ordinary low water. The tables following give the gage readings and discharges at Iola. 
Maximum and minimum discharge of Neosho River at Iola, Kans.

[Drainage basin, 3,670 square miles.]

\begin{tabular}{|c|c|c|c|c|c|c|c|c|}
\hline \multirow{2}{*}{ Year. } & \multirow{2}{*}{ Date. } & \multirow{2}{*}{$\begin{array}{c}\text { Gage } \\
\text { height } \\
\text { in feet. }\end{array}$} & \multicolumn{2}{|c|}{$\begin{array}{l}\text { Maximum dis- } \\
\text { charge in second- } \\
\text { feet. }\end{array}$} & \multirow{2}{*}{ Date. } & \multirow{2}{*}{$\begin{array}{c}\text { Gage } \\
\text { height } \\
\text { in feet. }\end{array}$} & \multicolumn{2}{|c|}{$\begin{array}{l}\text { Minimum dis- } \\
\text { charge in } \\
\text { second-feet. }\end{array}$} \\
\hline & & & $\begin{array}{c}\text { From } \\
\text { total } \\
\text { drainage } \\
\text { area. }\end{array}$ & $\begin{array}{c}\text { Per } \\
\text { square } \\
\text { mile. }\end{array}$ & & & $\begin{array}{c}\text { From } \\
\text { total } \\
\text { drain- } \\
\text { agearea }\end{array}$ & $\begin{array}{l}\text { Per } \\
\text { square } \\
\text { mile. }\end{array}$ \\
\hline 1895 & Sept. 12 & 21.00 & & & October & 2.03 & & \\
\hline 1896 & May 24 & 21.10 & 45,560 & 12.4 & $\begin{array}{l}\text { September and } \\
\text { October. }\end{array}$ & 2.00 & 0 & 0 \\
\hline 1897 & Mar. 5 & 6.35 & 4,840 & 1.32 & October & 1.70 & 0 & 0 \\
\hline 1898 & June 27 & 20.50 & 27,875 & 7.60 & $\begin{array}{c}\text { January and } \\
\text { February. }\end{array}$ & 1.80 & 1 & 0.00027 \\
\hline 1899 & June 9 & 17.03 & 22,191 & 6.05 & $\begin{array}{c}\text { October and } \\
\text { December. }\end{array}$ & 2.00 & 50 & .014 \\
\hline 1900 & Nov. 2 & 18.95 & 30,411 & 8.29 & $\begin{array}{l}\text { January, Au- } \\
\text { gust, and Sep- } \\
\text { tember. }\end{array}$ & 2.10 & 145 & .040 \\
\hline 1901 & Apr. 17 & 13.30 & 19,250 & 5.25 & $\begin{array}{l}\text { October and } \\
\text { December. }\end{array}$ & .50 & 10 & .0027 \\
\hline 1902 & June 11 & 21.25 & $a 35,550$ & 9.69 & January L...... & 2.00 & 190 & .052 \\
\hline 1903 & June 3 & 22.00 & $x 39,120$ & 10.7 & $\begin{array}{l}\text { September and } \\
\text { October. }\end{array}$ & 2.00 & 120 & .033 \\
\hline 1904 & July 10 & 24.00 & 74,600 & 20.33 & 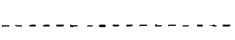 & & & \\
\hline
\end{tabular}

a Probably too small on account of overflow of banks.

Mean daily gage height of Neosho River at Iola, Kans., July 1-20, 1904.

[Weather Bureau record.]

\begin{tabular}{|c|c|c|c|}
\hline Date. & $\begin{array}{l}\text { Height in } \\
\text { feet. }\end{array}$ & Date. & $\begin{array}{c}\text { Height in } \\
\text { feet. }\end{array}$ \\
\hline July $1 \ldots$ & 11.4 & July 11 & 14.7 \\
\hline July $2 \ldots$ & 9.5 & July 12 & 14.0 \\
\hline July $3 \ldots$ & 3.7 & July 13 & 13.2 \\
\hline July $4 \ldots$ & 4.2 & July 14 & 13.0 \\
\hline July 5 & 4.2 & July $15 \ldots$ & 12.6 \\
\hline July $6 \ldots$ & 11.0 & July $16 \ldots$ & 10.5 \\
\hline July $\%$. & 12.6 & July $1 \%$ & 3.3 \\
\hline July 8 _ & 13.8 & July 18 & 2.9 \\
\hline July 9 . & 14.96 & July $19 \ldots$ & 2.2 \\
\hline July $10 \ldots$ & 15.2 & July $20 \ldots$ & 1.8 \\
\hline
\end{tabular}

The gage readings show that the flood at Iola lasted from July 6 to 16 , and reached a maximum stage of 15.2 feet on July 10 for an estimated discharge of about 74,600 cubic feet per second, 34,600 cubic feet of which was overflow. This estimate of the discharge is necessarily very roughly approximated, as no measurements of velocity were made. It was necessary to estimate the velocity of 
the overflow from the amount of scour on the roadbed of the Missouri Pacific Railway. This railroad crosses the valley on an embankment. The flood passed over this embankment on both sides of the river and had a width of about $1 \frac{1}{2}$ miles on the right bank and a width of about one-half mile on the left bank. The maximum depth, from actual measurement of the water above the surface of the rail, was 4 feet at the deepest place. The stone ballast of the road was badly washed ont in places, and the track was saved from washing away only by being held down. Trains could not cross the river for several days and passengers were taken across in buats.

FLOOD NEAR HUMBOLD'T, KANS.

A flood-gaging station was established at the highway bridge at Humboldt in April, 1904. The fluctuations of the surface, measured with a chain gage, are given below:

Gage height, in feet, of Neosho River at Humboldt. Kans.. April 23. to 25 and May 6 to July, 1904 .

\begin{tabular}{|c|c|c|c|c|c|}
\hline Date. & Time. & Height. & Date. & Time. & Height. \\
\hline & & Feet. & & & Feet. \\
\hline April 23 & 5 p. m. . & 3 & May $2 \%$ & 7 a. m. & 9 \\
\hline \multirow[t]{3}{*}{ April $24 \ldots$} & $6.10 \mathrm{a} . \mathrm{m}$ & 25.1 & & 8 p. m & 10 \\
\hline & 8.25 a.m. & 25.5 & May 28 & 8 a. $\mathrm{m}_{-}$ & 11 \\
\hline & $6 \mathrm{p.m}$ & 27.2 & & 7.10 p.m. & 11.9 \\
\hline \multirow[t]{4}{*}{ April 25 . } & 1 a. m... & $2 \% .3$ & May 29 & 10 a. $\mathrm{m}_{-}$ & 11 \\
\hline & 3 a. m... & $2 \gamma$ & & 8 p. m....... & 10.9 \\
\hline & $7 \mathrm{p} . \mathrm{m}_{-}$ & 20 & May 30 & 10.40 a.m & 15.7 \\
\hline & 1 p. $\mathrm{m}_{-}$ & 25.7 & & 8 p. m. . . & 18 \\
\hline May 6 & 6 p. m. & 11 & May 31 & 6.30 a. m... & 19 \\
\hline May $\tau \ldots$ & T p. m. . & 13 & & 10 p. m. & 19.9 \\
\hline May $8 \ldots$ & $10.30 \mathrm{a} . \mathrm{m}$ & 11.9 & June 1 & 7 a. $\mathrm{m}$ & 20.4 \\
\hline \multirow[t]{2}{*}{ May $16 \ldots$} & 1.30 p. m & 13.2 & & 7.30 p.m. & 21.6 \\
\hline & 5.30 p. m & 15 & June 2 & 8 a. m. & 22.4 \\
\hline \multirow[t]{2}{*}{ May $1 \%$. } & $7.30 \mathrm{a} . \mathrm{m}$ & 18.5 & & 6 p. m. & 23.5 \\
\hline & 6 p. m- & 19 & June 3 & 8.45 a.m $\mathrm{m}_{\ldots}$ & 27.7 \\
\hline \multirow[t]{2}{*}{ May 18} & ra. m. & 18 & & 7 p. m. & 28.6 \\
\hline & 6 p. m. & 18 & June 4 & 9 a. m. & 29 \\
\hline \multirow[t]{2}{*}{ May $19 \ldots$} & 7 a. m... & 17.4 & & 7 p. m. & 28.8 \\
\hline & 8 p. m. & 16. 2 & June 5 & 9 a. $\mathrm{m}$. & 28.2 \\
\hline \multirow[t]{2}{*}{ May 20} & 7 a. $\mathrm{m}_{-}$ & 16.2 & & 6 p. m. & 27 \\
\hline & 8 p. m. & 15.1 & June 6 . & 6 a. $\mathrm{m}_{\ldots} \ldots$ & 26.5 \\
\hline \multirow[t]{2}{*}{ May $21 \ldots$} & 9 a. $\mathrm{m}_{\ldots}$ & 10 & & $\tau$ p. m. & 28.1 \\
\hline & 8 p. m. & 5 & June $\tau$ & 6 a. $\mathrm{m} \ldots$ & 28.5 \\
\hline May 2.i. & 11 p. m.. & 4 & & 8 p. m & 28.1 \\
\hline \multirow[t]{2}{*}{ May 26} & 7 a. m. & 16.9 & June 8 & 7 a. m. ... & 25.7 \\
\hline & 2 p. m & 13.5 & & 7 p. m... & $2 \pi .1$ \\
\hline
\end{tabular}


Gage height, in feet, of Neosho River at Humboldt, Kans., April 23 to 25 and IIay 6 to $J u l y, 1904$-Continued.

\begin{tabular}{|c|c|c|c|c|c|}
\hline Date. & Time. & Height. & Date. & Time. & Height. \\
\hline & & Feet. & & & Feet. \\
\hline \multirow[t]{2}{*}{ June 9} & 6.30 a. $\mathrm{m}_{\ldots}$ & 26.2 & June 29 & \%.m. & 23.3 \\
\hline & 7.30 p.m. & 25.7 & June 30 & \% a. m & 23.3 \\
\hline \multirow[t]{2}{*}{ June 10} & 7a. m. & 24.8 & & ร p. m. & 22.9 \\
\hline & 6 p. m. & 24.2 & July 1 . & 8 a. $\mathrm{m}_{-}$ & 22.9 \\
\hline \multirow[t]{2}{*}{ June 11. } & 6.30 a.m & 21.7 & & \% p. m. & 22.7 \\
\hline & r p. m. & 15 & July 2. & 8 a. m. & 22.3 \\
\hline \multirow[t]{2}{*}{ June 12. } & 6 a. $\mathrm{m}$ & 12.5 & & \% p. m. & 21.3 \\
\hline & T p. m. & 14 & July 3 & ra. m. & 17 \\
\hline \multirow[t]{2}{*}{ June 13.} & 6 a. m. & 15 & & 7.30 p.m & 10.8 \\
\hline & r p. m. & 16.4 & July 4 & 7.30 a.m & 11.3 \\
\hline \multirow[t]{2}{*}{ June 14} & ra. $\mathrm{m}_{-}$ & 17 & & 6.30 p.m & 12 \\
\hline & \% p. m. & $1 \% .2$ & July 5. & ra. m... & 12.4 \\
\hline \multirow[t]{2}{*}{ June 15} & 6 a. $\mathrm{m}_{-\ldots}$ & 15 & & 6 p. m & 14.3 \\
\hline & 6 p. $\mathrm{m}_{-}$ & 11.3 & July 6 . & 8 a. $\mathbf{m}_{\ldots}$ & 23.9 \\
\hline \multirow[t]{2}{*}{ June 16} & 6 a. $\mathrm{m}_{-}$ & 14 & & 8.30 p.m & 24.5 \\
\hline & r p.m. & 17.5 & July $\tau_{\ldots} \ldots$ & 10 a. $\mathrm{m}$ & 26 \\
\hline \multirow[t]{2}{*}{ June 17} & ra. m. & 18.3 & & $7.30 \mathrm{p} . \mathrm{m}$ & 27.5 \\
\hline & \% p. m. & $1 \% .7$ & July 8 & 8 a. m. & 28.7 \\
\hline \multirow[t]{2}{*}{ June 18} & 6 a. $\mathrm{m}$ & 14.5 & & 7 p. m. & 28.3 \\
\hline & i p. m. & 11.9 & July 9 & 2 a. $\mathrm{m}_{\ldots}$ & 28.7 \\
\hline \multirow[t]{2}{*}{ J une 19} & ra. m. & 11.9 & & $12 \mathrm{~m} \ldots$ & 29 \\
\hline & $8 \mathrm{p} . \mathrm{m} .$. & 13.7 & & 9 p. m... & 30 \\
\hline \multirow[t]{2}{*}{ June 20} & $7.30 \mathrm{a} . \mathrm{m}$ & 14.5 & July $10 \ldots$ & 8 a. $\mathrm{m}_{-}$ & 30.3 \\
\hline & 8 p. m & 15.7 & & $\tau$ p. m. & 30.7 \\
\hline \multirow[t]{2}{*}{ June 21} & 6 a. $\mathrm{m}$ & 16 & July 11 & 8 a.m. & 30 \\
\hline & ip.m. & 15.8 & & 8 p. m. & 29.5 \\
\hline \multirow[t]{2}{*}{ June 22} & 6 a. $\mathrm{m}_{-}$ & 15.4 & July $12 \ldots$ & ra. m. & 28.9 \\
\hline & 8.30 p.m. & 12.6 & & $\tau$ p. m. & 28.5 \\
\hline \multirow[t]{2}{*}{ June 23} & ra. m- & 10.4 & July 13 & r.30 a.m & $2 \% .5$ \\
\hline & 8 p. m & 8 & & 7.30 p.m & 27 \\
\hline \multirow[t]{2}{*}{ June 24} & 7a. m. & 7 & July 14 & $7.30 \mathrm{a} . \mathrm{m}$ & 26.4 \\
\hline & $6 \mathrm{p} . \mathrm{m}$ & 5 & & r p. m & 25.8 \\
\hline \multirow[t]{2}{*}{ June 25} & ra. m. & 10 & July $15 \ldots$ & 8 a. m. & 25.3 \\
\hline & $\gamma \mathrm{p} . \mathrm{m}_{-}$ & 19.8 & & ; p. m. & 24.8 \\
\hline \multirow[t]{2}{*}{ June 26} & 11 a. $\mathrm{m}$ & 22.7 & July 16 & 7 a. $m_{-}$ & 24 \\
\hline & r p. m. & 23.4 & & 8 p. m. & 21.9 \\
\hline \multirow[t]{2}{*}{ June 27} & ra. m. & 24.6 & July 17 & 8 a. $\mathrm{m}_{-}$ & 14 \\
\hline & 7.30 p.m & 27.8 & & r p.m. & 10 \\
\hline \multirow[t]{2}{*}{ June 28} & \% a. $\mathrm{m}_{-}$ & 25 & July 18 & 6 a. $\mathrm{m}$ & 9 \\
\hline & r p. m. & 24.3 & & $\tau$ p. m. & 5 \\
\hline June 29 & 8 a.m. & 23.5 & & & \\
\hline
\end{tabular}




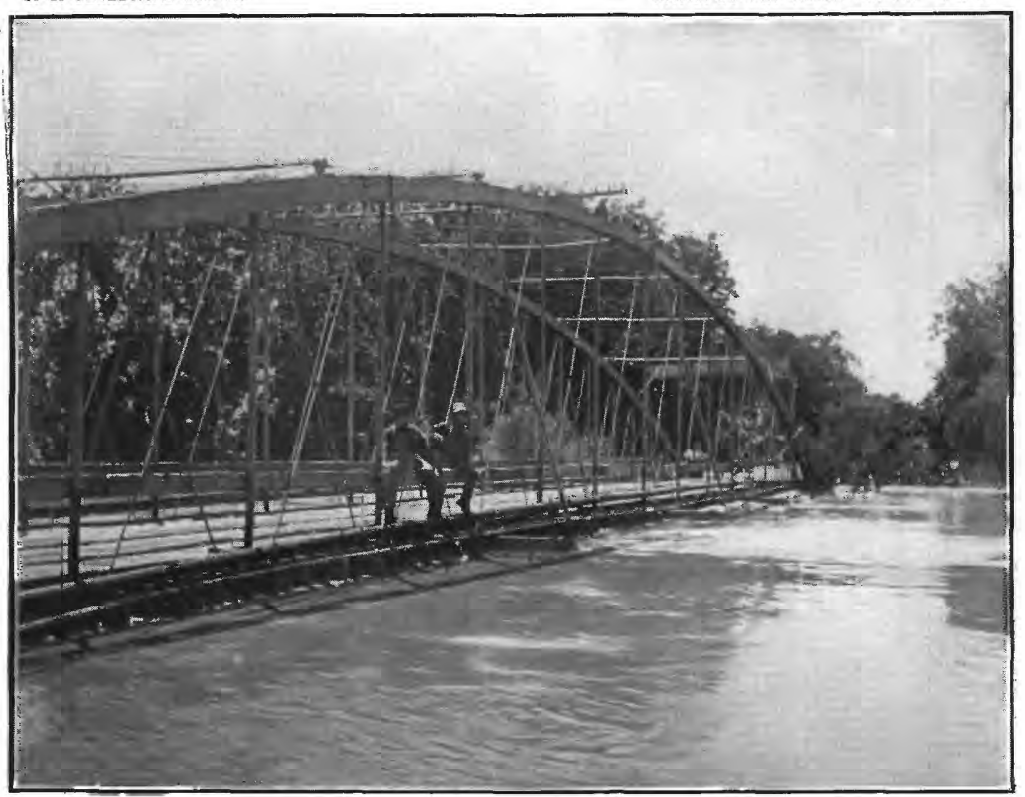

A. FLOOD IN NEOSHO RIVER AT HIGHWAY BRIDGE AT HUMBOLDT, KANS.

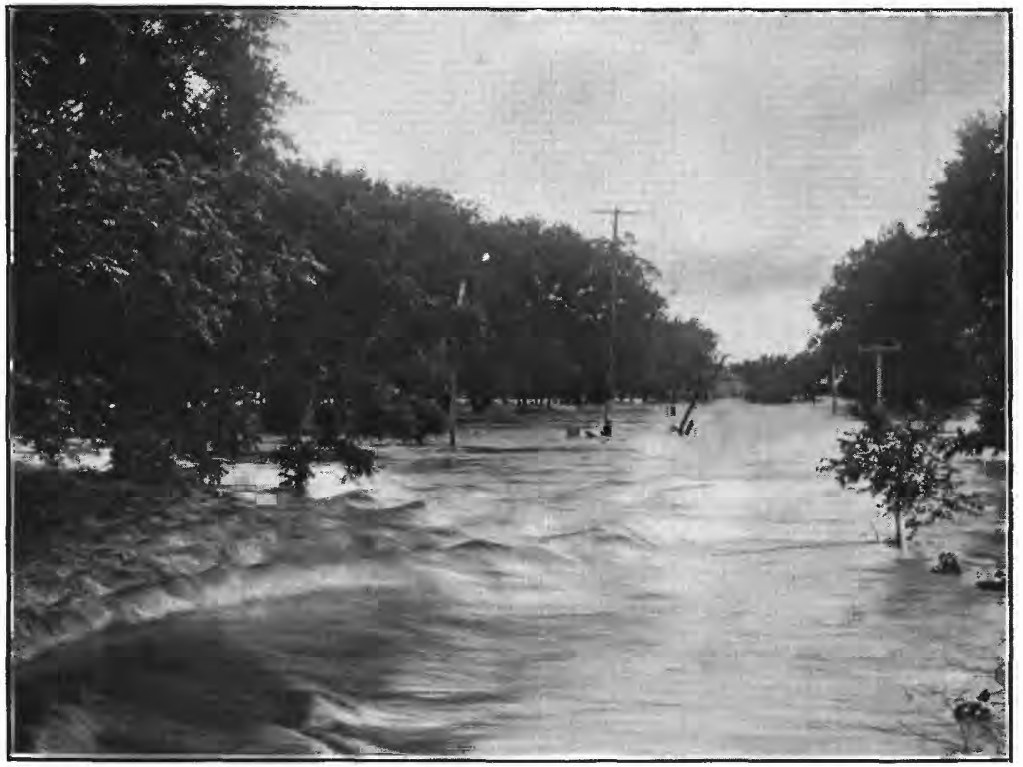

B. OVERFLOW OF RIGHT BANK OF NEOSHO RIVER AT HIGHWAY BRIDGE AT HUMBOLDT, KANS. 
It is seen from these gage records that this river was in flood much of the time from April 24 to July 17. A stage of 27.3 feet above low water was reached April 25 ; a stage of 29 feet was reached June 4 ; a stage of 27.3 feet was reached on June $2 \tau$; and a stage of 30.7 feet, the maximum for the year, was reached on July 10 . The highest known water at this place prior to 1904 was in 1885 . The flood of June 10, 1904, was about 1 foot higher in stage than at that time. The highest water of 1903 was about 3 feet less than the July flood of 1904 .

The left bank of the river at Humboldt is comparatively high, so that the city did not suffer from the flood; the right bank, however, is low and was overflowed for a distance of about 3 miles back from the stream. Pl. VII shows views of the Neosho River during the flood. From it a good idea can be obtained of the extent of the overflow and also of the velocity of the water.

\section{FLOODS NEAR NEOSHO RAPIDS, KANS.}

A flood-gaging station was established at the Santa Fe Railway bridge at Neosho-Rapids in April, 1904, at a point a short distance below the mouth of Cottonwood River. The fluctuations of the surface at this station, measured with a chain gage, are as follows:

Gage height, in feet, of Neosho River at Neosho Rapids, Kans., May 16 to July 18, 1904 .

\begin{tabular}{|c|c|c|c|c|c|}
\hline Date. & $7.20 \mathrm{a} . \mathrm{m}$. & $6 \mathrm{p} . \mathrm{m}$. & Date. & $7.20 \mathrm{a.m}$ & 6 p.m. \\
\hline May $16 \ldots$ & $\begin{array}{c}\text { Feet. } \\
20.6\end{array}$ & $\begin{array}{c}\text { Feet. } \\
21\end{array}$ & June $4 \ldots$ & $\begin{array}{c}\text { Feet. } \\
\text { a } 35.2\end{array}$ & $\begin{array}{l}\text { Feet. } \\
\mathbf{3 4 .} 3\end{array}$ \\
\hline May $1 \%$ & 26.2 & $2 \pi .2$ & June $5 \ldots$ & 33.4 & 33 \\
\hline May 18 & $2 \% .8$ & 24.3 & June 6 & 31 & 29.5 \\
\hline May 19 & 21.9 & 19 & June $\%$ & 28.1 & 27 \\
\hline May 20 & 14.7 & 14 & June $8 \ldots \ldots$ & 26.1 & 24 \\
\hline May 21 & 13.8 & 13.6 & June 9 & 18.7 & 18 \\
\hline May 22 & 13.6 & 13.5 & June 10 & 16. 2 & 22.6 \\
\hline May 23 . & 13.4 & 13.4 & June 11 & 28.3 & 30.4 \\
\hline May 24 . & 13.3 & 13.3 & June $12 \ldots$ & 29.7 & 28.4 \\
\hline May 25 & 12.9 & 12.9 & June $13_{-}$ & 25 & 23.5 \\
\hline May 26 & 14 & 14.9 & June $14 \ldots$ & 18 & 16.5 \\
\hline May 27 . & 21.1 & 21 & June $15 \ldots \ldots$ & 15.5 & 15 \\
\hline May 28 & 19.4 & 19 & June 16 & 17 & 19.1 \\
\hline May 29 & 20 & 30 & June 17 & 20.5 & 21.5 \\
\hline May 30 & 32 & 34.1 & June $18 \ldots \ldots$ & 23 & 23.7 \\
\hline May 31 & 33.6 & 32 & June $19 \ldots$ & 25.2 & 26.5 \\
\hline June 1 . & 31.9 & 30.9 & June 20 & 26.5 & 24.2 \\
\hline June 2 & 28.5 & 28.6 & June $21 \ldots$ & 20.2 & $1 \pi .2$ \\
\hline June 3. & 31.8 & 33.2 & June $22 \ldots$ & 16 & 15.6 \\
\hline
\end{tabular}


Gage height, in feet, of Neosho River at Neosho Rapids, Kans., May 16 to July 18, 1904-Continued.

\begin{tabular}{|c|c|c|c|c|c|}
\hline Daie. & $7.20 \mathrm{a.m}$ & 6 p. m. & Date. & $7.30 \mathrm{a.m}$. & 6 p. m. \\
\hline June 23. & $\begin{array}{c}\text { Feet. } \\
15\end{array}$ & $\begin{array}{l}\text { Feet. } \\
14.5\end{array}$ & July 6 & $\begin{array}{l}\text { Feet. } \\
31.4\end{array}$ & $\begin{array}{c}\text { Feet. } \\
33\end{array}$ \\
\hline June 24 & 14 & 14 & July 7 & 34.4 & a 36.1 \\
\hline June 25 & 22.7 & 25 & July 8 & 35.2 & 35.1 \\
\hline June 26 & 31.1 & 32.2 & July 9 & 34.4 & 33.9 \\
\hline June $2 \%$. & 33.3 & 32.8 & July 10 & 33.8 & 33.5 \\
\hline June 28 & 31.2 & 29.6 & July 11 & 33.2 & 33 \\
\hline June 29 & $2 \pi .1$ & 26.6 & July 12 & 32.8 & 32 \\
\hline June 30 & 25.3 & 24.5 & July 13 . & 30 & 29.4 \\
\hline July 1 & 22.3 & 20.1 & July 14 . & 27.1 & 23 \\
\hline July 2 & 17.1 & 16.6 & July 15 - & 17.5 & 16.1 \\
\hline July 3 & 18.6 & 18.5 & July 16 . & 16.9 & 17 \\
\hline July 4 . . & 19.1 & 20.4 & July $17 \ldots$ & 16.5 & 16 \\
\hline July 5 & 24.2 & 26 & July 18 . & 15.2 & 14.4 \\
\hline
\end{tabular}

a Midnight.

It is seen from these figures that there have been five floods of considerable magnitude at this place from May 17 to July 14, 1904. The first one reached its maximum on May 18, with a gage height of 27.8 feet; the second reached its maximum on May 30, with a gage height of 34.1 feet; the third reached its maximum June 4, with a gage height of 35.2 feet; the fourth reached its maximum June 27 , with a gage height of 33.3 feet, and the fifth reached its maximum July 7 , with a gage height of 36.1 feet. The highest flood of 1903 at this place reached an elevation of about $2 \frac{1}{2}$ feet less than the stage on July $\tau, 1904$.

\section{FLOOD NEAR EMPORIA, KANS.}

Cottonwood River rises in the eastern part of McPherson County and flows in a general eastwardly direction, emptying into the Neosho about 8 miles southeast of Emporia. The distance from source to mouth in a straight line is about 75 miles. The river falls from an elevation of about 1,475 feet to 1,045 feet. The extreme width of the watershed is about 40 miles. The land is hilly, or gently rolling, prairie, pasture, or cultivated land, without many trees, except along the streams.

There is no gage at Emporia on either the Cottonwood or Neosho, but the records relative to high floods are kept at the Emporia pumping station on the Neosho and at J. R. Soden's mill, near Emporia, on the Cottonwood.

The highest water at Soden's mill prior to 1904 was on May 28, 
1903. On June 3, 1904, the water was 28 inches higher at this mill than on May 28, 1903, and on July 5 and 6, 1904, the water was 22 inches higher than on May 28, 1903.

According to the record of Mr. F. A. Bacon, engineer of the Emporia Waterworks Company, the highest water at the pumping station prior to 1904 was on May 29, 1903, at which time the water was 351 inches deep on the floor of the engine room. On May 29, 1904 , the water was $29 \frac{1}{2}$ inches deep on its floor. On June 3, 1904, it again was $29 \frac{1}{2}$ inches deep. On June 26 it was 28 inches deep, and on July 6,1904 , at 12 noon, it was $36 \frac{1}{2}$ inches deep. The water remained from July 5 to 8 in the pump house-that is, for three days the stage of the river remained within 3 feet of the greatest height it ever attained. Nearly all the country between these two rivers in the vicinity of Emporia was flooded and the crops destroyed. The railroads along the river and crossing it were tied up for several days. The Neosho branch of the Missouri, Kansas and Texas Railroad, which extends from Junction City to Parsons, suffered severely, but none of the bridges were washed away.

\section{FLOOD NEAR CHANUTE, KANS.}

About $3 \frac{1}{2}$ miles north of Chanute the Neosho makes a sharp bend to the west side of the valley, and remains on that side for about 7 miles. The major part of the water of the 1904 flood, instead of following this large bend, cut across it at a velocity sufficiently large to badly damage the levees in its path, destroy the crops, and cause considerable loss to the oil interests. Several of the oil tanks were moved from their foundation, some of them were overturned, and a few were swept away. The pumping machinery was injured to some extent by the dirty water.

The flood of July passed at least 1 foot in depth over all the levees. Nearly all of them were damaged to some extent and in places they. were completely destroyed. The greatest damage was usually around culverts that passed the water through the levee. The water was so high here that a boat was rowed through the doors of a freight car standing on the Missouri, Kansas and Texas Railroad near the depot. The flood marks at the pumping station indicate that the July, 1904, Hood was about 8 inches higher at Chanute than the flood of 1885 and was about 2 feet higher than the highest water of 1903 .

FLOOD NEAR FOR'T GIBSON, IND. T.

A gaging station was established on Neosho River at the Missouri Pacific Railway bridge near Fort Gibson, Ind. T., in September, 1903, and the following gage heights were taken during June and July, 1904, during the floods on the upper river. 
Gage height, in feet, on Neosho River near Fort Gibson, Ind. T., 190.t.

\begin{tabular}{|c|c|c|c|c|c|c|c|}
\hline Date. & May. & June. & July. & Date. & May. & June. & July. \\
\hline 1. & & 14.00 & 18.80 & 17 & & $1 \% .00$ & 25.00 \\
\hline 2. & & 18.60 & 18.20 & 18. & & 16.50 & 24.60 \\
\hline 3. & & 20.00 & 20.00 & 19 & & $1 \% .00$ & 23.00 \\
\hline $4 \ldots$ & & 26.50 & 21.00 & 20 & & 17.50 & 21.00 \\
\hline 5. & & 33.00 & 22.60 & 21 & & 18.20 & 19. 20 \\
\hline 6. & & 32.60 & 23.00 & 22 & & 18.00 & 19.00 \\
\hline$i$. & & 29.00 & 26.00 & $23 \ldots$ & & $1 \% .10$ & 18. 20 \\
\hline 8. & & 27.00 & $2 \% .00$ & $24 \ldots$ & & 16. 40 & 16.00 \\
\hline 9. & & $2 \pi .00$ & 28.00 & 25. & & 15.00 & 15.80 \\
\hline 10. & & 25.50 & 29.00 & 26 . & & 15.40 & 15. 20 \\
\hline 11. & & 25.50 & 32.40 & $2 \pi_{-}$ & & 16.00 & 14.80 \\
\hline 12. & & 24.00 & 32.20 & 28 & & 18.80 & 14.40 \\
\hline 13. & & 24.00 & 32.00 & 29 & 11.80 & 19.00 & 13.80 \\
\hline 14. & & 22.20 & 31.60 & $30 \ldots$ & 12.00 & 19.80 & 14.00 \\
\hline 5 & & 20.00 & 30.80 & $31 \ldots$ & 13.00 & & \\
\hline & & 19.50 & 30.00 & & & & \\
\hline
\end{tabular}

It is seen from this table that the river was high during June and July. A maximum stage of 33 feet was reached on June 5 and again a maximum stage of 32.4 feet on July 11, this last being about 23 feet above low water.

\section{LEVEES OF NEOSHO COUNTY.}

Levee building was begun in Neosho County, Kans., in 1892, and has gradually grown until at the present time there are 19 levee districts along Neosho River, varying in size from 220 acres to 2,000 acres, depending upon the topography of the country. A stream or high land that does not need the levee serves as a boundary. The height of the levees is referred to the height of the greatest flood of 1885 , the crown of each levee being supposed to be from $1 \frac{1}{2}$ to 2 feet above the flood height of that year. The crown width varies from 3 to 6 feet, the latter being the width of those recently completed.

The side slopes vary from $1 \frac{1}{2}$ to 1 to 2 to 1 , the greatest height being about 10 feet. The material for the levees is obtained near the place of construction, and is usually very good for the purpose, as it contains a considerable amount of clay. The cost of construction ranges from 7 to 18 cents per cubic yard, and the cost per acre reclaimed from $\$ 8$ to $\$ 12$. The Nixon levee, for instance, built in 1903, protects 626.1 acres and cost $\$ 5,681.90$. The cost per vear for repairs varies widely, depending on exposure to action of river, ranging from 
nothing to $\$ 1.25$ per acre, but generally amounting to from 25 to 50 cents an acre. Some levees built nine years ago have required no repairs. These levees have protected the land against ordinary flood, and as most of the land thus protected is almost valueless without flood protection they have well repaid the cost of their construction. The belief is very general that several of them are too near the river, and thus restrict the stream waterways, and that they are not sufficiently high and thick. The levee districts are formed and the levees built and maintained by a board of county commissioners.

\section{NECESSARY WIDTH OF CHANNEL.}

For 230 miles from the month of the river its average slope is less than 2 feet per mile, and there are long stretches where the slope is only 1.7 feet per mile. The stream is also very crooked, so that the effective slope is smaller than that of other similar streams. The frequent overflows of the river are due to the sluggish flow which results from this small slope of bed. The only means of increasing the slope is by shortening the stream-that is, removing some of the bends. As this remedy is not practicable, the only remaining palliative is to make the waterway area large and use levees. As the volume of flood flow, the average slope of the stream, and the depth of water are known, it is possible to compute the approximate size of a trapezoidal channel that will safely carry the flood flow without overflow of levees of a reasonable height.

The flood discharge of the Neosho at Iola in 1904 was about 75,000 cubic feet per/second, and the depth of water was about 23 feet above low water. The average surface slope at this place is approsimately 2.3 feet per mile. The effective slope is somewhat less, and we will assume it to be 2.2 feet per mile. The coefficient of roughness of bed $(n)$ in Kutter's formula is assumed to be 0.030 . From these data we find that a trapezoidal channel having a bottom width of 420 feet, side slopes 1.5 to 1 or top width of 486 feet, depth 22 feet, will carry a volume of 75,000 cubic feet per second.

That is, if the channel of the Neosho in the vicinity of Iola were approximately trapezoidal in shape with a top width of 486 feet, bottom width 420 feet, and banks or levees on each side, so that the overflow could not take place for a height of water of 22 feet above low water, the flood of 1904 would have passed down the stream without overflow. The width between the abutments of the bridge at Iola is only 190 feet, so that there was a very large overflow on each side of the bridge.

In the vicinity of Chanute and farther down the river, where the slope of the stream is consideraly less than at Iola, the top width of the channel will need to be from 650 to 700 feet between the levees. 
The damage done along this stream consisted mainly in the loss of crops. The overflow water had very little velocity, but spread out over a large area, ruining a large acreage of crops, but not destroying the land, as was the case along Kansas River during the 1903 flood. The cities and towns along the river are, as a rule, situated a considerable, distance back from the river and out of the reach of floods. Very few bridges were injured by the flood. The railroads suffered quite heavily, especially the Missouri, Kansas and Texas, which parallels the river. For several days trains could not run over this road, and the loss in traffic and injury to roadbed was large. The oil industries along the river, especially in the vicinity of Chanute, suffered heavily in loss of time and damage to machinery. The levees along the river in Neosho County, described on page 92, suffered to a large extent.

\section{PREVENTION OF FUTURE DAMAGE.}

Floods occur annually on the Neosho that cause overflow of much valuable land, destroying crops and making agriculture very uncertain. This overflow is due to the small slope of the river, small area of waterway, and to the numerous bends in the stream.

Levees have been used to prevent overflow in some parts of the river valley and serve their purpose well in the case of ordinary floods. By building levees sufficiently far apart to give a larger waterway to the river, building them a few feet higher, and protecting them at exposed places they will protect the land against all floods.

\section{VERDIGRIS RIVER FLOODS.}

Floods are common on Verdigris River. Rarely a year passes without a flood that causes overflow of some of the bottom lands along the river. There were five floods on this river from April 26 to July 10, 1904, that reached a stage of more than 27 feet above low water at Independence, and two of these reached a stage of more than $\$ 1$ feet above low water.

\section{STREAMS AND DRAINAGE BASIN.}

Verdigris River rises in the southeastern corner of Chase County, Kans., flows in a southerly direction through Kansas and part of Indian Territory, and empties into Arkansas River. Its length, as found by measurement on the best available maps, is 290 miles. It 
falls from an elevation of 1,400 feet at its source to 700 feet at a point about 11 miles north of the Kansas and Indian Territory line, a distance of 141 miles. From this point to the mouth, a distance of 148 miles, it falls about 100 feet. Throughout its length the river flows in a well-defined channel with banks from 10 to 40 feet in height. The width at ordinary stage of water at the State line is 140 feet and at the mouth 250 feet. It is essentially a surface run-off stream; its water is muddv, its flood flow large, summer flow small, and surface fluctuations quite large and rapid. Although it flows in a comparatively deep and well-defined channel, its banks are frequently subject to overflow during floods, on account of the sluggish flow due to small fall and crooked channel. The bed and banks are composed of firm material, that changes very little from year to year.

The principal tributaries of Verdigris River. are Fall River, Elk River, Caney River, and Bird Creek. These all enter the river from the west and take a southeasterly direction. The first three rise in the Flint Hills of Butler County, Kans., and the last in Indian Territory.

Caney River, the largest of the four, drains an area of 2,440 square miles, has a length of 140 miles, and falls from an elevation of 1,500 feet at its source to 750 feet near the State line, a distance of 48 miles.

Fall River is 96 miles long and has a fall of from 1,500 to 750 feet in a distance of 43 miles. Its drainage area is 875 square miles. Its water is less muddy and its flow more steady than that of Verdigris River. The width near the mouth at ordinary low water is 75 feet.

Elk River drains an area of 687 square miles. Its length is 70 miles and its width near the mouth at ordinary low water 75 feet. It falls from an elevation of 1,500 feet to 750 feet in a distance of 43 miles. Its discharge is smaller and its flow less steady than Fall River, resembling the main stream in this respect.

Bird Creek has a length of 85 miles and drains an area of 1,340 square miles.

The watershed of Verdigris River has an area of 8,610 square miles. Its total length is 180 miles and its greatest width 72 miles. The Flint Hills, in the northern part of its boundary, have an elevation of about 1,600 feet. The northern boundary varies in height from 1,200 to 1,400 feet. The eastern boundary falls from about 1,400 to 650 feet and the western boundary from 1,600 to 650 feet, decreasing from the north toward the south. The upper part is comparatively rough, the general fall toward the river being about 25 feet to the mile. This portion of the watershed is used for grazing purposes. The rest of the basin contains some of the best farming land in the Mississippi River Valley. In some parts the general surface is. 
broken by mounds having an elevation of from 100 to 250 feet above the general level; such is Table Mound, 6 miles northwest of Independence, and the mounds near Fredonia and Cherryvale, Kans., and near Sageeyah, Ind. T.

The following table gives the distance in miles between 50-foot contours along Verdigris, Fall, and Elk rivers:

Distance, in miles, between 50-fout contours along Terdigris, Fall, and Elk rivers.

\begin{tabular}{|c|c|c|c|}
\hline \multirow{2}{*}{ Elevation in feet. } & \multicolumn{3}{|c|}{ Distance between contours. } \\
\hline & $\begin{array}{c}\text { Verdigris } \\
\text { River. }\end{array}$ & $\begin{array}{c}\text { Fall } \\
\text { River. }\end{array}$ & $\underset{\text { River. }}{\text { Elk }}$ \\
\hline 1,300 to 1,250 & 3 & 2 & 1 \\
\hline 1,250 to 1,200 & $\mathcal{2}$ & 2 & 2 \\
\hline 1,200 to 1,150 & $r$ & 3 & 2 \\
\hline 1,150 t, 1,100 & 4 & 3 & 4 \\
\hline 1,100 to $1,0,50$ & 3 & $\ddot{3}$ & 3 \\
\hline 1,050 to 1,000 & $\gamma$ & 6 & 3 \\
\hline 1,000 to 950 & 6 & 13 & 4 \\
\hline 950 to & 12 & 22 & 4 \\
\hline 900 to & 30 & 19 & 6 \\
\hline 850 to & 32 & 16 & 16 \\
\hline 800 to & 8 & - - - & 12 \\
\hline 750 to 700 & 26 & & $\cdots$ \\
\hline 700 to & 148 & - & $\cdots$ \\
\hline
\end{tabular}

DISCHARGE AND RUN-OFF.

A gaging station was established on the Verdigris August 2, 1895, at McTaggart's mill, 7 miles east of Independence and 3 miles southwest of Liberty. The gage consists of two parts, one a vertical timber spiked to the flume of the mill and reading from 0 up to 8 feet, the other of foot and half-foot marks painted on the wheelhouse of the mill. Discharge measurements have been made from the highway bridge a few hundred feet below the dam.

The chanrel at this place is straight for several hundred feet above and below the bridge. The flow has a moderate velocity at low as well as high stages. The bed is mainly rock and not subject to change. The banks, although of considerable height, are subject to overflow during very high floods.

The following table shows the mean monthly and annual discharge and run-off obtained at this station from 1896 to 1903 : 
Estimated monthly discharge of Verdigris River at Liberty, Kans., 1895-1903.

[Drainage area, 3,067 square miles.]

\begin{tabular}{|c|c|c|c|c|c|c|}
\hline \multirow[b]{2}{*}{ Month. } & \multicolumn{3}{|c|}{ Discharge in second-feet. } & \multirow[b]{2}{*}{$\begin{array}{l}\text { Total in } \\
\text { acre-feet. }\end{array}$} & \multicolumn{2}{|c|}{ Run-off. } \\
\hline & $\begin{array}{l}\text { Maxi- } \\
\text { mum. }\end{array}$ & $\begin{array}{l}\text { Mini- } \\
\text { mum. }\end{array}$ & Mean. & & $\begin{array}{l}\text { Depth in } \\
\text { inches. }\end{array}$ & $\begin{array}{l}\text { Second-feet } \\
\text { per square } \\
\text { mile. }\end{array}$ \\
\hline 1895. & & & & & & \\
\hline August ... & 7,121 & 20 & 783 & 48,144 & 0.294 & 0.255 \\
\hline September & 37,000 & 87 & 5,985 & 356,132 & 2.179 & 1.953 \\
\hline October .... & 155 & 39 & 69 & 4,243 & .025 & .022 \\
\hline November & 171 & 39 & 82 & 4,879 & .030 & .027 \\
\hline December . . . . & 28,000 & 68 & 4,226 & 259,847 & 1.589 & 1.378 \\
\hline $\begin{array}{c}1896 . \\
\text { January }\end{array}$ & 1,136 & 450 & 661 & 40,643 & .249 & .216 \\
\hline February & 790 & 256 & 426 & 24,503 & .145 & .139 \\
\hline March & 351 & 171 & 242 & 14,880 & .091 & .079 \\
\hline April. - & 3,882 & 171 & 677 & 40,285 & .246 & .221 \\
\hline May _... & 19,900 & 171 & 4,181 & 257,080 & 1.572 & 1.363 \\
\hline June ....... & 16,620 & 303 & 2,200 & 130,909 & .800 & .717 \\
\hline July _....... & 10,770 & 138 & 1,699 & 104,467 & .639 & .554 \\
\hline August & 210 & 14 & 46 & 2,828 & .017 & .015 \\
\hline September - & 424 & 5 & 71 & 4,225 & .026 & .023 \\
\hline October ...... & 8,720 & 9 & 600 & 36,893 & .226 & .196 \\
\hline November & 9,130 & 110 & 1,017 & 60,516 & .369 & .331 \\
\hline December . & 1,010 & 171 & 448 & 27,547 & .168 & .146 \\
\hline The year. & 19,900 & 5 & 1,022 & 744,776 & 4.548 & .333 \\
\hline 1897. & & & & & & \\
\hline January... . & 1,616 & 351 & 887 & 54,540 & .333 & .289 \\
\hline February & 5,276 & 450 & 1,591 & 88,360 & .532 & .518 \\
\hline March $\ldots$ & 14,470 & 553 & 2,201 & 135,333 & .838 & .718 \\
\hline April . . . . & 26,100 & 450 & 2.829 & 168,338 & 1.030 & .923 \\
\hline May ..... & 8,105 & 256 & 1,260 & 77,474 & .474 & .411 \\
\hline June .... & 4,005 & 52 & 505 & 30,050 & .184 & .165 \\
\hline July ..... & 4,989 & 39 & 408 . & 25,088 & .153 & .133 \\
\hline August ...... & 39 & 20 & 28 & 1,722 & .011 & .009 \\
\hline September ... & 20 & 20 & 20 & 1,190 & .008 & .007 \\
\hline October & 20 & 5 & 8 & 492 & .003 & .003 \\
\hline November.... & 5 & 2 & 2 & 119 & .001 & .001 \\
\hline December . . . & 39 & 2 & 12 & 738 & .004 & .004 \\
\hline The year & 26,100 & 2 & 813 & 583,444 & 3.571 & .267 \\
\hline
\end{tabular}

IRR $147-05 \mathrm{M}-7$ 
Estimated monthly discharge of Terdigris River, etc.-Continued.

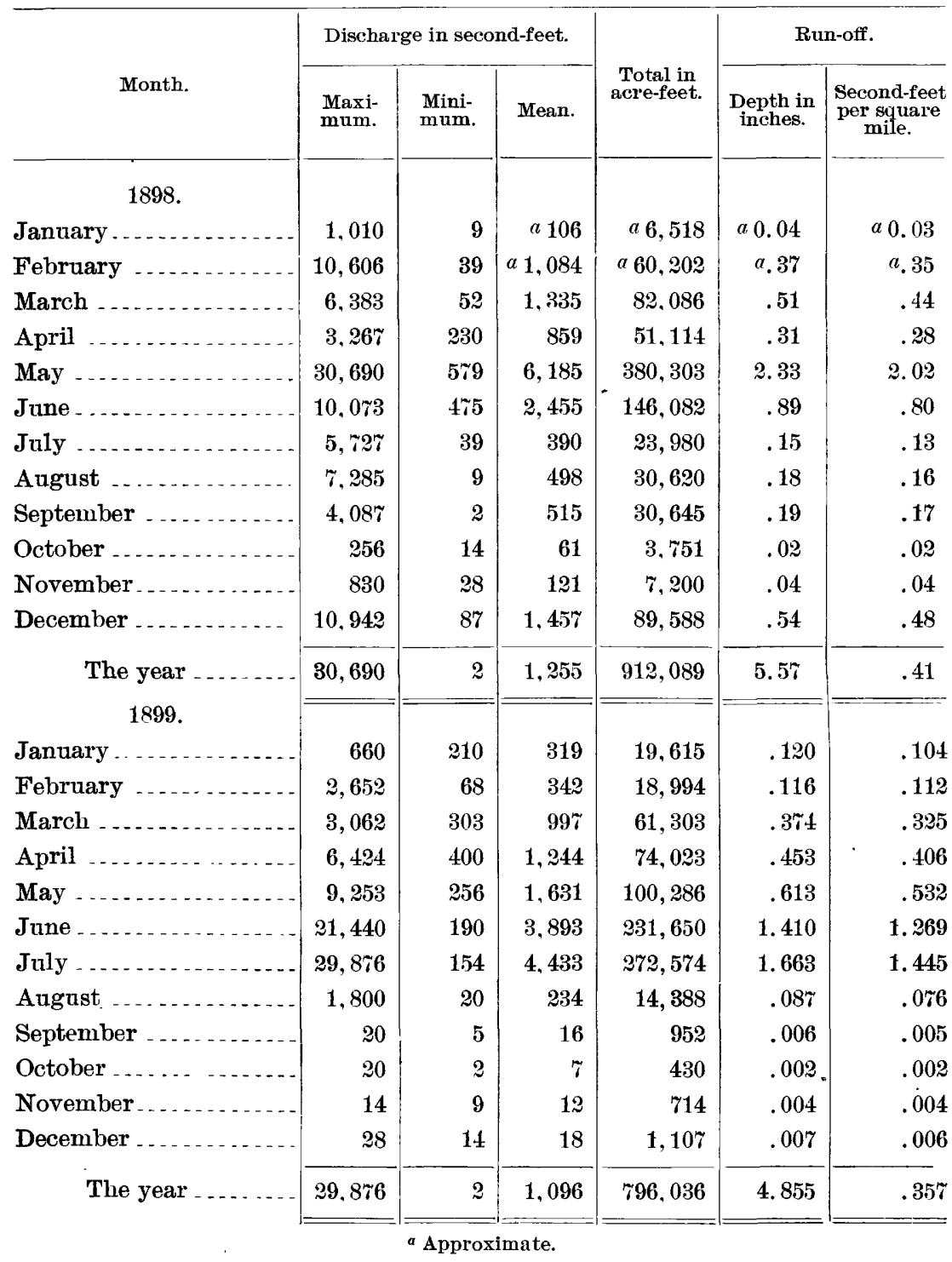


Estimated monthly discharge of Verdigris River, etc.-Continued.

\begin{tabular}{|c|c|c|c|c|c|c|}
\hline \multirow[b]{2}{*}{ Month. } & \multicolumn{3}{|c|}{ Discharge in second-feet. } & \multirow[b]{2}{*}{$\begin{array}{l}\text { Total in } \\
\text { acre-feet: }\end{array}$} & \multicolumn{2}{|c|}{ Run-off. } \\
\hline & $\begin{array}{l}\text { Maxi- } \\
\text { mum. }\end{array}$ & $\begin{array}{l}\text { Mini- } \\
\text { mum. }\end{array}$ & Mean. & & $\begin{array}{c}\text { Depth in } \\
\text { inches. }\end{array}$ & $\begin{array}{l}\text { Second-feet } \\
\text { per square } \\
\text { mile. }\end{array}$ \\
\hline 1900. & & & & & & \\
\hline January _ . . - & 90 & 55 & 65 & 3,997 & .020 & .020 \\
\hline February & 240 & 40 & 82 & 4,554 & .030 & .030 \\
\hline March & 10,200 & 170 & 1,323 & 81,348 & .500 & .430 \\
\hline April ... & 10,750 & 140 & 1,236 & 73,547 & .450 & .400 \\
\hline May ....... & 16,500 & 280 & 2,455 & 150,952 & .920 & .800 \\
\hline June . - & 5,400 & 110 & 593 & 35,286 & .210 & .190 \\
\hline July _.. & 23,610 & 222 & 1,824 & 112,153 & .680 & .590 \\
\hline August .... & 155 & 7 & 58 & 3,259 & .020 & .020 \\
\hline September & 36,950 & 10 & 3,714 & 220,998 & 1.350 & 1. 210 \\
\hline October & $35,0 \% 5$ & 280 & 3,236 & 198,974 & 1.220 & 1.060 \\
\hline November. & 25,430 & 860 & 3,766 & 224,093 & 1.370 & 1.230 \\
\hline December & 860 & 368 & 581 & 32,650 & .200 & .170 \\
\hline The year & 36,950 & 7 & 1,573 & $1,141,811$ & 6.970 & .510 \\
\hline 1901. & & & & & & \\
\hline January . . . . . & 860 & 280 & 465 & 28,592 & .174 & .151 \\
\hline February & 2,200 & 368 & 920 & 51,094 & .312 & .300 \\
\hline March - & 7,458 & 368 & 1,006 & 61,857 & .379 & .328 \\
\hline April ... & 16,260 & 760 & 3,272 & 194,697 & 1.195 & $1.06 \%$ \\
\hline May . . . & 2,550 & 90 & 554 & 34,064 & .209 & .181 \\
\hline June . - & 810 & 40 & 122 & 7,259 & .045 & .040 \\
\hline July - . & 90 & 3 & 13 & 799 & .005 & .004 \\
\hline August & 205 & 2 & 30 & 1,845 & .012 & .010 \\
\hline September & 2,200 & 2 & 153 & 9,104 & .056 & .050 \\
\hline October $\ldots$ & 90 & 40 & 55 & 3,382 & .021 & .018 \\
\hline November & 40 & 27 & 37 & 2,202 & .013 & .012 \\
\hline December .... & 55 & 40 & 51 & 3,136 & .020 & .017 \\
\hline The year & 16,260 & 2 & 556 & 398,031 & 2.441 & .182 \\
\hline
\end{tabular}


Estimated monthly discharge of Terdigris River, etc.-Continued.

\begin{tabular}{|c|c|c|c|c|c|c|}
\hline \multirow[b]{2}{*}{ Month. } & \multicolumn{3}{|c|}{ Discharge in second-feet. } & \multirow{2}{*}{$\begin{array}{l}\text { Total in } \\
\text { acre-feet. }\end{array}$} & \multicolumn{2}{|c|}{ Run-off. } \\
\hline & $\begin{array}{l}\text { Maxi- } \\
\text { mum. }\end{array}$ & $\begin{array}{l}\text { Mini- } \\
\text { mum. }\end{array}$ & Mean. & & $\begin{array}{l}\text { Depth in } \\
\text { inches. }\end{array}$ & $\begin{array}{l}\text { Second-feet } \\
\text { per' square } \\
\text { mile. }\end{array}$ \\
\hline 1902. & & & & & & \\
\hline January ..... & 55 & 40 & 45 & $\overline{2}, 767$ & 0.01 & 0.01 \\
\hline February & 1, 780 & 40 & 204 & 11,330 & .07 & .07 \\
\hline March & 785 & 140 & $35 \%$ & 21,951 & .14 & .12 \\
\hline April ...... & 810 & 187 & 268 & 15,947 & .10 & .09 \\
\hline May ........ & 26,438 & 205 & 5,395 & 331,718 & 2.03 & 1. 76 \\
\hline June ..... . & 33,018 & 960 & $\tau, 893$ & 469,666 & 2.87 & 2.57 \\
\hline July . . . . . . & 4,525 & 320 & 1,050 & 64,562 & .39 & .34 \\
\hline August ..... & 6,577 & 100 & 1,051 & 64,623 & .39 & .34 \\
\hline September & 15,650 & 368 & 2,935 & 174,645 & 1.07 & .96 \\
\hline October. & 11,080 & 464 & 1,706 & 104,898 & .65 & .56 \\
\hline November & 8,470 & 464 & 1,598 & 95,088 & .58 & .52 \\
\hline December & 6,433 & 685 & 1,852 & 113,875 & .69 & .60 \\
\hline The year & 33,018 & 40 & 2,030 & $1,471,070$ & 8.99 & .66 \\
\hline 1905. & & & & & & \\
\hline January . ... & 1,060 & 610 & $r 4 \tau$ & 45,931 & .28 & .24 \\
\hline February ... & 21,020 & 392 & 2,348 & 130,401 & .79 & .76 \\
\hline March ....... & 17,800 & 1,164 & 4,112 & 252.837 & 1.54 & 1.34 \\
\hline April $\ldots . .$. & 19,900 & 910 & 3,031 & 180,357 & 1.10 & .99 \\
\hline May ...... & 41,450 & 910 & 10,865 & 668,063 & 4.08 & 3.54 \\
\hline June _ : . . & 26,480 & 560 & 3,981 & 236,886 & 1.45 & 1.30 \\
\hline July _.. & 7,458 & 464 & 1,551 & 95,367 & .59 & .51 \\
\hline August & 4,000 & 560 & 1,514 & 93,092 & .56 & .49 \\
\hline September & 8,810 & 280 & 1,306 & 77,712 & .48 & .43 \\
\hline October ..... & 3,407 & 464 & 1,100 & $6 \tau, 636$ & .42 & .36 \\
\hline November & 11,150 & 660 & 2,367 & 140,846 & .87 & .77 \\
\hline December & 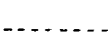 & $-2-$ & & $\ldots$ & .69 & $\ldots$ \\
\hline The yea & & & & & 1.285 & \\
\hline
\end{tabular}

NoTE.-Gage heights and discharge measurements for 1899 are given in Water-Supply and Irrigation Paper No. 37, page 266 ; rating table in Paper No. 39, page 450.

Gage heights and discharge measure?nents for 1900 are given in Water-Supply Paper No. 50, page 331 ; rating table in Paper No. 52, page 518.

Gage heights and discharge measurements for 1901 are given in Water-Supply Paper No. 66 , page 57 ; rating table on page 172 of same paper. 
It is seen that the minimum flow at this place is sometimes only 2 second-feet for sixty or more days at a time. The maximum daily rate of discharge during this period was 41,450 second-feet, on May 23, 1903.

The following table gives the maximum and minimum rate of discharge and run-off at this station:

Maximum and minimum discharge of Verdigris River at Liberty, Kans.

[Drainage area, 3,067 square miles.]

\begin{tabular}{|c|c|c|c|c|c|c|c|c|}
\hline \multirow[b]{2}{*}{ Year. } & \multirow[b]{2}{*}{ Date. } & \multirow{2}{*}{$\begin{array}{c}\text { Gage } \\
\text { height in } \\
\text { feet. }\end{array}$} & \multicolumn{2}{|c|}{$\begin{array}{c}\text { Maximum dis- } \\
\text { charge in second- } \\
\text { feet. }\end{array}$} & \multirow[b]{2}{*}{ Date. } & \multirow{2}{*}{$\begin{array}{l}\text { Gage } \\
\text { height } \\
\text { in feet. }\end{array}$} & \multicolumn{2}{|c|}{$\begin{array}{l}\text { Minimum dis- } \\
\text { charge in } \\
\text { second-feet. }\end{array}$} \\
\hline & & & $\begin{array}{c}\text { From } \\
\text { total } \\
\text { drainage } \\
\text { area. }\end{array}$ & $\begin{array}{c}\text { Per } \\
\text { square } \\
\text { mile. }\end{array}$ & & & $\begin{array}{l}\text { From } \\
\text { total } \\
\text { drain- } \\
\text { age } \\
\text { area. }\end{array}$ & $\begin{array}{l}\text { Per } \\
\text { square } \\
\text { mile. }\end{array}$ \\
\hline 1895 & Sept. 11 & $a 35.50$ & 837,000 & 12.1 & October & 2.20 & 155 & 0.051 \\
\hline 1896 & May 24 & 23.75 & 19,900 & 6.49 & September & 1. $\% 0$ & 5 & .0016 \\
\hline 1897 & Apr. 30 & $c 28.00$ & 26,100 & 8.51 & $\begin{array}{l}\text { November and } \\
\text { Decemb }=r .\end{array}$ & 1.60 & 2 & .00065 \\
\hline 1898 & May $\cdot 4$ & $d 31.00$ & 30,690 & 10.0 & September ... & 1.60 & 2 & .00065 \\
\hline 1899 & July 9 & 30.45 & 29,876 & 9.74 & October & 1.60 & 2 & .00065 \\
\hline 1900 & Sept. 30 & 36.00 & $b 36,950$ & 12.0 & August $\ldots . .$. & 1.55 & 7 & .0023 \\
\hline 1901 & Apr. 13 & 20.40 & 16,260 & 5. 30 & $\underset{\text { September. }}{\text { August and }}$ & 1.20 & 2 & .00065 \\
\hline 1902 & June $\gamma$ & 33.37 & 33,018 & 10.8 & $\begin{array}{c}\text { January and } \\
\text { February. }\end{array}$ & 1.90 & 40 & .013 \\
\hline 1903 & May 23 & 39.00 & 641,450 & 13.5 & September ... & 2.80 & 280 & .091 \\
\hline 1904 & July 8 & 41.00 & 50,400 & 16.43 & & & & \\
\hline
\end{tabular}

a Absolute maximum, 36.40.

${ }^{b}$ Probably too small on account of overflow of banks.

c Absolute maximum, 28.20 .

d Absolute maximum, 31.50.

\section{FLOODS NEAR INDEPENDENCE.}

A flood-gaging station was established on Verdigris River at the highway bridge at Independence in April, 1904. The fluctuations of the surface measured with this gage are given on page 102 . 
Gage height of Verdigris River at Independence, Kans., April to July, 1904.

\begin{tabular}{|c|c|c|c|c|c|}
\hline Date. & Time. & Height. $a$ & Date. & Time. & Height. $a$ \\
\hline & & Feet. & & & Feet. \\
\hline April 24 . & 6.15 p.m. & 19 & June 18 & 5.30 a.m. & 32.5 \\
\hline \multirow[t]{2}{*}{ April 25 . } & 6.12 a.m. & 25.4 & & 7.30 p.m. & 36.6 \\
\hline & 10.50 p.m & 28.1 & June 19 & 5.30 a.m & 37.4 \\
\hline \multirow[t]{2}{*}{ April 26... } & 6 a. $\mathrm{m}$. & 30.1 & & $6.30 \mathrm{p} . \mathrm{m}$ & 35.7 \\
\hline & 5 p. m & 31.5 & June 20 & 6 a. $\mathrm{m}$ & 33.5 \\
\hline \multirow[t]{2}{*}{ May 7.} & 6 a. $\mathrm{m} \ldots$ & 15 & & 6 p. m & 29.1 \\
\hline & 1 p. m. & 16.1 & June 21 & 6 a. $\mathrm{m}_{-}$ & 22.6 \\
\hline \multirow[t]{2}{*}{ June 2 .. } & 6 a. m. & 13 & & 6 p. m. & 16.6 \\
\hline & 6 p. m $\ldots$ & 16.8 & June 22 & 6 a. $\mathrm{m}$ & 14.4 \\
\hline \multirow[t]{2}{*}{ June 3} & $6.35 \mathrm{a} . \mathrm{m}_{-}$ & 29.1 & June 26 & 9 a. m. & 18.2 \\
\hline & 5 p. m & 35.8 & June 27 & 7 a. m. & 23.4 \\
\hline \multirow[t]{11}{*}{ June 4} & $6.30 \mathrm{a} . \mathrm{m}_{\ldots}$ & 36.6 & & 7 p. m. & 25.5 \\
\hline & 8 a. m.... & 37 & June 28 & 5 a. $\mathrm{m}_{-}$ & 26.9 \\
\hline & 9.45 a.m $\mathrm{m}$ & 37.4 & & $7 \mathrm{p.m}$ & 25.1 \\
\hline & $11.12 \mathrm{a.m}$ & 37.8 & June 29 & 6 a. $\mathrm{m}$ & 23 \\
\hline & $12 \mathrm{~m} \ldots$ & 38.0 & & 7 p. m & 19.4 \\
\hline & 1 p. m. & 38.3 & June 30 & 6 a. $\mathrm{m}$ & 15.8 \\
\hline & 3 p. m. & 38.7 & July 1 .. & 5.30 a.m & 17.4 \\
\hline & 4 p. m & 39 & & $6.30 \mathrm{p} . \mathrm{m}$ & 21 \\
\hline & 5.37 p.m & 39.3 & July 2. & 5 a. $\mathrm{m}$ & 24.6 \\
\hline & $7.35 \mathrm{p} . \mathrm{m}_{-}$ & 39.7 & July 4 & 5 a. m. & 31.9 \\
\hline & 11 p. m.... & 40.1 & 1 & 6 p. m & 26.5 \\
\hline \multirow[t]{5}{*}{ June 5} & 6 a. $\mathrm{m}_{-.}$ & 40.7 & July 6 . - & 7.30 a.m & 29.1 \\
\hline & 9 a. $\mathrm{m}_{\ldots}$ & 41.5 & & 1 p. m. & 33.9 \\
\hline & 3.30 p.m. & 40.8 & July 7 & 7 a. m. & 36.2 \\
\hline & 5.30 p.m $\ldots$ & 40.9 & & 8 p. m. & 39.2 \\
\hline & 7.25 p.m. & 41.5 & July 8 & 7.30 a.m & 41.6 \\
\hline \multirow[t]{2}{*}{ June 12} & 5.30 a.m & 30.9 & & 6 p. m.... & 43.2 \\
\hline & 5 p. m & 31.2 & July 9 & 5 a. $\mathrm{m}_{-}$ & 42.8 \\
\hline \multirow[t]{2}{*}{ June 13} & 6 a. $\mathrm{m}_{-}$ & 30.7 & July $10_{\ldots}$ & 5 a. $\mathrm{m}$ & 39.8 \\
\hline & $6 \mathrm{p} \cdot \mathrm{m}$ & 29.8 & & 6 p. m & 38 \\
\hline \multirow[t]{2}{*}{ June 14} & 5.30 a.m & 23.3 & July 11 & 6 a. $\mathrm{m}$ & 36.1 \\
\hline & 7 p. m. & 11.5 & & 6 p. m & 34.1 \\
\hline \multirow[t]{2}{*}{ June 15 . } & 5.30 a.m & 12 & July 12 & 6 a. $\mathrm{m}$ & 31.4 \\
\hline & 7.30 p.m- & 12 & & 7 a. $\mathrm{m}_{\ldots} \ldots$ & 26.3 \\
\hline \multirow[t]{2}{*}{ June 16 - } & 6 a. $\mathrm{m}$ & 19.6 & July 13 & 6.30 a.m... & 20.5 \\
\hline & 7.30 p.m. & 27.7 & & $6 \mathrm{p} . \mathrm{m}$ & 13.5 \\
\hline \multirow[t]{2}{*}{ June 17} & $5.30 \mathrm{a} . \mathrm{m}$ & 28.7 & July 14 & 5 a. $\mathrm{m}_{\ldots}$ & 8 \\
\hline & 7 p. m $\ldots$ & 29.6 & July 15 . & 5 a. m $\ldots$ & 4.9 \\
\hline
\end{tabular}


It is seen that the river was at a high stage at Independence from April 24 to July 13. It reached a maximum of 31.5 feet on April 26, a second maximum of 41.5 feet on June 5 , a third maximum of 37.4 feet on June 19, a fourth maximum of 31.9 feet on July 4, and a fifth maximum of 43.2 feet above low water-the largest of the yearon July 8. There was a range of stage at this place of about 43 feet, as compared with a range of 22 feet on the Neosho at Iola and 36 feet on Fall River at Fall River. It is seen further that the changes of stage, though larger, are not as rapid on the Neosho as on Fall River, where a change in stage of 6 feet in two hours was observed during the July flood of 1904 .

Mr. F. N. Gorden, pump engineer of the Independence waterworks, has high-water marks of the floods of $1885,1895,1903$, and 1904 on the pump house, from which the comparative heights of these floods have been obtained and the gage height at the station near Liberty on July 8 was computed. The elevations of the highwater marks above low water were as follows: July 8, 1904, 43.2 feet; June 5, 1904, 41 feet; 1903, 41 feet; 1895, 38 feet; 1885, 37.7 feet.

The Verdigris makes a $U$-shaped bend in passing Independence. The major part of the flood water cut across this bend and greatly retarded the flow in the channel proper during the flood. Mr. F. N. Gorden describes the river at the pump house as being nearly as still as a lake during the highest water, while before the water cut across the bend it was flowing with quite rapid velocity. This reduction of velocity in the main channel after overflow begins makes it very difficult to compute the flood discharge of the stream. The water begins to overflow the bottom land opposite Independence at a height of about 35 feet above low water, or 8 feet below the high water of July, 1904. The width of the flooded portion in the vicinity of Independence was about 3 miles. Wheat is the chief crop grown in this river bottom in this vieinity, and the part of the wheat that had been cut prior to these floods was piled up against the hedges and resembled in some places small straw stacks. From the flood heights, as shown by the gage heights and high-water marks at Independence and the flood heights and rating curve of the gaging station at Liberty, the flood discharge of the Verdigris at Liberty on July 8, 1904, has been computed. The overflow portion of the flood is estimated to have been 12,500 cubic feet per second and the total discharge 50,400 cubic feet per second.

\section{FLOOD ON THE LOWER VERDIGRIS.}

A considerable amount of damage was done by the floods in the vicinity of Coffeyville. A portion of the city was flooded, in addition to the loss of crops in the bottoms. The high water decreased from the Kansas and Indian Territory line to the mouth of the stream. 
FLOOD IN LOWER FALL RIVER VALLET.

The fluctuations of the surface of Fall River during the floods of 1904 can be seen from the following gage readings, taken at the gaging station at Fallriver, from which the flashy character of this stream is easily seen:

Gage height of Fall River at Fallriver, Kans., 190;.

\begin{tabular}{|c|c|c|c|c|c|}
\hline Date. & 7 a.m. & 5p.m. & Date. & 7 a.m. & 5p.m. \\
\hline & Feet. & Feet. & & Feet. & Feet. \\
\hline April 22 . & 3.5 & 3.5 & June 20 & 8 & 7.1 \\
\hline April 23. & $\ldots$ & 4 & June 21 & 9.2 & 6. 4 \\
\hline April 24 & 26.3 & 29.5 & June 22. & 6 & 5.4 \\
\hline April 25 . & 14.5 & 12.5 & June 23. & 9 & 5.2 \\
\hline April 26 & 9.3 & 7.3 & June 24 & 5 & 4.8 \\
\hline April 27 . & 6.5 & 6.1 & June 25 & 10 & 18.5 \\
\hline April 28 & 6.1 & 6 & June 26 & 11.2 & 8 \\
\hline April 29 & 5.9 & 5.8 & June 27 & 18.5 & 9 \\
\hline April 30 & 5.7 & 5.7 & $\operatorname{June} 28$ & 8 & 7.2 \\
\hline May 31 .. & 7 & 6.4 & June 29 & 7.5 & 18 \\
\hline June $1 \ldots$ & 8 & 18.3 & June 30 & 19 & 9.5 \\
\hline June 2 & 9.5 & 10.5 & July 1 & 7.5 & 16.2 \\
\hline June 3. & 24 & 27.5 & July $2 \ldots$ & 20 & 24.5 \\
\hline June $4 \ldots$ & 33.5 & 25.4 & Jaly 3 & 12.5 & 8 \\
\hline June $5 \ldots$ & 12.5 & 10.3 & July 4 .. & 8 & 16.4 \\
\hline June 6... & 8.4 & 7.5 & July 5 . & 9 & 21.5 \\
\hline June 7 & 6.8 & 6 & July 6 . . & 32.5 & 33.6 \\
\hline June 8 & 5.5 & 5.5 & July $7 .$. & 30 & 31.5 \\
\hline June 9 & 13.5 & 8.8 & July $8 \ldots$ & 31 & .15 .1 \\
\hline June 10. & 23.5 & 34.8 & July 9 & 10.4 & 10 \\
\hline June 11. & 31 & 20.7 & July 10 & 9 & 18.4 \\
\hline June 12 & 10 & 8.5 & July 11 & 14 & 9 \\
\hline June 13 & 8 & 7.4 & July $12 \ldots$ & 7.5 & 7 \\
\hline June 14 & 13.2 & 8.5 & July $13 \ldots$ & 6.5 & 6.2 \\
\hline June 15.. & 9 & 7.8 & July $14 \ldots$ & 6 & 6 \\
\hline June 16. - & 37.8 & 35.6 & July $15 \ldots$ & 5 & 15.4 \\
\hline June 17. & 27.5 & 17 & July 16 & 8 & 6.5 \\
\hline June 18 & 10.4 & 7.5 & July $17 \ldots$ & 5 & 4.8 \\
\hline June 19 & 8.2 & 16 & & & \\
\hline
\end{tabular}

It is seen that this stream reached a maximum stage on April 24 of 29.5 feet, reached a second maximum on June 4 of 33.5 feet, a third maximum on June 10 of 34.8 feet, a fourth maximum on June 16 of 37.8 feet, and a fifth maximum on July 6 of 33.6 feet, in addition to 
smaller maximum stages between the larger ones. On the evening of April 23 the gage read 4 feet; the next morning it read 26.3 feet-a rise of 24.3 feet in ten hours. On the evening of June 15 the gage read 7.8 feet; the next morning it read 37.8 feet-a rise of 30 feet in ten hours. There were six floods of this stream from April 23 to July 8 in which the gage read from 22 feet and four when it read above 35 feet.

This flashy character of Fall River is due to the steep, impervious nature of the watershed.

These floods caused little overflow above the station, but at Fredonia and Neodesha an area of from 2 to 5 miles in depth was submerged by the four highest floods, and the crops on the submerged land were destroyed. Less stock was lost in these floods than in any recent flood of equal magnitude, because of the warnings telephoned and telegraphed from the station to the property owners down the valley.

There are high-water marks at the Frisco Railroad pumping station near the gage- - one of 1898 and one of 1869. The flood of June 3, gage height 35.5 at 3 a. m., came to the mark of 1898 , and the flood of June 10 , gage height 36.8 feet at $9 \mathrm{p}$. m., came above that of 1869. The flood of June 16 was from 3 to 4 feet higher than any previous known flood.

\section{NECESSARY WIDTH OF CHANNEL OF VERDIGRIS RIVER.}

The average slope of Verdigris River for 150 miles from the mouth is less than 2 feet per mile, and there are long stretches where it is not more than 1 foot per mile. This is a very small slope for a small stream. The frequent overflows are due almost entirely to the small slope and consequent sluggish flow. The only practical remedy for overflow is the construction of levees on each side of the river where overflow takes place, at such a distance apart that there will be ample room for the passage of floods between them.

If the flood volume, the height of floods above low water, and the slope of the stream are known, it is possible to compute the area of waterway to pass the maximum flow without overflow.

The flood of 1904 had a maximum rate of discharge at Independence of 50,400 cubic feet per second and the height of the flood above low water was about 40 feet. With these data and the assumption that the slope is 1.5 feet per mile and the coefficient of roughness of bed 0.030 , we find that a channel of trapezoidal cross section having a bottom width of 105 feet and a top width of 225 feet will carry a volume of 50,500 cubic feet per second, and the mean velocity of flow will be about 7.6 feet per second. The channel cross section at the gaging station on the highway bridge near Liberty has a bottom width 
of about 150 and a top width of about 275 feet, so that if the slope of the river were 1.5 feet per mile during floods, this channel would carry the water without the stage reaching the height of 40 feet above low water; but, unfortunately, the slope decreases as the stage increases. The mean velocity should be 7.2 feet, but it probably was less than $\check{5}$ feet per second.

DAMAGE DONE BY FLOOD.

The damage done by the flood along this river consisted mainly of loss of crops, du to overflow of the bottom land. Part of the wheat crop was in shock at the time of the first high flood, and this was carried off the fields and piled up against the fences. That part of the wheat crop that was standing was injured to such an extent that little of it was harvested; in fact, the crops on all the area flooded were destroyed. Little damage was done to the ground itself, as the velocity was not sufficient to cause scour. There was little loss of stock, owing mainly to the very efficient way in which the high water was predicted from the flood stations.

\section{OSAGE RIVER FLOODS.}

\section{STREAM AND DRAINAGE BASIN.}

Osage River rises in the northeastern part of Wallace County, Kans., flows in a general easterly direction, and empties into Missouri River near Osage City, Mo. The distance from the source to the mouth in a straight line is about 210 miles, but the length of the river is at least 400 miles, as it is very crooked for a considerable part of its course. It falls from an elevation of about 1,225 feet to 755 feet, near Ottawa, in a distance of about 50 miles; but for a distance of about 25 miles on either side of Ottawa the fall is not more than $1 \frac{1}{2}$ feet per mile. From Ottawa to the mouth of the river there is a fall of about 330 feet in 434 miles. The stream flows in a fairly deep channel, that changes little from year to year, as the soil contains a considerable amount of clay; but it overflows frequently, due to very heavy rainfall and sluggish flow.

The watershed above the gaging station at Ottawa has an area of 1,237 square miles, its greatest length being about 55 miles and its greatest width 27 miles. It is hilly or gently rolling, and consists of pasture and cultivated lands, with little tree growth except along the streams.

GAGE HEIGH'T AND DISCHARGE.

A gaging station was established at Main Street Bridge, Ottawa, August 26, 1902. The chamnel is nearly straight for about 100 feet 
above and 75 feet below the station, and has a width between abutments of about 138 feet, without piers. The bed is rock and gravel and is permanent. The flow is moderately rapid. Although the channel is deep, both banks are subject to overflow during floods. Fluctuations of the surface are measured with a chain gage fastened to the bridge. The mean daily gage height and corresponding discharge obtained at this station from readings each morning and evening during the floods of 1904 are given below :

Gage height and discharge of Osage River at Ottawa, Kans., May, June, and JuTy, 1904.

\begin{tabular}{|c|c|c|c|c|c|}
\hline Date. & $\begin{array}{c}\text { Gage } \\
\text { height. }\end{array}$ & Discharge. & Date. & $\begin{array}{c}\text { Gage } \\
\text { height. }\end{array}$ & Discharge. \\
\hline May 15 & $\begin{array}{l}\text { Feet. } \\
3.10\end{array}$ & $\begin{array}{r}\text { Sec. feet. } \\
1,450\end{array}$ & June 8 & $\begin{array}{l}\text { Feet. } \\
3.25\end{array}$ & $\begin{array}{r}\text { Sec. feet. } \\
\quad 1,630\end{array}$ \\
\hline May 16 & 20.35 & a 22,140 & June 24 & 2.65 & 920 \\
\hline May 17 & 24.25 & 26,820 & June 25 & 16.45 & 17,460 \\
\hline May 18 & 23.05 & 25,380 & June 26 & 22.90 & 25,200 \\
\hline May 19 & 9.15 & 8,700 & June $2 \tau_{-}$ & 26.25 & 29,220 \\
\hline May 20 . & 3.40 & 1,810 & June 28 & 25.00 & 27,720 \\
\hline May 21 & 3.10 & 1,450 & June 29 & 10.40 & 10,200 \\
\hline May 25 & 2.40 & 650 & June 30 & 8.30 & 7,680 \\
\hline May 26 & 7.00 & 6,120 & July 1 . & 8.30 & 7,680 \\
\hline May $2 \tau$ & 9.40 & 9,000 & July 2 & 5.85 & 3,550 \\
\hline May 28 & 4.90 & 3,610 & July $3 \ldots$ & 6.10 & 5,040 \\
\hline May 29 & $(b)$ & & July 4 & 7.35 & 6,540 \\
\hline May 30 & 31.80 & 35,880 & July 5 & 4.95 & 3,670 \\
\hline May 31 & $c 30.00$ & 33,720 & July 6 & 19.60 & 21,240 \\
\hline June 1 & 28.00 & 31,560 & July $\tau_{-\ldots}$ & 25.55 & 28,380 \\
\hline June 2 & 26.40 & 29,400 & July 8 & 30.15 & 33,900 \\
\hline June 3 & 24.60 & $2 \pi, 240$ & July $9 \ldots$ & 29.50 & 33,120 \\
\hline June 4 & 24.75 & 27.420 & July 10 & 27.25 & 30,420 \\
\hline June 5 - - & 24.45 & 27,060 & July 11 & 17.45 & 18,660 \\
\hline June 6 & 17.00 & 18,120 & July 12 & 4.65 & 3,310 \\
\hline June $7 .$. & 5.95 & 4,860 & & & \\
\hline
\end{tabular}

"Discharges for stages above 20 feet are very doubtful and are probably too small.

${ }^{b}$ Record lost, owing to high water.

c Gage heights from May 31 to June 2 obtained by interpolation.

It is seen that there were three floods at this place from June 30 to July 10 -one that reached a mean daily stage of 31.8 feet and discharge of 35,880 second-feet on May 20; a second that reached a mean daily stage of $26 \frac{1}{4}$ feet and discharge of 29,220 second-feet on June 27 ; and a third that reached a mean daily stage of 30.2 feet and discharge of 33,900 second-feet on July 8 . The maximum stage reached for a short time on May 10 was 34.3 feet. 
The flashy character of this stream can easily be seen from the rapid fluctuation in stage and discharge.

'The greatest flood on this stream prior to 1904 , in the recollection of the oldest inhabitants living along it, was in May, 1898, the highest stage reached at Ottawa being about 29 feet. The first flood of 1904-that of May 30-reached a stage at Ottawa of 34.3 feet, that is, about 5 feet higher than the 1898 flood. The second flood of 1901 - that of June 27 -reached a stage at Ottawa of 26.6 feet, that is, to within $2 \frac{1}{2}$ feet of the flood of 1898 . The third flood of 1901 -that of July 8-reached a stage of 30.7 feet, that is, 2 feet higher than the flood of 1898 .

Each of these floods was due to very heavy rainfall following a period of excessive precipitation. The rainfall for May, 1904, was 11.68 inches, and the rainfall in the twenty-four hours just preceding the flood was 5.20 inches. In May, 1898, when the previous great flood occurred, the rainfall for May was 11.67 inches, and the rainfall for the twenty-four hours just preceding the flood was 4.06 inches.

\section{DAMAGE DONE BY FLOODS.}

The 1904 floods on this river appear to have been higher and did more damage in the vicinity of Ottawa than anywhere else along the stream. The damage done was due mainly to the water overflowing and standing on the ground, and very little to scouring action. About 250 houses in Ottawa were flooded and their occupants driven out. The city water, gas, and electric-light plants were flooded and the city left without water and light for several days. The water stood $1 \frac{1}{2}$ feet in depth on the floor of the Santa Fe Railway station, and about 3 inches in depth on the floor of the Missouri Pacific Railway station. Railway traffic was suspended for about three days. The river bottom was flooded for several days for a width varying from one-fourth mile to 2 miles, and all the crops in the overflowed portion were destroyed. Some stock in the river bottoms was destroyed; also numerous fruit trees, especially the smaller ones. The water passed over the three bridges in Ottawa, but none of them was injured to any great extent. The water was 3 feet in depth on Main Street Bridge, where the gage is located.

The second flood, which reached its height about June 27 at a gage height of 26.6 feet-that is, 7.7 feet lower than that of May 30was commented on by the Ottawa Republic as follows:

While the area covered in Ottawa by this flood is considerable, not so many families have been compelled to move as ordinarily have in the case of floods of equal height, for the reason that the big flood caused a score or more of lowly homes to be washed away that never have been replaced.

During the third flood, which reached its height July 8 at a gage height of 30.7 feet, the city's supplies of water and gas were again cut 
off. Many persons were driven from their homes. Business and railway traffic were nearly suspended for a few days.

\section{PREVENTION OF FUTURE DAMAGE.}

The area of waterway at Main Street Bridge, Ottawa, is about 4,000 square feet to the lower surface of the bridge. The overflow area here was probably at least 6,000 square feet. The actual area provided for passing the discharge of this stream is, therefore, not more than 40 per cent of the water area on May 30,1904. The Atchison, Topeka and Santa Fe Railway crosses the river on an embankment. The water overflowed this road and wore holes several cubic yards in capacity in some places, showing that there was a considerable difference in elevation of the water on the upstream and downstream sides of the embankment and that the embankment acted as a dam. Large trees grow close to the water's edge along this stream. These trees, while they served to protect the banks from erosion, retarded the flow, and drift collected in front of them, forming a dam. Conclusive evidence of this action can be seen a short distance above the upper bridge in Ottawa. This is a crooked stream, with rather sluggish flow, and if the flood height is to be reduced to a minimum the flow should not be obstructed by bridges, embankments, trees, and the like.

\section{ARKANSAS RIVER FLOODS,}

GAGE HEIGHT AND DISCHIARGE.

The floods on Arkansas River from Wichita to Arkansas City were greater in 1904 than ever known before. Maximum fluctuations of the river surface from May 30, 1889, to July, 1904, given by the Unitêd States Weather Bureau gaging station on Douglass Avelue Bridge, at Wichita, are given below:

Maximum stages of Arkansas River at Wichita, Kans.

\begin{tabular}{|c|c|c|c|}
\hline Date. & $\begin{array}{c}\text { Gage } \\
\text { height. }\end{array}$ & Date. & $\begin{array}{c}\text { Gage } \\
\text { height. }\end{array}$ \\
\hline & Feet. & & $\begin{array}{l}\text { Feet. } \\
6.0\end{array}$ \\
\hline May 3,1889 & 5.3 & April 13, 1901 & 6.0 \\
\hline June 10, 1889 & 5.6 & June $9,1901 \ldots$ & 4.3 \\
\hline June 10,1899 . & 6.3 & June 3, 1902 & 5.9 \\
\hline April 22,1900 . & 7.0 & June 2, 1903 & 7.6 \\
\hline May $28,1900 \ldots$ & 7.4 & June 4, 1904 . & 6.0 \\
\hline June $8,1900 \ldots$ & 7.2 & July 9,1904 & 10.2 \\
\hline
\end{tabular}

It is seen that the July 9, 1904, flood was 2.6 feet higher than any previous flood since the gaging station was established, but this differ- 
ence in gage height between the floods of 1904 and other floods does not convey an adequate idea of the difference in volume. The recorded range of stage of the Arkansas at Wichita is only about 10.5 feet, whereas the range of stage of the Neosho at Iola is 22 feet, that of Fall River at Fallriver is 36 feet, and that of the Verdigris at Independence is 43 feet. Yet the change in volume of the Arkansas is from 70 to 40,000 second-feet, whereas the change in volume of the Verdigris is only from 30 to 50,400 . Arkansas River flows in a relatively wide, shallow channel, with low banks and sandy, changeable bed, with a considerable fall and rapid velocity, making it impossible for the change of stage to be as great as that of the Verdigris or the Neosho, on account of the shallow channel and steep slope.

FLOOD NEAR ARKANSAS CITY.

The fluctuations of the surface of the Arkansas at Arkansas City during the floods of 1904 and the corresponding discharge are given by the gage readings below, taken at the United States Geological Survey gaging station in Arkansas City:

Gage height and discharge of Arkansas River flood at Arkansas City. June 1 to 8 and July 1 to $18,1904$.

\begin{tabular}{|c|c|c|c|c|c|}
\hline Date. & $\begin{array}{c}\text { Gage } \\
\text { height. }\end{array}$ & $\begin{array}{c}\text { Dis- } \\
\text { charge. }\end{array}$ & Date. & $\begin{array}{c}\text { Gage } \\
\text { height. }\end{array}$ & $\begin{array}{c}\text { Dis- } \\
\text { charge. }\end{array}$ \\
\hline June 1 - & $\begin{array}{c}\text { Feet. } \\
\text { 6. } 20\end{array}$ & $\begin{array}{c}\text { Sec. feet. } \\
3,200\end{array}$ & July 6 & $\begin{array}{l}\text { Feet. } \\
10.50\end{array}$ & $\begin{array}{r}\text { Sec. feet. } \\
13,955\end{array}$ \\
\hline June $2 \ldots$ & 8.10 & 7,125 & July $7 \ldots$ & 13.30 & 27,347 \\
\hline June 3 & 11.20 & 14,440 & July 8 & 14. 20 & 33,503 \\
\hline June $4_{-\ldots}$ & 12.90 & 21,470 & July 9 & $14.90^{-}$ & 38,291 \\
\hline June 5 & 13.30 & 24,100 & July 10 & 15.20 & 40,355 \\
\hline June 6 & 10.80 & 13,290 & July 11 & 14.50 & 35,555 \\
\hline June 7. & 8.90 & 8,810 & July 12 & 13.80 & 30,767 \\
\hline June 8 . - & 8.10 & 7,125 & July 13 & 12.50 & 21,875 \\
\hline July 1 . . & 7.00 & 4,355 & July 14 & 11.80 & 17,855 \\
\hline July 2 & 6.60 & 3,555 & July 15 & 9.20 & 10,055 \\
\hline July 3. & 7.50 & 5,445 & July 16 & 8.10 & 6,915 \\
\hline July 4 & 8.70 & 8,565 & July $1 \%$ & 7.20 & 4,775 \\
\hline July 5 . & 9.50 & 10,955 & July 18 & 7.00 & 4,355 \\
\hline
\end{tabular}

It is seen that two floods occurred here this season-one that reached its maximum on June 5, with a gage height of 13.3 feet, and another that reached its height on July 10, with a gage height of 15.2 feet and a discharge of 40,355 second-feet. The ordinary gage reading of low water at Arkansas City is about 2 feet, so that these flood crests are 11.3 and 13.2 feet, respectively, above low water. There is 
a difference of only about 2 feet in the elevation of the crests of these floods at Arkansas City, whereas the difference in elevation of the crests at Wichita is about 4 feet. This is partly due to the flood of the Little Arkansas at Wichita, and to the greater facility for spreading out over the valley at Arkansas City. Both banks at the latter place are low and subject to overflow. A levee of sand banks on the right side prevented overflow of that bank, but the left bank was submerged for half a mile from the river. The maximum depth of this overflow on July 10 was about 5 feet. The area of overflow was 7,205 square feet, and the total flood area $11,28 \tau$ square feet. The total discharge was 40,335 cubic feet per second. The flood of July remained for five days higher than ordinary floods, and being about 2 feet higher destroyed a much larger area of the river bottom than ever before. A pile bridge across the river at Arkansas City was swept away by the flood.

FLOOD NEAR WICHITA.

The fluctuations of the surface of Arkansas River at Wichita and Hutchinson, furnished by Mr. George T. Todd, United States weather forecaster, are as follows:

Gage height of Arkansas River at Wichita and Hutchinson, Kans., July 2 to 18, 190\%.

[United States Weather Bureau record.]

\begin{tabular}{|c|c|c|c|c|c|}
\hline Date. & Wichita. & $\begin{array}{l}\text { Hutchin- } \\
\text { son. }\end{array}$ & Date. & Wichita. & $\begin{array}{l}\text { Hutchin- } \\
\text { son. }\end{array}$ \\
\hline July $2 \ldots$ & $\begin{array}{l}\text { Feet. } \\
\quad 3.2\end{array}$ & $\begin{array}{l}\text { Feet. } \\
\quad 3.4\end{array}$ & July 11.. & $\begin{array}{l}\text { Feet. } \\
8.6\end{array}$ & $\begin{array}{l}\text { Feet. } \\
\quad 2.8\end{array}$ \\
\hline July $3 .$. & 4.6 & 3.2 & July 12. & 7.6 & 2.7 \\
\hline July 4 . & 4.3 & 3.4 & July 13 & 6.3 & 2.7 \\
\hline July 5 & 5.5 & 3.9 & July 14 & 4.8 & 2.6 \\
\hline July 6 . & 7.1 & 4.9 & July $15 \ldots$ & 3.9 & 2.6 \\
\hline July 7. & 9.1 & 4.7 & July 16 & 2.8 & 2.6 \\
\hline July 8 & 10.1 & 4.2 & July 17 & 2.3 & 2.5 \\
\hline July 9 & 10.2 & 3.8 & July $18_{-}$ & 1.9 & 2.5 \\
\hline July 10 & 9.7 & 3.0 & & & \\
\hline
\end{tabular}

Note.-Crest of 1904 flood was about 2 feet higher than that of 1903 and a little higher than crest of 1879 flood.

The low-water gage reading at Wichita is -0.6 foot, so that the excess of the July flood was about 10.8 feet above lowest low water.

Flood marks here indicate that the flood of 1877 did not reach as great an elevation as the flood of July 8, 1904. About three-tenths of the city of Wichita was submerged during the larger of the two 
floods. Indeed, it appeared on the night of July 8 that about ninetenths of the city was under water, but the greater part of this water came from a very heavy rain, and not from streams.

The larger part of the overflow came from Little Arkansas River and Chisholm Creek. This creek traverses a considerable portion of the city, but its waterway there was not sufficiently large to carry the flood safely, and the area on each side was flooded. The Little Arkansas is very crooked and empties into the Arkansas where the channel is very narrow. As a result of this, the water backed up and submerged a considerable portion of the city in that vicinity. There are seven bridges across the Arkansas within the city limits of Wichita, and each of them, with the single exception of the Douglass Avenue Bridge, rests on piles, which collected the drift, retarded the flood, and caused overflow.

The damage in the city due to the overflow is estimated to be about $\$ 30,000$. All the railway tracks in the vicinity were under water and traffic greatly delayed or suspended. The farmers, however, living along the river valley suffered to the greatest extent, as all the crops on the submerged land were destroyed.

The gage readings at Hutchinson, given above, show that the flood was very small at this place.

\section{FLOOD ON WALNUT RIVER.}

Walnut River rises in the southern part of Marion County, flows south and empties into Arkansas River near Arkansas City. Its length from source to mouth in a straight line is about 75 miles. It falls from an elevation of about 1,410 feet to 1,030 feet at its mouth. Its watershed joins that of the Cottonwood on the north, of the Verdigris on the east, and of the Arkansas on the west. Its greatest width is about 35 miles, and its area is about 946 square miles. It consists of gently rolling pasture or cultivated land, with little timber except along the river banks.

The rainfall and floods of this river in 1904 were greater than ever known before. There is a gage on the downstream side of one of the piers of the Frisco Railroad bridge in Winfield, also highwater marks on this bridge and the machinery room of a mill near by, from which the following data in regard to the floods of 1904 and previous floods have been obtained.

Four great floods have occurred here in the recollection of the inhabitants-those of 1877, 1898, June 4, 1904, and July 8, 1904.

The high-water mark of 1898 was surpassed by $25 \frac{1}{2}$ inches in the flood of July 8, 1904, and by $14 \frac{1}{2}$ inches in that of June 4, 1904 . The marks of the 1877 flood are not very distinct, but the general belief is that the flood of July 8, 1904, was somewhat higher than that of $187^{\top}$, 
as the highway bridge at Winfield was built above the high-water mark of that flood, and the water in July, 1904, was 8 inches in depth on the floor of this bridge.

\section{PENNSTLVANIA FLOODS.}

By E. C. Murphy.

Floods of short duration, due to heavy downpour of rain, have occurred at a number of places on comparatively small streams with steep, narrow channels, during the past year. Two of these, namely, Robinson Run and Johnstown, both in Pennsylvania, will be described in this paper. They illustrate the need of providing an ample way for such streams and of keeping it always open. Sooner or later the damage caused by such floods will much more than offset the small gain due to encroachments on the natural width of the stream.

\section{JOHNSTOWN FLOOD.}

Damage amounting to several thousand dollars was done at Johnstown, Pa., by a very heavy downpour of rain on Saturday evening, July 8,1904 . During the twenty-four hours ending at 8 a. m. July $9,2.98$ inches of rain was measured at the United States Weather Bureau station, of which 1.45 inches fell between 8 and $9.30 \mathrm{p} . \mathrm{m}$. on the 8th. This rain fell so very rapidly that the street gutters could not carry off the water with sufficient rapidity, and the streets were flooded, sewers clogged, and basements and cellars of houses entered. The hills surrounding Johnstown are very steep; the minor streams, one-half mile to 2 miles in length, that are ordinarily dry became very much swollen and, passing down the steep hillsides, carried large amounts of gravel and bowlders that quickly choked culverts and other waterways, causing overflow into the streets and surrounding territory.

The flood down Bedford street is thus described in the Johnstown Tribune:

The occasion of all the damage on Bedford street was the little streamcrdinarily the merest rivulet-which drains Meyers Hollow. The cloud-burst of Saturday night converted this brooklet into a raging flood which tore down Brown avenue to Bedford street, bearing with it tons of earth, rocks, and logs. Its first onslaught was on the house of D. B. Parker, the lower floor of which was almost instantly covered to a depth of 3 feet with slimy mud. From here the flood swept on down Bedford street to the corner of Main, where it formed a veritable lake. As usual, the cellars of the Merchants' Hotel, Nathan's, and Swank Hardware Company were attacked, and with the exception of Swank's, where an electrical pump kept ahead of the influx, were pretty well flled.

The quantity of material brought down by these streams delayed the street cars for several hours. Traffic on the Pennsylvania Rail-

IRR $147-05 \mathrm{M}-8$ 
road was delayed for ten hours by the landslide at Buttermilk Falls, all four of the tracks being covered to a depth of several feet.

The rainfall which caused this damage, though large, was local, as shown by the flow of the larger streams. The readings of the United States Weather Bureau gage at Franklin Street Bridge, Johnstown, on Stony Creek, show very little change of stage.

Gage height at Johnstoun, Pa., 1904.

\begin{tabular}{|c|c|c|c|}
\hline Date. & $\begin{array}{l}\text { Height } \\
\text { in feet. }\end{array}$ & Date. & $\begin{array}{l}\text { Height } \\
\text { in feet. }\end{array}$ \\
\hline July 8 & 3.6 & July 11 & 3.6 \\
\hline July 9 & 3.5 & July $12 \ldots$ & 3.0 \\
\hline July 10 & 5.4 & July 13 & 2.8 \\
\hline
\end{tabular}

It is easily seen that this damage was not due to overflow of the principal streams, but to that of the minor streams, and to the fact that the street gutters in the low part of the city were not large. enough to carry off the water that fell on the streets.

\section{ROBINSON RUN FLOOD. $a$}

On June 28, 1904, there occurred a flood on Robinson Run that did much damage to property along its banks, especially in Oakdale, Pa.

This stream is a comparatively small one that rises about 20 miles west of Pittsburg, Pa., flows in a southeasterly direction, and empties into Ohio River about 2 miles west of Pittsburg. Its principal tributary is Robb Run, which enters it near Oakdale. The watershed has steep, uncultivated slopes, with little timber. The stream has a steep slope and a rapid run-off. The Pennsylvania Railroad runs along Robinson Run from Walkers to Oakdale, thence along Robb Run to beyond McDonnell.

The flood occurred on the evening of June 28. During the day there were occasional heavy showers, and from 6 to 7 in the evening it rained very heavily, especially along the north branch of Robinson Run. As a result these two streams, especially Robinson Run, were transformed into raging torrents.

Some damage was done at McDonnell on Robb Run. This creek rose to flood stage in about fifteen minutes and was back again to near its normal stage in about two hours. It overflowed its banks, filling cellars. with water, damaging furniture, and carrying away sidewalks and a few small bridges.

The flood on Robinson Run was much larger than on Robb Run. 
Its height at Oakdale was due, in part at least, to the obstruction of the channels in and just below the town, where it was badly obstructed by the railway bridge. The water was about 15 feet deep in the creeks at Oakdale and 7 feet deep on the floor of the Oakdale Times office. All the buildings in the lower part of the town along the creek were flooded. Sixty families lost their furniture and 11 houses were either destroyed or very badly injured. Some of the business houses lost a considerable amount of stock, damaged by the water. Three bridges across Robinson Run in the vicinity of Oakdale were destroyed, also other bridges farther down the creek. The total loss was estimated to be about $\$ 30,000$, one-half of which was for bridges.

\section{TROXTON CANYON FLOOD, ARIZONA. $a$}

By E. C. MurPhy.

Floods of great magnitude and destructiveness occurred in western Arizona on the headwaters of the Big Sandy, a tributary of the Williams, and on Sacramento Wash, a small tributary of Colorado River, in the latter part of July and August, 1904.

The gorge commonly known as Troxton Canyon is about 3.5 miles long and is located about 40 miles northeast of Kingman, Ariz. The country is mainly a barren, treeless, elevated plateau with an occasional low range of mountains, through one of which, known as Cottonwood Cliffs, the Big Sandy has cut its way, forming the gorge in question. This is crooked and its bed has a very steep slope. The Santa Fe Railway passes through it, crossing it at several points on steel bridges.

The stream in this canyon is usually dry, but on July 30 it had a depth at one of these bridges of more than 30 feet and a very high velocity. The stream remained at maximum stage about half an hour.

The nearest place to the canyon where precipitation is measured is Kingman, Ariz. The records there show a rainfall in July of 0.79 inch. The precipitation over the greater part of western Arizona in August varied from 2 to 9 inches in depth, being 6 inches or more above the normal at some places. Unfortunately, so far as known, no measurements of stage or discharge of the floods were made along either of these streams in July or August.

Five steel bridges of approved construction, built since 1898, cross the stream in the canyon. Two of these, of 80 feet span, were destroyed by the flood; two others of 80 feet span were not destroyed, but the water and drift passed over them; the fifth, consisting of

${ }^{a}$ Largely prepared from an article in the Railway Age by A. F. Robinson, bridge engineer of the Atchison, Topeka and Santa Fe Railway, on the damage to the railway property during the flood. 


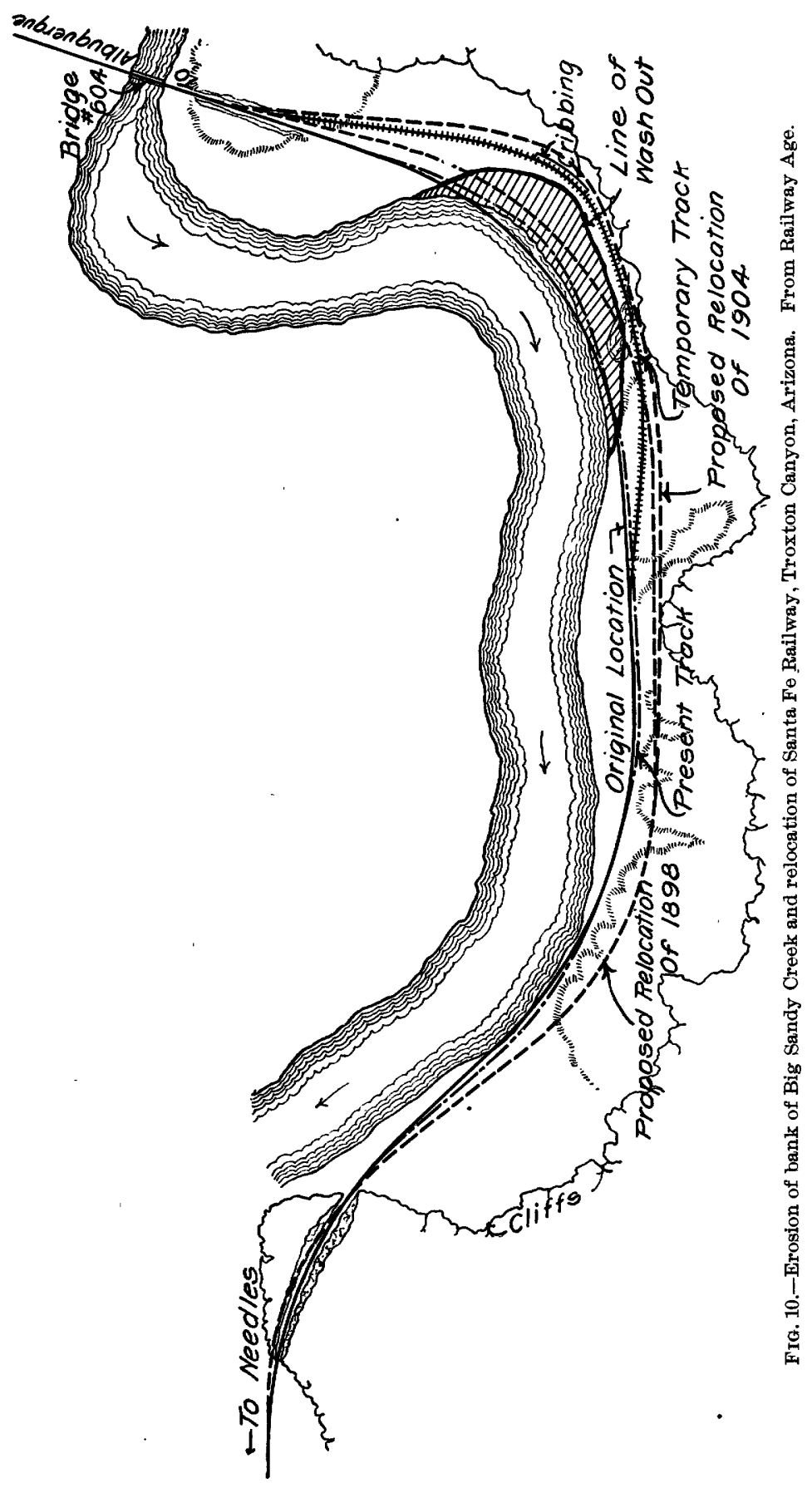




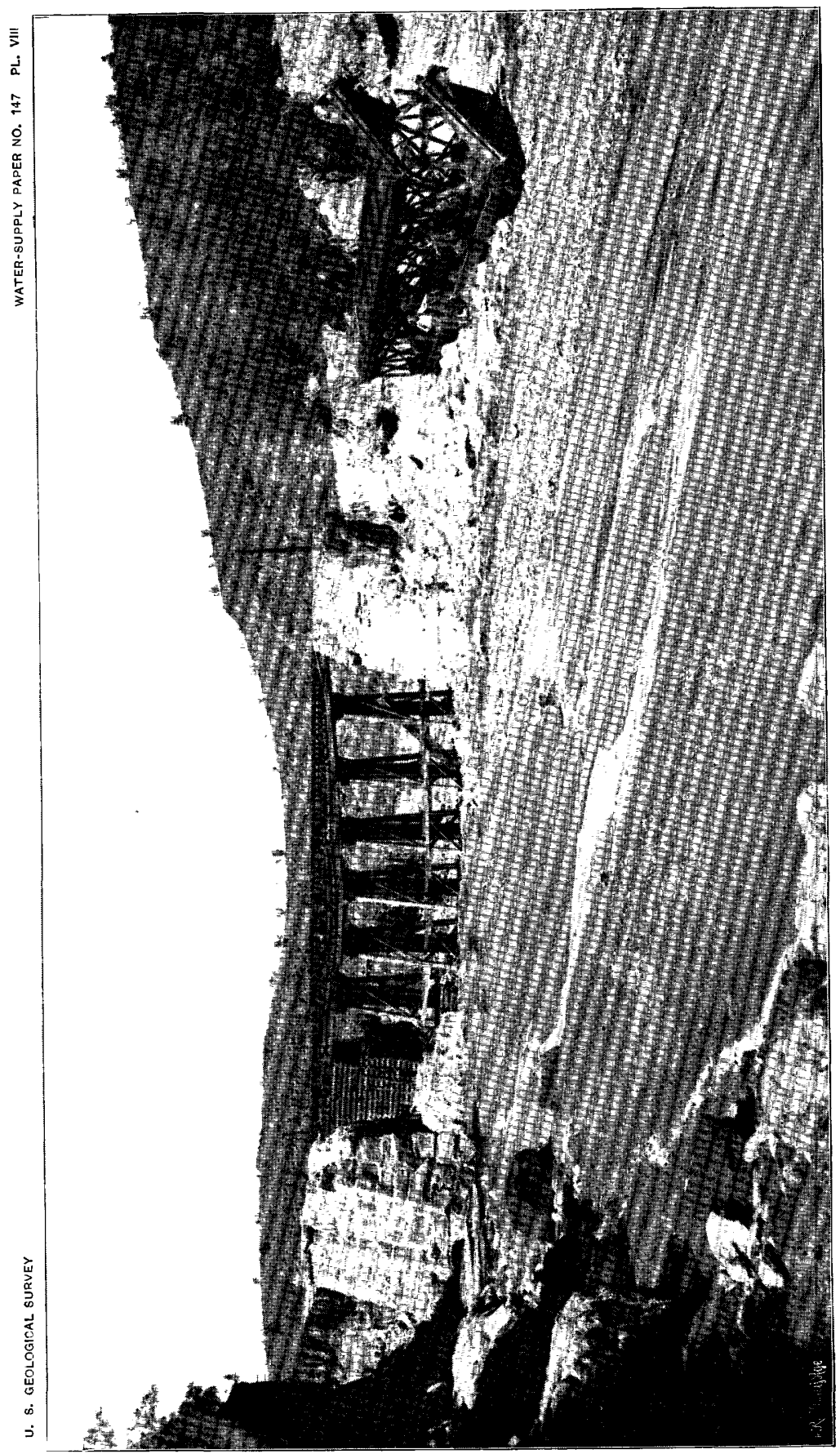

2
2
2
$z$
0
$z$
0
2
$x$

은 
three 80 -foot spans, had about 60 feet of the east approach washed out. Bridge No. 604, an 80-foot bridge, was destroyed by this flood (Pl. VIII). Although the east abutment of this bridge weighed over 600 tons, it was carried by the water about 150 feet downstream and turned through an angle of about 180 degrees. The west abutment was founded on rock, the east one on adobe, resting on a concrete footing extending 7 or 8 feet below the bed of the stream on a timber grillage. There was a protection wall at right angles to

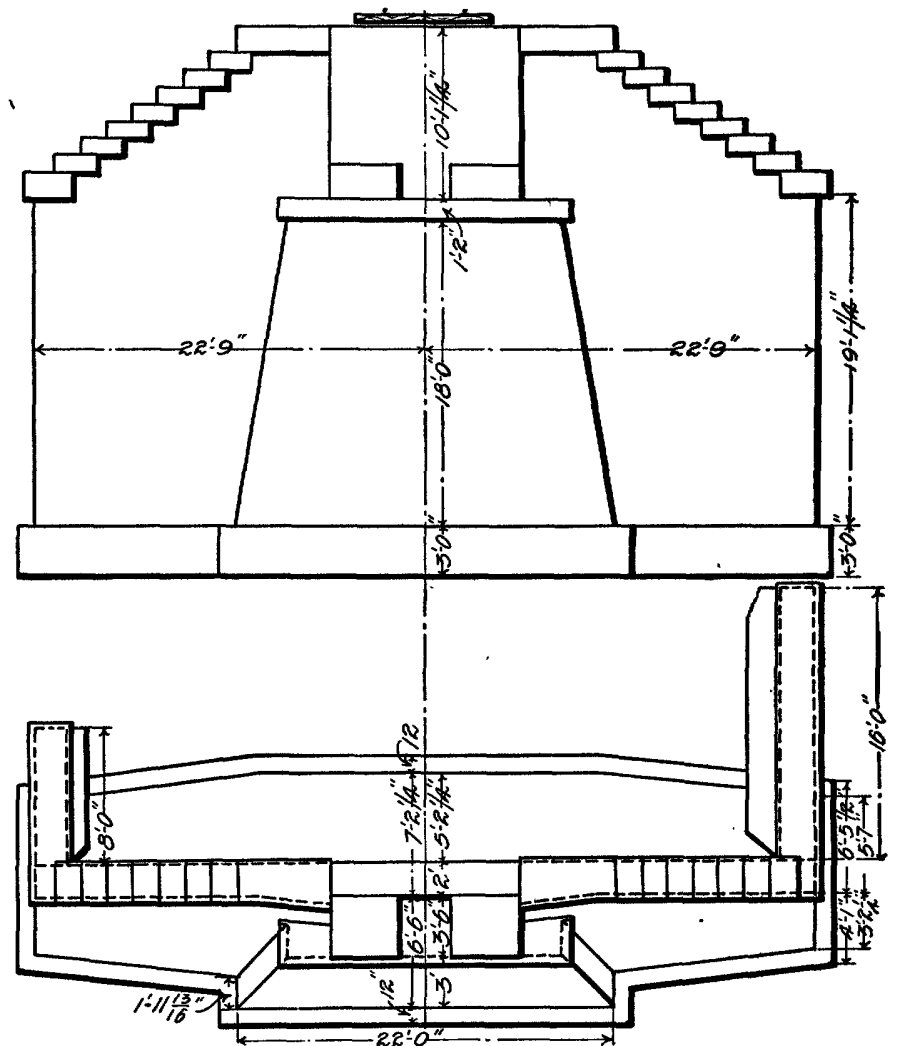

FiG. 11.-Design of east abutment of bridge No. 604, Santa Fe Railway, Troxton Canyon, Arizona. From Railway Age.

the abutment and extending about 16 feet into the bank to prevent the water from cutting around the end, but the stream cut under this and tipped it and carried away the abutment. "The protection wall was not carried down to the depth of the main part of the abutment; possibly if it had been the abutment might not have failed. The water not only destroyed this east abutment, but washed away the bank to a distance of about 35 feet. Fig. 11 shows a plan and an elevation of this east abutment; fig. 10 shows erosion of channel in the vicinity of bridge No. 604 and relocation of railway. 
During August there were almost daily floods on this stream and other streams in western Arizona, making the railroad repairs very difficult and expensive. On August 2 one of the largest of these floods occurred, doing considerable damage in this canyon and also along Sacramento Wash, through which the Santa Fe Railway passes. Between Yucca and Haviland the bridge and 600 feet of road were destroyed.

The damage caused by the flood was almost entirely to the railway line, and comprised a large loss of business, traffic being suspended fifteen days. From Los Angeles to Albuquerque for some days it was necessary for the Santa Fe trains to pass over the Southern Pacific tracks to Maricopa and thence north through Phoenix to the Santa Fe tracks.

From slopes and cross sections in this canyon taken after this flood by the Santa $\mathrm{Fe}$ engineers it has been estimated that the maximum in this canyon was approximately 49,000 second-feet.

\section{GLOBE FLOOD, ARIZONA.}

By O. T. REEDY.

The Pinal Creek flood of 1904, generally known as the Globe floorl, since both the rainfall which caused it and the greatest damage occurred in the immediate vicinity of Globe, Ariz., took place on the afternoon of August 17. The rain began to fall about $5.30 \mathrm{p.} \mathrm{m}$. in a gentle shower, which in a few minutes increased to a veritable cloud-burst, continuing without abatement for about three-quarters of an hour. Pinal Creek began to rise within fifteen or twenty minutes after the rain commenced, and reached its highest point about 6 o'clock. The storm was local, extending from the divide 5 or 6 miles to the southwest and southeast of Globe to about the northern limits of the town. The area covered was only about 25 or 30 square miles. The water all fell within an hour, and measured 2.05 inches at Gloke. In order to estimate the amount of the flood waters I took several cross sections of the creek up to the high-water mark, and also measured the slope of the creek bed. From these data, and assuming $n$, the coefficient of roughness, to be 0.025 , the discharge per second was computed by Kutter's formula. The first cross section was taken just behind Mr. A. Kinney's barn, the highwater mark being a point shown by Mr. Kinney. The discharge at this point as computed is about 11,000 feet per second, which is checked pretty closely by the computed discharge for a cross section taken 200 or 300 yards below, at the footbridge. The discharge at the latter point was about 11,500 second-feet. Between this point and the northern limit of the rainfall two large drainages, Graveyard 
Wash and Copper Hill Wash, flow into Pinal Creek. No measurements were taken on the former, because it added very little to the flood water, and all the high-water marks were made a couple of weeks after the big flood, at a time when the wash was discharging four or five times as much as at the time of the flood. Copper Hill Wash was measured and the discharge found to be about 3,000 second-feet. This, added to the last above-mentioned discharge of the creek, makes 14,500 second-feet, which checks pretty well with the computed discharge at the third cross section. This was taken at a point about a hundred yards above the Government warehouse, and at about the limit of the rainfall. The above discharge data are given in the tabulation below:

Data on discharge of Pinal Creek and Copper Hill Wash, Globe, Ariz., August $1 \%, 190 \%$.

\begin{tabular}{|c|c|c|c|c|c|c|c|}
\hline Locality. & $\begin{array}{c}\text { Area, } \\
\text { cross } \\
\text { section. }\end{array}$ & $\begin{array}{l}\text { Wetted } \\
\text { perime- } \\
\text { ter. }\end{array}$ & $\begin{array}{l}\mathrm{Hy-} \\
\text { draulic } \\
\text { radius. }\end{array}$ & $n$. & Slope. & $\begin{array}{l}\text { Coeffi- } \\
\text { cient, } \\
\text { C. }\end{array}$ & $\begin{array}{c}\text { Dis- } \\
\text { charge. }\end{array}$ \\
\hline Pinal Creek: & Sq. feet. & Feet. & & & & & Sec.feet. \\
\hline Kinney's barn ........ & 800 & 200 & 4.0 & 0.025 & 0.008 & 76 & 10,900 \\
\hline Footbridge, Broad st. - & 610 & 90 & 6.8 & .025 & .008 & 82 & 11,500 \\
\hline $\begin{array}{l}\text { Copper Hill Wash: } \\
\text { About } \frac{1}{4} \text { mile from } \\
\text { mouth }\end{array}$ & 105 & 28 & 3.8 & .025 & .042 & 76 & 3,200 \\
\hline $\begin{array}{l}\text { United States ware- } \\
\text { house }\end{array}$ & 963 & 240 & 4.0 & .025 & .008 & 76 & 13,200 \\
\hline
\end{tabular}

The average duration of the high waters of the flood, as given by a number of observers, was about forty to fifty minutes. Estimating that the discharge was half the maximum for an hour longer and one-fourth the maximum for two hours more, the total quantity of water discharged is as follows:

45 minutes, at 14,000 cubic feet per second

Cubic feet. 60 minutes, at 7,000 cubic feet per second $37,800,000$

120 minutes, at 3,500 cubic feet per second $25,200,000$ $25,200,000$

Total

$88,200,000$

If this amount of water were distributed evenly over 25 square miles the depth would be 1.52 inches. This, of course, does not necessarily disagree with the 2 inches observed rainfall at Globe, since the area covered by the rain is more or less estimated, and it is reasonable to suppose that over part of this area the fall was much less.

Cross sections were also measured about 15 miles below Globe, at 
Wheatfields, where the computed discharge averaged about 5,000 second-feet. I was unable to determine how long the flow continued. Mr. Devore, who lives at Wheatfields, stated that the water began to come down about 8 o'clock and that the water was nearly normal next morning. Estimating the average flow at one-half the computed discharge, and its continuance at eight hours, gives $72,000,000$ cubic feet as the total quantity of water. This does not greatly disagree with the Globe observations.

The principal damage caused by the flood was to the property of the Gila Valley, Globe and Northern Railway. The stock yards and a number of cottages occupied by the railway employees were partly washed away. All the bridges and culverts in the lower part of town were either destroyed or badly damaged and long stretches of the roadbed entirely carried away. The loss was about $\$ 5,000$. The balance of the damage was sustained principally by the merchants on lower Broad street. Several buildings were lifted from their foundations and carried across the street. The goods in these buildings were all destroyed. In many other buildings the water stood 18 inches deep, destroying or damaging much of the contents. The total losses, including that of the railroad, were about $\$ 18,000$.

A most distressing feature of the flood was the great loss of life. Six persons were drowned in a few minutes. The first one was probably asleep in his cabin on the low ground when the wall of water came down and carried the building away. The other five persons were in the Mitchell boarding house. When the flood set in there were eight persons in the house, two of whom made their escape, and a third, son of the proprietor, went to secure ropes with which to rescue the others, three of whom were women, one a cripple. Before he could return the house and its occupants had been swept away.

I am indebted to Mr. Jos. H. Hamill, of the Silver Belt; Mr. A. Kinney; Mr. Cottee, of Cottee \& James, electricians, and Mr. M. S. McEniry, of the United States Geological Survey, for the greater part of the information upon which this report is based.

\section{CANADIAN RIVER BASIN FLOOD, NEW MEXICO, OKLA- HOMA, AND INDLAN TERRITORY. $a$}

From September 30 to October 2, 1904, occurred the largest and most destructive flood on record in the upper part of the Canadian River drainage basin. It was caused by a very heavy downpour of rain September 28 to 30 on the headwaters of this river. Although much damage was done along the stream in Oklahoma and Indian Territory the storm causing the flood did not extend beyond the eastern border of New Mexico, as Ute Creek, which drains a narrow

a Prepared mainly from report of Frank S. Dobson and George B. Monk, engineering aids. 


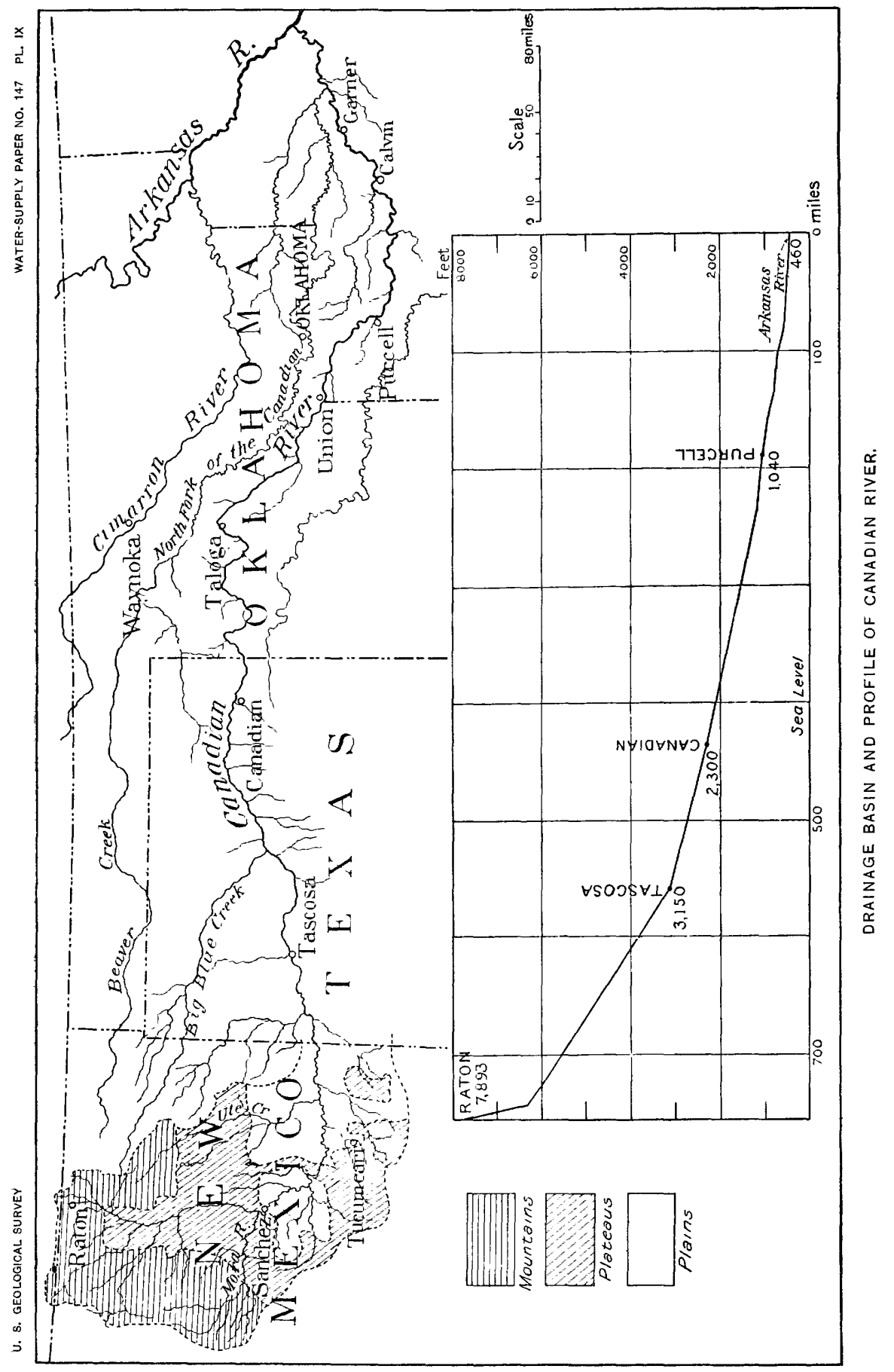


strip extending nearly north and south in the eastern part of New Mexico, did not show any marked rise during the period.

\section{STREAMS AND DRAIN AGE BASIN.}

The Canadian River basin comprises a long, narrow strip of land lying between the Arkansas and Red River drainage, extending northwest from the east boundary of Indian Territory through Okla-

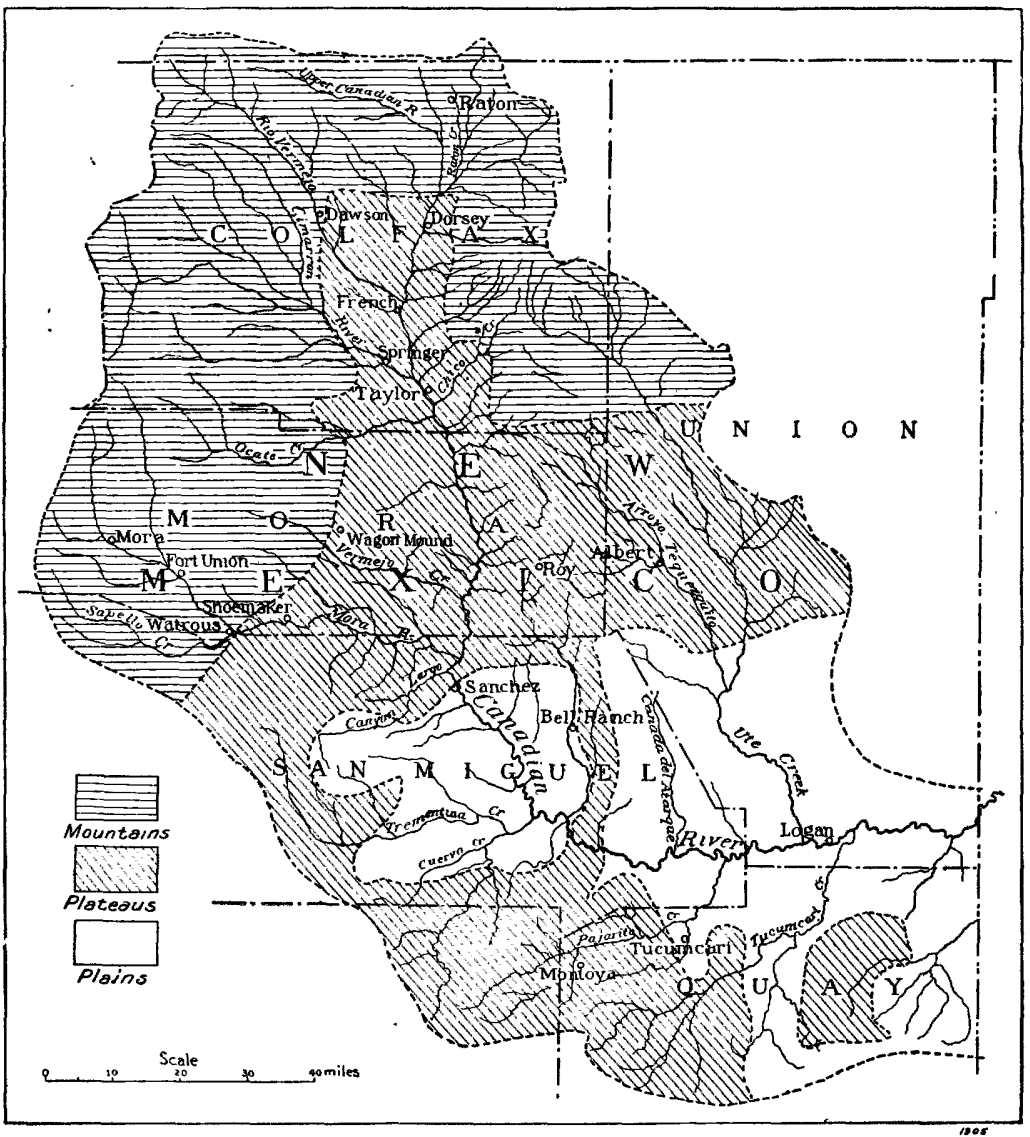

FIG. 12.-Upper portion of drainage basin of Canadian River.

homa, Indian Territory, and northern Texas to the northern part of New Mexico. Its total length is about 875 miles, its greatest width 110 miles. (See Pl. IX.)

The part of the basin in New Mexico where the flood occurred comprises an area of about 12,600 square miles, 3,900 square miles of which is classified as mountainous, 4,600 as plateau, and 4,000 as plains.

The mountainous part ranges in elevation from 8,000 to 12,000 feet, some of the peaks being covered with perpetual snow and having 
little vegetation. The lower mountainous part is covered with wild grasses and some forest growth. The high plateaus are deeply cut by canyons of varying width, with numerous side canyons, from which the smaller streams emerge. These canyons become deeper and wider with the descent until the plains are reached. On these last are scattered high mesas.

The plains are covered with a fine sandy loam, which produces a thick growth of wild grass similar to that on the plateaus. The Canadian cuts through these plains in a canyon about 100 feet deep and from 600 to 800 feet in width.

The chief tributaries of the Canadian in New Mexico are Ute Creek, 96 miles long, with a drainage area of 2,010 square miles; Trementina Creek, 60 miles long, with a drainage area of 670 square miles; Pajarito Creek, 42 miles long, with a drainage area of 570 square miles; Ocate Creek, 72 miles long, with a drainage area of 560 square miles; and Cimarron River, 45 miles long, with a drainage area of 1,050 square miles. The following table shows the slope of the river: ${ }^{a}$

Profile of Canadian River, New Mexico.

\begin{tabular}{|c|c|c|c|}
\hline Locality. & $\begin{array}{c}\text { Distance } \\
\text { from mouth } \\
\text { in miles. }\end{array}$ & $\begin{array}{l}\text { Height } \\
\text { above sea } \\
\text { in feet. }\end{array}$ & $\begin{array}{l}\text { Fall per } \\
\text { mile in feet. }\end{array}$ \\
\hline \multirow[t]{6}{*}{ Mouth } & 0 & 460 & $\ldots$ \\
\hline & 22 & 500 & 1.8 \\
\hline & 82 & 600 & 1.7 \\
\hline & 104 & 700 & 4.5 \\
\hline & 134 & 800 & 3.3 \\
\hline & 152 & 900 & 5.6 \\
\hline Near Purcell & 190 & 1,040 & 3.7 \\
\hline $\begin{array}{l}\text { Chicago, Rock Island and Pacific Railway cross- } \\
\text { ing }\end{array}$ & 240 & 1,200 & 3.2 \\
\hline Canadian ...... & 435 & 2,300 & 5.6 \\
\hline \multirow[t]{3}{*}{ Tascosa } & 550 & 3,150 & 7.4 \\
\hline & 727 & 5,972 & 15.9 \\
\hline & 745 & 6,292 & 17.8 \\
\hline Raton Pass, head . . & 758 & 7,893 & 123.2 \\
\hline
\end{tabular}

The location of the above mentioned tributaries is shown in fig. 12, and the profile of the river in Pl. IX (p. 120). The only other tributary of the Canadian of importance is North Fork, which enters the main river about 35 miles from its mouth.

\footnotetext{
a Gannett, Henry, Profiles of rivers : Water-Sup. and Irr. Paper No. 44 , U. S. Geol. Survey, 1901, p. 66.
} 
The Canadian and its tributaries have a steep slope and a rapid flow. The floods usually occur in spring and are due to the melting snow. They rise and fall slowly and remain at nearly maximum stage for several days. Occasionally, as in the instance under discussion, they are due to rain and are of short duration, rising and falling very rapidly. The great velocity of the river, however, causes these floods to be very destructive.

\section{PRECIPITATION.}

From September 26 to 30 the precipitation over the greater portion of the drainage basin of the Canadian in New Mexico varied from 5 to 7 inches, as shown by the following table, prepared from the United States Monthly Weather Review:

Precipitation in New Mexico, September 26-30, 1904.

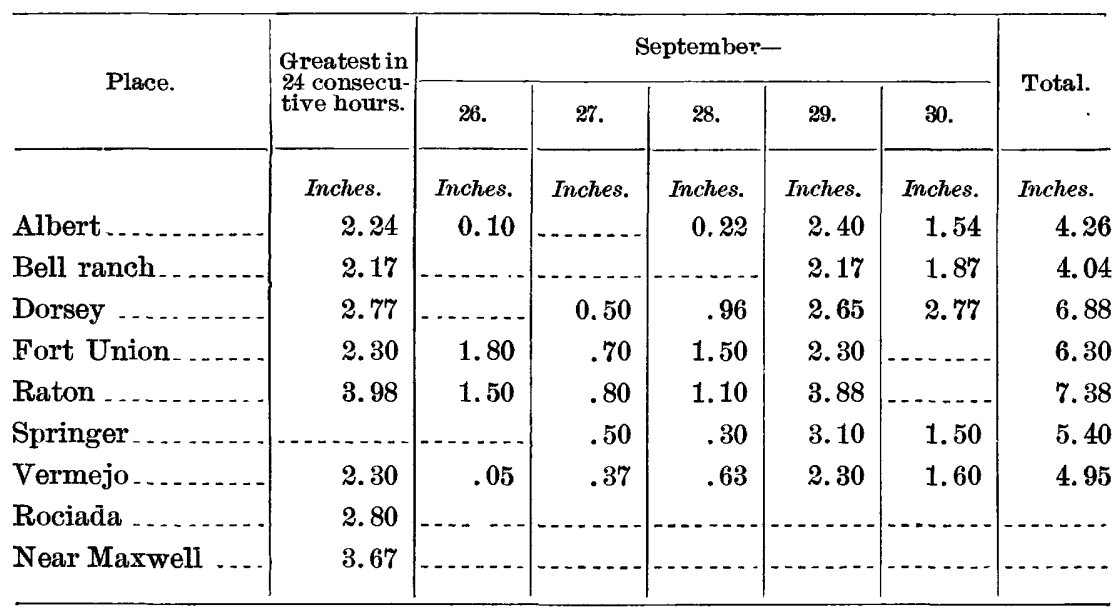

The total precipitation and excess for the month of September, 1904, at places in this drainage basin is shown in the following table:

Precipitation in New Mexico, September, 1904.

\begin{tabular}{|c|c|c|c|}
\hline Place. & $\begin{array}{l}\text { Number } \\
\text { years rec- } \\
\text { ord. }\end{array}$ & $\begin{array}{l}\text { Precipita- } \\
\text { tion. }\end{array}$ & Excess. \\
\hline Albert & 13 & $\begin{array}{l}\text { Inches. } \\
\quad 6.00\end{array}$ & $\begin{array}{l}\text { Inches. } \\
\quad 4.48\end{array}$ \\
\hline Bell ranch. . . . . . . . & 5 & 4.04 & 2.75 \\
\hline Dorsey . . . . . . . & 2 & 7.11 & 2.78 \\
\hline Fort Union . . . . & 43 & 6.84 & 4.77 \\
\hline Raton ....... & 10 & 7.38 & 6.49 \\
\hline Rociada ... & & 8.81 & 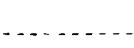 \\
\hline Vermejo . ... . & & 5.39 & \\
\hline W. S. ranch, near Maxwell $\ldots \ldots \ldots \ldots$ & $\ldots \ldots$ & 7.65 & - . . . . \\
\hline
\end{tabular}


This excess of monthly rainfall varied from 2.75 to about 6.5 inches in depth; the greatest precipitation in twenty-four consecutive hours was about 4 inches. Such a downpour of rain on a basin of steep, nonabsorbent surface with little or no storage resulted in a sudden and very large, though local, flood.

\section{FLOOD ON CANADIAN RIVER.}

The gage at the gaging station at Logan was destroyed on October 2,1904 . The mean daily gage readings to the time when the gage was washed away are as follows:

Gage height, in feet, of Canadian River at Logan, N. Mex., September 26 to October 1, 1904.

September 26

0.80

September 27

2. 35

September 28

4. 25

September 29

7. 50

September 30

October 1

This record shows a rise of over 29 feet above low water at Logan. How much higher the river rose after the gage was destroyed the observations do not show.

The cross sections of the flood plain and slope of the river bed were measured at places on the river and its principal tributaries, and the discharge computed by Kutter's formula: $\mathrm{Q}=\mathrm{FC} \sqrt{R S}$, using a coefficient of roughness $n=0.035$. The results are given in the following table:

Data of Canadian River basin flood, 1904.

\begin{tabular}{|c|c|c|c|}
\hline Stream. & Place. & $\begin{array}{l}\text { Discharge } \\
\text { in second- } \\
\text { feet. }\end{array}$ & $\begin{array}{l}\text { Duration of } \\
\text { high stage } \\
\text { in hours. }\end{array}$ \\
\hline Canadian & Logan .. & 140,555 & 12 \\
\hline Do . . & Taylor - & 91,140 & 7 \\
\hline Do _ - & French & 156,000 & .5 \\
\hline Mora & Watrous & 76,000 & .5 \\
\hline Sapello. . & Mouth & 62,900 & .5 \\
\hline
\end{tabular}

Mr. W. G. Russell measured the cross section and slope of bed of the Canadian a short distance below the railway bridge at Logan on October 27, 1904, and found the cross-section area to be about 13,500 square feet, the mean velocity 11.05 feet, the maximum discharge 149,396 cubic feet per second, and the maximum stage above low water 31.3 feet.

Mr. D. P. Richards, a physician at Union City, Okla., states that on October 2, about 11.30 a. m., there was a sudden rise of about 
4 feet in the Canadian. This was followed by a continued rapid rise until about 12.30 p. $`$ m. October 3 , when the river reached its maxi-, mum stage. It remained nearly stationary for about nine hours. and then began to subside. At 1 o'clock on the 4th it was again within its banks.

The following table gives the gage height on Canadian River at Calvin, Ind. T., Cimarron River at Waynoka, Okla., and Beaver Creek at Beaver, Okla., during the flood period:

Gage height, in feet, in Canadian River basin, September 29 to October 8, 1904.

\begin{tabular}{|c|c|c|c|}
\hline Date. & $\begin{array}{c}\text { Canadian } \\
\text { River at } \\
\text { Calvin, } \\
\text { Ind.T. }\end{array}$ & $\begin{array}{c}\text { Cimarron } \\
\text { River at } \\
\text { Waynoka, } \\
\text { Okla. }\end{array}$ & $\begin{array}{l}\text { Beaver } \\
\text { Creek at } \\
\text { Beaver, } \\
\text { Okla. }\end{array}$ \\
\hline September 29 & $\ldots$ & 1 & 0.30 \\
\hline September 30 & 0.2 & 4.50 & .30 \\
\hline October 1 & .1 & 2.50 & .70 \\
\hline October 2 & .1 & 2 & 2.60 \\
\hline October $3 \ldots$ & .0 & 2 & 3.15 \\
\hline October 4 & 9.0 & 2 & 2 \\
\hline October 5 & 4.2 & 4.50 & 1.70 \\
\hline October $6 \ldots$ & 2.0 & 3 & 1.30 \\
\hline October $7 \ldots$ & 1.2 & 1.50 & 1.15 \\
\hline October 8 & 1.0 & 2 & $\ldots-$ \\
\hline
\end{tabular}

There are no available records of the flood of 1885 , but old settlers say it was greater than any for many years prior to that date. An estimate of the discharge of the Canadian at Logan during it has been made by Mr. F. Dobson. From cross sections and slope of bed of stream, using Kutter's formula, the maximum discharge is placed at 70,000 cubic feet per second for about one hour. The estimated maximum discharge October 2, 1904, was 140,555 second-feet, or about double that of the flood of 1885 .

FLOOD ON UTE CREEK.

The gage height at the gaging station on Ute Creek during the flood is given in the following table:

Gage height, in feet, on Cte Creek, September 26 to October $3,1904$.

September $\mathbf{2 6}$

September 27

.20

September 28

September , 29

September 30

October 1 
Although the watershed of this creek is part of the drainage basin of Canadian River, and is only a short distance from it, the flood on it was small, the rise being less than 5 feet above low water, while the rise at Logan on the Canadian was more than 30 feet. Neither North Fork of Canadian River nor Washita River, which flows parallel to the Canadian at Union and not a great distance from it, showed any signs of flood. The local character of the storm is evident.

FLOOD ON SAPELLO RIVER.

The gage at the gaging station on Sapello River, near Los Alamos, was washed out by the flood, and the bank to which it was attached was eroded to a distance of 40 feet back from the river. The river at this place rose above the top of the posts supporting the cable from which the discharge measurements were made.

The river began to rise early in the evening of September 29 and by midnight had reached the maximum stage. By 2 a. m. on September 30 it had receded about 2 feet. This stage was maintained for about forty-eight hours, when it gradually declined until October 7, at which time the discharge was about 150 second-feet. Heavy rains on October 8 again raised the river 2 feet, a height which was maintained for about twenty-four hours. From that time it decreased, and on October 12 the discharge was found by measurement to be 136 second-feet. The ordinary high-water width of the channel at the station is 115 feet, but the width at the highest stage was about 490 feet.

The maximum discharge at the gaging station was computed by Mr. Monk from Kutter's formula. The slope of the stream being 0.0004 foot per foot, the area 3,093 square feet, and the wetted perimeter 501 feet, and the coefficient of roughness being put at 0.040 , the maximum rate of discharge was found to be 8,104 second-feet, and the total discharge from September 29 to October 10 , inclusive, was found to be 67,370 acre-feet. As the drainage area above the gaging station is 221 square miles, this would mean a depth of about 5.71 inches over the entire area, and a run-off for the period from September 29 to October 10, inclusive, of 12.81 second-feet per square mile.

Several small irrigating dams about 7 miles above Los Alamos were washed out by the flood, but the volume of water liberated by their failure was not sufficiently large to produce any marked increase in the flood wave. Very little damage occurred in the immediate vicinity of Los Alamos, as the buildings and fields are high above the river and all crops were stacked above the high-water line. Manuelitas River, which adjoins the Sapello at the town of Sapello, 
"as out of its banks from 8 p. m. on September 29 until noon of the sollowing day. The town of Rociada, on the headwaters of this stream, was completely isolated for several days by the destruction of the road and telegraph wires.

\section{FLOOD ON RIO MORA.}

The gage .at the highway bridge over Mora River at Weber was swept away by the flood, also the bridge itself, the observer's house, the post-office, and the store located near by. On September 29 the "iver began to rise early in the evening, reaching its maximum height of 12 feet about 10 p. m. By 7 a. m. on September 30 the water had fallen 6 feet. It then gradually dropped for five days to a stage such that the discharge was 200 second-feet. It was 3 feet higher on Tctober 7 and 8 for about thirty hours, and then gradually declined 'mtil October 12, when a gaging gave a discharge of 196 second-feet. An estimate of the maxinum discharge at this place was made by Mr. Monk, using Kutter's formula, and found to be 27,724 secondfeet. The discharge for a stage 6 feet lower than the maximum was about 7,335 second-feet, and a stage 3 feet below the maximum gave a discharge of 18,927 second-feet. With these measurements of discharge and the fluctuations in stage, the total discharge from Sep+ember 29 to October 10, inclusive, was found to be 173,249 acre-feet, the drainage area above the point of measurement being 422 square miles. This total volume corresponds to a depth of 7.69 inches over the drainage area and a run-off for the flood period of 17.25 secondfeet per square mile. The damage done by the flood in the vicinity of Weber was estimated to be about $\$ 5,000$.

Rio Cebolla and numerous small arroyos contributed a considerable amount of water to the river below Weber, the Cebolla alone discharging at maximum stage at the rate of about 600 cubic feet per second. Perhaps the worst devastation occurred at Watrous, the junction of Sapello and Mora rivers. Miles of the Santa Fe Railway tracks were washed out; houses, crops, fences, and bridges were swept away, and eight lives were lost in the town.

Excessive damage was caused by the flood in the entire Mora Valley. Commencing at the town of Mora, in the upper end of the valley, where the streets were submerged from 4 to 10 feet deep, about 30 houses were washed out and nearly 300 people rendered homeless. It is estimated that about half the crop in this vicinity was lost.

At La Cueva, 5 miles below Mora, the river was above the wagon bridge on September 27 , and continued to rise until midnight of September 29, the maximum stage lasting about twelve hours. It remained out of its banks until October 5 , when a decrease was appar- 
ent until October 9, when the rains caused it to rise 2 feet. The channel during normal flow is about 32 feet wide, but the distance between the water lines during the flood was about 660 feet. A measurement of the discharge was made at this place by Mr. Monk, using Kutter's formula, and found to be 22,213 second-feet. The total discharge from September 29 to October 10, inclusive, was 161,849 acrefeet. The drainage area being 159 square miles, this volume corre-. sponds to a depth of 9.305 inches over the whole drainage basin. The estimated run-off per square mile for the flood period of twelve days was 20.85 second-feet.

A large amount of damage was done in this vicinity, especially to crops and orchards belonging to the La Cueva Land and Cattle Company. About 500 yards above La Cueva the irrigating ditch, together with the country road to Mora, were washed out for a distance of 20 yards.

Turquillo Valley, a very productive section 8 miles north of the town of Mora, suffered greatly from the flood resulting from a four days' downpour. The waters from Canyon Carro and other minor arroyos originating in the adjacent hills swept through it, destroying the crops. In places the stream was over half a mile wide, and at one point near the upper end a lake of about 500 acres was formed, which will remain for some time, as it has no outlet.

OBSTRUCTION OF STREAMS.

The flood height at certain points was increased by structures across the streams. At French the Santa Fe Railway runs along the right bank of the river on a roadbed 12 feet above the river, while the El Paso and Northeastern Railway crosses it with approaches that restrict the stream to half its natural width. These obstructions, acting as a dam, backed the water over the Santa Fe tracks and depot, forming a lake one-fourth of a mile wide. At Springer the Santa Fe Railway crosses the Canadian on a bridge 170 feet wide hetween abutments and 17 feet above low water, the remainder of the channel being filled with the bridge approaches. Three miles below Watrous the Santa Fe Railway crosses Rio Mora at an angle, with long, high, filled approaches, the low-water channel only being bridged. At these three places the embankment caused backwater and finally gave way, after which the flood rapidly subsided.

DAMAGE DONE BY FLOOD.

It is impossible to give an accurate estimate of the damage done by this flood, and only a few of the larger losses will be mentioned. 
Four miles of track and three bridges were destroyed on the Santa Fe Railway between Watrous and Shoemaker; the Rock Island Railway bridge at Logan, costing $\$ 60,000$, was destroyed; the loss on the El Paso and Northeastern Railway from Taylor to French is estimated to have been $\$ 50,000$; the loss of orchards, irrigation ditches, and 40 adobe houses at Sanchez, $\$ 50,000$; in Mora River Canyon, between Watrous and Shoemaker, seven persons lost their lives, many houses were wrecked, and farms along the river damaged; the Rock Island Railway bridge at Lawton, consisting of two steel spans and two 60-foot steel-girder approaches, was destroyed, one span being carried downstream 3 miles, another 1 mile, and one of the steel girders, weighing 40 tons, $1 \frac{1}{2}$ miles; more than a mile of track was lifted and swept away; 700 feet of trestle approach to the Frisco Railroad bridge was completely destroyed; and similar damage was done at other places along the stream in Oklahoma.

The following information regarding the damage to railroads has been collected from railway officials of the various roads by $\mathrm{Mr}$. Gerard H. Matthes, district engineer :

The Fort Worth and Denver Railroad lost about 600 feet of pile and trestle bridge across the Canadian near Tascosa, Tex., and had about 1,600 feet more damaged. Traffic was delayed four days. The approximate damage is estimated at $\$ 10,000$.

The Atchison, Topeka and Santa Fe Railway sustained considerable damage at Purcell, Ind. T., where it has a roundhouse and extensive yards. The water during the flood stood from 2.5 to 3 feet deep in the yard and in front of the passenger depot and left a deposit of sand in some places 1 foot deep. Spur tracks were washed off the embankment and side tracks were badly washed out in places. Near Walker, Ind. T., 6 miles north of Purcell, about 3,900 feet of embankment, including both main and passing tracks, were demolished. The steel bridge over Canadian River near Walker was not damaged, but 385 feet of approach was washed out. Two miler farther south about 1,600 feet of embankment and a bridge went out. The main line was closed to traffic from 6 p. m. October 3 to $6 \mathrm{p} . \mathrm{m}$. October 10.

The Missouri, Kansas and Texas Railway escaped with relatively little damage. At the crossing between Eufaula and Canadian, Ind. T., one bridge pier slipped on its base about 3 or 4 inches; the repairs cost $\$ 750$. At the new bridge over the washed-out channel of 1898 about 150 feet of embankment south of the bridge was washed out and the south pier was undermined. On the recently completed line from Atoka to Oklahoma City no damage was done to the bridge at Tyrola, Ind. T., but the south approach was washed away and the

IRR $147-05 \mathrm{M} \longrightarrow 9$ 
station grounds covered with sand. A large part of the line in the river valley was torn up.

The St. Louis and San Francisco Railroad lost 2,740 feet of a total of 3,130 feet of the bridge on the Blackwell, Enid and Southwestern branch near Golden, Okla. The cost of repairs was $\$ 20,000$, and the traffic was suspended from October 2 to 25 . On the line between Chickasha and Oklahoma City 490 feet of trestle approach was destroyed, the steel span remaining intact. The cost of repairs is estimated at $\$ 4,600$. The traffic was suspended from October 3 to 15. At the Canadian River Bridge near Francis, Ind. T., about 140 feet of bridge was destroyed, costing in repairs $\$ 1,475$, the traffic being interrupted from October 4 to 9 .

Considerable damage was done to bridges on the Rock Island system, which crosses Canadian River at four different points. The steel bridge south of Union City, Okla., consisting of one steel through span and two girder spans, was completely carried away, the throngh truss being washed downstream several miles.

\section{PECOS RIVER BASIN FLOOD, NEW MEXICO. $a$}

During the latter part of September and the first part of October, 1904, there occurred upon the drainage basin of Pecos River the heaviest and most destructive flood in its recorded history.

\section{STREAMS AND DRAINAGE BASIN.}

Pecos River rises in the northern part of New Mexico, flows in a southeasterly and southerly direction for about 300 miles through New Mexico, thence for about 250 miles southeasterly through Texas, and empties into the Rio Grande near Langtry, Tex. The principal tributaries, all of which enter from the west, are Rio Peñasco, having a length of about 80 miles and a drainage area of 750 square miles; Rio Felix, having a length of 60 miles and a drainage area of 800 square miles; Rio Hondo, having a length of 90 miles and a drainage area of 1,900 square miles; Salt Creek, having a length of 80 miles and a drainage area of 2,550 square miles; Pintado Creek, having a length of 70 miles and a drainage area of 1,000 square miles; and Rio Gallinas, having a length of 50 miles and a drainage area of 620 square miles. These tributaries and the location of the gaging and precipitation stations are shown in $\mathrm{Pl}$. $\mathbf{X}$. The slope of the river is shown in the following table:

a Based on data obtained by personal observation during the flood and after it had subsided, by W. M. Reed, engineer, F. S. Dobson, engineering aid, and Geo. B. Monk, assistant hydrographer; prepared mainly from report by F. S. Dobson. 
U. S. GEOLOGICAL SURVEY

WATER-SUPPLY PAPER NO. 147 PL. $X$

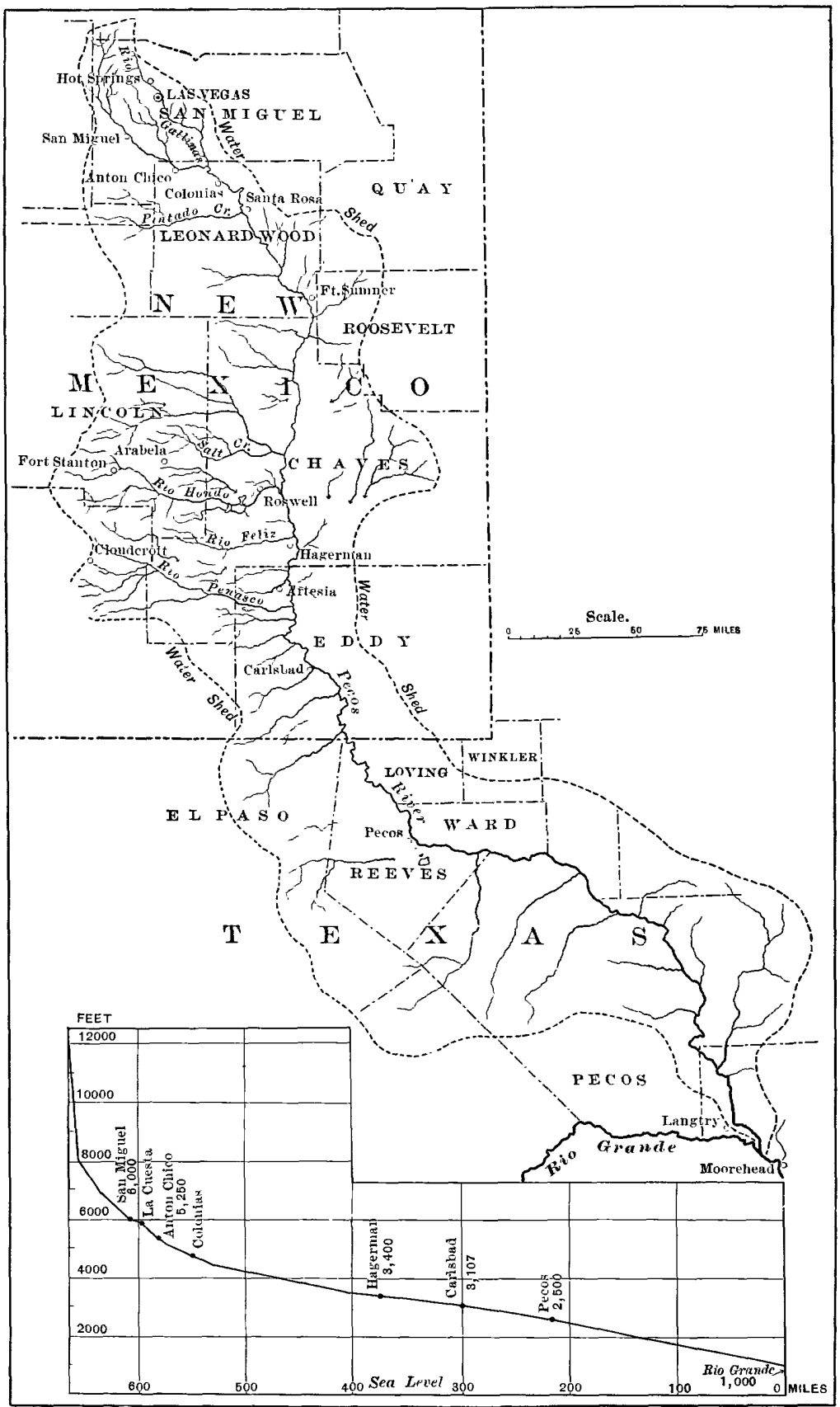

DRAINAGE BASIN AND PROFILE OF PECOS RIVER. 
Profile of Pecos River, New Mexico.a

\begin{tabular}{|c|c|c|c|}
\hline Locality. & $\begin{array}{l}\text { Distance } \\
\text { from mouth } \\
\text { in miles. }\end{array}$ & $\begin{array}{l}\text { Height } \\
\text { above sea } \\
\text { in feet. }\end{array}$ & $\begin{array}{l}\text { Fall per } \\
\text { mile in } \\
\text { feet. }\end{array}$ \\
\hline Mouth .. & 0 & 1,000 & $\ldots$ \\
\hline Pecos $\ldots \ldots$ & 215 & 2,550 & 7.2 \\
\hline Eddy $\ldots \ldots$ & 300 & 3,107 & 6.6 \\
\hline Hagerman & 375 & 3,400 & 3.9 \\
\hline Crossing, Pecos River Railroad . & 405 & 3,500 & 3.3 \\
\hline Latitude $35^{\circ}$. & 530 & 4,600 & 8.8 \\
\hline Las Colonias & 548 & 4,850 & 13.9 \\
\hline \multirow[t]{2}{*}{ La Junta } & 556 & 4,950 & 12.5 \\
\hline & 567 & 5,100 & 13.6 \\
\hline Anton Chico. & 577 & 5,250 & 15.0 \\
\hline La Cuesta ... & 597 & 5,800 & 27.5 \\
\hline \multirow[t]{4}{*}{ San Miguel } & 607 & 6,000 & 20.0 \\
\hline & 622 & 6,500 & .33 .3 \\
\hline & 637 & 7,000 & 33.3 \\
\hline & 657 & 8,000 & 50.0 \\
\hline Head. & 663 & 12,000 & 666.7 \\
\hline
\end{tabular}

a Gannett, Henry. Profiles of rivers: Water-Sup. and Irr. Paper No. 44, U. S. Geol. Survey, 1901 , p. 37 .

About 20,000 square miles of the drainage basin of this stream is in New Mexico, the greater portion being rolling sand hills, easily cultivated, and very productive when irrigated. Along the eastern, western, and northern edges of the basin are mountains, having peaks covered with snow all the year round. Above Santa Rosa and below Roswell the valley is well developed, but between these cities it is sparsely settled. South of Roswell there is an area of about 350,000 acres that will probably be eventually irrigated from artesian wells.

The Pecos, as can be seen from the profile above, has a very steep slope; its tributary streams also have steep slopes; consequently, the flow of all is very rapid and destructive during time of flood.

\section{PRECIPITATION.}

The precipitation for September and October, 1904, measured by the United States Weather Bureau at six places in this drainage basin, was as follows: 
Precipitation in Pecos River drainage basin, September and October, 1904.

\begin{tabular}{|c|c|c|c|c|c|}
\hline \multirow{2}{*}{ Place. } & \multirow{2}{*}{$\begin{array}{l}\text { Length } \\
\text { of } \\
\text { record. }\end{array}$} & \multicolumn{2}{|c|}{ September. } & \multicolumn{2}{|c|}{ October. } \\
\hline & & $\begin{array}{l}\text { Total pre- } \\
\text { cipitation. }\end{array}$ & Excess. & $\begin{array}{l}\text { Total pre- } \\
\text { cipitation. }\end{array}$ & Excess. \\
\hline Arabela. & $\begin{array}{r}\text { Years. } \\
2\end{array}$ & $\begin{array}{l}\text { Inches. } \\
9.95\end{array}$ & Inches. & $\begin{array}{l}\text { Inches. } \\
5.90\end{array}$ & Inches. \\
\hline Carlsbad . & 9 & 4.55 & +3.45 & 1.71 & +0.82 \\
\hline Cloudcroft .... & 1 & 6.16 & $\ldots$ & 4.37 & $\ldots$ \\
\hline Fort Stanton & 3 & 6.06 & $\ldots$ & 2.68 & $\cdots$ \\
\hline Las Vegas & 17 & 6.07 & +3.90 & 1.08 & .00 \\
\hline Roswell... & 11 & 5.10 & +3.06 & 2.67 & +1.06 \\
\hline
\end{tabular}

The precipitation during September varied from about 4.5 inches to 10 inches, which was. 3 or more inches greater than the normal rainfall for this month. The precipitation for October was less than that for September, but was somewhat above the normal for October.

The following table gives the daily precipitation for the periods September 26 to 30 and October 5 to $8,190 t$, and, taken in connection with the previous table, shows that more than half the September and October precipitation fell during these periods. The precipitation for twenty-four consecutive hours during these storms at five of these places was, as seen from the table, 2.7 inches or more.

As a result of these two periods of excessive precipitation, there was one large flood on this stream and a second somewhat smaller. flood on some parts of it.

Daily precipitation in the Pecos River drainage basin September 26 to 30 and October 5 to 8, 1994, also the greatest precipitation in twenty-four consecutive hours.

\begin{tabular}{|c|c|c|c|c|c|c|c|}
\hline \multirow{2}{*}{ Station. } & \multirow{2}{*}{$\begin{array}{c}\text { Precipita- } \\
\text { tion in } 24 \\
\text { consecutive } \\
\text { hours. }\end{array}$} & \multicolumn{6}{|c|}{ September- } \\
\hline & & 26. & 27. & 28. & 29. & 30 . & Total. \\
\hline Arabela & 2.70 & $\mathbf{T}$. & 0.08 & 0.51 & 2.70 & 1.88 & 5.17 \\
\hline Carlsbad .... & 2.69 & . & - & $\ldots$. & .95 & - & .95 \\
\hline Cloudcroft... & 2.80 & 0.10 & 2.80 & 1.40 & .90 & (n. & 5. 20 \\
\hline Fort Stanton & 2.86 & $\mathrm{~T}$. & $\cdots$ & 1.00 & 2.00 & 2.86 & 5.86 \\
\hline Las Vegas . & 2.87 & .05 & .10 & .26 & 2.87 & 1.77 & 5.05 \\
\hline Roswell ... & 1.80 & & & .42 & .75 & & 1. 17 \\
\hline
\end{tabular}


Daily precipitation in the Pecos River drainage basin, etc-Continued.

\begin{tabular}{|c|c|c|c|c|c|c|}
\hline \multirow{2}{*}{ Station. } & \multirow{2}{*}{$\begin{array}{c}\text { Precipita- } \\
\text { tion in } 24 \\
\text { consecutive } \\
\text { hours. }\end{array}$} & \multicolumn{5}{|c|}{ October- } \\
\hline & & 5. & 6. & 7. & 8. & Total. \\
\hline Arabela_ & 2.50 & & .... & 1.13 & 2.50 & 3.63 \\
\hline Carlsbad.. & .38 & 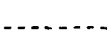 & 0.17 & .09 & .31 & .57 \\
\hline Cloudcroft . . & 2.08 & 0.20 & .20 & 1.00 & 2.08 & 3.48 \\
\hline Fort Stanton & 1.30 & $\mathbf{T}$. & ..... & 1.30 & 1.08 & 2.38 \\
\hline Las Vegas & .76 & $\mathbf{T}$. & .04 & .76 & $\ldots$ & .80 \\
\hline Roswell. & .80 & & T. & .80 & .60 & 1.40 \\
\hline
\end{tabular}

FLOOD ON THE PECOS.

Floods are not uncommon on the Pecos. They usually result from melting of snow, but occasionally, as in the present case, from heavy rains. There are five gaging stations on the main portion of this stream and some on its tributaries. The stations on the main stream are at Santa Rosa, Roswell, and Carlsbad, in New Mexico, and Pecos and Moorehead, in Texas. From the gage-height records obtained at these stations, the magnitude, duration, and to some extent the progress of the flood down the river can be seen. Unfortunately, however, the flood destroyed some of the gages, and also changed the channel of the river to such an extent at some of them that the records are partly wanting or very poor.

Mean daily gage height at gaging stations along Pecos River, September 27 to October $2 \% .1904$.

\begin{tabular}{|c|c|c|c|c|c|}
\hline Date. & $\begin{array}{c}\text { Santa Rosa, } \\
\text { N. Mex. }\end{array}$ & $\begin{array}{l}\text { Roswell, } \\
\text { N. Mex. }\end{array}$ & $\begin{array}{l}\text { Carlsbad, } \\
\text { N. Mex. }\end{array}$ & Pecos, Tex. & $\begin{array}{c}\text { Moorehead, } \\
\text { Tex. }\end{array}$ \\
\hline September 27 & 1.40 & 3.50 & & & \\
\hline September 28 & 4.00 & 3.65 & & & \\
\hline September 29 & 13.00 & 5.50 & & & \\
\hline September 30 & $a 23.00$ & 16.45 & 0.83 & & \\
\hline October $1: \ldots$ & $a_{6.00}$ & 16.45 & 3.45 & & \\
\hline Octaber 2 & $a 3.00$ & 15.0 & 15.00 & 3.50 & \\
\hline October 3 & a 3.00 & $\cdots$ & $(b)$ & 7.00 & - \\
\hline October 4 & $a 2.00$ & $\ldots$ & & 9.00 & 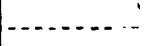 \\
\hline October 5 & $a 2.00$ & 4.0 & & 19.00 & \\
\hline October 6 & $a 2.00$ & 3.9 & & 17.00 & $\ldots$ \\
\hline October $7 \ldots$ & 2.00 & 3.7 & & 15.50 & 1.60 \\
\hline October 8 & 2.00 & - & & 13.00 & 2.10 \\
\hline October $9 \ldots$ & 2.00 & 6.45 & & 13.00 & 2.90 \\
\hline October $10 \ldots$ & 2.00 & 4.45 & & 11.00 & 3.30 \\
\hline
\end{tabular}


Mean daily gage height at gaging stations along Pecos River, 1904-Continued.

\begin{tabular}{|c|c|c|c|c|c|}
\hline Date. & $\begin{array}{l}\text { Santa Rosa, } \\
\text { N.Mex. }\end{array}$ & $\begin{array}{l}\text { Roswell, } \\
\text { N. Mex. }\end{array}$ & $\begin{array}{l}\text { Carlsbad, } \\
\text { N.Mex. }\end{array}$ & Pecos, Tex. & $\begin{array}{c}\text { Moorehead, } \\
\text { Tex. }\end{array}$ \\
\hline October 11 & 3.0 & $5 ., 00$ & 7.60 & 10.50 & 3.30 \\
\hline October 12 & 3.0 & 4.45 & 5.90 & 14.00 & 3.45 \\
\hline October 13 & & & & 13.00 & 3.65 \\
\hline October 14. . & & & & 12.00 & 3.75 \\
\hline October 15 & & & & 9.00 & 4.10 \\
\hline October 16 & & & & 8.40 & 4.30 \\
\hline October 17 & & & & 8.20 & 4.45 \\
\hline October 18 & & & & 8.10 & 4.60 \\
\hline October 19 & & & & 7.80 & 4.75 \\
\hline October 20 . & & & & 7.30 & 4.90 \\
\hline October 21 & & & & 7.00 & 5.00 \\
\hline October 22. & & & & - & 5.05 \\
\hline October 23 & & & & & 5.35 \\
\hline October 24 & & & & & 5. 30 \\
\hline October 25. & & & & & 5.20 \\
\hline October 26 & & & & & 5.05 \\
\hline October 27 & & & & & 4.80 \\
\hline
\end{tabular}

Measurements of flood cross sections and slope of bed were made at places along the Pecos and some of its tributaries, and the maximum discharge computed by Mr. F. S. Dobson by Kutter's formula. The following rates of flow were obtained: Pecos River at Fort Sumner 4.5,150 second-feet, at mouth of Salt Creek 45,350 second-feet, and at Roswell gaging station 55,690 second-feet; Salt Creek above mouth 12,400 second-feet; and Hondo River at gaging station near reservoir 6,330 second-feet. Mr. V. L. Sullivan, chief engineer of the Pecos Irrigation Company, estimated the flow of the Pecos at Lake Macmillan reservoir at the time the water began to pass over the rock spillway at 82,000 cubic feet per second.

The flood at Santa Rosa extended from September 28 to October 2, reaching a maximum on September 30, with a gage height of about 23 feet-that is, about 22 feet above low water. The estimated maximum discharge is 46,498 second-reet. There is little, if any, indication at this place of the second flood plainly seen in the records lower down the river.

Mr. W. G. Russell measured a cross section and the slope of the bed of the Pecos at Santa Rosa, October 26, 1904, and found the crosssection area to be 4,973 square feet, the velocity by Kutter's formula about 9.35 feet, and the maximum discharge 46,498 second-feet. The maximum stage above low water was about 23.4 feet. 


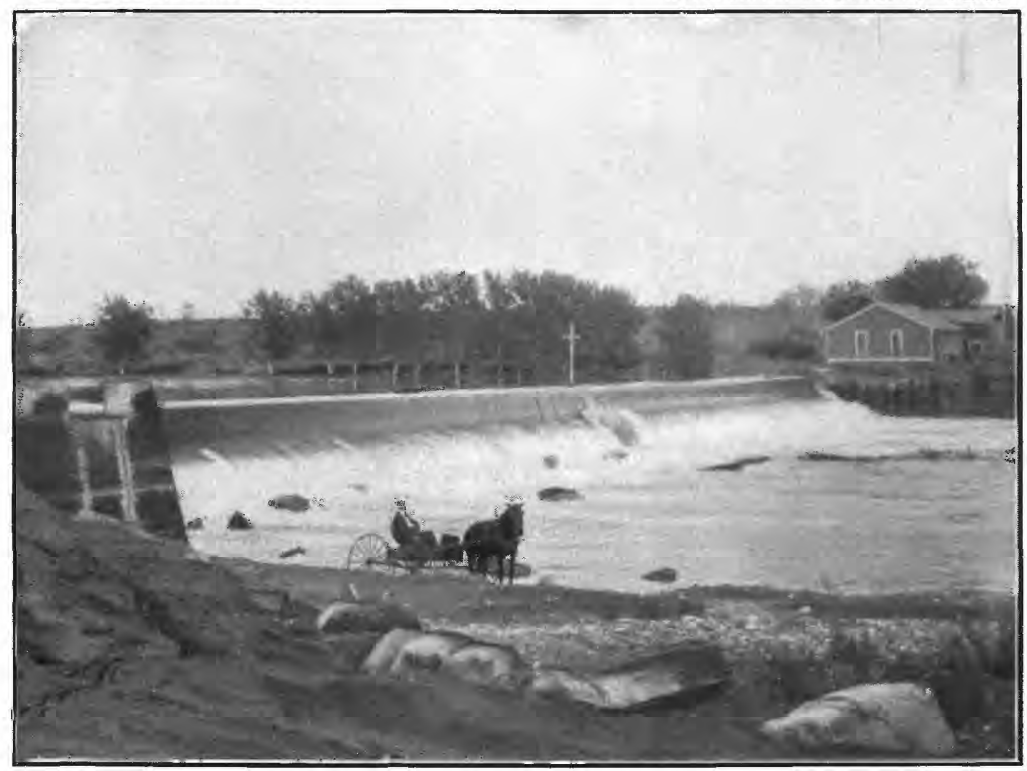

A. DAM ON PECOS River at CARLSBAD, N. MEX., BeFore tHE FLOOD OF OCTOBER, 1904.

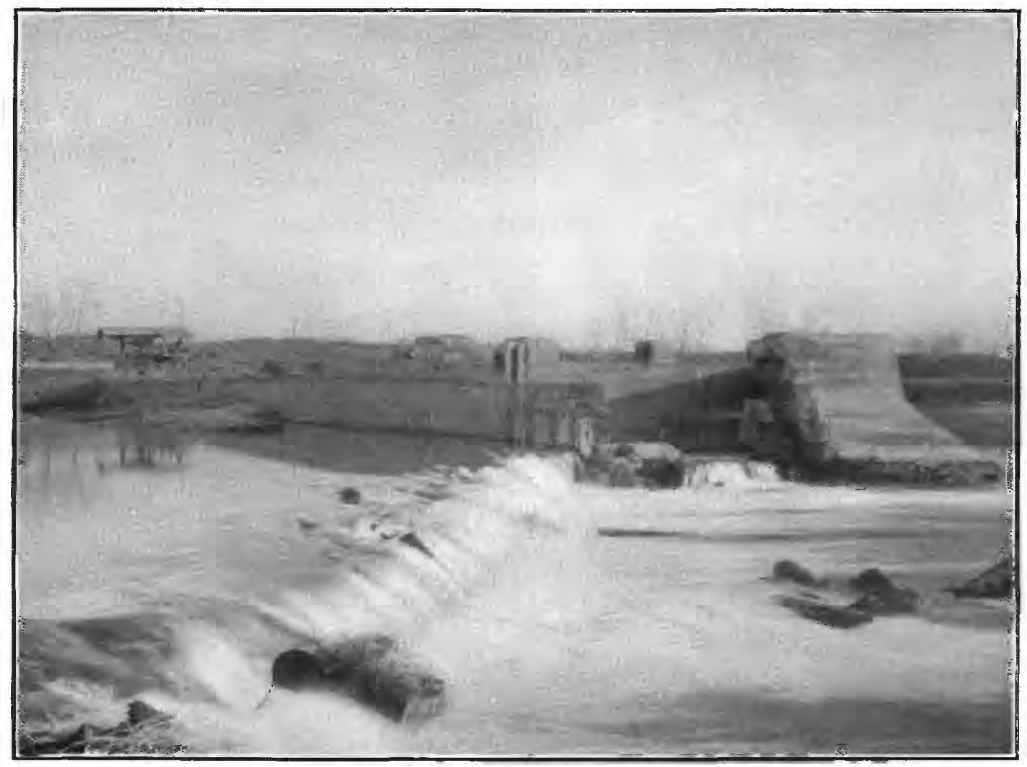

B. DAM AT CARlsbad, N. MEX., after the FloOd OF OCTOBER, 1904. 


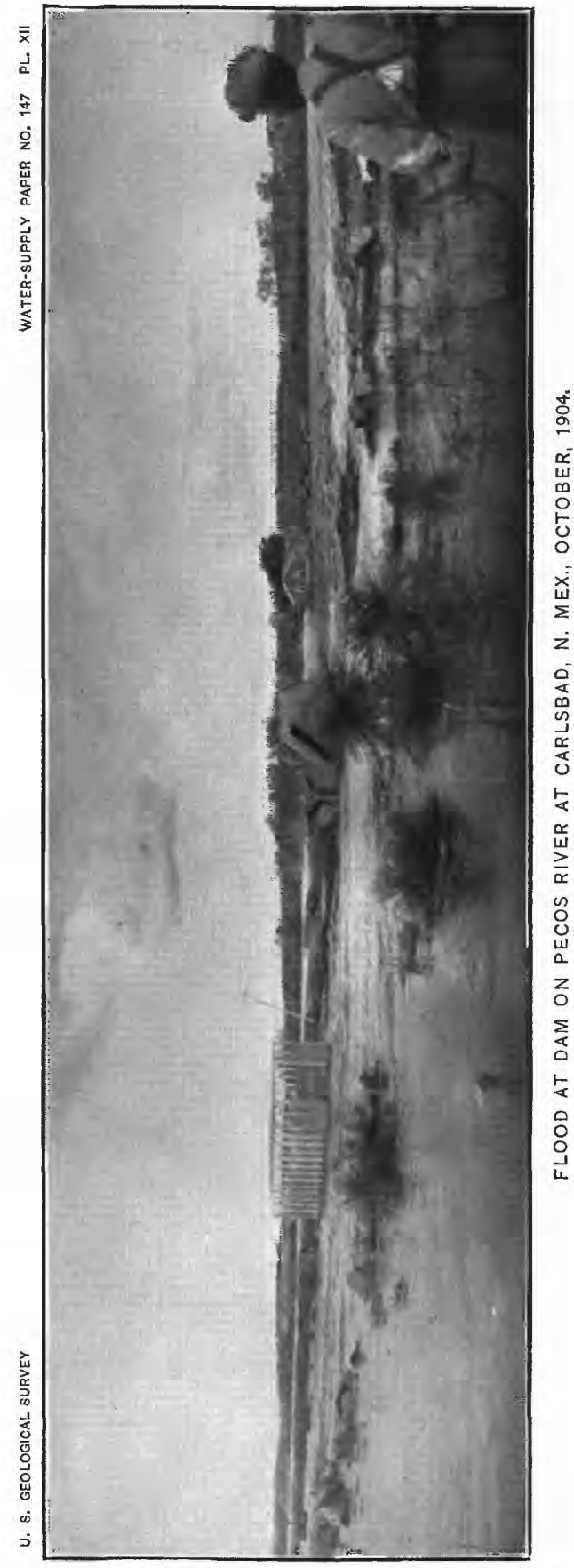


At Roswell the flood began on September 29 and continued until October 4, attaining a maximum on October 1 , with a gage height of more than 17 feet and a discharge of about 55,690 second-feet. The surface fluctuations during this flood of Hondo River, which enters the Pecos near Roswell, are shown on page 139. The stage of the Hondo was a maximum at the gaging station at Hondo reservoir on October 5 at $5 \mathrm{p}$. $\mathrm{m}$.

The flood at Carlsbad, as shown by the gage heights at Lake Macmillan, was at its maximum height $9.40 \mathrm{a}$. m. on October 2. (See Pls. XI, XII.) At Pecos the first flood reached a maximum stage on October 5 and the second on October 12. At Moorehead the maximum stage was not attained until October 23 .

At Lake Macmillan, near Carlsbad, the following fluctuations of the Pecos during the flood were reported by Mr. V. L. Sullivan:

Gage height at Lake Macmillan, near Carlsbad, N. Mex., September 29 to October. 2. 1904

\begin{tabular}{|c|c|c|}
\hline Date. & Time. & $\begin{array}{l}\text { Height in } \\
\text { feet. }\end{array}$ \\
\hline September 29 & 6 a. $\mathrm{m}$ & 18.8 \\
\hline September 29. & $12 \mathrm{~m} \ldots \ldots$ & 18.8 \\
\hline September 29 . & 6 p.m. & 18.8 \\
\hline September 30 & 6 a. $\mathrm{m}$ & 19.0 \\
\hline September 30 & $12 \mathrm{~m}$ & 19.3 \\
\hline September $30 \ldots$ & 6 p. m ... & 19.3 \\
\hline October 1 . - & 6 a. $\mathrm{m} \ldots$ & 21.1 \\
\hline October 1 . & $12 \mathrm{~m} \ldots$ & 21.5 \\
\hline October $1 \ldots$ & 6 p. m $\ldots$ & 22.0 \\
\hline October $2_{-}$ & 1.30 a. $\mathrm{m}$ & 23.0 \\
\hline October $2 \ldots$ & 6.45 a. $\mathrm{m}$ & 27.0 \\
\hline October $2 \ldots$ & 7.30 a. $\mathrm{m}$ & 27.2 \\
\hline October $2 \ldots$ & 8.40 a. $\mathrm{m}$ & 27.5 \\
\hline October 2.... & 9.40 a. $\mathrm{m}$ & 27.9 \\
\hline October 2 & $12.45 \mathrm{p} . \mathrm{m}$ & 27.7 \\
\hline
\end{tabular}

On October 3 Pecos River reached a stage of 7 feet at the United States Geological Survey gage near Pecos, and was slightly rising. ${ }^{a}$ At 10 a. $\mathrm{m}$. on October 4 the stage was increasing at the rate of about 1 foot per hour. At this time four breaks occurred in the Barstow Irrigation Company's levees, designed to protect the west valley lands from flood, at points about $3 \frac{1}{2}$ miles above the flume that carries the canal over Pecos Biver. Other breaks occurred later in the day, and on the morning of October 5 the water had a 
width of from one-half mile to $2 \frac{1}{2}$ miles on each side of the river and extended nearly to the foothills on each side of the valley, with a depth of from 2 to 4 feet. It had a reddish-gray appearance and a comparatively sluggish flow. Fortunately warnings had been given in ample time to permit the removal of stock to places of safety. The river continued to rise, and at 8 a. m. on October 6 reached a stage of 19 feet on the gage near Pecos. The water was above the base of the flume (see Pl. XIII), and its upward pressure, together with the downstream pressure of the water and the drift which collected against the flume, caused it to tear loose at the ends, break in two pieces, and float downstream. One of these parts, about 150 feet long, was afterwards found about $1 \frac{1}{4}$ miles downstream; the other part, also about 150 feet long, floated about 6 miles downstream to the railway bridge, where it was again broken in two and passed on down the stream.

On October 15 the stage at the gage was again 9 feet; thus this flood, which swept through Roswell, N. Mex., in about three days, spread itself out to such an extent as to require about ten days to pass Pecos. On October 19, about two weeks after the beginning of the flood, most of the overflow water had found its way back into the river and passed downstream.

The water left a deposit of reddish clay and fine sand where it was sluggish and coarse sand where it was swift, of a depth generally of from 0.2 to 0.4 foot, but in some places of from 1 to 2 feet: In the west valley about two-thirds of the alfalfa was covered so deeply with silt or was submerged so long that it died. Some cotton, not all, in places was so deeply covered with sand as to be a complete loss. In all, 40 per cent of the cotton was saved, although the lands are generally lower than on the eastern side. Out of a total of 900 acres, about 700 were flooded.

On the east-valley side about a thousand acres of cultivated land was heavily, and as much more lightly, flooded. That in sorghum was badly injured, and from 25 to 50 per cent of the heavily flooded cotton was lost; while few plants were killed, except in little sags, many bolls were soaked until they soured.

At Riverton practically all crops, except on one farm, were lost, much sediment was left in the first mile of the main canal, the headgates were washed out, and all the laterals were destroyed.

Grand Falls escaped any material injury. The crest of the flood had become lower when it reached there, and most of the lands in use are on the second bench.

The following table gives the daily gage height obtained at the United States Geological Surwey station near Pecos, Tex., during this flood: 


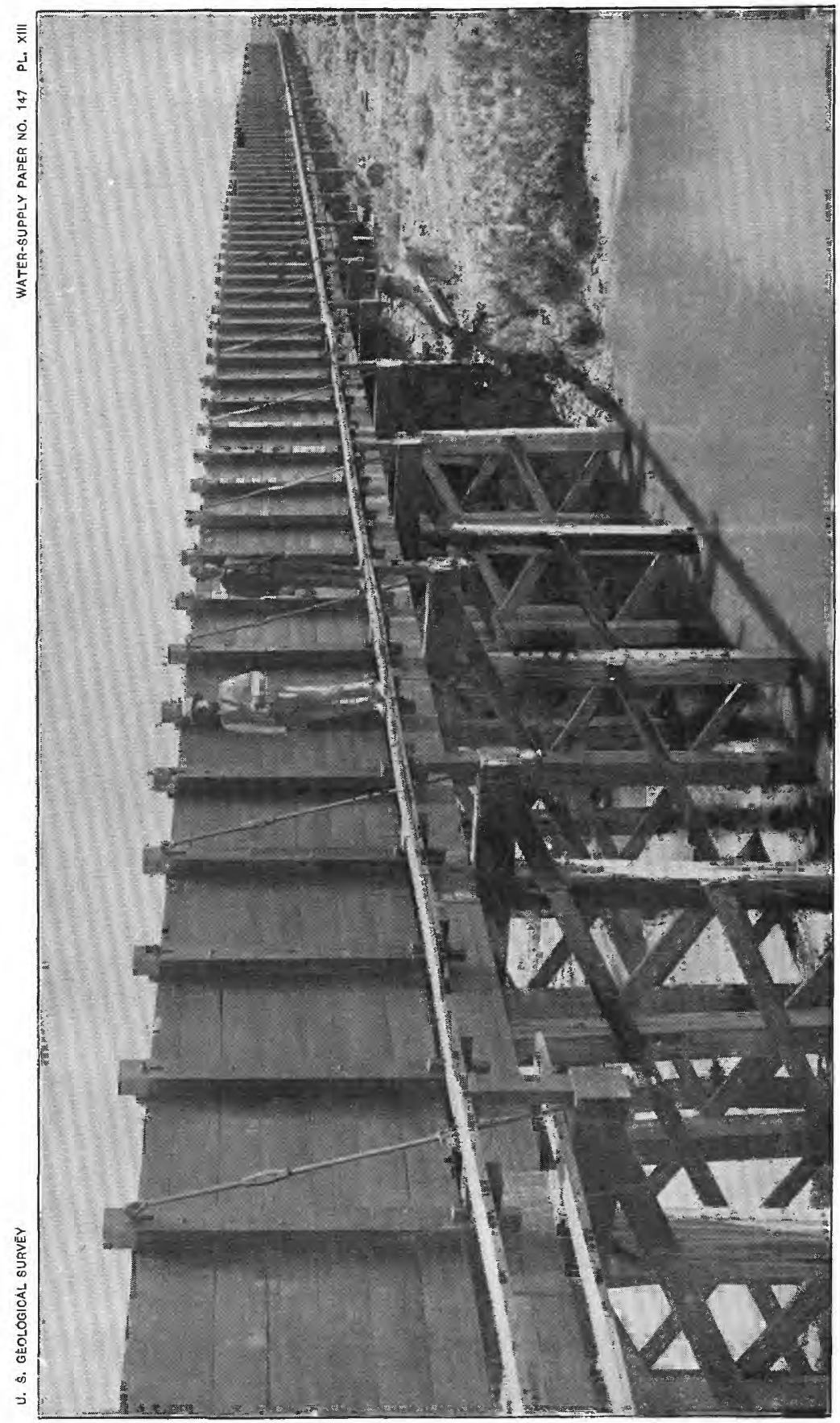

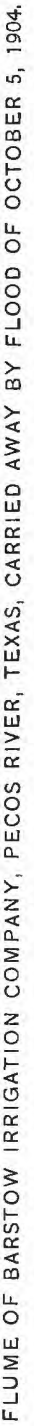


Gage height, in feet, of Pecos Riner near Pecos, Tex., October 2 to 21, 1904.

October 2 - 3.50

October 3 _. 7.00

October 4 _. 9.00

October 5 _. 00

October 6 _

October 7 -

October 8 . 13.00

October 9 - 13.00

October 10 _ 11.00

October 11 _ 10.50

October 12 _.

October 13 _.

October 14

October 15 .

October 16 _._._. 8.40

October 17 ........ 8.20

October 18 ..._. 8.10

October 19 _. 7.80

October 20

October 21 _.

The flood thus reached a maximum stage on October 5 , with a gage height of about 19 feet, or a height above low water of about 18 feet. The gage read 9 feet or more for twelve consecutive days.

The following table gives the daily gage height and corresponding discharge at Moorehead, Tex., near the mouth of the river, during this flood. The river at this place began to rise on October 8, reaching a maximum on October 23. At Santa Rosa the flood lasted from September 28 to October 3-that is, about four days-reaching a maximum above low water of about 22 feet. At Moorehead, 520 miles down the stream from Santa Rosa, it lasted from October 8 to beyond October 27, attaining a maximum height on October 23 of 4 to 5 feet above low water.

Gage height and discharge of Pecos River at Moorehead, Tex., October 7 to $27,1904$.

\begin{tabular}{|c|c|c|c|c|c|}
\hline Date. & $\begin{array}{c}\text { Height } \\
\text { in feet. }\end{array}$ & $\begin{array}{l}\text { Discharge } \\
\text { in second- } \\
\text { feet. }\end{array}$ & Date. & $\begin{array}{l}\text { Height } \\
\text { in feet. }\end{array}$ & $\begin{array}{l}\text { Discharge } \\
\text { in second- } \\
\text { feet. }\end{array}$ \\
\hline October 7 & 1.60 & 590 & October 18 & 4.60 & 3,680 \\
\hline October 8. & 2.10 & $a 700$ & October $19 \ldots$ & 4.75 & 4,040 \\
\hline October 9 & 2.90 & 1,260 & October $20 \ldots$ & 4. 90 & 4,410 \\
\hline October 10. & 3.30 & 1,740 & October 21 & 5.00 & 4,660 \\
\hline October 11 & 3.30 & 1,740 & October 22 & 5.05 & 4,790 \\
\hline October 12 & 3.45 & 1,830 & October 23 & 5.35 & $a 5,577$ \\
\hline October 13 & 3.65 & 2,050 & October 24 & 5. 30 & 5,460 \\
\hline October 14 & 3.75 & $a_{2,095}$ & October 25 & 5.20 & 5,220 \\
\hline October 15 & $4: 10$ & 2,630 & October $26 \ldots$ & 5.05 & 4,880 \\
\hline October $16 \ldots$ & 4.30 & 3,010 & October 27 & 4.80 & 4,360 \\
\hline October $17 \ldots \ldots$ & 4.45 & $a_{3}, \mathbf{3 4 0}$ & & & \\
\hline
\end{tabular}

a Obtained with current meter. 
FLOOD ON GALLINAS RIVER.

During the night of September 29, while the flood was at its height, four timber dams on Gallinas River above Las Vegas and Hot Springs were washed out, liberating about 6 acre-feet of water. The timbers from these dams formed a temporary dam in front of the trestle of the upper bridge at Hot Springs and forced out the bridge about 1 a. m. September 30 . The volume of water, headed by the timber from the dam, took out two more footbridges, the end of the bath house, all the masonry protection wall above the main span bridge at the railway station, and 50 feet of masonry wall below the bridge. Between Hot Springs and Las Vegas, 6 miles down the valley, three railway bridges were washed out and the railway tracks were more or less damaged. At Las Vegas the railway station for the Hot Springs branch, a large frame structure situated on the left of the bank, was completely taken out by the erosion of the bank. An adjoining building, belonging to the Moore Lumber Company, was damaged to a considerable extent and considerable lumber lost.

The greater portion of all the damage at Hot Springs and at Las Vegas was undoubtedly due to the obstruction formed by the temporary wooden dam against the trestle of the bridge at Hot Springs.

The amount of damage sustained by the Agua Pura Company, which owned the timber dams that were destroyed, is estimated to have been from $\$ 5,000$ to $\$ 8,000$; the damage at Hot Springs is estimated to have been about $\$ 10,000$, and to the town of Las Vegas about $\$ 25,000$.

The following are readings of the gage at Hot Springs before it was destroyed by the flood:

Gage height, in feet, at Hot springs, N. Mex., 1904

September 29,7 a. m. 2. 50

September 29, 9 a. $\mathrm{m}$

September 29, $12 \mathrm{~m}$ 3.50

September 29,5 p. m 4. 00

September 29, 9 p. m. 5. 00

September $29,11 \mathrm{p}$. m., the first rush of water came down the stream.

September 30, 12.30 a. m., temporary timber dam formed in front of bridge.

September 30, 1 a. m., the temporary dam in front of bridge was swept away.

The maximum discharge of this stream was computed from Kutter's formula by Mr. Monk, using a cross section of the stream about 200 yards below the gaging station. The slope was found to be 0.0041 feet per foot, area 1,534 second-feet, wetted perimeter 212 feet. With these data and the value of the coefficient of roughness $n=0.05$, the maximum discharge was found to be 11,612 second-feet. This rate of flow continued for about one hour. At $8 \mathrm{a}$. m. on September 30 the river had fallen so that its discharge was about 700 second-feet, and on October 11 its discharge was 135 second-feet. 
The total discharge from September 29 to October 7 , inclusive, which can be considered the flood period of this stream at this place, was found to be 16,572 acre-feet, from a drainage area of 90 square miles. This means an average depth of 3.44 inches over this area, and a run-off per square mile during the nine days of the flood of 10.31 second-feet.

The channel through Las Vegas is very crooked and causes the water to rush from one bank to the other, and as there were no protection walls on either bank considerable erosion took place.

\section{FLOOD ON HONDO RIVER.}

The following table gives the daily gage height and approximate discharge of Hondo River at the reservoir 12 miles southwest of Roswell, N. Mex., and at the gaging station at Roswell. The maxinum discharge is very uncertain as the stream overflowed its banks and a considerable part of the discharge passed around the gaging station.

Gage height and discharge of Hondo River at Roswell and near the reservoir, September 27 to. October $15,1904$.

\begin{tabular}{|c|c|c|c|c|}
\hline \multirow[b]{2}{*}{ Date. } & \multicolumn{2}{|c|}{ Roswell. } & \multicolumn{2}{|c|}{ Reservoịr. } \\
\hline & $\begin{array}{c}\text { Gage height } \\
\text { in feet. }\end{array}$ & $\begin{array}{c}\text { Discharge } \\
\text { in second. } \\
\text { feet. }\end{array}$ & $\begin{array}{l}\text { Gage height } \\
\text { in feet. }\end{array}$ & $\begin{array}{l}\text { Discharge } \\
\text { in second- } \\
\text { feet. }\end{array}$ \\
\hline September 27 & 0.00 & 0.00 & 1.15 & 14 \\
\hline September 28 & 2.25 & .62 & 5.50 & 370 \\
\hline September 29 & 3.60 & 2.24 & 2.30 & 70 \\
\hline September 30 & (a) & $\ldots .$. & 9.60 & 4,400 \\
\hline October 1 & $(a)$ & -- & 10.16 & 6,290 \\
\hline October 2 & 2.35 & 70 & 1.80 & 33 \\
\hline October 3 & 1.65 & 29 & 1.15 & 14 \\
\hline October $4 \ldots$ & 1.50 & 23 & & \\
\hline October 5 & 1.30 & 15 & & \\
\hline October 6 & 1.25 & 13 & & \\
\hline October $7 \ldots$ & 1.75 & 34 & & $\cdots$ \\
\hline October 8 & 4.80 & ${ }^{b} 520$ & & \\
\hline October 9 & 4.35 & $b 365$ & & \\
\hline October 10 & 4.50 & $b 415$ & & \\
\hline October 11 & 3.25 & 171 & & \\
\hline October $12 \ldots$ & 2.70 & 103 & & \\
\hline October 13 & 2.10 & 52 & -. & \\
\hline October $14 \ldots$ & 1.90 & 41 & & \\
\hline October 15 & 1.75 & 34 & $\ldots$ & \\
\hline
\end{tabular}

a Banks overflowed; gage not read.

- No allowance made for overflow water passing around the station. 
There were two floods on this stream in October, one reaching a daily niaximum on October 1, with a gage height at the reservoir gaging station of 10.16 feet, and the second one reaching a maximum on October 8 , with a gage height at Roswell of about 4.8 feet. The second flood was of longer duration than the first, but did not reach as great a stage. On October 1 the water at the gaging station near the reservoir was 1.5 feet above the floor of the bridge from which the discharge measurements are usually made; hence a considerible portion of the discharge must have passed around the gaging station.

The following table gives the gage height of Hondo River at the gaging station near the Hondo reservoir:

Gage height on Hondo River near the reservoir, September 29 to October 9, 1944.

\begin{tabular}{|c|c|c|c|c|c|}
\hline Date. & Time. & $\begin{array}{c}\text { Height in } \\
\text { feet. }\end{array}$ & Date. & Time. & $\begin{array}{l}\text { Height in } \\
\text { feet. }\end{array}$ \\
\hline September 29 & 6 p. m. & 2.20 & October 7 & 8 a. $\mathrm{m}$ & 0.80 \\
\hline September 30 & 9 a. $\mathrm{m}$ & 9.00 & October 7 & 7 p. m... & 5.30 \\
\hline September 30 & 6 p.m $\ldots$ & 10.20 & October 8 & 6 a. $\mathrm{m}$ & 9.15 \\
\hline October 1 & 5 a. m & 9.60 & October 8 & 6.30 a. $\mathrm{m}$ & 9.48 \\
\hline October 1 & 5.30 a. $\mathrm{m}$ & 9.70 & October 8 & 10 a. $\mathrm{m}_{-}$ & 10.64 \\
\hline October 1 & 11 a. $\mathrm{m}$. & 10.20 & October 8 & 2 p. $\mathrm{m}_{\ldots}$ & 10.13 \\
\hline October 1 & 2 p. m & 10.20 & October 8 & 4 p. m.. & 9.70 \\
\hline October 1 & 5 p. m & 10.50 & October 8 & 5 p. m & 10.30 \\
\hline October 1 & $6 \mathrm{p} . \mathrm{m}$ & 9.20 & October 9 & 8 a. $\mathrm{m} \ldots$ & 9.20 \\
\hline October 2 & 6.30 a. $\mathrm{m}$ & 2.00 & October 9 & 5 p. m & 6.90 \\
\hline
\end{tabular}

DAMAGE DONE BY FLOOD.

At Las Vegas and vicinity the Santa Fe Railway bridge was destroyed; loss, $\$ 10,000$. The irrigation company had two or three dams washed away and ditches damaged; loss, $\$ 15,000$. In Las Vegas itself the damage was estimated at $\$ 25,000$.

At Roswell the damage was estimated at $\$ 15,000$. The whole of the business part of the city was under water on September 30 and October 1, and again on October 8 and 9. Many adobe houses were destroyed.

At Carlsbad the Pecos Valley and Northeastern Railway bridge, the Green street highway bridge, and the La Huerta highway bridge were destroyed. The Lake Avalon dam was destroyed and Lake Macmillan and Carlsbad dams badly damaged. The total damage in and around Carlsbad is estimated at $\$ 100,000$. (See Pls. XI, XII, p. 134.)

Considerable silt was deposited in the low valley. In some places 
this deposit is 2 to 3 feet in depth, but it resulted in little damage, as it was not deposited on farming land.

\section{PREVENTION OF FUTURE DAMAGE.}

Floods of great magnitude occasionally occur on this stream and are very destructive to irrigation interests on account of the great slope of its bed. They destroy the dams or cut channels around them, destroy the headgates of canals or form bars in front of them, overflow the irrigable land, deposit immense quantities of silt, sand, and gravel, and in some cases bowlders, filling the canals and covering the land.

The apparent remedy is to store the flood waters. The topography of the country renders storage easy, and the demand for the water for irrigation will add to the value resulting from prevention of overflow.

\section{FAILURES OF LAKE AVALON DAM NEAR CARLSBAD, N. MEX.}

By E. C. Murphy.

Two failures of the Lake Avalon dam have occurred within a dozen years. The dam is located on Pecos River, about 6 miles above the town of Carlsbad, N. Mex., and was built to form a storage reservoir for irrigation purposes. The dam, as reconstructed after the first failure, was a composite structure of loose rock with earth on the upstream side. The total length was 1,380 feet and the maximum height 48 feet. The loose-rock part had a top width of 10 feet, inside slope $\frac{1}{2}$ to 1 , laid by hand; downstream slope $1 \frac{1}{2}$ to 1 , laid by hand. The earth part had a top width of 10 feet and a slope of $3 \frac{1}{2}$ to 1 , riprapped 1 foot thick.

The right bank of the river at the dam is a conglomerate, the left bank is limestone, and the river bed is mixed well. The loose rock used in the dam was the conglomerate taken from the right bank. It is mainly chunks 6 to 18 inches in diameter, with much fine material. It was dumped in place by carts. The earth used was a sandy loam containing some clay, obtained near the dam. It was put in place with carts and scrapers and consolidated by the travel of teams and vehicles over it.

There are three wasteways, one at each end and the other on the right bank about one-half mile from the dam. The principal one was located on the limestone ledge on the right bank and was provided with gates: Its discharge capacity for a water height of 23 feet, or 7 feet below the crest of the dam, was 16,900 second-feet. Spillway No. 1 had a capacity of 5,600 second-feet; No. 2, 7,300 
second-feet; headgates of canal, 3,200 second-feet. The total discharge of the wasteways when the water surface in the lake was 7 feet below the crest of the dam was 33,000 second-feet.

The reservoir when filled to the 23 -foot level had a length of about 5 miles and a maximum width of $1 \frac{1}{2}$ miles; it submerged an area of 1,980 acres and had a capacity of 6,300 acre-feet.

The dam was built in 1894 on the site of the composite loose rock and earth dam that failed during the flood of August, 1893, when the maximum discharge of Pecos River at this place was 43,000 second-feet. The first dam had a lighter cross section than the second and had only one spillway.

The second failure occurred at 11 p. m. October 1, 1904, during a flood of unprecedented magnitude, the rate of flow at this place being, according to the estimate of Mr. V. L. Sullivan, engineer of the Pecos Valley Irrigation Company, 82,000 second-feet. It failed by the water forcing a passage through the dam, not by flowing over the top, but the height above the bed where the earth facing failed could not be ascertained.

Mr. F. G. Tracy, president of the Pecos Valley Irrigation Company, was at the dam at the time of its failure, and states that the water reached a height of about 3 feet below the crest of the dam and remained nearly stationary for a few hours. He thought the danger of failure was over, but shortly after the lake surface at the dam dropped rapidly 3 feet.

He went out on the dam with a lantern and heard the water roaring through the dam, but the crest had not settled. The water continued to fall for some minutes and then appeared to rise for a short time, after which the dam gave way. A section about 450 feet long at the crest and 400 feet at the base was washed out.

There are two opinions as to the cause of the failure. One is that animals burrowed into the earth facing from the downstream side and weakened it; the other is that the failure occurred near the base at the right end. There was some leakage at the latter point, and efforts were made to stop it by sheet piling, but without complete success. Whether the failure was due to animals burrowing or to faulty construction of the dam at the right bank can not be ascertained, as it occurred in the night.

The flood waves caused by both failures were large. At the first one, in August, 1893, all bridges in Carlsbad and the flume that carried water for irrigation across Pecos River were swept away. The flood at the second failure damaged the flume, swept away the three bridges, cut a new channel around the dam at Carlsbad, and eroded the river banks to a considerable extent. It is said that the channel 
in the vicinity of Carlsbad is twice as wide at the present time as prior to the flood of 1893.

Nine miles above Lake Avalon dam is located Macmillan dam, a somewhat larger composite structure having a maximum height of 52 feet and a crest length of 1,686 feet. The side slopes and top width are the same as those of Lake Avalon dam, but the top width of the loose-rock part of the larger structure is $\mathbf{1 4}$ feet and of the earth part 6 feet. This dam was not damaged by the flood, but fears were entertained for its safety, as its spillways were raised a few feet a short time prior thereto.

The writer is indebted to Mr. B. M. Hall, supervising engineer, United States Reclamation Service, and to Messrs. F. G. Tracy, H. Christian, and V. L. Sullivan, officers of the Pecos Valley Irrigation Company, for some of the information used in the preparation of this paper.

\section{RIO GRANDE FLOODS, NEW MEXICO.}

By E. C. Murphy.

During the latter part of September and the early part of October there were frequent and at times quite heavy rains in Texas and southern New Mexico that caused the Rio Grande to overflow its banks at some places. The property loss due to these overflows was not large.

\section{PRECIPI'TATION.}

The precipitation recorded at six places in this drainage basin from September 28 to October 15, 1904, was as follows:

Precipitation in Rio Grande basin, 1904.

Taos

Inches.

Albuquerque 2. 88

Los Iunas.

Socorro

San Marcial

Mesilla Park

2. 86

FLOOD IN SOUTHERN NEW MEXICO.

The following table gives the mean daily gage height and corresponding discharge of the Rio Grande during these floods at three of the gaging stations on it, and from this table the magnitude and duration of the floods can be seen. One of these stations is at Cenicero, Colo., near the Colorado-New Mexico boundary line; another is at San Marcial, N. Mex., about 145 miles north of El Paso, Tex., and the other is near El Paso. 
Daily mean gage height and discharge of Rio Grande, 1904.

\begin{tabular}{|c|c|c|c|c|c|c|}
\hline \multirow[b]{2}{*}{ Date. } & \multicolumn{2}{|c|}{ Cenicero, Colo. } & \multicolumn{2}{|c|}{ San Marcial, N. Mex. $a$} & \multicolumn{2}{|c|}{ El Paso, Tex. $a$} \\
\hline & $\begin{array}{c}\text { Gage } \\
\text { height in } \\
\text { feet. }\end{array}$ & $\begin{array}{c}\text { Dis- } \\
\text { charge in } \\
\text { second- } \\
\text { feet. }\end{array}$ & $\begin{array}{c}\text { Gage } \\
\text { height in } \\
\text { feet. }\end{array}$ & $\begin{array}{c}\text { Discharge } \\
\text { in second- } \\
\text { feet. }\end{array}$ & $\begin{array}{c}\text { Gage } \\
\text { height in } \\
\text { feet. }\end{array}$ & $\begin{array}{l}\text { Discharge } \\
\text { in second- } \\
\text { feet. }\end{array}$ \\
\hline September 27 . & 1.10 & 84 & 9.10 & 950 & 4.70 & 110 \\
\hline September 28 & $b 1.10$ & 84 & $b 10.40$ & 3,030 & 5.35 & 280 \\
\hline September 29 . & 1.20 & 112 & 10.50 & 3,280 & 5.80 & 500 \\
\hline September 30 & 1.50 & 236 & 11.70 & 7,550 & 6.05 & 620 \\
\hline October 1 &, 62.90 & 556 & 11.95 & 8,550 & 7.45 & 1,730 \\
\hline October $2 \ldots$ & 3.00 & 1,865 & 13.10 & 18,400 & 9.55 & $4 ; 040$ \\
\hline October 3 . & $b 2.95$ & 1,800 & b 12. 0 & 19,0 r 0 & 10.80 & 5,410 \\
\hline October 4 & 3. 00 & 1,865 & 9.50 & 5,000 & 11.55 & 6,230 \\
\hline October 5 & 2.90 & 1,735 & $b 8.90$ & 3,200 & 12.10 & 6,850 \\
\hline October 6 & 2. 70 & 1,480 & 8.60 & 2,600 & 12.75 & 8,170 \\
\hline October 7 & $b 2.60$ & 1,355 & 9.10 & 3,000 & 11.50 & 6,180 \\
\hline October $8 \ldots$ & 2.90 & 1,735 & 8.95 & 2,880 & 11.10 & 5,740 \\
\hline October 9 . & 3.30 & 2,125 & 11.55 & 12,000 & 12.55 & 7,670 \\
\hline October 10 & $b 3.75$ & 2,860 & $b 12.85$ & 24,000 & 13.30 & 11,370 \\
\hline October 11 . & 3.95 & 3,150 & 13.75 & 33,000 & 13.15 & 10,550 \\
\hline Octo er 12 & 3.95 & 3,150 & $b 10.60$ & 24,800 & 13.40 & 12,010 \\
\hline October 13 & $b 3.70$ & 2,790 & 9.45 & 21,720 & 13.60 & 13,800 \\
\hline October 14 & 3.50 & 2,520 & 9.00 & 15,900 & 13.90 & 16,200 \\
\hline October $15 \ldots$ & 3.20 & 2,125 & 8.90 & 11,100 & 13.95 & 17,100 \\
\hline October 16 & 3.20 & 2,125 & 8.75 & 6,250 & 11.35 & 9,300 \\
\hline October 17 & $b 3.00$ & 1,865 & 8.65 & 1,550 & 10.35 & 6,300 \\
\hline October 18 & 3.00 & 1,865 & 8.65 & 1,710 & 9.85 & 5,050 \\
\hline October 19 & 2.90 & 1,735 & 8.55 & 1,770 & 9.55 & 4,300 \\
\hline October $20 \ldots$ & 2.80 & 1,605 & 8.40 & 1,780 & 9.25 & 3,550 \\
\hline October 21 & $b 2.60$ & 1,355 & 8.20 & 1,730 & 9.05 & 3,150 \\
\hline October $22 \ldots$ & 2.60 & 1,355 & 8.30 & 1,750 & 8.80 & 2,700 \\
\hline October 23 & 2.50 & 1,230 & 8.25 & 1,620 & 8.65 & 2,460 \\
\hline October 24 & 2.50 & 1,230 & 8.10 & 1,390 & 8.50 & 2,250 \\
\hline October 25 & $b 2.40$ & 1,110 & 8.15 & 1,370 & 8.65 & 2,460 \\
\hline October 26 & 2.20 & 874 & 8.20 & 1,430 & 8.35 & 2,040 \\
\hline October $27 \ldots$ & 2.10 & 762 & 8.10 & 1,240 & 8.15 & 1,800 \\
\hline
\end{tabular}

a Results furnished by W. W. Follett, consulting engineer International Boundary Commission.

${ }^{b}$ Meter measurements.

The rècord at Cenicero, Colo., shows two maximum stages-one October 2 to 4 of 3 feet, and another on October 11 and 12 of 3.95 feet. As the stage at this station is occasionally 6 feet higher than 
either of these stages, it is evident that these floods were almost entirely south of the Colorado-New Mexico boundary line.

The record at San Marcial shows that the Rio Grande at this place reached a maximum stage of 13.1 feet with a discharge of 18,400 second-feet on October 2 and a stage of 13.75 feet and discharge of 33,000 second-feet on October 11 . The second of these floods. was much larger and of longer duration than the first, and the discharge for four consecutive days during the second was larger than at any time during the first. It is interesting to note the effect of the sandy bed of the stream at this place on the height of the flood. Although the discharge on October 11 was 80 per cent greater than on October 2 , the gage height was only 0.65 foot greater on the earlier date. If the bed had been rock or permanent material, the extent of overflow would have been much greater than it was.

At El Paso, Tex., the stream reached a maximum stage on October 6, with a gage height of 12.75 feet and a discharge of 8,170 secondfeet, and on October 15 it reached a stage of 13.95 feet with discharge of 17,100 second-feet. For seven consecutive days during the second flood the discharge at El Paso was greater than at any time during the first.

The following table gives the mean daily discharge of the Rio Grande at seven places on it and of the Pecos, near its mouth, for October, 1904, while the streams of New Mexico, Texas, and Mexico were in flood:

Mean daily discharge, in second-feet, of Rio Grande and Pecos River, October 1 to $31,1904 . a$

\begin{tabular}{|c|c|c|c|c|c|c|c|c|}
\hline \multirow[b]{2}{*}{ Date. } & \multicolumn{5}{|c|}{ Rio Grande. } & \multirow{2}{*}{$\begin{array}{c}\text { Pecos } \\
\text { River at } \\
\text { Moore- } \\
\text { head. }\end{array}$} & \multicolumn{2}{|c|}{ Rio Grande. } \\
\hline & $\underset{\text { Marcial. }}{\operatorname{San}}$ & El Paso. & $\begin{array}{c}\text { Upper } \\
\text { Presidio. }\end{array}$ & $\begin{array}{c}\text { Lower } \\
\text { Presidio. }\end{array}$ & Langtry. & & $\begin{array}{l}\text { Below } \\
\text { Devils } \\
\text { River. }\end{array}$ & $\begin{array}{l}\text { Eagle } \\
\text { Pass. }\end{array}$ \\
\hline October 1 & 8,550 & 1,730 & 0 & 7,770 & 11,350 & 980 & 17,000 & 15,400 \\
\hline October 2 & 18,400 & 4,040 & 0 & 6,200 & 9,250 & 1,150 & 15,510 & 14,640 \\
\hline October 3 & 19,070 & 5,410 & 0 & 3,920 & 9,100 & 890 & 15,060 & 11,880 \\
\hline October 4 & 5,000 & 6,210 & 0 & 4,100 & 9,250 & 760 & 13,960 & 10,430 \\
\hline October 5 & 3,200 & 6,850 & 0 & 4,450 & 8,050 & 715 & 12,560 & 11,600 \\
\hline October 6 & 2,600 & 8,170 & 0 & 3,750 & 6,400 & 675 & 12,810 & 9,280 \\
\hline October 7 & 3,000 & 6,180 & 300 & 4,630 & 6,100 & 590 & 13,510 & 8,640 \\
\hline October 8 & 2,880 & 5,740 & 1,300 & 7,600 & 5,800 & 700 & 11,300 & 8,470 \\
\hline October 9 & 12,000 & 7,670 & 1,750 & 7,950 & 5,800 & 1,260 & 10,640 & 8,800 \\
\hline October 10 & 24,000 & 11,370 & 2,090 & 7,080 & 6,850 & 1,740 & 10,880 & 8,800 \\
\hline October 11 & 33,000 & 10,550 & 2,600 & 8,830 & 10,600 & 1,740 & 13,370 & 10,000 . \\
\hline October 12 & 24,800 & 12,010 & 3,540 & 12,680 & 12,850 & 1,830 & 14,060 & 13,900 \\
\hline
\end{tabular}

IRR $147-05 \mathrm{M} \longrightarrow 10$ 
Mean daily discharge, in second-feet, of Rio Grande and Pecos River, October 1 to 31. 1904-Continued.

\begin{tabular}{|c|c|c|c|c|c|c|c|c|}
\hline \multirow[b]{2}{*}{ Date. } & \multicolumn{5}{|c|}{ Rio Grande. } & \multirow{2}{*}{$\begin{array}{c}\text { Pecos } \\
\text { River at } \\
\text { Moore- } \\
\text { head. }\end{array}$} & \multicolumn{2}{|c|}{ Rio Grande. } \\
\hline & $\underset{\text { Marcial. }}{\operatorname{San}}$ & El Paso. & $\begin{array}{c}\text { Upper } \\
\text { Presidio. }\end{array}$ & $\begin{array}{l}\text { Lower } \\
\text { Presidio. }\end{array}$ & Langtry. & & $\begin{array}{l}\text { Below } \\
\text { Devils } \\
\text { River. }\end{array}$ & $\begin{array}{l}\text { Eagle } \\
\text { Pass. }\end{array}$ \\
\hline October 13 & 21.750 & 13,800 & 4,200 & 16,700 & 14,650 & 2,050 & 14,440 & $-15,400$ \\
\hline October $14 \ldots$ & 15,900 & 16,200 & 4,000 & 17.100 & 19.300 & 2,095 & 20,360 & 20.800 \\
\hline October 15 & 11,100 & 17,100 & 3,630 & 18,300 & 21,250 & 2,630 & 28,880 & 31.000 \\
\hline October 16 & 6,250 & 9,300 & 6,180 & 18,900 & 19,150 & 3,010 & 24,880 & 29,600 \\
\hline October 17 & 1,550 & 6,300 & 9,360 & 18,500 & 21,100 & 3,340 & 25,880 & 28,560 \\
\hline October 18 & 1,710 & 5,050 & 8,910 & 17,500 & 21,400 & 3,680 & 25,480 & 28,420 \\
\hline October 19 & 1,770 & 4,300 & 8,910 & 15,900 & 25,300 & 4,040 & 29,500 & 29,170 \\
\hline October 20 & 1,780 & 3,550 & 7,000 & 13,920 & 20,050 & 4,410 & 26,740 & 31,420 \\
\hline October 21 & 1,730 & 3,150 & 7,000 & 12,480 & 18,700 & 4,660 & 21,980 & 28,420 \\
\hline October 22 & 1,750 & 2,700 & 8,550 & 10,900 & 19,750 & 4,790 & 21,620 & 26,580 \\
\hline October 23 & 1,620 & 2,460 & 6,350 & 10,020 & 16,900 & 5,570 & 19,860 & 26,780 \\
\hline October 24 & 1,390 & 2,250 & 3,540 & 8,270 & 14,800 & 5,460 & 17,900 & 25,090 \\
\hline October 25 & 1,370 & 2,460 & 2,410 & 6,870 & 13,750 & 5,220 & 16,320 & 25,640 \\
\hline October 26 & 1,430 & 2,040 & 2,240 & 6,180 & 12,700 & 4,880 & 16,020 & 21.720 \\
\hline October $2 \tau_{-}$ & 1,240 & 1,800 & 2,240 & 5,490 & 10,300 & 4,360 & 15,870 & 19,240 \\
\hline October 28 & 1,200 . & 1,620 & 2,010 & 7,050 & 8,800 & 3,520 & 14,970 & 16,800 \\
\hline October 29 & 1,160 & 1,620 & 1,800 & 8,100 & 8,650 & 2,780 & 14,370 & 15,160 \\
\hline October $30_{i-}$ & 1,120 & 1,620 & 3,540 & 9,150 & 9,550 & 2,620 & 14,220 & 13,980 \\
\hline October 31 & 1,230 & 1,500 & 2,010 & 6,700 & 11.500 & 2,130 & 13,920 & 15,160 \\
\hline Mean . & 7,534 & 5,960 & 3,403 & 9,903 & 13,194 & 2,719 & 17,544 & 18,735 \\
\hline
\end{tabular}

Fig. 13 shows the location of the above gaging stations.

The following facts may be noted. The flood at San Marcial that had a maximum discharge on October 3 of 19,070 second-feet produced a maximum three days later at El Paso of only 8,107 secondfeet. The second flood reached a maximum at San Marcial of 33,000 second-feet on October 11 and a maximum four days later at El Paso of 17,100 second-feet. These two stations are about 145 miles apart. There are a number of small streams entering between the stations, but no large ones.

The Rio Conchos enters the Rio Grande between the upper and lower Presidio stations, and to it is due the difference in the discharge at the two places. Up to October 7 the Rio Grande was dry above the mouth of the Conchos, the flow at El Paso, which varied from 1,730 to 6,210 second-feet from October 1 to 4 , failing to cause a flow at this place, although they are only about 220 miles apart.

The volume of flow of the Rio Grande at Devils River station 
should be approximately the sum of the volumes of flow at Langtry, of the Pecos at Moorehead, and of Devils River, which is 16,483 as compared with the measured amount of 17,544 second-feet.

There is a gaging station on Devils River near its mouth, but its discharge is not given in the table, as it was nearly constant during

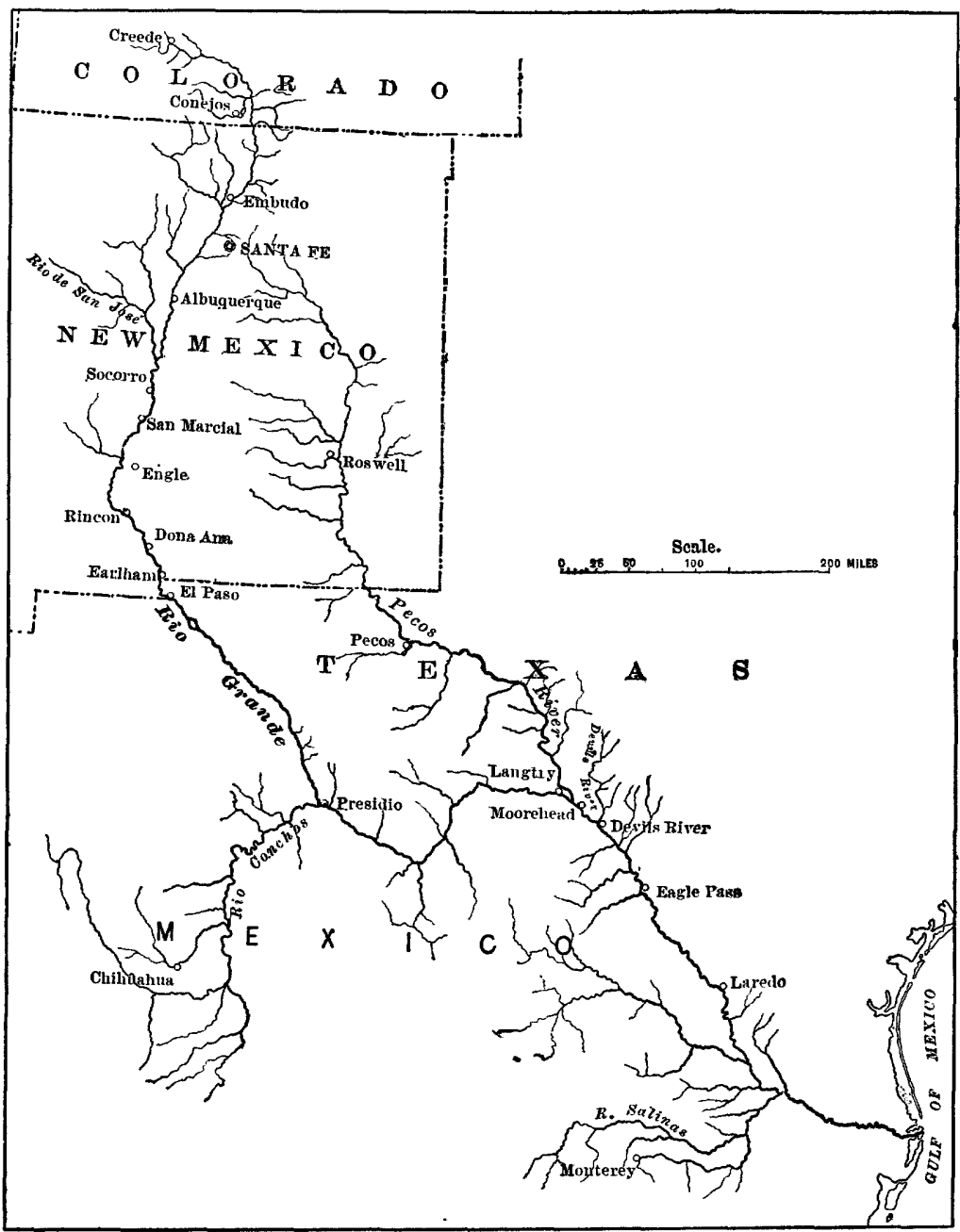

FIG. 13.-Drainage basin of the Rio Grande.

the month, varying only from 530 to 610 second-feet, the mean for the month being 570 .

The flow of the Rio Grande at Eagle Pass for the month was somewhat larger than that at the station just below the mouth of Devils River, owing to the discharge of certain small tributaries entering between these places. 


\section{FLOOD IN NORTHERN AND CENTRAL NEW MEXICO.}

A measurement made at the gaging station at Rio Grande, $\mathrm{N}$. Mex., on September 29 showed a discharge of 606 cubic feet per second, with the water surface 14.05 feet below the floor of the railway bridge. Late in the afternoon of that day the river began to rise and at $11 \mathrm{p}$. $\mathrm{m}$. had reached its maximum stage, 7.6 feet above the stage at which the measurement had been made. A measurement with surface floats was made at 6 o'clock the next morning, with the stage about 1 foot below maximum, and the discharge found to be approximately 28,000 cubic feet per second. At 6 a. $\mathrm{m}$. October 1 a measurement was made and the discharge found to be 2,500 cubic feet per second. The cross section of the stream at this gaging station was found to have been greatly changed by the flood. The maximum discharge at this place was computed to be 30,936 cubic feet per second, and the total volume of run-off from September 29 to October 10, inclusive, 131,782 acre-feet, from a drainage area of 11,250 square miles.

The maximum discharge was also computed by Mr. Monk, using Kutter's formula, with a coefficient of roughness $n=0.025$, and a surface slope $S=0.0007$ feet per foot, and found to be 19,567 cubic feet. It is seen that the discharge, as obtained by the formula, is 30 per cent less than that obtained by the floats. This is probably due to the difficulty of measuring the surface slope.

Albuquerque Valley from the mouth of White Rock Canyon to San Marcial varies in width from one-fourth mile to 3 miles, most of which is under cultivation. As this valley is comparatively flat and very slightly above the level of the river channel, the water spread and covered nearriy all of it. The widening of the stream diminished its force and consequently the damage to buildings was very small, but almost the entire harvest of corn, wheat, and oats was destroyed and the orchards and vineyards damaged to a large extent. The soil, however, was enriched by the sediment and benefited by the washing of the alkali from the land. The town of Albuquerque was affected by the flood to only a slight extent other than the suspension of railway traffic for about ten days. At San Marcial the levees east of the town broke at $6 \mathrm{p}$. m. on October 2 and allower the water to reach the town. In the Mexican quarter of the town 70 houses were rendered uninhabitable, and about 280 people were obliged to seek refuge with friends or in tents. The water in the streets varied in depth from 1 to 2 feet.

The precipitation at Santa Fe, N. Mex., on September 29 and 30 was 2.51 inches, about 0.8 inch greater than for any previous two days' record. This precipitation caused a very large flood in the Santa Fe canyon in the bed of a small stream that is usually dry. 
The flood on this stream reached the storage reservoir at Santa $\mathrm{Fe}$ at $8.30 \mathrm{p} . \mathrm{m}$. on September 29 , and at $10 \mathrm{p} . \mathrm{m}$. had filled the reservoir $(200,000,000$ gallons capacity) and was running over the spillway to a depth of 36 inches. From this time until 2 a. m. on September 30 the river was discharging approximately 750 cubic feet per second. For the following twenty-four hours the discharge fluctuated between 500 and 200 cubic feet per second, then decreased to a flow of 35 cubic feet per second, which stage it maintained for about ten days. It then gradually decreased to zero on October 25.

The flood as it appeared just above the Santa Fe reservoir is described by an eyewitness as a wall of water 8 feet high with a velocity of about 20 miles per hour.

From the first water on September 29 to October 10 the estimated discharge of this usually dry strean was 1,636 acre-feet, after storing in the city reservoir 614 acre-feet.

The Santa Fe Light and Water Company sustained the heaviest loss, which amounted to between $\$ 3,000$ and $\$ 5,000$. The main water pipe into its power house was broken, leaving the city of Santa $\mathrm{Fe}$ without water and light for about forty-eight hours. One of its bridges was washed out and four others were more or less damaged. Other damages were of minor importance.

\section{DAMAGE DONE BY FLOOD. ${ }^{a}$}

The damage done by this flood consisted of: (1) Loss of crops on the area overflowed, consisting of alfalfa, corn, beans, and vegetables. (2) Damage to land along the river that in some places had the soil washed away and in other places was covered with sand. Damage to dams, head-gates of canals, and irrigation ditches. (4) Destruction of houses; many of the houses in this section of the country are built of adobe, and the water soon softened the clay and the houses fell. (5) Damage to highways and railway bridges along the river, some of which had one or more spans taken away by the flood.

\section{Summary of losses from Engle, N. Mex., to El Paso, Tex.}

Las Palomas Valley 
Near Berino and Anthony

La Mesa community

Chamberino

Near El Paso, Tex

Total

\section{FLOODS IN THE DENVER DISTRICT. $a$}

By M. C. HinderLidder and assistants.

\section{REVIEW OF YEAR.}

\section{INTRODUC"TION.}

The year 1904 has passed into history as one of great and destructive floods, this being particularly true of portions of the arid and semiarid sections of the Rocky Mountain districts, in numerous parts of which there have occurred, almost without warning, ruinous floods, which swept everything before them and left wreck and ruin in their wake. What had for years been known only as dry gulches, or arroyos, were suddenly converted into torrential streams, laying waste entire villages, destroying crops, sweeping away homes, drowning live stock and, in some instances, human beings.

Some of the floods were remarkable for the suddenness of their occurrence and the corresponding rapidity of their dissipation and the havoc wrought, others by their occurrence in localities where even more destructive floods had occurred the previous year, others for length of duration, and still others for fearful loss of life which shocked the whole country.

In Colorado there occurred early in the spring a flood of large proportions along the valley of Cache la Poudre River, which, owing to its location in what is probably the most intensely cultivated and valuable agricultural section of the State, caused heavy losses both to individuals and to the towns of Livermore, Fort Collins, and Greeley, and also to railway and ditch corporations; one life was lost. The same storm, precipitating also on the headwaters of Crow Creek, in southern Wyoming, caused that stream to rise to an excessive height within a few hours, resulting in the destruction of a great deal of private and corporate property in Cheyenne, Wyo., and the loss of two lives. A detailed report of this flood, compiled from reports by Messrs. James J. Armstrong, irrigation engineer, and A. J. Parshall, resident hydrographer, appears on pages 156-158.

Doubtless the most destructive flood of the year in Colorado, if

a On account of lack of space it has been necessary to condense certain parts of this report and to omit other parts of minor importance; it has also been found impossible to reproduce many of the accompanying illustrations.-E. C. MURPHy. 
judged by the extent of the financial losses, was that along Las Animas, or Purgatory, River, a southern tributary of the Arkansas. This occurred on October 1 and resulted in heavy losses to railway corporations and to the city of Trinidad. A detailed report of this flood, by R. I. Meeker, assistant engineer, appears on pages 158-169.

Another flood whose results were particularly direful was that of August 7, which occurred in what is ordinarily a dry tributary of Fountain River, and caused the awful Eden disaster on the Denver and Rio Grande Railroad, in which 106 people lost their lives.

During the latter part of September very heavy rains, resembling clond-bursts, occurred in northeastern New Mexico, cansing the Gallinas, Sapello, and Mora rivers to overflow their banks and flood their valleys, and resulting in the destruction of an enormous amount of property and the loss of several lives. Heavy floods on the Rio Grande in this territory were a feature of the season's flood conditions. A destructive flood occurred in La Plata Valley, in New Mexico, on October 6, a detailed account of which is given by Mr. T. Tobish, field assistant, on pages 169-171.

Destructive floods occurred also along Canadian River and Ute Creek, in northeastern New Mexico, and along the Rio Pecos, in the eastern part of the territory, resulting in heavy damage to the Chicago, Rock Island and El Paso Railroad and to the residents along these streams. These floods have been reported by Mr. W. G. Russell; resident hydrographer, of Russell, Kans., and Mr. W. M. Reed, engineer, at Roswell, N. Mex.

FLOOD STATIONS.

In the spring of 1904 , in response to the general desire of the people of Kansas for a Federal investigation of flood conditions in that State, eight river observation stations were established on the streams most generally affected by floods, at points where records of their stage could be secured. In locating these, several things had to be considered, among them the necessity for placing them at points where the records would be of the most value to the residents of the cities and agricultural districts farther down the river, and at points where they might be within easy reach of telegraph or telephone accommodations for transmitting warnings of high and dangerous stages to residents along the lower course of the streams. After due consideration, the following points were selected: Fall River at Fallriver, Kansas River at Solomon, Kansas River at St. George, Kansas River at Topeka, Neosho River at Neosho Rapids, Neosho River at Humboldt, Verdigris River at Independence.

At each of these stations permanent gages were established, observers employed to make the observations, the river channel cross 
sectioned, levels of previous high-water stages taken and connected with permanent bench marks, slopes of channel secured, and information collected regarding the character and damage resulting from previous floods.

The observers were instructed to take daily readings after the stage of the river rose above a certain point, to take such readings hourly, if necessary, during dangerous rises, and to report the same to towns lower down the river. These observations of river stage proved of great value, particularly to the agricultural districts, as the information concerning dangerous rises enabled the farmers to transfer their stock to places of safety before the appearance of a flood. This information during the spring and summer of 1904 prevented losses to the farming communities along Fall River aggregating many thousands of dollars. The telephone companies cooperated in this work by transmitting all messages free of charge. In Colorado, Kansas, New Mexico, and Wyoming the various railway companies extended valuable assistance in the collection of flood data and other furtherance of this work. Some of the data obtained at these flood stations are given in the discussion of floods in southeastern Kansas, pages 59-113.

\section{CAUSE OF FLOODS.}

The cause of the floods in this district has been mainly abnormal rainfall for a short period of time over comparatively small areas. In some cases the failure of artificial works on the stream has increased the flood flow and the destruction wrought.

The flood discharge of a stream is controlled by two factors, viz, rate of run-off from drainage basin and capacity of the channel. If either of these controlling factors can be regulated, the other may be disregarded. To regulate the run-off one requirement is necessary, viz, storage. This may be either natural or artificial in character or both. If natural, the storage will consist of the forest covering of the drainage basin, the character of the soil, and the topography; if artificial, the water must be stored in reservoirs. If, on the other hand, the run-off can not be controlled by storage, the drainage channel must be maintained at such capacity as to accommodate the maximum run-off in the minimum length of time. It sometimes happens that the natural channel is of sufficient capacity to meet the requirements, but this is not often the case; more frequently it is crooked, with banks lined with brush and timber, and more or less obstructed by débris and dams, which change the natural grade of the river, and by low-spanning bridges, piers, and abutments, loose riprap, and other serious encroachments on the banks such as are generally found in cities where the river banks are made the dumping ground for the city garbage. 
The data in the accompanying reports illustrate the great destructiveness of floods. As an instance of their suddenness when resulting from the so-called cloud-bursts may be cited the case in Colorado, in which an entire train load of unsuspecting people were plunged into a roaring torrent, which, but a few minutes previously, had been a harmless dry arroyo.

The results of floods are manifold, the most important, doubtless. being the financial losses incurred, which may amount to millions of dollars in a comparatively small area; in addition they often cause great hardships, including loss of life and the suffering and sickness caused by exposure and privation. Some of the greater losses affect the country not only locally, but at large. Among those may be mentioned the destruction of farms, as was the case in considerable areas along Kansas River after the great flood of 1903 . What had been fertile and productive farms prior to the flood were washed, worthless stretches of sands after its subsidence.

The destruction of mills or of dams furnishing water power for irrigation works, bridges, etc., is a blow to the whole section of the country where they occur.

Damage to or destruction of a system of sewerage, drainage, or water supply is very apt to injuriously affect the health of a city or community, and it frequently happens that an epidemic follows such an occurrence, and, finally, the effect of damage to any one of the staple crops is always reflected on the various markets of the world and may cause unsettled conditions of the business of a whole country.

PREVENTION OF FUTURE DAMAGE.

In considering this phase of the problem streams may be divided into three classes and each class treated separately in accordance with the natural conditions" of the country.

(1) Mountainous streams, i. e., streams having their sources and their courses mostly in a mountainous country where the percentage of rainfall is large and the run-off rapid.

(2) Arid-plains streams, i. e., streams that head or flow through an arid or semiarid plains country, where the precipitation is small, the evaporation large, and the run-off small.

(3) Streams flowing through a comparatively level or rolling country having a humid climate, where the rate of run-off may be either rapid or sluggish.

In the case of mountain streams forests generally equalize the rate of run-off. In the absence of these recourse to storage must be had to equalize the flow. 
In the case of plains streams, where the water is needed for irrigation, the great problem is the storage of the water. Generally, however, the topography is such that it is very difficult to find reservoir sites of any considerable size.

Probably the most practical plan for the partial elimination of some of the dangers from floods in humid sections of the country would be the careful protection of the remaining forests along these streams, the reforesting of the sections of the bottom lands rendered worthless by recent floods, the enactment and enforcement of State laws regulating the erection of bridges and preventing any encroachment on the natural waterway by individuals or corporations, and the dredging and straightening of river channels where necessary.

\section{CACHE LA POUDRE RIVER AND CROW CREEK FLOOD.a}

\section{PRECIPITATION.}

On May 20 a very heavy local rainfall in the southwestern part of Laramie County, Wyo., and the northeastern part of Larimer County, Colo., caused North Fork of Cache la Poudre River and its tributaries and Crow and Lone Tree creeks (which join Platte River near Greeley) to be in destructive flood on the night of May 20 and the forenoon of May 21.

That the area over which heavy precipitation occurred was small can be approximately seen from the measured depth of rainfall on May 20, given in the following table, prepared from the United States Weather and Crop Service report:

Precipitation, in inches, in Colcrado and Wyoming, 1904.

\begin{tabular}{|c|c|c|c|}
\hline Place. & May 19. & May 20 . & May 21. \\
\hline Cheyenne, Wyo..... & $\mathbf{T}$. & 1.73 & 0.15 \\
\hline Laramie, Wyo _... & & .15 & $.0 \%$ \\
\hline Greeley, Colo. & & .09 & $\ldots \ldots$ \\
\hline Fort Collins, Colo $\ldots$ & $\mathbf{T}$. & .21 & $\cdots$ \\
\hline Boulder, Colo ...... & & $\mathbf{T}$. & .03 \\
\hline Alford, Colo $\ldots . . .$. & & 2.66 & $\ldots \ldots$ \\
\hline Grover, Colo $\ldots \ldots$ & & .30 & $\ldots$ \\
\hline Denver, Colo & & T. & .01 \\
\hline
\end{tabular}

The location of these precipitation stations and the streams in this locality can be seen from fig. 14 .

a From reports of James A. Armstrong, irrigation engineer, and A. J. Parshall, resident hydrographer. 
FLOOD ON CACHE LA POUdRE RIVER.

The storm appears to have originated in the Stonewall Mountains and range of upper foothills at the head of North Fork of Cache la Poudre River, and to have covered Dale, Lone Pine, Stonewall, and Dry creeks, and also Lone Tree and Crow creeks. It began about noon on May 20 and lasted five or six hours. A considerable portion of this country being rough, with steep slopes entirely destitute of

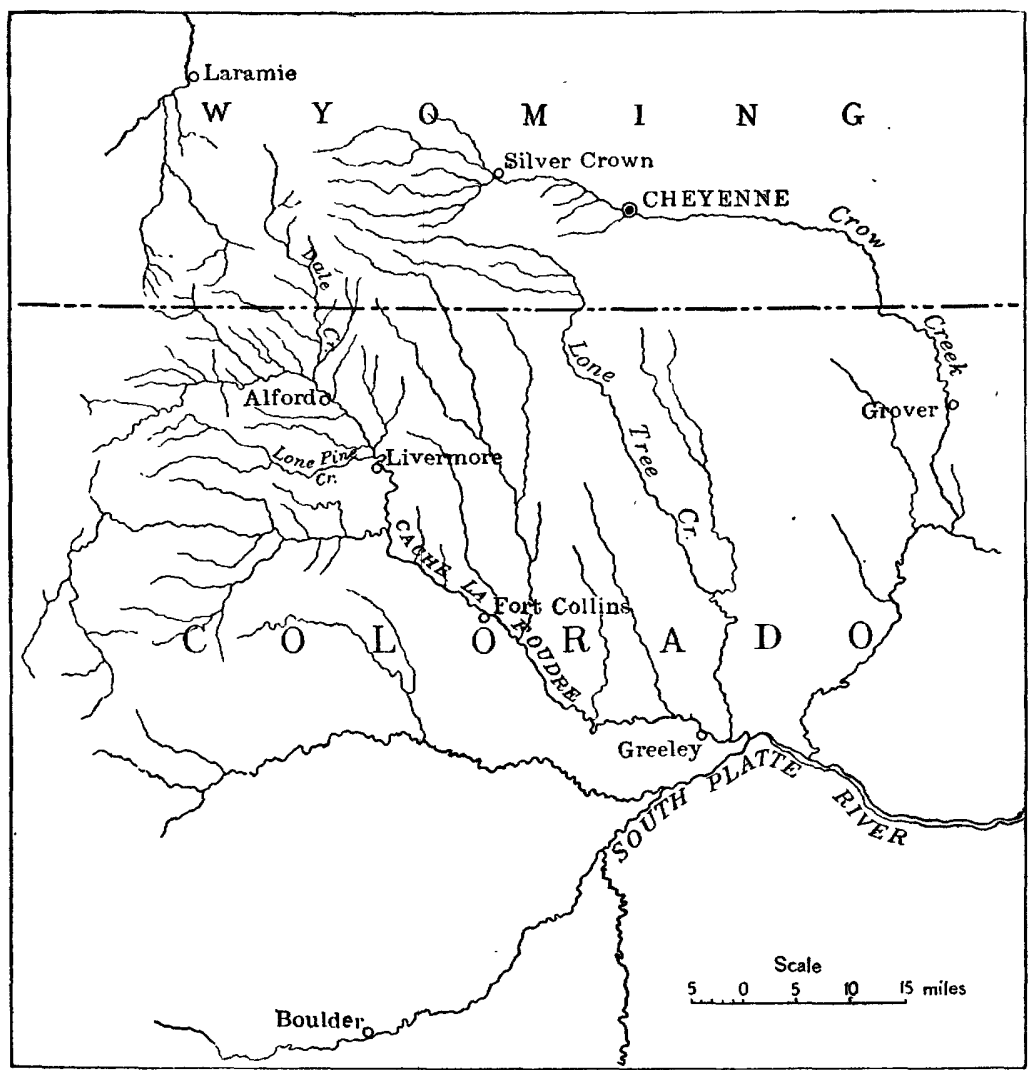

FIG. 14.-Drainage basins of Cache la Poudre River and Crow Creek.

timber, and the beds of the streams being very 'steep, the run-off was very rapid. Mr. Armstrong thus describes the flood on the Cache la Poudre:

The flood was down into Livermore almost before anyone could remove anything out of the way, and had it been in the night there would probably have been a great loss of life as well as of property. The flood reached the main Cache la Poudre early in the afternoon, and was augmented by floods down Dry Creek and Hook and Moore canyons, which empty into the main Cache la Poudre below the mouth of the canyon. These probably added as much more water to the already swollen stream. 
The flood was at its height at Fort Collins late in the afternoon and early evening, remaining up from two and one-half to three hours. From Fort Collins to Greeley the river has less' grade than in the hills and the water traveled more slowly, giving the people time to prepare, as they were warned in ample time. As the bottom lands are much wider, the flood did not reach Greeley until about 6 a. $m$. on the morning of May 21.

Mr. Armstrong estimates the maximum rate of discharge at Livermore at 20,000 cubic feet per second, and states that this flood was the greatest in at least thirty-four years. People living in the valley since 1859 declare that this flood was 1.5 feet higher than the great flood of 1864 .

The loss in Larimer and Weld counties, Colo., consisted mainly in damage to farm property, to irrigation ditches, to roads and bridges, and to railway property. These are summarized in the following table:

\section{Damage from Cache la Poudre flood in Colorado.}

Larimer County :

Homes and farms $\$ 62,250$

Ditches 35,000

Roads and bridges. 50,000

Weld County : $\$ 147,250$

Homes and farms

Roads and bridges._. 5,000

Railroad bridges and tracks washed out, Colorado and Southern and Union Pacific, in both the above counties.

Total loss in these two counties

183,650

\section{FLOOD ON CROW CREEK.}

The storm on Crow Creek appeared to have been greatest near the junction of South, Middle, and North forks, about 18 miles west of Cheyenne. When visited by Mr. Parshall, two days after the storm, there was no evidence of a heavy storm above this place, while below it on every side were seen torn fences and great deposits of silt and débris.

Mr. Parshall thus describes the flood at places along Crow Creek:

About 9 p. m. on May 20 the residents along Crow Creek were suddenly confronted by a wall of water several feet high extending across the valley, varying in width from one-fourth to one-third of a mile, and moving with great rapidity. The resulting damage was the loss of the lives of two children and the destruction of a considerable amount of property, viz, of railway and highway bridges, embankments, public works, and residences. The first alarm at Cheyenne was sounded from the city pump house, a substantial stone structure located near the creek in West Cheyenne, its floor being about 7 feet above the 
bed of the stream and about 120 feet distant from it. At $9 \mathrm{p}$. $\mathrm{m}$. May 20 the engineer and family living in the house were warned of some unusual occurrence by a roaring noise, and opening the door were almost simultaneously struck by a wave estimated to have been 3 feet high. The water continued to rise for about three-fourths of an hour, when it reached its greatest height, $\mathbf{5 . 5}$ feet above the floor of the building and 12.5 feet above the bed of the creek. Here the width of the bottom covered with water was nearly one-fourth of $a$ mile. After 10 o'clock the water gradually subsided, and at daylight the following morning only a swollen stream with slimy, wreck-strewn banks was to be seen.

State Engineer Johnson was on the ground at the time and estimated the discharge of the creek at Cheyenne to vary from 7,000 to 10,000 cubic feet per second for several hours, this estimate being based on his knowledge of discharge of streams. The loss caused by the flood consisted mainly of damage to railway property, the Colorado and Southern Railway Company being without doubt the heaviest property loser. The points of greatest destruction were between the junction of the forks and Cheyenne. Immediately below the junction is the roadbed of the Colorado and Southern, lying close to the stream and largely constructed on embankments. Farther down are the filter beds of the Cheyenne city waterworks, and 15 miles from the junction the city of Cheyenne, where the creek passes under the tracks of the Union Pacific Railroad.

The bridge at Silver Crown station (13 miles west of Cheyenne) was washed out, and between that point and the city 4 or 5 miles of roadbed was washed away. The destruction was complete, scarcely one rail being left in place, and where the embankment stood the creek, when the storm had subsided, had in many places cut a new channel.

The loss to the city of Cheyenne was considerable. A portion of the dam used in connection with the filter beds was washed away, the beds covered with a mass of mud and débris, and a portion of the flume, which conveyed the water to the locks, was destroyed.

The iron bridge which spanned Crow Creek at Nineteenth street was wrecked and the wooden bridge at Fortier Park, Sixteenth and South Cheyenne streets, was entirely carried away. The Union Pacific Railroad Company lost its big pile bridge over the creek on the Denver line, and was obliged to replace a large amount of washedout embankment near the city.

Several houses belonging to the poorer classes were carried downstream and many more were flooded with water, some having been twisted around upon the lots and greatly damaged.

The loss to the ranchmen along the stream was not as great as at first supposed, for while many fences and small buildings were destroyed and lands covered with silt, yet, generally, the silt had a 
beneficial effect upon the land, and the crops later in the season showed a marked improvement over those of former years. An approximate estimate of the damage done along this creek is as follows:

Damage from Crow Creek flood, 1904.

Colorado and Southern Railway

$\$ 40,000$

City of Cheyenne

15,000

Union Paciflc Railroad

10,000

Individual losses

10,000

Total

75,000

\section{PURGATORY RIVER FLOOD. $a$}

The largest and by far the most destructive flood recorded in the history of Purgatory River occurred from $10 \mathrm{p}$. m. September 29 to 8 a. m. September 30, 1904. All the city bridges in Trinidad were washed away or badly damaged, the city water supply was cut off by the destruction of the main pipe line, the electric-light plant was disabled, telephone communications were cut off, and railway services were entirely abandoned. In three hours public, private, and corporate property was damaged to the extent of $\$ 350,000$. No lives were lost, an almost miraculous fact considering the suddenness and magnitude of the flood and its occurrence in the night.

\section{STREAM AND DRAINAGE BASIN.}

Purgatory River rises in the Culebra Mountains in the southwestern part of Las Animas County, Colo., flows in a general northeasterly direction, and joins the Arkansas near Las Animas, Colo. The drainage basin is about 120 miles long and from 30 to 40 miles in width and comprises an area of about 3,390 square miles.

The upper and mountainous part, lying above Trinidad, has an area of 742 square miles and consists mainly of shales and sandstone, with some igneous rocks. It is carved into valleys where the formation is shale and into canyons where the formation is more resisting. The vegetation of the lower half of this area is largely cedars and bunch grass; of the upper portion pine, cedar, fir, and the usual Colorado mountain flora. Ground storage of rain in this part of the basin is small owing to the steep slopes.

The lower part, having an area of 2,640 square miles, extends from Trinidad to the mouth of the river. The soil here is largely decomposed shale, with some sand and limestones. The vegetation consists of cedars, bunch grass, cactuses, etc. Surface storage is small. This is a characteristic stream of eastern Colorado, heading in the mountains, flowing across the plains, and carrying little water except dur-

a By R. I. Meeker, assistant engineer. 
ing floods. It is the principal southern tributary of Arkansas River. In the spring the channel carries a moderate volume of water, but as summer approaches this is gradually diminished by irrigation and

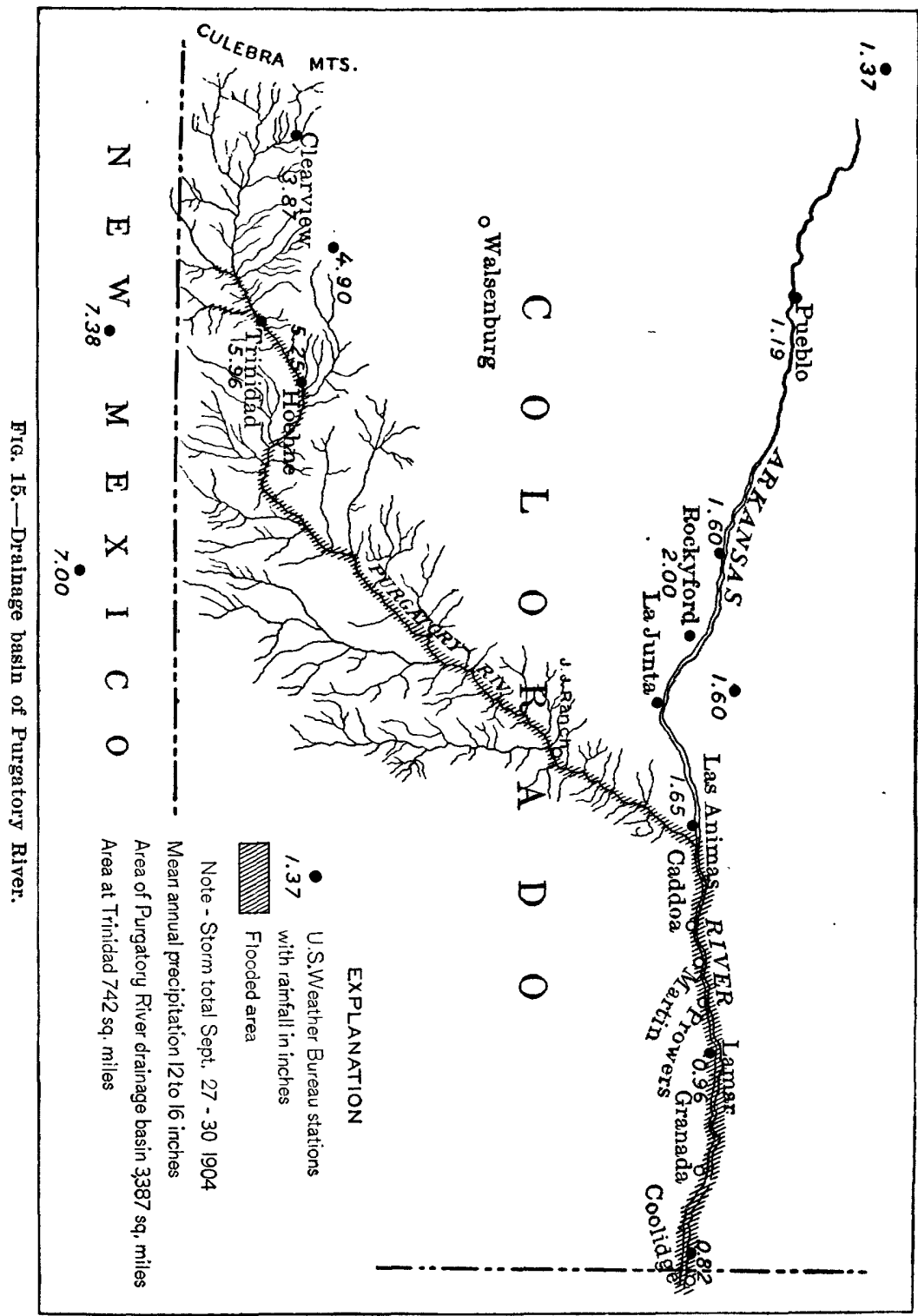

natural conditions until the channel is practically dry. The volume of water contributed to the Arkansas by this stream is so small that it has scarcely an appreciable effect upon the discharge of the Arkansas, except at times of excessive local rainfall. Its flow is very 
erratic; the discharge may vary from a few second-feet to several thousand in a few hours.

PRECIPITATION.

The mean annual precipitation over this drainage basin varies from about 13 inches near the mouth to about 23 inches near the source, the September average from source to mouth being from about 1 inch to 1.2 inches. The following table ${ }^{a}$ gives the depth of rainfall for the month of September, 1904, at several places along Arkansas and Purgatory rivers:

Precipitation, in inches, in Purgatory River basin, Colorado, for September, 1904.

\begin{tabular}{|c|c|c|c|c|c|c|c|c|c|c|}
\hline Day. & $\begin{array}{l}\text { Santa } \\
\text { Clara. }\end{array}$ & $\begin{array}{l}\text { Fow- } \\
\text { ler. }\end{array}$ & $\begin{array}{l}\text { Rocky } \\
\text { Ford. }\end{array}$ & Sugar & $\begin{array}{l}\text { Las } \\
\text { Ani- } \\
\text { mas. }\end{array}$ & $\begin{array}{l}\text { Clear } \\
\text { View. }\end{array}$ & $\begin{array}{c}\text { Trini- } \\
\text { dad. }\end{array}$ & Hoehne. & $\begin{array}{c}\text { La- } \\
\text { mar. }\end{array}$ & Holly. \\
\hline 1. & T. & 0.26 & 0.16 & 0.17 & 0.20 & & 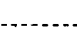 & & 0.60 & 0.22 \\
\hline 2 & $\mathbf{T}$ & .55 & .18 & .25 & .10 & - & 0.28 & 0.12 & .17 & .98 \\
\hline 3 & - & & & & & 0.14 & & & & \\
\hline 9. & $\mathbf{T}$. & & & & & & & & & \\
\hline 10. & 0.05 & -- & & & & $\mathbf{T}$ & & & & 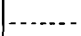 \\
\hline 12. & . & & & & & & & T. & & \\
\hline 14 & .05 & & & & & $\cdots$ & & & & - \\
\hline 15 & $\mathbf{T}$ & & & & & .08 & & & & $\ldots$ \\
\hline 18 & $\mathbf{T}$ & $\cdots$ & & - & & .10 & $\ldots$ & $\mathbf{T}$. & & $\ldots$ \\
\hline 19 & T. & T. & T. & .07 & & .14 & $\mathbf{T}$. & T. & & -... \\
\hline $20 \ldots$ & $\mathbf{T}$ & & & & & $\ldots$. & $\cdots$ & & & . \\
\hline 21. & $\mathbf{T}$ & - & & & & $\ldots$. & .55 & $\ldots$ & & -... \\
\hline 22 & $\mathbf{T}$. & - & & & & $\mathbf{T}$ & $\cdots$ & $\cdots$ & & ... \\
\hline 23. & -- & - & & & & .05 & $\ldots$ & & & $\ldots$ \\
\hline 25 . & $\mathbf{T}$ & . & & $\cdots$ & & .03 & $\cdots$ &.- & & $\cdots$ \\
\hline 26 . & $\mathbf{T}$ & & $\cdots$ & $\mathrm{T}$. & & .04 & $\ldots$ & & & $\ldots$ \\
\hline 27 & $\mathbf{T}$. & .25 & T. & T. & & .48 & .18 & $\ldots$ & .11 & $\ldots$ \\
\hline 28 & .75 & .25 & .13 & .06 & $\ldots$ & 2.03 & .72 & .10 & .18 & .28 \\
\hline 29 & 1.79 & 1.10 & 1.49 & 1.46 & 1.20 & 1. 36 & 1.92 & 3.00 & .41 & .52 \\
\hline 30 & 2.36 & $\mathbf{T}$. & .38 & .08 & .45 & (n........ & 3.13 & 2.15 & .26 & .02 \\
\hline Total. & 5.00 & 2.41 & 2.34 & 2.09 & 1.95 & 4.45 & 6. 78 & 5.37 & 2.59 & 2.27 \\
\hline $\begin{array}{l}\text { Departure from } \\
\text { the normal }\end{array}$ & +3.17 & & +1.69 & & +1.05 & +3.46 & +5.71 & +4.37 & +1.54 & +1.00 \\
\hline
\end{tabular}

The following table gives the daily depth of rainfall at three places in this basin from September 26 to 30, 1904:

Precipitation, in inches, preceding Purgatory River flood, 1904.

\begin{tabular}{|c|c|c|c|c|c|c|}
\hline Place. & $\begin{array}{l}\text { Eleva- } \\
\text { tion in } \\
\text { feet. }\end{array}$ & Sept. 27.b & Sept. 28. & Sept. 29. & Sept. 30. & Total. \\
\hline Trinidad & 6,000 & 0.18 & -0.72 & 1.92 & 3.13 & 5.95 \\
\hline Hoehne . . . . . . & 5,271 & 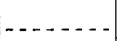 & .10 & 3.00 & 2.15 & 5.25 \\
\hline Clear View & 9,500 & .48 & 2.03 & 1.36 & $\ldots \ldots$ & $3.8 \%$ \\
\hline
\end{tabular}

${ }^{a}$ Prepared from records of United states Weather Bureau.

${ }^{b}$ From 5 p. m. Sept. 26 to 5 p. m. Sept. 27. 
The location of the precipitation stations along Arkansas and Purgatory rivers are shown in fig. 15 (p. 159).

On September 27 a moderate rain began to fall over the upper part of the Purgatory drainage basin, continuing with increasing intensity until the evening of September 29 , when it became excessive. Up to 9 p. m. on September 29,4 inches fell at Trinidad, and from that hour to 9 a. m. September 30,2 inches more fell. By this time the storm had grown in extent and had become general over the entire drainage basin. It was heaviest along the southern mountain watershed of the Purgatory above and below Trinidad, and traveled slowly from west to east. This movement, together with the physical character of the southern portion of the drainage basin, accounts for the immense amount of water which arrived at the mouth of the Purgatory. The rainfall of the upper tributaries reached Trinidad almost simultaneously with the greater portion of the flood, which came into the Purgatory from Long Creek, about 6 miles above Trinidad.

\section{FLOOD ON PURGATORY RIVER PROPER.}

Flood near Trinidad.-Trinidad is located in the narrow valley where the Purgatory leaves the mountains, the business portion of the town lying along each side of the river and the residence portion on higher ground. The slope of the bed of the river at this place is from 39 to 40 feet per mile, and the sides of the ralley are steep, being mainly shale, highly eroded, and cut into well-rounded quickwater channels, causing the run-off to be rery rapid. Purgatory River at Trinidad was not carrying more than the usual volume of water until the evening of September 29 , when the very heavy rainfall caused the river to rise very rapidly. Local information is conflicting as to the exact cause of the large volume at Trinidad. Some of the residents report a cloud-burst above the city in the river canyon, or elsewhere; others maintain that the origin of the great volume was the increasing heavy downpour. From personal investigation Mr. Meeker was led to the conclusion that the great volume was due to the excessive rainfall of a few hours, following a constant rain of about three days over an area of very rapid run-off.

At Weston, 20 miles above Trinidad, the Purgatory, though high, did not overflow its banks. Between this point and Trinidad the volume discharged into the Purgatory from southern tributaries was exceptionally large. Local residents all agree that Long and Raton canyons discharged an immense volume of water on the night of September 29. This large discharge from southern tributaries indicates a greater rainfall to the south, which is corroborated by heavy rainfall records in northern New Mexico.

IRR $147-05 \mathrm{M}-11$ 
A trustworthy eyewitness, employed at the Cardenas Hotel at Trinidad, describes the flood at this place as follows:

The river was high on the afternoon and erening of September 29 , and rose steadily during the early part of the night. At $11 \mathrm{p}$. $\mathrm{m}$. the water level was still 1.5 feet below the level of the river banks and about 5 feet deep in the channel. Shortly after this time the river rose rapidly, and by 2.30 a. m. was at its highest stage, being 2 feet deep on the lawn of the Cardenas Hotel and within 5 inches of the hotel floor. This stage of the river lasted until about $4 \mathrm{a}$. $\mathrm{m}$., when it began to fall. By 8 a. m. on September 30 the river was again within its banks and was rapidly receding.

At the Atchison, Topeka and Santa Fe Railway station, shown in $\mathrm{Pl}$. XV, the water reached a depth of 3 feet on the platform.

In three hours $\$ 350,000$ worth of property was destroyed. Of the five street bridges and two railway bridges four were swept entirely away and others were badly damaged. Several brick and stone structures adjacent to the river were destroyed. The supply main of the city water supply was carried downstream, thus disabling the service. All the railroads suffered heavily in yard tracks, bridges, and roadbeds, being completely iied up for twenty-four hours. The entire lower portion of the city was submerged for some hours, being flooded to a depth of from 1.5 to 2 feet. A large steel bridge belonging to the Colorado and Southern Railway was carried downstream 250 feet and half buried in sand and rocks. The piers were overturned and forced out of the river bed, one of them, 5 feet in diameter and concrete filled, being entirely destroyed. The city bridge at Commercial street, a steel structure on masonry piers accommodating an electric railway in addition to road and foot ways, was carried one-fourth mile downstream and reduced to a shapeless mass of twisted steel. The losses in the vicinity of Trinidad may be summarized as follows:

Losses from Purgatory River flood at Trinidad, Colo., September, 1904.

Corporation property :

Atchison, Topeka and Santa Fe Railway__._._...... $\$ 70,000$

Colorado and Southern Railway

Colorado and Wyoming Railway _._._._-_._-_._- 18,000

Denver and Rio Grande Railroad _._._._._._._._. 30,000

other corporation property, about one-half of which was

at Elmoro _..._.

Public property :
New bridges and repairs to bridges._. 50,000

Straightening channel, etc _._._._. 25,000

General _- 25, 000

Private property :

Estimated_...

Total

350,000 

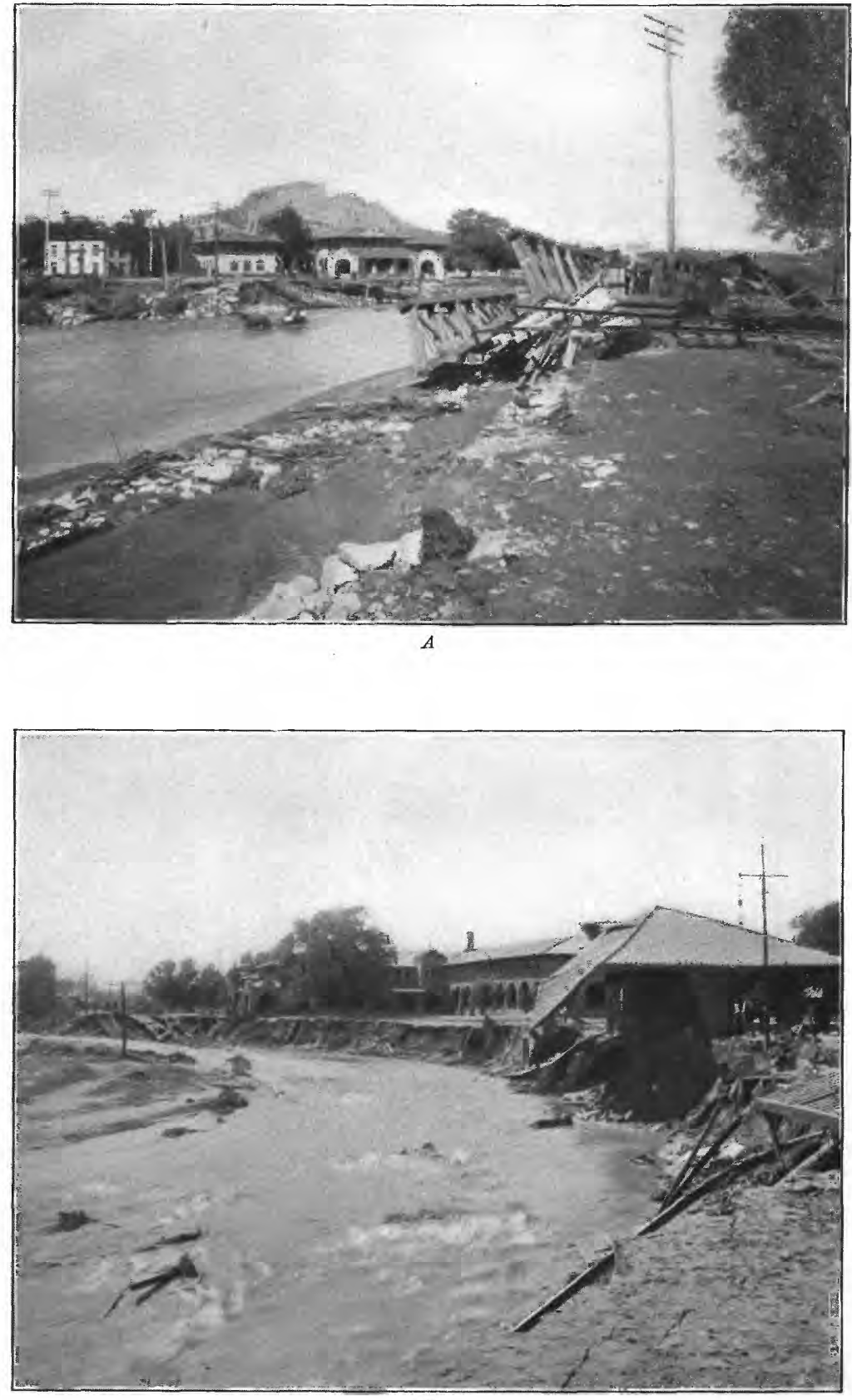

$B$

DESTRUCTION CAUSED BY FLOOD ON PURGATORY RIVER AT TRINIDAD, COLO. 


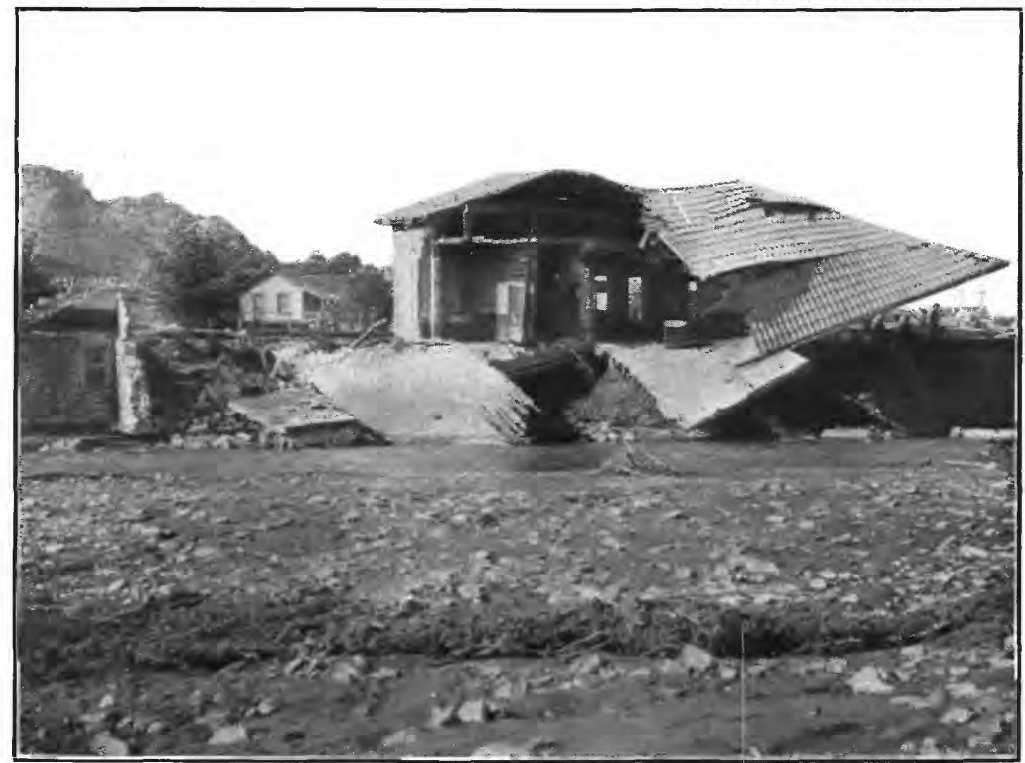

A. ATCHISON, TOPEKA AND SANTA FE RAILWAY STATION AT TRINIDAD, COLO., AFTER FLOOD OF SEPTEMBER, 1904.

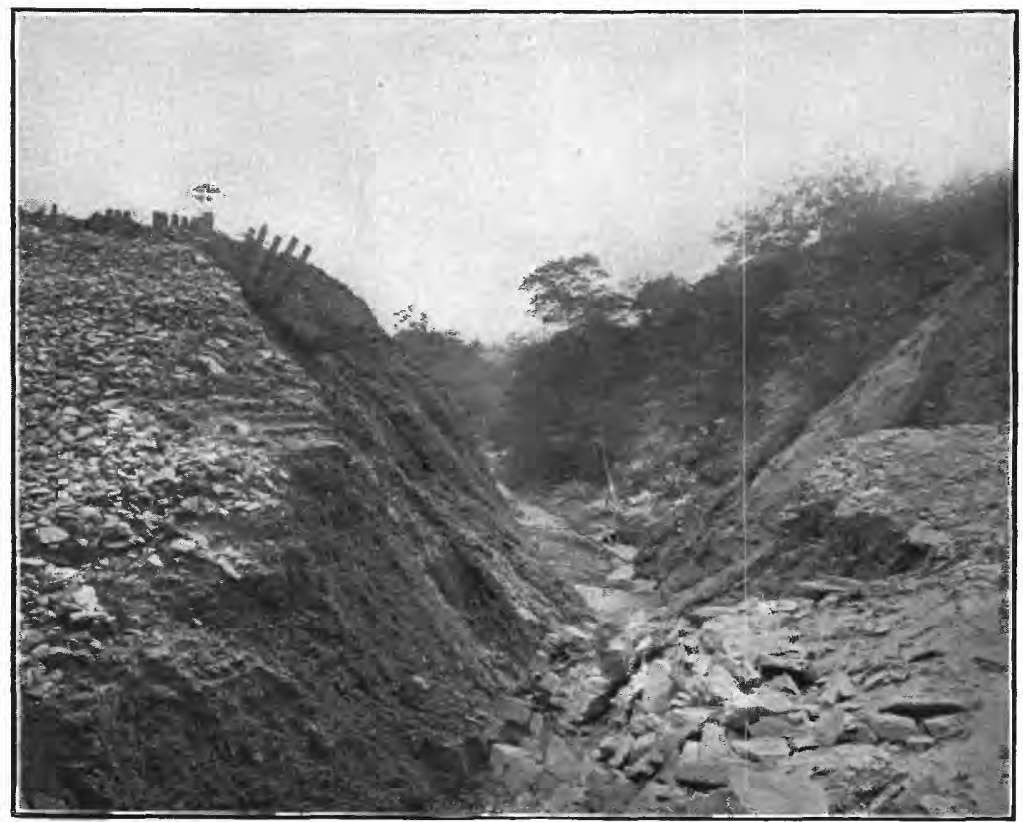

$B$ VIEW SHOWING FAILURE OF DAM NEAR SCOTTDALE, PA, 
An old resident who came to Trinidad in 1862 states that at that time the channel of Purgatory River was narrow, not over 30 or 40 feet in width, and that it has increased in width each year since that

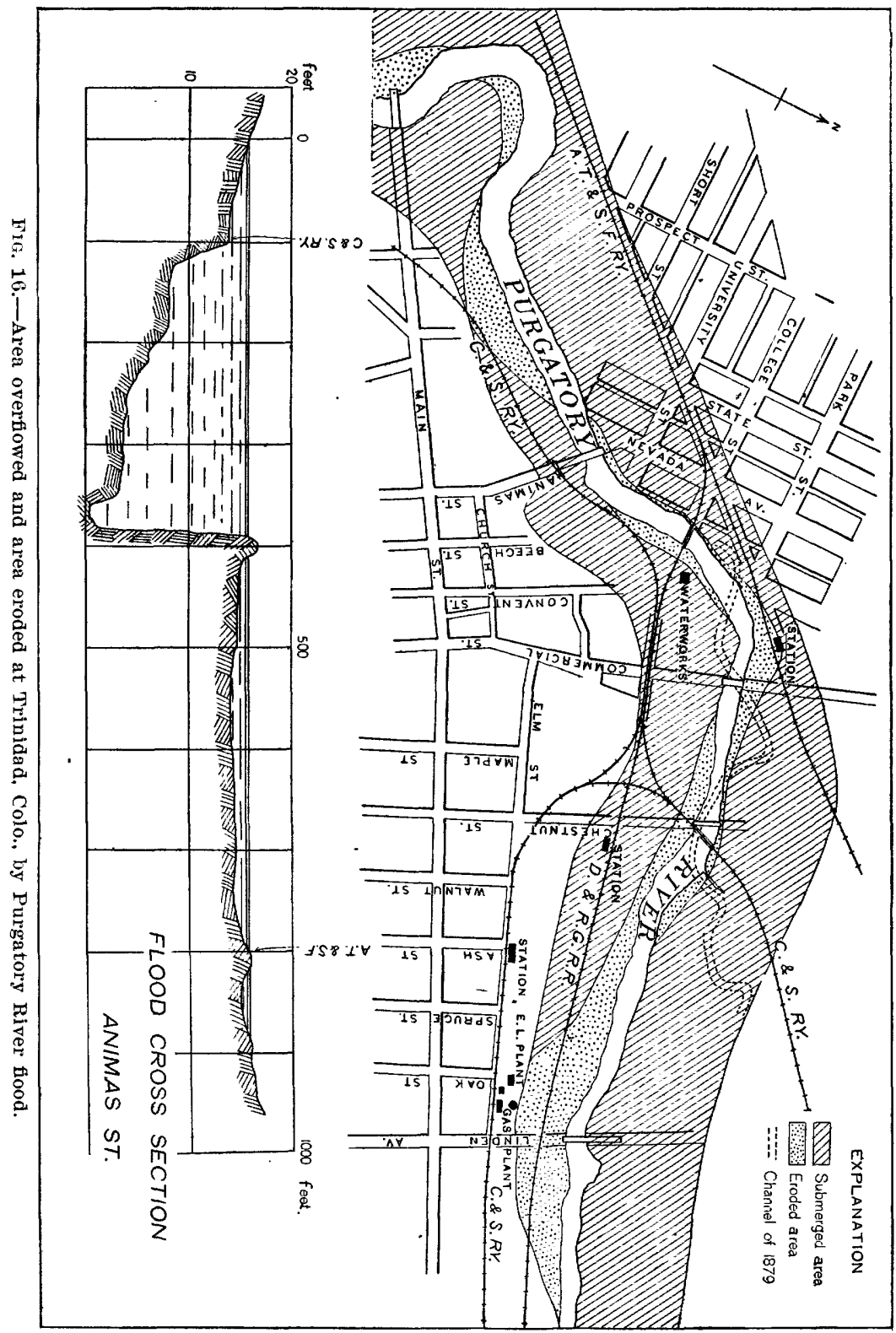

time. A flood occurred at Trinidad in November, 1866, and since that time there have been two large floods at this place, the exact dates and volume of discharge of which could not be secured. Old resi- 
dents agree that the flood of September, 190t, was considerably larger than any previous one. The changes in the channel in the vicinity of Trinidad caused by the 1904 flood are shown in Pl. XVI. The area submerged during the flood and a cross section of the stream near the Animas Street Bride are shown in fig. 16.

The maximum discharge of the river at Trinidad was computed by the use of Kutter's formula. A section was selected just below the Animas Street Bridge, where the channel is approximately straight and the change in it caused by the flood comparatively small. The bed here is composed of sand, gravel, and cobbles. The banks are mainly of earth, with a few trees, and in places it is protected with riprap or piling. The old United States Geological Survey gage on the Animas Street Bridge showed a maximum reading during this flood of 16.6 feet. The slope of the river was measured with a level for a distance of about 500 feet above and below this section and found to be about 37 feet to the mile. The area of cross section is 2.670 square feet, wetted perimeter 275 feet, hydraulic radius 9.71 feet, and the coefficient of roughness tras taken as 0.03 .5 . The mean velocity was found to be 16.61 feet per second and the discharge 44,322 cubic feet per second. The estimated volume of water not included in this section, passing on the right and left banks, is 1,100 second-feet; the maximum rate of flow was, therefore, 45,422 . cubic feet per second. The mean rate of flow from September 28 to October 2 , inclusive, was 5,061 cubic feet per second, and the total approximate discharge 50,000 acre-feet. This result is based upon depth of water in river from September 28 to October 2 , as given by local residents.

The detailed estimated discharge from. September 28 to October 2 , inclusive, was as follows:

Discharge, in second-feet, of Purgatory River at Trinidad, Colo., 190\%.

September 28

1,400

September 29

5,594

September 30

15,583

October 1

2,000

October 2

750

On October 3 a discharge measurement was made from a temporary footbridge at Commercial street and the discharge found to be 270 cubic feet per second.

Flood belou Trinidad.-From Elmoro to the mouth of Purgatory Canyon, a distance of 28 miles, the valley widens and is occupied by farms and ranches on either side for the entire distance. These ranches were injured to a considerable extent. Fences and hay were washed away, cattle and hogs drowned, and minor dam- 


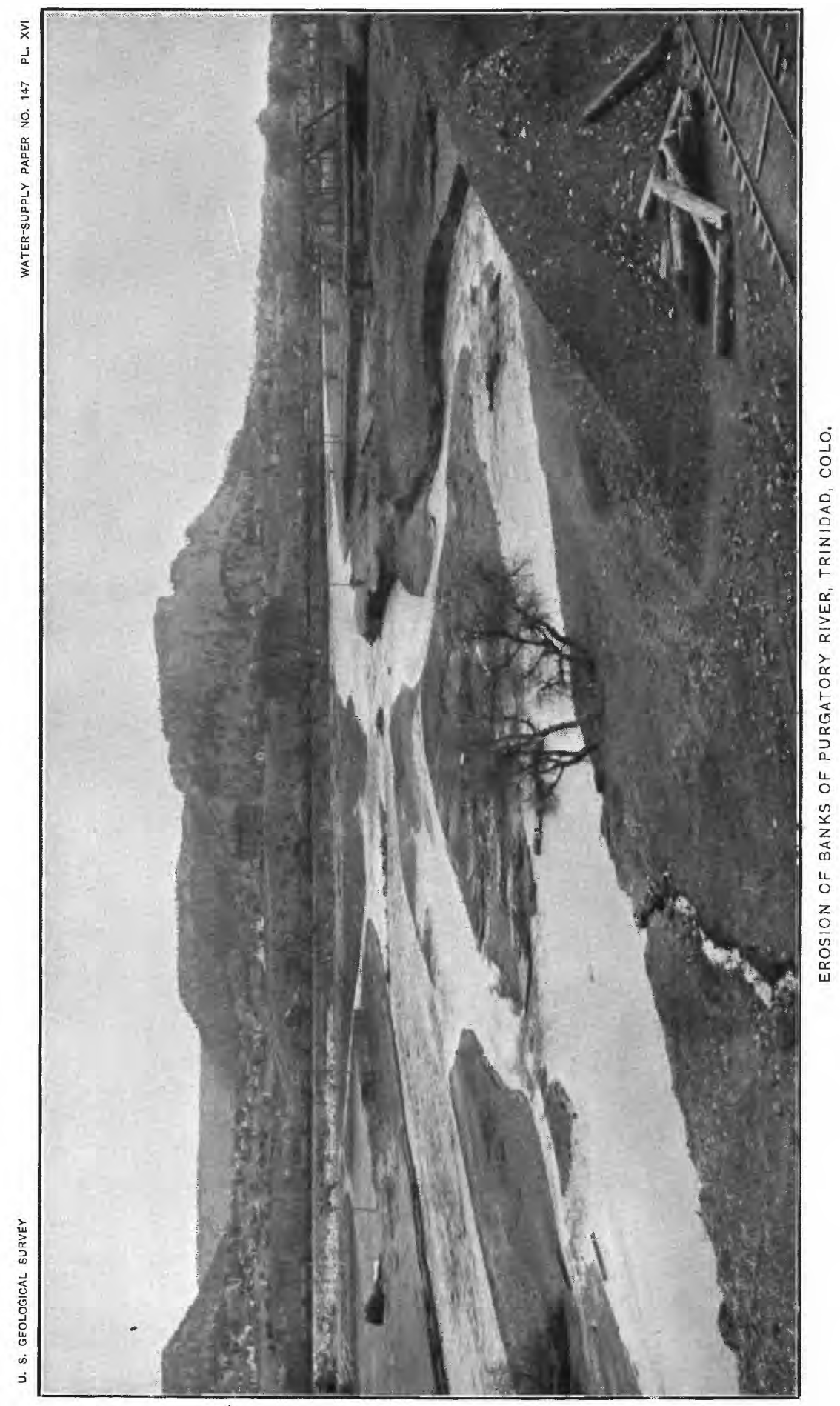


ages sustained. The loss to farmers in implements, crops, etc., is estimated at $\$ 25,000$.

Records in the possession of the Atchison, Topeka and Santa Fe Railway Company show that previous floods required approximately twenty-four hours to pass from Trinidad to Las Animas. The flood of October, 1904, passed over this distance in from nineteen to twenty hours. Fortunately there was only a small amount of water in the Arkansas above the mouth of the Purgatory; otherwise the flood of the lower Arkansas would have been much more destructive. The Santa Fe road from Holly to Las Animas was completely tied $u p$ for seven days.

The flood of October 1 was the greatest on record on this stream. Old residents declare that it was 2 feet greater than the flood of 1875 .

The following statements concerning the flood of 1875 are taken from the Las Animas Leader of September 18 and 25, 1875:

On September 16 a rush of water came down Purgatory River at Las Animas. Colo. The water was 5 feet higher than at any previous time that year. The Atchison, Topeka and Santa Fe Railway Company's tracks were under water for one-half mile on each side of the Purgatory, the bridge being 3 to 4 feet under water. At Fort Lyon the water was 4 feet higher than ever known before. The bottom land between the bridge and the post trader's (a distance of three-fourths of a mile) was a swift, raging flood. Up the Purgatory considerable damage was done, the greatest losses being of cord rood. stacked hay, cattle, fences, and adobe houses. The Arkansas above the mouth of the Purgatory was also in flood at this time, there heing reports of damage as far up as Pueblo. The Apishapa hrought in a large amount of this water, and the flood height was the highest in fifteen years.

PURGATORY FLOOD ON THE ARKANSAS.

Flood in Colorado.-On the Arkansas the lower bottom lands were entirely inundated from the month of Purgatory River to the Colorado-Kansas State line. As a flood at this season of the year was unexpected, both the Atchison, Topeka and Santa Fe Railway Company and the farmers were entirely unprepared for it, and the damage done was much greater than it otherwise would have been.

From Fort Lyon to Holly the water covered all the lower bottom lands, and from Caddoa to Lamar, where the bottom is narrower than above or below, the waters reached from bluff to bluff, a distance varying from three-fourths to 1 inile in width.

At the Colorado and Kansas canal dam, 1 mile east of Martin, the gate keeper was compelled to swim his horses out, so rapid was the rise of the water. 
At Powers the water was 3.5 feet deep on the level in places on each side of the Atchison, Topeka and Santa Fe Railwav, and the residents were compelled to take refuge on house tops and in trees. Hogs, bees, poultry, and cattle in large numbers were drowned, and thousands of tons of alfalfa were destroved by the water, which reached an average height of 3 feet on the stacks. The Amity canal dam, which is just below Powers, was damaged by the flood to the extent of $\$ 20,000$; the apron was practically off the dam at the time, and the terrific force of the current, augumented by the contracted river channel, had free access to the foundations, completely sweeping the dam away between crib No. 1 on the north and pier No. 2, a distance of 165 feet.

At Lamar, where the river channel is at the north of the town, the river was about $1 \frac{1}{2}$ miles in width. If it had risen another foot the town of Lamar would have been flooded. The damage in this vicinity was largely to alfalfa seed hay, which was stacked in the bottoms ready for thrashing, and to other forage and cattle.

The Salvation Army colony at Amity, located in a bottom level with the river, suffered more severely than any other settlement in the valley. The entire settlement was inundated and the total damage heavy.

Farther east the damage was small, as the river channel is a large shifting bed of sand, and the ranches are scattered and well back from the river.

All bridges over the Arkansas from the mouth of the Purgatory to Coolidge, Kans., inclusive, were badly damaged except the steel structure at Granada. The tracks of the Santa Fe, which parallel Arkansas River, were badly damaged. At the east end of the Las Animas-Santa Fe Railway Bridge across the Purgatory the flood cut away 400 feet of roadbed and earth bank, which was protected with stone riprap work placed on grillage. The overflow from the river channel carried $2 \frac{1}{2}$ miles of rail and ties off the embankment and badly damaged 2 additional miles of roadbed, cutting out the ballasting and the underlying embankment, although the track remained in place. This damage from overflow began a little west of Caddoa and extended to a point about 1 mile east of Powers, the greatest damage being done in the vicinity of Martin.

The Atchison, Topeka and Santa Fe Railway bridge across the Arkansas a short distance east of Byron was so badly damaged that about two-thirds of it had to be rebuilt.

The losses in Arkansas Valley in Colorado are estimated as follows: 
Damage by flood in Arkansas Talley, in Colorado, 1904.

Public property :

Repairs to bridges and roads from mouth of Purgatory to Colorado-

Kansas line estimated at

$\$ 50,000$

Private property :

Damages to meadow lands, fences, hay, cattle, etc 100,000 Corporation property :

Atchison, Topeka and Santa Fe Railway $\$ 75,000$

Dam and canals in valler 25,000

Total 100,000 250,000

There is a gaging station on Arkansas River, about 5 miles upstream from Powers, Colo., and about 1 mile east of Martin, at the dam used to divert the water of the Arkansas into the Colorado and Kansas Canal. During the flood the water reached a height of about 8.3 feet on its crest. An earth dike extending about 500 feet from its north end was washed away by the flood and about 185 feet of the crest so injured that its elevation on the left side was about 0.22 foot lower than before the flood. High-water marks of this flood were secured from lines on north and south abutments which were not entirely submerged. At the south abutment the floor reached 8.15 feet above the crest; on the north abutment, 8.9 feet. The greater height was probably due to the fact that the main current was near this end of the dam. On account of the irregularities in the crest of the dam, 8.3 feet is considered the maximum height of the flood. Mr. W. H. Houston, gate keeper, reports that the river began to rise about 12 o'clock midnight, continuing gradually until 5 a. m., at which time the water reached the floor of his house. The maximum stage was reached about 9 a. $\mathrm{m}$. and lasted about one hour. The river then began to recede and at $3 \mathrm{p} . \mathrm{m}$. the gage registered 4 feet.

The flood at this place reached from bluff to bluff, a distance of about 4,500 feet. It is difficult to calculate the discharge at this section on account of the large area of overflow and its varying slope and roughness of bed. The maximum discharge of the flood, computed by Kutter's formula, was found to be from 65,000 to 75,000 cubic feet per second; of this volume about 38,000 cubic feet passed over the dam and from 27,000 to 37,000 cubic feet on either side. In the computations of the volume of water passing around the dam the average slope of the river bed in this vicinity was assumed to be slightly less than that of the river channel, 0.001 being used. The coefficient of roughness $n$ varied from 0.030 to 0.040 . 
The gage height at this station during the flood and the corresponding discharge over the dam are as follows:

Gage height and discharge on Arkansas River at Colorado and Kansas Canal alam. September 29 to October 4. 190\%.

\begin{tabular}{|c|c|c|c|c|}
\hline \multirow{2}{*}{ Date. } & \multicolumn{3}{|c|}{ Height in feet. } & \multirow{2}{*}{$\begin{array}{l}\text { Discharge } \\
\text { in cubic } \\
\text { feet per } \\
\text { second. }\end{array}$} \\
\hline & 6 a. m. & 6 p. m. & Mean. & \\
\hline September 29 & 0.20 & 0.20 & 0.20 & $\ldots \ldots$ \\
\hline September 30 & 1.30 & 2.50 & 1.90 & 5,800 \\
\hline October $1 \ldots$ & 7.50 & 4.00 & 5.75 & 23,700 \\
\hline October $2 \ldots$ & 2.50 & 2.00 & 2.25 & T.200 \\
\hline October 3 & 1.90 & 1.80 & 1.85 & 5,600 \\
\hline \multirow{3}{*}{$\begin{array}{c}\text { October } 4 . . . \\
\text { Total .. }\end{array}$} & 1.00 & .80 & .90 & 1,700 \\
\hline & & & & 44,000 \\
\hline & & & & 8,800 \\
\hline
\end{tabular}

The discharge of the streams from September 30 to October 4 , inclusive, as computed from the above gage heights, was 87,296 acrefeet passing over the dam and 22,000 acre-feet passing around the dam; total, 109,300 acre-feet.

The increase of flow at this place to twice that at Trinidad was due to the water from the drainage of southern tributaries entering below Trinidad, large volumes entering from Rule, Caddoa, and Muddy creeks. There was practically no storage of any of this water.

Flood in Kansas.-The flood, as it moved down Arkansas River, was gradually absorbed by the sandy bed and banks, being thus considerably reduced in volume and destructiveness. The highway bridges at Hartland, Lincoln, Ingalls, Garden, Dodge, and Kinsley were damaged, short sections of these bridges in most cases being carried out. Very little damage was done to crops along the river, as it did not overflow in cultivated portions of the valley.

The following table gives the mean daily gage height and corresponding discharge, of the river at Syracuse, Dodge, Hutchinson, and Arkansas City during this flood, also the total volume of this flood at these places: 
Gage height and discharge of Arkansas River in Kansas. October 1 to 15, 1904.

\begin{tabular}{|c|c|c|c|c|c|c|c|c|}
\hline \multirow[b]{2}{*}{ Date. } & \multicolumn{2}{|c|}{ Syracuse. } & \multicolumn{2}{|c|}{ Dodge City. } & \multicolumn{2}{|c|}{ Hutchinson. } & \multicolumn{2}{|c|}{ Arkansas City. } \\
\hline & $\begin{array}{c}\text { Mean } \\
\text { gage } \\
\text { neight } \\
\text { in feet. }\end{array}$ & $\begin{array}{c}\text { Dis- } \\
\text { eharge } \\
\text { in second- } \\
\text { feet. }\end{array}$ & $\begin{array}{c}\text { Mean } \\
\text { gage } \\
\text { height } \\
\text { in feet. }\end{array}$ & $\begin{array}{c}\text { Dis- } \\
\text { charge } \\
\text { in second- } \\
\text { feet. }\end{array}$ & $\begin{array}{c}\text { Mean } \\
\text { gage } \\
\text { height } \\
\text { in feet. }\end{array}$ & $\begin{array}{c}\text { Dis- } \\
\text { charge } \\
\text { in second- } \\
\text { feet. }\end{array}$ & $\begin{array}{c}\text { Mean } \\
\text { gage } \\
\text { height } \\
\text { in feet. }\end{array}$ & $\begin{array}{l}\text { Dis- } \\
\text { charge } \\
\text { in second- } \\
\text { feet. }\end{array}$ \\
\hline October 1 & 6.75 & 18,690 & & & & & & \\
\hline October $2 \ldots$ & 7.00 & 21,300 & 6. 75 & 15,010 & & $\cdots$ & & \\
\hline October:3.. & 5. 70 & 10,610 & 6.25 & 13,175 & 3.20 & 2,500 & & \\
\hline October 4 & 4. 70 & 4,575 & 4.50 & 7.125 & 4.80 & 8,000 & & \\
\hline October $\tilde{5}$ & 3.80 & 1,250 & 3.90 & 5,085 & 3.90 & 4,425 & & ...... \\
\hline October 6 & 3.70 & 1,075 & 3.40 & 3,625 & 4.30 & 5,965 & 7.30 & 5,400 \\
\hline October 7 & 3.70 & 1,075 & 2.85 & 2,220 & 3.90 & 4,425 & 6.90 & 4,590 \\
\hline October 8 & 3.50 & 785 & 2.40 & 1,325 & 3.65 & 3.695 & 6.50 & 3.850 \\
\hline October 9 & 3.50 & 785 & 2.25 & 1,120 & 3.50 & 3,275 & 6. 20 & 3,350 \\
\hline October 10 & 3.50 & 785 & 2.20 & 1,050 & 3.25 & 2,625 & 5.80 & 2,725 \\
\hline October 11 & & & 2.10 & 910 & 3.30 & 2,750 & 5.30 & 2.075 \\
\hline October 12 & & & & & 2.60 & 1,300 & 5.10 & 1,835 \\
\hline October 13 & & & & & & & 4.90 & 1,610 \\
\hline October 14 & & & & & & & 4.60 & 1,300 \\
\hline October 15 & & & & & & & 4.40 & 1,125 \\
\hline Total & & 60,930 & & 50,645 & & 38,960 & & 27,860 \\
\hline Mean flow for & 10 days & 6,093 & & 5,064 & & 3,896 & & 2,786 \\
\hline Acre-feet for & 10 days & 120,824 & & 100,419 & & 77.258 & & 55,246 \\
\hline
\end{tabular}

Of the 120,824 acre-feet that passed Syracuse, Kans., only 55,246 acre-feet reached the southern border of Kansas at Arkansas City. Hence more than half the entire flood volume was absorbed in its passage through Kansas.

Dumage.-The total damage caused by the flood in Colorado and Kansas will approximate closely $\$ 650,000$.

\section{LA PLATA RIVER FLOOD, COLORADO.}

On October 6, 1904, a storm occurred on La Plata River, a tributary of the San Juan, that caused the greatest flood along the middle and lower part of this valley since 1882. This stream and the storm area are shown in fig. 17. In the vicinity of the mouth of the La Plata the storm began at about $1 \mathrm{p}$. $\mathrm{m}$. October 6 , traveling very rapidly up Jewett Valley through the "Meadows," reaching Navajo Springs at 1.15 p. m. and La Plata and Pendleton at 1.30 p. m., in- 
creasing in fury as it went north. At Pendleton from 1.30 to $3 \mathrm{p} . \mathrm{m}$. the storm was at its height, the rain coming down in very heavy gusts at intervals of about ten minutes, and at 2 o'clock and thereafter accompanied by heavy hailstones, which accumulated at various places to a depth of 8 inches. During those two hours the precipitation was about 1 inch.

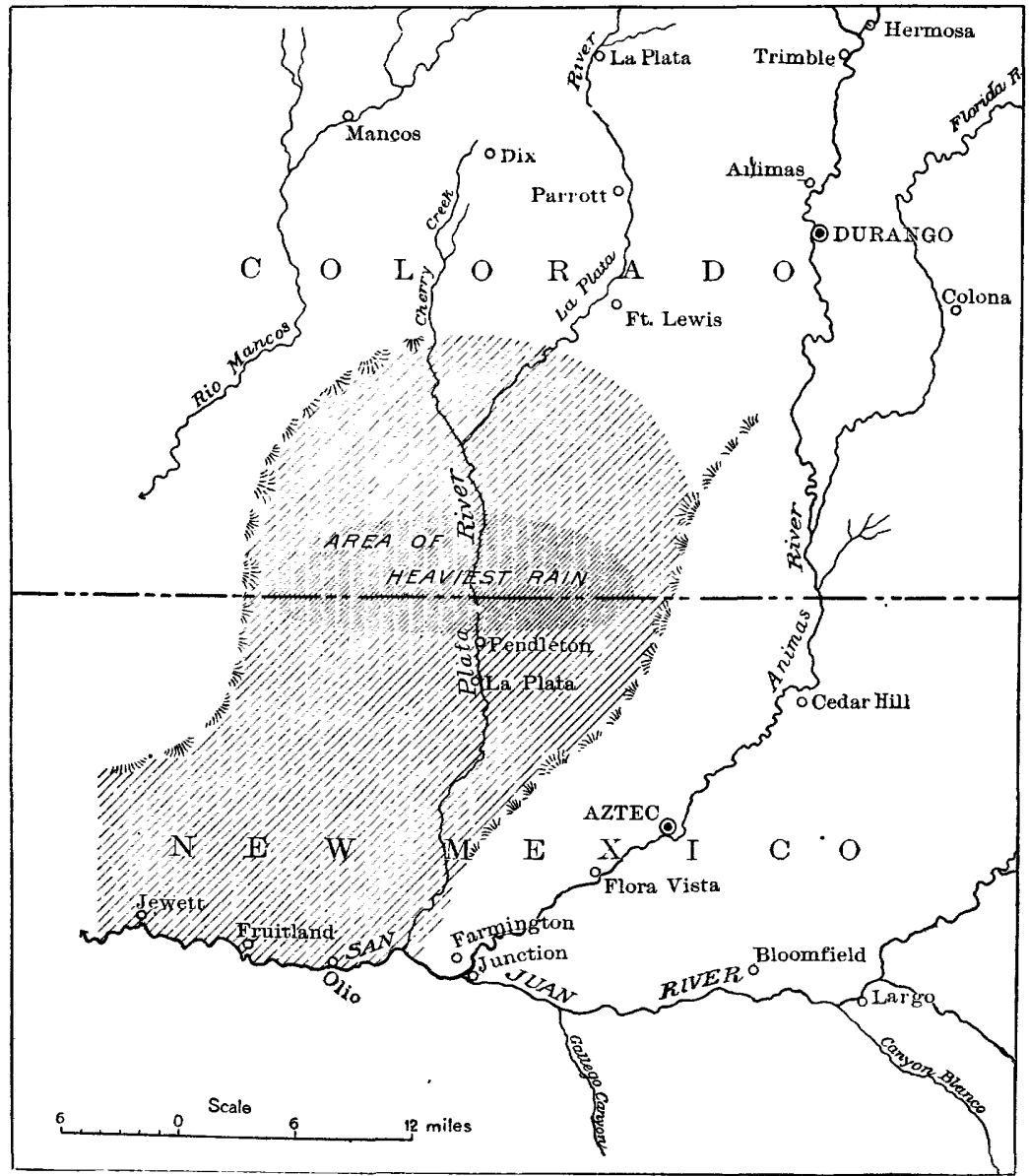

FIG. 17.-Drainage basin of La Plata River and area of heaviest rainfall on october 8 , 1904 .

The heavy shope of the valley, combined with a large amount of runoff, caused the river to begin to rise very rapidly at $3 \mathrm{p} . \mathrm{m}$. It continned to rise and fall several feet in half an hour, as the canyons above discharged their water. At $\pm \mathrm{p}$. $\mathrm{m}$. it had reached its maximum stage at Pendleton, passing over the floor of the highway bridge at a depth of 2 feet. At 5 o'clock the rain ceased except for a light 
drizzle, and the river fell very rapidly until $\tau$ p. m., when another heavy shower fed the river and in about fifteen minutes caused it to rise to the approaches of the bridge. This shower continued for about two hours, when it moderated and settled into a steady rain that lasted until 4 o'clock the following morning. On Friday, October 7 , there were no heavy rains, but a light drizzle fell until the evening, when another shower occurred lasting about four hours. At this time the fury of the storm had spent itself, although in some localities in the northern part of the valley there were unimportant light rains on October 8.

The river remained at an extremely high stage for two hours, and was at flood stage for thirty-six hours after the beginning of the storm.

The maximum discharge of this stream near Pendleton was computed by Mr. Tobish from Kutter's formula. The natural width of the channel at this place is about 30 feet, but the water overflowed the banks and had a width of 265 feet. The bed proper is composed of bowlders and stone, but the overflow portion of the section is thickly covered with willows. The slope was found to be 0.0052 , the area 1,176 , and wetted perimeter 280 . From these data and the value of $n=0.010$, the mean velocity was found to be $\tau$ feet per second and the maximum discharge 8,232 cubic feet per second. The discharge was also measured at three other places along the stream, but the channel conditions were so unsatisfactory that the results were not considered reliable.

Much damage was done in various ways by the storm, the hail destroying the fruit crop, which was nearly ready for market, and the flood damaging to a considerable extent the reservoirs and irrigation ditches. It is claimed by some, however, that the benefits derived from the irrigation of the farms along the river will nearly offset the damage done to the fruit. The estimated damage in the valley to orchards, crops, and alfalfa seed is about $\$ 7,500$.

The greatest damage done by the storm was to the reservoirs and irrigation ditches, all the former, excepting the Johnson and Conger reservoirs, being destroyed. This destruction of the reservoirs is believed to have been due almost entirely to faulty construction, the foundation for the reservoir walls not having been properly prepared and the walls themselves not having been properly constructed, the earth being merely dumped in place without being wetted or packed. Another cause of failure was the fact that little or no attention had been given to the proper size of the spillways.

Sixteen irrigating ditches, having lengths varying from 1 to 7 miles, were damaged by amounts varying from $\$ 50$ to $\$ 750$ each, the total esitimated damage to ditches alone being $\$ 2,850$. 


\section{FLOODS DUE TO FAILURE OF DAMS AND RESERVOIR WALLS.}

By E. C. MURPhy.

\section{GENERAL STATEMENT.}

Floods of this character during the past year have been quite numerous, but the only one that can be described in this paper is the failure of an earth dam near Scottclale, Pa. Description or mention of failure of other similar structures during the year may be found in engineering journals. ${ }^{a}$

\section{SCOTTDALE FLOOD.}

The Scottdale Valley flood, which occurred July 7,1904 , was due to the failure of an earth dam situated on Jacobs Creek, a few miles above Scottdale, Pa. This creek rises in western Pennsylvania, flows southwest and west a distance of about 25 miles, and empties into Youghiogheny River about 18 miles southeast of McKeesport, Pa.

The dam was 70 feet high, had a top width of 12 feet, a puddle eore, and both faces paved with stone. It was built in 1901 and was owned by the Citizens' Water Company and used to form a reservoir to supply Scottdale and neighboring places with water. The dam failed, as shown in Pl. XV, $B$ (p. 162), by the washing out of a $V$-shaped piece at the right end. This piece was about 100 feet wide at the top and 15 feet wide near the base. The water did not overflow the bank-in fact, it was several feet below the crest of the dam at the time of failure. A leak was noticed a considerable time before the break occurred, but efforts to stop it were unavailing. It increased until a well-defined break was discovered near the base of the dam. Failure immediately followed, liberating about 2,000,000 gallons of water. The loss caused was small on account of the sparsely settled condition of the vallev, consisting mainly in damage to machinery in the pump house just below the dam, the washing away of reveral small bridges along the stream, and some damage to a few buildings along the creek.

The failure of this dam was due to leakage between the end of the dam and the rock side of the valley. This rock was of a shaly nature, the seams dipping $5^{\circ}$ to $6^{\circ}$ downstream. The earth probably settled, leaving a crack between itself and the rock. This explanation appears quite plausible from the fact that on September 14, when the writer visited the dam, there was a leak under it near the left bank that was passing more water than the natural flow of the stream. The water thus leaking under the dam was being

${ }^{a}$ For Winston, N. C., reservoir failure ser: Eng. News, vol. 53, 1904, p. 444. 
pumped back into the reservoir. An attempt had been made to stop this leak by a cut-off wall, but it had apparently resulted in failure. The upstream face of several hundred feet of the part of the dam that did not completely fail slipped down toward the water, a distance of from 1 to 3 feet, leaving cracks of from 1 to 4 inches in width.

The dam was immediately rebuilt, and precaution was taken to prevent the water from passing around the end of the dam by building a masonry wall into the rock of the hillside and extending it out into the core of the dam. It is quite evident that a sufficient amount of care was not taken in constructing the dam to prevent leakage underneath and around the ends.

\section{DROUGHT IN OHIO RIVER DRAINAGE BASIN.}

By E. C. Murphy.

\section{INTRODUCTION.}

The severe drought of 1904 in the Ohio drainage basin and in the Southern and New England States calls attention to the fact that not only in the arid West may there be a shortage of rainfall, and consequently of water supply, but that such conditions may occur east of the Mississippi also, and brings prominently to view the necessity for abundant storage of flood waters. Fortunately the 1904 drought came near the end of the growing season and did not cause a severe shortage of crops, though it seriously affected manufacturing, railway, and navigation interests in the Ohio drainage basin.

The nor'mal monthly distribution of rainfall over the United States varies greatly. On the Pacific coast the winter months are wet, the summer months are dry; on the Great Plains the reverse is true-the summers are comparatively wet and the winters dry. East of the Mississippi the precipitation during the winter montlus is generally about the same as during the summer months, but there are great variations from the normal rainfall. The areas of low and high precipitation are frequently comparatively small. In a few hours' ride on the train one will often see a marked change in the vegetation, due to the amount of moisture in the soil, this being especially true in the Great Plains region. Short periods of diminished rainfall are common east of the Mississippi; west of the Mississippi they are more frequent and of longer duration.

\section{STREAMS AND DRAINAGE BASIN.}

The drainage basin of the Ohio (see Pl. XVII) is the second in size of those forming the great Mississippi drainage basin. It has a length of about 660 miles, a width of 480 miles, and an area of about 
214,000 square miles. Its northern boundary extends to about 50 miles from Lake Erie and has an elevation of from 500 to 1,000 feet above sea level; the eastern and sonthern boundaries lie along the crest of the Allegheny Mountains for from 700 to 800 miles. The greater portion of the watershed south of the Ohio is rough, with steep, uncultivated slopes, much of which is heavily timbered. The streams from this mountainous portion have a steep slope and are subject to great and sudden fluctuations in volume. Chief of these are the Tennessee, Cumberland, Kentucky, Big Sandy, Great and Little Kanawha, and Monongahela. North of the Ohio the country consists of gently rolling cultivated land, with little timber except in the eastern portion of the basin, which is mountainous and resembles the part south of the Ohio. The Wabash, Miami, Scioto, and Muskingum, are the principal tributaries from the northern part of the basin. Their

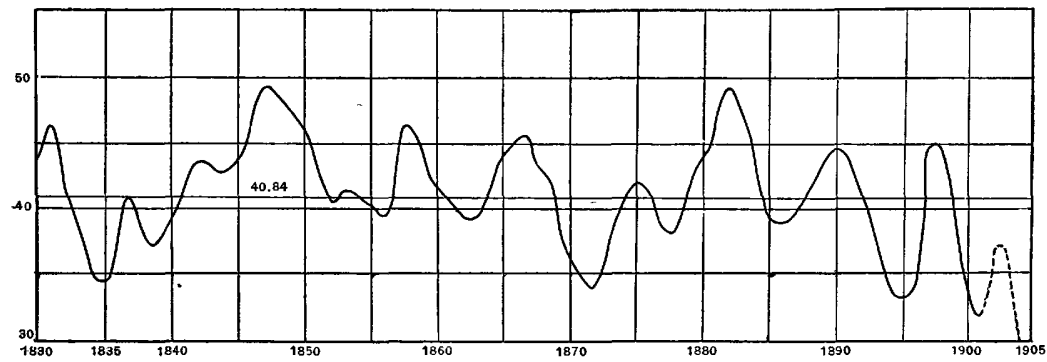

FIG. 18.-Curve showing mean annual precipitation at three places in the Ohio River drainage basin from 1830 to 1904 .

flow is very different in character from the southern tributaries, being less rapid and more nearly uniform.

\section{PRECIPITATION.}

The annual precipitation over the basin may be said to vary from about 35 to 45 inches. The mean of the annual precipitation at Marietta, Portsmouth, and Cincinnati from 1830 to 1904 is shown in fig. 18, in which the curve shows the variation in precipitation from year to year. The years 1835, 1871, 1895, 1901, and 1901 were years of small precipitation, each being less than the preceding one. The years $1831,1847,1858$, and 1882 were years of excessive rainfall. The extreme variations from the mean are 8.7 inches in 1847 and 11.3 inches in 1904. The extreme variation from the mean is larger, as a rule, for a single place than for the mean of three or more places, so that the variations from the mean for the whole drainage basin for a long period are smaller than the variations at any one place in this basin for the same length of time.

The period from 1893 to 1896 was very dry, and stages of the water 


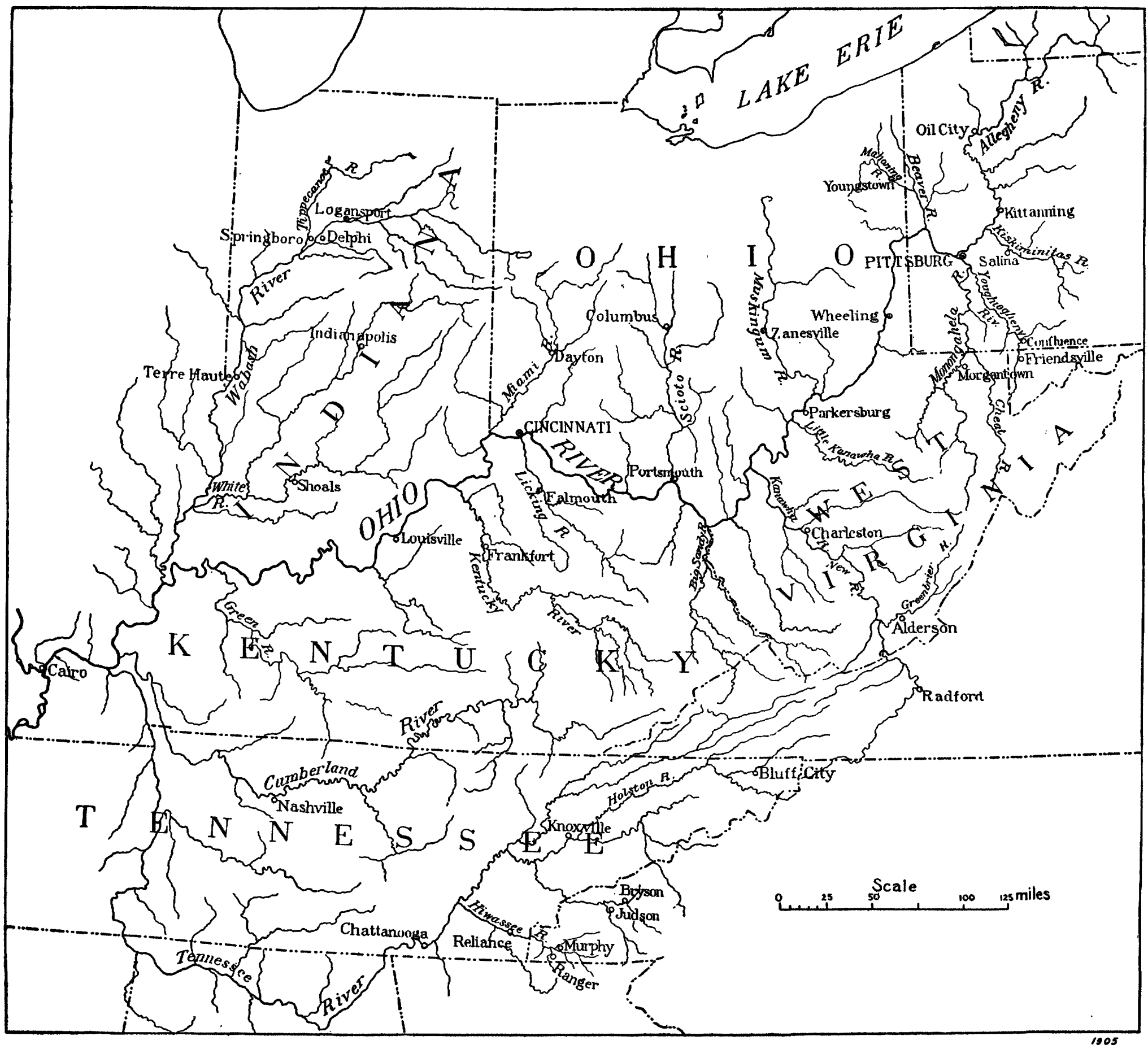

DRAINAGE BASIN OF OHIO RIVER. 
along the Ohio are usually referred to the low water of 1895 . It will be interesting to compare the precipitation and stream stages from 1893 to 1896 with those from 1899 to 1904 for places north of the Ohio and also south of or on it. The places selected for this comparison and the annual precipitation at each for these periods are given below.

Innual precipitation, in inches, at places in ohio River drainage basin.

\begin{tabular}{|c|c|c|c|c|c|c|c|c|c|}
\hline Place. & 1893. & 1894. & 1895. & 1896. & 1900. & 1901. & 1902. & 1903. & 1904. \\
\hline Oil City, $\mathrm{Pa}$. & 49.97 & 34.32 & 40.81 & 40.97 & 37.83 & 47.49 & 45.54 & 48.90 & 41.71 \\
\hline Dayton, Ohio & 38.93 & 26.79 & 25.89 & 32.25 & 33.86 & 26.05 & 35.97 & 38.69 & 37.19 \\
\hline Terre Haute, Ind.. & 39.61 & 29.12 & 32.50 & 37.27 & $39.4 \%$ & 31. 78 & 34.88 & 33.22 & 39.27 \\
\hline Mean. . & 42.84 & 30.08 & $33.0 \%$ & 36.83 & $3 \pi .05$ & 35.11 & 38.80 & 40.27 & 39.39 \\
\hline Mean.. & \multicolumn{4}{|c|}{ 35. 70} & \multicolumn{5}{|c|}{38.12} \\
\hline Confluence, $\mathrm{Pa}$ & 43.39 & 42.14 & 35.11 & 50.22 & 44.03 & 41.17 & 45.92 & $3 \% .12$ & 31.38 \\
\hline Charleston, W. Va - & 41.10 & 32.73 & 32.26 & 44.72 & 40.20 & 45.94 & 45.37 & 38.40 & ..... \\
\hline Falmouth, Ky ... & 41. 45 & 26.30 & 29.84 & 39.59 & 40.53 & 29.82 & 40.76 & 37.46 & 32.33 \\
\hline Cincinnati, Ohio.. & 44.00 & 26.59 & 29.33 & 34.48 & 27.78 & 17.99 & 37.30 & 34.69 & 29.54 \\
\hline \multirow{2}{*}{$\begin{array}{c}\text { Louisville, Ky } \\
\text { Mean }\end{array}$} & 43.93 & 38.08 & 38.86 & 48.22 & 38.04 & 29.53 & 41.65 & 33.69 & 29.25 \\
\hline & $42.7 \gamma$ & $33.1 \%$ & 33.08 & 43.45 & 38.12 & 32.89 & 42.20 & $36.2 \pi$ & 30.62 \\
\hline Mean & 42.80 & 32.01 & 33.75 & 40.97 & $3 \pi .72$ & 33.72 & 40.92 & 37.77 & 34.38 \\
\hline Mean.. & \multicolumn{4}{|c|}{$3 \pi .21$} & \multicolumn{5}{|c|}{36.90} \\
\hline
\end{tabular}

It appears from this table that the mean precipitation for the period 1893-1896 for these eight places is 0.3 inch greater than for the perior $1899-1904$.

The mean of the three places north of the river is 1.51 inches less than the mean for the five places south of or on it for the first period (1893-1896) and 1.22 inches greater than for the second period-that is, the drought was more severe north of the Ohio from 1893 to 1896 than south of it, and the opposite for the period 1899 to 1904 .

The table below gives the monthly precipitation at each of these eight places and the monthly variation from the normal at some of them for two years of the first period and three years of the second period. Monthly precipitation, in inches, and variation from normal at places in ohio River arainage basin.

OIL CITY, PA.

[P., precipitation; V., variation from normal.]

\begin{tabular}{|c|c|c|c|c|c|c|c|c|c|c|c|c|c|}
\hline Year. & Jan. & Feb. & Mar. & Apr. & May. & June. & July. & Aug. & Sept. & Oct. & Nov. & Dec. & $\begin{array}{c}\text { An- } \\
\text { nual. }\end{array}$ \\
\hline $1894(\mathrm{P}$ & 3.48 & 2.94 & 1.90 & 3.17 & 5.04 & 1.62 & 1.95 & 0.41 & 6.51 & 2.43 & 2.22 & 2. 65 & 34.32 \\
\hline 1895 (P.) & 4.63 & 1.49 & 1.64 & 2.68 & 4. 22 & 2.58 & 3.65 & 3.09 & 5.15 & 1.24 & 5.11 & 5. 32 & 40.80 \\
\hline 1901 (P.) & 2.55 & 1. 76 & 4. 34 & 5.99 & 5.14 & 5.37 & 3.42 & 4.11 & 6.61 & 6.39 & 3.96 & 4. 31 & 47.95 \\
\hline 1903 (P & 3.82 & 5.07 & 5.06 & 3.44 & 2.62 & 7.08 & $\tau .04$ & 4. 32 & 2.04 & 2.92 & 2.67 & $2.82^{\prime}$ & 48.90 \\
\hline 1903 (V.). & +.58 & +1.79 & +1.81 & .67 & -1.31 & +2.32 & +2.49 & +1.42 & -1.65 & +.38 & -.89 & -.42 & +7.19 \\
\hline 1904 (P.)... & 5.45 & 3.51 & 6.10 & 4.50 & 4.39 & 2.30 & 3.42 & 4.02 & 9.66 & 1. 64 & & $2.80^{\circ}$ & 41. .1 \\
\hline
\end{tabular}


Monthly precipitation, in inches, and variation from normal. etc.-Continued.

DAYTON, OHIO.

\begin{tabular}{|c|c|c|c|c|c|c|c|c|c|c|c|c|c|}
\hline Year. & Jan. & Feb. & Mar. & Apr. & May. & June. & July. & Aug. & Sept. & Oct. & Nov. & Dec. & $\begin{array}{c}\text { An- } \\
\text { nual. }\end{array}$ \\
\hline 1894 (P.) & 2.33 & 3. 79 & $2.5 \%$ & $1.67^{\circ}$ & 3.90 & 2.05 & 0.42 & 2.63 & 1.53 & 0.90 & 1.81 & 3.19 & 26.79 \\
\hline $1895(\mathrm{P})$ & 4.08 & .18 & 1.35 & 1.80 & 1.51 & 3.43 & .74 & 2.25 & .66 & .80 & 5.93 & 3.16 & 25.89 \\
\hline $1901\left\{\begin{array}{l}(\mathrm{P} .) \\
\mathrm{V} .1\end{array}\right.$ & $\begin{array}{r}2.00 \\
-1.06\end{array}$ & $\begin{array}{r}1.33 \\
-1.86\end{array}$ & $\begin{array}{r}2.42 \\
-.85\end{array}$ & $\begin{array}{r}1.87 \\
-1.06\end{array}$ & $\begin{array}{r}3.45 \\
-\quad .39\end{array}$ & $\begin{array}{r}4.04 \\
+1.08\end{array}$ & $\begin{array}{r}1.33 \\
-1.59\end{array}$ & $\begin{array}{r}.91 \\
-2.08\end{array}$ & $\begin{array}{r}2.32 \\
-\quad .38\end{array}$ & $\mid \begin{array}{r}1.12 \\
-\quad .91\end{array}$ & $\begin{array}{r}1.43 \\
-1.96\end{array}$ & $\begin{array}{r}3.83 \\
+1.32\end{array}$ & $\begin{array}{r}26.05 \\
-\quad 9.69\end{array}$ \\
\hline $1903\left\{\begin{array}{l}(\mathrm{P} .) \\
(\mathrm{V} .)\end{array}\right.$ & $\begin{array}{r}2.39 \\
-\quad .64\end{array}$ & $\begin{array}{r}4.79 \\
+1.60\end{array}$ & $\begin{array}{r}3.69 \\
+\quad .42\end{array}$ & $\begin{array}{r}3.66 \\
+\quad .86\end{array}$ & $\begin{array}{r}4.66 \\
+\quad .03\end{array}$ & $\begin{array}{r}9.09 \\
+4.83\end{array}$ & $\begin{array}{r}1.43 \\
-1.46\end{array}$ & $\begin{array}{r}1.17 \\
-1.56\end{array}$ & $\begin{array}{r}.65 \\
-1.95\end{array}$ & $\begin{array}{r}2.79 \\
+\quad .48\end{array}$ & $\begin{array}{r}2.44 \\
-.79\end{array}$ & $\begin{array}{r}2.00 \\
-\quad .64\end{array}$ & $\begin{array}{r}38.69 \\
+\quad 2.05\end{array}$ \\
\hline $1904($ P.) & $\begin{array}{r}4.61 \\
+1.55\end{array}$ & 2.53 & $\begin{array}{r}7.90 \\
+4.63\end{array}$ & $\begin{array}{r}3.18 \\
+\quad .38\end{array}$ & 4.05 & $\begin{array}{r}2.47 \\
-1.79\end{array}$ & $\begin{array}{r}3.04 \\
+\quad .15\end{array}$ & $\begin{array}{r}1.87 \\
-.86\end{array}$ & $\begin{array}{r}2.00 \\
-\quad .60\end{array}$ & $\begin{array}{r}1.83 \\
-1.01\end{array}$ & $\begin{array}{r}.63 \\
-2.60\end{array}$ & $\begin{array}{r}3.68 \\
+1.0 a\end{array}$ & $\begin{array}{r}37.19 \\
+\quad .5\end{array}$ \\
\hline
\end{tabular}

TERRE HATTE, INl).

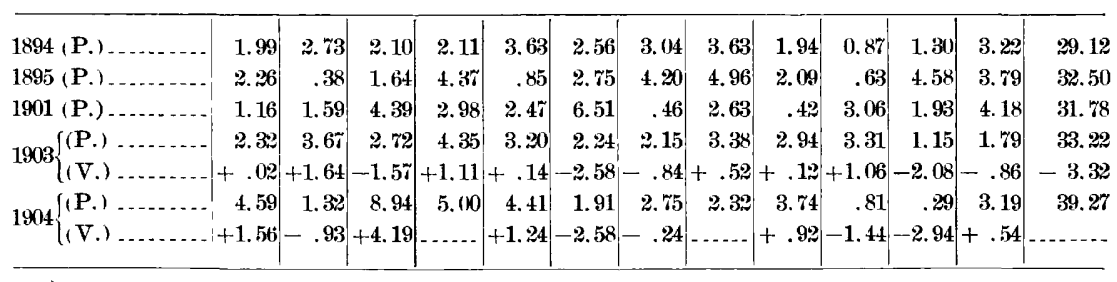

CONFLUENCE, PA.

\begin{tabular}{|c|c|c|c|c|c|c|c|c|c|c|c|c|c|}
\hline 1894 (P.) $\ldots \ldots$ & 3.15 & 3.57 & 2.36 & 4.94 & 5.86 & 2.90 & 3.00 & 1.37 & 3.48 & 2.71 & 2.87 & 5,93 & 42.14 \\
\hline 1895 (P.) & 2.98 & 1.43 & 4.03 & $3.5 \%$ & 1.94 & 4.28 & 6.18 & 3.75 & .68 & .67 & 3.02 & 2.58 & 35. 11 \\
\hline 1901 (P.) $\ldots$ & $\$ .91$ & 1. 35 & 4.35 & 5.86 & $6.3 \%$ & 1.99 & 3.55 & $4.0 \%$ & 2. 49 & .85 & 2.88 & 4.65 & 41.17 \\
\hline $1903^{\int(P .)}$ & 4.46 & 1.98 & 2.93 & 3.00 & 3.16 & 3. 74 & 5.90 & 3.22 & 1.64 & 2.64 & 2.91 & 1.54 & 37.12 \\
\hline $805\{$ (V.). & +.63 & -1.79 & -1.05 & -.44 & -.96 & -.50 & +.67 & -.29 & -1.48 & -.22 & -.49 & -1.99 & -7.91 \\
\hline 1904 (P.) & 2.87 & 2.66 & 4. 18 & 3. 20 & 4.03 & 1. 62 & 2.34 & 4.08 & 1.20 & 1.53 & 43 & 3.24 & 31.38 \\
\hline
\end{tabular}

CHARLESTON, W. VA.

\begin{tabular}{|c|c|c|c|c|c|c|c|c|c|c|c|c|c|}
\hline 1894 (P.) & 2.35 & 4.57 & 1.94 & 3.06 & 3.52 & 2.86 & 0.66 & 2.05 & $3.7 \%$ & 1.65 & 2.39 & 3.91 & 32.73 \\
\hline 1895 (P.) . & 5. 19 & 69 & $3.87^{6}$ & 2.60 & 2.08 & 1.83 & 4.19 & 4.81 & 1.05 & .72 & 2.54 & \&. 69 & 32.96 \\
\hline 1901 (P.) . . . & 2.10 & .32 & 3.36 & 6.85 & 5.40 & 6.92 & 2.08 & 5.00 & 3.57 & .70 & 2.23 & 7.41 & 45.94 \\
\hline $1009^{\int(P .)}$. & 2.52 & 6.36 & 4.56 & 5.95 & 1.83 & 4.21 & 2.76 & 1.93 & .57 & 3.43 & 2.16 & 2.12 & 34.40 \\
\hline${ }^{1905}\left\{(\mathrm{~V} .)_{-}\right.$ & $-1.0 r$ & +2.83 & +.22 & +2.54 & -2.20 & -.58 & -1.03 & -2.69 & -1.89 & +1.51 & -1.21 & $-1.8 \mathrm{x}$ & -4.65 \\
\hline 1904 (P.) ... & 1.68 & 2.63 & 3.54 & 4.08 & 2.72 & 2.69 & 3.28 & 3.45 & & 1.65 & .45 & $\because 61$ & \\
\hline
\end{tabular}

FALMOUTH, KY.

\begin{tabular}{|c|c|c|c|c|c|c|c|c|c|c|c|c|c|}
\hline 1894 (P.) & 2.92 & 3.09 & 2.50 & 3.20 & 3.08 & 1.62 & 0.74 & 1.88 & 1.46 & 1.47 & 0.72 & 3.67 & 26.30 \\
\hline 1895 (P.) . . . . . & 5.62 & .58 & 1.73 & 2.70 & 2.18 & 2.46 & 4.06 & 1.13 & .49 & .84 & 3.34 & 4.71 & 29.84 \\
\hline 1901 (P.) & 1.01 & 1.68 & 2.60 & 3.67 & 3.03 & 3.68 & 2.34 & 2.74 & 2.02 & .84 & 1.46 & 4.75 & 29.82 \\
\hline $190 \int^{\int(\text { P. }) \ldots .}$ & $2.47^{\prime \prime}$ & 7.25 & 3.47 & 4.35 & 2.22 & 2.78 & 2.65 & 4.36 & 1.30 & 2.20 & 2.04 & 2.37 & 37.46 \\
\hline${ }^{1500}\left(V_{\text {. }}\right) \ldots$ & -1.28 & +3.81 & -.34 & +1.06 & -1.27 & -1.31 & -1.04 & +1.24 & -.64 & -.03 & -1.08 & -.60 & -2.38 \\
\hline $1904\left\{\begin{array}{l}(\mathrm{P} .) \\
(\mathrm{V} .)\end{array}\right.$ & $\begin{array}{r}2.88 \\
-\quad .82\end{array}$ & $\begin{array}{r}2.63 \\
-\end{array}$ & $\begin{array}{r}1.62 \\
+3.58\end{array}$ & $\begin{array}{r}3.00 \\
-\ldots\end{array}$ & $\begin{array}{r}1.92 \\
-1.37\end{array}$ & $\begin{array}{r}3.96 \\
-.13\end{array}$ & $\begin{array}{r}0.96 \\
-2.55\end{array}$ & $\begin{array}{r}2.20 \\
-2 .-\end{array}$ & $\begin{array}{r}1.69 \\
-\quad .24\end{array}$ & $\begin{array}{r}.67 \\
-1.47\end{array}$ & $\begin{array}{r}.75 \\
-3.06 \\
\end{array}$ & $\begin{array}{r}4.05 \\
-. .--\end{array}$ & $\begin{array}{r}32.33 \\
\ldots .\end{array}$ \\
\hline
\end{tabular}

a Approximate. 
Monthly precipitation, in inches, and departure from normal, etc.-Continued. CINCINNATI, OHIO.

\begin{tabular}{|c|c|c|c|c|c|c|c|c|c|c|c|c|c|}
\hline Date. & Jan. & Feb. & Mar. & Apr. & May. & June. & July. & Aug. & Sept. & Oct. & Nov. & Dec. & $\underset{\text { nual. }}{\text { An- }}$ \\
\hline 1894 (P.) & 2.75 & 3.78 & 2.36 & 1.60 & 2.35 & 4.17 & 0.13 & 1.98 & 2.48 & 0.82 & 0.98 & 3.23 & 26. 59 \\
\hline 1895 (P.) & 6.13 & .37 & 1.51 & 2.68 & 1.82 & 2.15 & 2.27 & 3.29 & .49 & .73 & 4.66 & 3.29 & 29.33 \\
\hline $1901\{(\mathrm{P})$. & .87 & 1.35 & 2.01 & 1.93 & 1.62 & 2.97 & 1.44 & .88 & .92 & .59 & .74 & 3.37 & 17.99 \\
\hline${ }^{1001}\{(\mathrm{~V}$. & -2.51 & -2.17 & -1.60 & $9-.95$ & -1.70 & -1.69 & -2.05 & -2.66 & -1.43 & -1.68 & -2.59 & +.41 & -20.52 \\
\hline $1903^{\prime(P .)}$ & 2.05 & 5.76 & 4.97 & 3.49 & 3.83 & $3.2 \pi$ & 2.31 & 2.75 & 1.78 & 1.31 & 1.45 & 1.72 & 34.69 \\
\hline${ }^{1000}\{(\mathrm{~V}) .$. & -1.4 & +2.1 & +1.7 & +.3 & +.4 & -1.1 & -1.1 & -1.0 & -.6 & -1.1 & -1.8 & -1.4 & -5.18 \\
\hline $1904\{(\mathrm{P})$. & 2.66 & 2.66 & 8.17 & 2.28 & 3.70 & 2.60 & .80 & .41 & 1.28 & .89 & .34 & 3. 75 & 29.54 \\
\hline${ }^{\perp E 0 \pm}\{(\mathrm{V})$. & -.8 & -1.2 & +4.9 & -.9 & +.3 & -1.8 & -2.6 & -3.3 & -1.14 & -1.55 & -2.96 & +.63 & -10.5 \\
\hline
\end{tabular}

LOUISVILLE, KY.

\begin{tabular}{|c|c|c|c|c|c|c|c|c|c|c|c|c|c|}
\hline 1894 (P.) & 2.81 & 5. 09 & 3.04 & 3.98 & 3.90 & 3.63 & 2.41 & 3.57 & 2.64 & 1.20 & 0.63 & 5.18 & 38.08 \\
\hline 1895 (P.).. & 4.54 & .64 & 2.10 & 3.10 & 2.88 & 4. 94 & 5.68 & 1.35 & .41 & .90 & 7.01 & 5.31 & 38.86 \\
\hline 1901 (P.) & .98 & 1.16 & 3. 59 & 2.49 & 2.45 & 4.12 & 2.85 & 2.86 & 2.78 & .49 & 1.17 & 4.59 & 29.53 \\
\hline 190$\}^{(P .)}$ & 2.43 & 6.05 & 3.18 & 4.82 & 2.33 & 3.52 & 1.25 & 3.51 & .83 & 1.60 & 2. 71 & 1.58 & 33.69 \\
\hline $1805\{(\mathrm{~V}.) \ldots \ldots$ & -1.6 & +1.7 & -.8 & +.4 & $|-1.5|$ & -.8 & -2.5 & .0 & -2.00 & -1.2 & -1.4 & -2.3 & -12.07 \\
\hline $1004\{($ P. $) \ldots \ldots$. & 2. 43 & 3.54 & 6.49 & 2.67 & 1.77 & 1.71 & 1.70 & 2.11 & 2.65 & .87 & .25 & 3.66 & 29.25 \\
\hline${ }^{10}\{(\mathrm{~V})$. & -1.6 & -1.0 & +2.5 & -1.8 & -2.0 & -2.6 & -2.1 & -1.4 & -.17 & -2.54 & -3.81 & -.2 & -16.8 \\
\hline
\end{tabular}

From this table it appears that the smallest monthly precipitation in the first period was 0.4 inch and in the second period $0.25 \mathrm{inch}-$ that is, there was one-fourth inch or more rainfall per month at each of these places during both these dry periods. There is seen to be an anmual deficiency at Cincinnati of 20.52 inches in 1901, a deficiency of 10.2 inches in 1904, and an accumulated deficiency from 1901 to 1904 of 39.7 inches. The deficiency at Louisville was 12.1 inches in 1903 and 16.8 inches in 1904.

\section{RUN-OFF AND DISCHARGE.}

As a result of the large deficiency in the precipitation over this drainage basin, especially south of the Ohio, the flow of the streams became very small, causing great inconvenience and loss to navigation and other interests along the river. The following table gives the fluctuations of the surface of Ohio River at Wheeling, Portsmouth, and Louisville from August to December, 1895 to 190t, as shown by the United States Weather Burean gages at these places. The greatest, the least, and mean gage height for each month is given at each of these places.

IRR $147-05 \mathrm{M}-12$ 
Gage height, in feet, in places along the Ohio, August to December, 1895 to 1904.

\begin{tabular}{|c|c|c|c|c|c|c|c|c|c|c|}
\hline \multirow{2}{*}{ Place. } & \multirow{2}{*}{ Year. } & \multicolumn{3}{|c|}{ August. } & \multicolumn{3}{|c|}{ September. } & \multicolumn{3}{|c|}{ October. } \\
\hline & & From- & To- & Mea & From- & To- & Mean. & From- & To- & Mean. \\
\hline \multirow{2}{*}{$\begin{array}{l}\text { Wheeling, W. } \\
\text { Va. }\end{array}$} & 1895 & 3.5 & 1. 2 & 2. & 3.3 & 1.7 & 2.3 & 1.9 & 0.6 & 1.2 \\
\hline & (1904 & 5.1 & 1.6 & 3. & 3.4 & 1.3 & 2.2 & 4.9 & .2 .6 & 3.2 \\
\hline \multirow{2}{*}{$\begin{array}{l}\text { Ports mouth, } \\
\text { Ohio. }\end{array}$} & $\int 1895$ & 6.0 & 3.6 & 4. & 4.1 & 2.5 & 3.8 & 2.9 & 1.3 & 1.7 \\
\hline & 〈1904 & 6.3 & 3.6 & 4. & 5.3 & 2.1 & 3.3 & 3.6 & 1.9 & 2.8 \\
\hline \multirow{2}{*}{ Louisville, $\mathrm{Ky}$ - } & $\int^{1895}$ & 6.4 & 3.2 & 4. & 4.2 & 3.0 & 3.5 & 3.4 & 1.8 & 2.5 \\
\hline & ไ1904 & 4.0 & 3.5 & 3. & 4.0 & 2.5 & 3.1 & 2.8 & 2.0 & 2.5 \\
\hline \multirow{2}{*}{\multicolumn{2}{|c|}{ Place. }} & \multirow{2}{*}{ Year. } & \multicolumn{4}{|c|}{ November. } & \multicolumn{4}{|c|}{ December. } \\
\hline & & & From- & & $\because 0-$ & Mean. & From & & o- & Mean. \\
\hline \multirow{2}{*}{\multicolumn{2}{|c|}{ Wheeling, W. Va }} & $\left\{\begin{array}{l}1895 \\
0\end{array}\right.$ & 8. & & 0.8 & 2.9 & 16. & & 2.9 & 6.3 \\
\hline & & 1904 & 3. & & 1.3 & 2.2 & $" 16$. & & 1.4 & 3.8 \\
\hline \multirow{2}{*}{\multicolumn{2}{|c|}{ Portsmouth, Ohio }} & 1895 & 4. & 0 & 1.3 & 2.3 & 22. & & 3.1 & 8.8 \\
\hline & & 1904 & 4. & 3 & 2.4 & 2.9 & $71 \%$. & & 2.2 & 3.8 \\
\hline \multirow{2}{*}{ Louisville, $\mathrm{Ky}$} & & $\{1895$ & 4. & 1 & 1.8 & 2.3 & & .0 & 3.0 & 5.0 \\
\hline & & 1904 & 3. & 1 & 2.2 & 2.6 & & .4 & 2.2 & 2.6 \\
\hline
\end{tabular}

a Began to rise December 25 from 2.5 feet.

${ }^{b}$ Began to rise December 97 from 2.7 feet.

At Wheeling the range of stage in 1895 was from 0.6 to 3.5 , except for a few days in December; in 1904 it was from 1.3 to 5.1, except for a few days in December. It is thus seen that while the mean stage for the five months was less in 1904 than in 1895 , the stream at this place reached a lower stage in 1895 than in 1904.

The mean stage at Portsmouth for the five months is also less in 1904 than in 1895, but the lowest for any month was in 1895. The same is true of the stages at Louisville.

A stage of 0.6 foot at Wheeling means a depth on bars from Davis Island dam to Wheeling of from 6 to 20 inches. Hence from the latter part of July to near the end of December, 1895, and also for the same period of 1904 , boats could not pass from Pittsburg to Wheeling.

The United States Geological Survey has upward of 30 gaging stations in this drainage basin, and the intensity of the drought can be seen from the records at these stations. The location of these gaging stations on the more important streams is shown in $\mathrm{Pl}$. XVII (p. 174). In order to economize space, the principal results are presented in two tables.

The table on page 179 gives the run-off per square mile in cubic feet per second at $\Sigma 0$ of these stations for each month from June to December; also the mean for the seven months. The area of each 
of these basins above the point of measurement is given in the table on page 181, and the volume passing each station per month can easily be computed. South of Ohio River the minimum flow occurred in October; north of the Ohio it occurred at some time between September and November. The smallest monthly flow of any of these streams was that of Scioto River at Columbus, being 0.029 secondfoot per square mile in September.

Run-off per square mile. in second-feet, of streams in ohio drainage basin, June to December, 1904 .

\begin{tabular}{|c|c|c|c|c|c|c|c|c|}
\hline Stream and place. & June. & July. & Aug. & Sept. & Oct. & Nov. & Dec. & Mean. \\
\hline $\begin{array}{c}\text { Licking River, Pleasant } \\
\text { Valley, Ohio }-\end{array}$ & 0.221 & 1.310 & 0.197 & 0.130 & 0.154 & 0.145 & 0.398 & $0.43 \pi$ \\
\hline $\begin{array}{l}\text { Wabash, River, Logans- } \\
\text { port, Ind } \ldots . . . . . .\end{array}$ & 1.940 & .845 & .128 & .139 & .124 & .110 & .345 & .519 \\
\hline $\begin{array}{l}\text { Tippecanoe River, Delphi, } \\
\text { Ind }\end{array}$ & .634 & .660 & .282 & .318 & .310 & .236 & & .406 \\
\hline $\begin{array}{r}\text { Olentangy } \\
\text { bus, Ohio }\end{array}$ & .360 & 1.220 & .041 & .053 & .045 & .038 & .198 & .294 \\
\hline $\begin{array}{l}\text { Scioto River, Columbus, } \\
\text { Ohio }\end{array}$ & .231 & 1.380 & .048 & .029 & .042 & .046 & .105 & .269 \\
\hline $\begin{array}{l}\text { Mahoning River, Youngs- } \\
\text { town, Ohio }\end{array}$ & 1.76 & .324 & .246 & .073 & .049 & .084 & .238 & .396 \\
\hline $\begin{array}{l}\text { White (East Branch) River, } \\
\text { Shoals, Ind. }\end{array}$ & .485 & .314 & .132 & $.10 \%$ & .089 & .073 & .190 & .199 \\
\hline $\begin{array}{l}\text { Youghiogheny River, } \\
\text { Friendsville, Md }\end{array}$ & 1.19 & 0.627 & .183 & .153 & $.20 \%$ & .168 & 2. 72 & .747 \\
\hline New River: & & & & & & & & \\
\hline Radford, Va. & 1.49 & 1.03 & 1.08 & .520 & .299 & .492 & .576 & .784 \\
\hline Fayette, W. Va_........ & 1.34 & .828 & .604 & .274 & .173 & .239 & .427 & .555 \\
\hline $\begin{array}{l}\text { Greenbrier River, Alder- } \\
\text { son, W. Va. }\end{array}$ & .988 & .262 & .105 & .064 & .045 & .062 & $.30 \%$ & .262 \\
\hline $\begin{array}{l}\text { French Broad River, Old- } \\
\text { town, Tenn }\end{array}$ & 1.13 & .748 & 1.08 & .648 & .303 & .543 & .792 & .749 \\
\hline $\begin{array}{l}\text { Tennessee River, Knoxville, } \\
\text { Tenn }\end{array}$ & .725 & .678 & .703 & .362 & .219 & $.31 \%$ & .702 & .529 \\
\hline $\begin{array}{c}\text { Pigeon River. Newport, } \\
\text { Tenn }\end{array}$ & $.99 \%$ & .913 & .890 & .519 & .281 & .420 & .808 & .690 \\
\hline $\begin{array}{l}\text { Nolichucky River, Green- } \\
\text { ville, Tenn }\end{array}$ & 1.19 & $.84 \%$ & .921 & .521 & .336 & .535 & .791 & .734 \\
\hline $\begin{array}{l}\text { South Fork Holston River, } \\
\text { Bluff City, Tenn }\end{array}$ & .664 & .622 & .699 & .331 & .223 & .351 & .786 & .525 \\
\hline $\begin{array}{l}\text { Little Tennessee River, Jud- } \\
\text { son, N. C } \ldots . . . . . . .\end{array}$ & 1.47 & $1.0 \%$ & 1.60 & .951 & .444 & .699 & 1.43 & 1.095 \\
\hline $\begin{array}{l}\text { Tuckasegee River, Bryson, } \\
\text { N. C }\end{array}$ & 1.42 & 1.12 & 1.39 & .885 & .579 & .690 & 1.22 & 1.043 \\
\hline Hiwassee River: & & & & & & & & \\
\hline Murphy, N. C. & 1.30 & .927 & 1.40 & .688 & .429 & .546 & 1.07 & .909 \\
\hline Reliance, Tenn & .991 & .788 & 1.08 & .530 & .349 & .476 & 1.09 & .758 \\
\hline
\end{tabular}


The table below gives more detailed information of the flow at gaging stations in this basin for the five months July 20 to December 20 . Column 4 of this table gives the maximum daily rate of flow and column 5 the minimum daily rate during the five months at these stations. Column 6 gives the dates of beginning and ending of the period of six or more days when the discharge was least; column. 7 gives the number of days of this period, and column 8 the discharge during that time. It frequently happens that a dam on the strean holds back the water for a few days, so that the smallest daily flow may be much less than the average flow for a week or more when the flow is least. A comparison of the corresponding numbers in column.' 5 and 8 will give a good idea of the minimum flow, and also of the average for a week or longer when the flow was least.

Data on minimum flow of streams in Ohio drainage basin, 1904.

[Discharge in cubic feet per second.]

\begin{tabular}{|c|c|c|c|c|c|c|c|}
\hline \multirow[b]{2}{*}{ Name of river. } & \multirow[b]{2}{*}{ Place. } & \multirow{2}{*}{$\begin{array}{c}\text { Drain- } \\
\text { age } \\
\text { area } \\
\text { in } \\
\text { square } \\
\text { miles. }\end{array}$} & \multicolumn{2}{|c|}{$\begin{array}{l}\text { Daily dis- } \\
\text { charge, July } \\
20 \text { to Decem- } \\
\text { ber }: 0 \text {. }\end{array}$} & \multicolumn{3}{|c|}{$\begin{array}{l}\text { Period and amount of least dis- } \\
\text { charge. }\end{array}$} \\
\hline & & & $\begin{array}{l}\text { Maxi- } \\
\text { mum. }\end{array}$ & $\begin{array}{l}\text { Mini- } \\
\text { mum. }\end{array}$ & Date. & Days. & $\begin{array}{l}\text { Dis- } \\
\text { charge } \\
\text { for } \\
\text { period } \\
\text { in sec- } \\
\text { ond- } \\
\text { feet. }\end{array}$ \\
\hline Licking & $\begin{array}{l}\text { Pleasant Valley, } \\
\text { Ohio. }\end{array}$ & 696 & 810 & 66 & Nov.27-Dec.5. & 9 & 66 \\
\hline Olentangy & Columbus, Ohio & 520 & 104 & 5 & Sept. 26-Oet. 4 . & 9 & 5 \\
\hline Scioto & . do & 1,051 & 215 & i & Sept. 24-Sept.29 & 6 & 24 \\
\hline Mahoning . - & Youngstown, Ohio. & 958 & 985 & $a 0$ & Oct.1-Oct.10.. & 10 & $b 23$ \\
\hline Wabash ..... & Logansport, Ind. & 3,163 & 1,118 & 280 & Oct. 18-Nov.13. & 26 & 350 \\
\hline Tippecanoe . . . & Delphi, Ind ..... & 1,890 & 1,200 & 291 & Aug. 7-Aug. 16 & 10 & 335 \\
\hline White.. & Shoals, Ind. & 4,900 & 1,330 & 215 & Oct. $22-$-Dec. 23 & 63 & 360 \\
\hline Allegheny & Kittanning, Pa. & 8,690 & . & - & Sept. 19-Sept. 26 & 8 & 2,000 \\
\hline Kiskiminetas & Salina, Pa $\ldots$ & 1,769 & & & Sept.24-Oct. 6 . & 13 & 175 \\
\hline Blacklick $c^{\prime} \ldots$ & Blacklick, Pa & 403 & -- & $\ldots$ & Aug. 30-Sept. 8 . & 10 & 45 \\
\hline Youghiogheny & Confluence, Pa .... & 392 & & & Oct.1-Oct. 8.. & 8 & 35 \\
\hline Castleman ..... & ... do . . . . . & 482 & & $\cdots$ & Sept.22-Oct. 13 & 22 & 44 \\
\hline Laurel Hill c . & . . . do _ . . . . . & 126 & $-\ldots$ & .... & Oct. 14-Dec. 14 & 62 & 16 \\
\hline New & Radford, Va. & 2,725 & 14,905 & 690 & Oct. 13-Oct. 25 & 13 & 690 \\
\hline Do. - & Fayette, W. Va.- & 6,200 & 6,216 & 984 & Oct. 6-Oct.13.. & 8 & 1,050 \\
\hline Greenbrier ... & Alderson, W. Va & 1,344 & 217 & 46 & Sept. 30-Oct. 6 .. & 7 & 46 \\
\hline Cumberland . . & Nashville, Tenn ... & 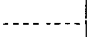 & 4,630 & 1,060 & Sept.24-Oct.2.. & 9 & 1,160 \\
\hline Tennessee ........ & Knoxville, Tenn... & 8,990 & 13,710 & 1,750 & Oct. 15-Nov. 3 ... & 20 & 1,930 \\
\hline Do......... & Chattanooga,Tein & $\ldots$ & -...... & $\ldots$ & Oct. 21-Nov.2 & 13 & 4,980 \\
\hline French Broad .... & Oldtown, Tenn .... & 1,737 & 2,955 & 400 & Oct. 4-Nov. 2 & 29 & 535 \\
\hline Pigeon . . .......... & Newport, Tenn & 655 & 1,660 & 160 & Oct.11-Nov.2 & 23 & 180 \\
\hline Nolichucky ....... & Greenville, Tenn & 1,099 & $\vartheta, 043$ & 320 & Oct.13-Oet.27 .- & 15 & 355 \\
\hline Little Tennessee.. & Judson, N. C........ & 675 & 3,280 & 275 & Oct.13-Nov.1 & 20 & 275 \\
\hline Tuckasege日_...... & Bryson, N. C & 662 & 3,050 & 340 & Oct. $28-\mathrm{Nov} .2$ & 6 & 340 \\
\hline $\begin{array}{l}\text { South Fork Hol- } \\
\text { ston. }\end{array}$ & Bluff City, Tenn... & 898 & 1,140 & 150 & Oct. 9-Nov. 3 & 26 & 190 \\
\hline Hiwassee .... & Murphy, N. C ....... & 410 & 3,230 & 150 & do $\ldots \ldots \ldots$ & 26 & 190 \\
\hline Do...... & Reliance, Tenn .... & 1,180 & 3,780 & 380 & Oct. 19-Oct. 26 . & 8 & $3 \% 0$ \\
\hline
\end{tabular}

a Affẹcted by dam.

${ }^{b}$ Average for ten days.

c Creek. 
It will be seen that the streams south of the Ohio not only have a larger minimum flow per square mile of drainage area, but their flow fluctuates lesis rapidly than those north of the river.

SOME EFFECTS OF THE DROUGHT.

The drought had a serious effect on the navigation interests of the Ohio. Boatmen declare that it was the worst in their recollection. For seren months navigation was practically suspended from Wheeling to Pittsburg. It is estimated that $13,000,000$ bushels of coal were tied up at points along the Ohio and tributaries waiting for a rise in the river to take them down to Cairo. The South was suffering for the coal that was held along the river and the miners were working on half time on account of lack of facilities for transporting the coal to the consumers. (See Pl. XVIII.)

The great steel and iron industries in western Pennsylvania and Ohio suffered directly from lack of suitable water for boilers and indirectly for lack of fuel, the railroads not being able to haul the fuel for lack of water for boiler purposes. The Edgar Thompson Company shut down part of its steel plant for lack of water. The furnaces had no coke and the boilers had badly corroded from the sulphur in the water which came from the mines. The National Tube Works and the Duquesne and Homestead mills could not run to their full capacity. Many of the coke ovens suspended operations and the loss in the coke region was estimated at $\$ 1,000,000$ per month.

The oil industries suffered for lack of water and in many cases this scarcity caused suspension for a time. Where it was possible in the oil fields water was hauled for the boilers from considerable distances.

The railroads suffered to a large extent. Many of the streams from which their local supplies were taken became dry and it was necessary to haul the water for the engines in some cases from a long distance. The writer counted 12 tank cars of water in a train on the Baltimore and Ohio that was on its way from Grafton to Clarksburg and other watering stations. The Pennsylvania Railroad and other roads in this basin were compelled to haul water for their engines to various points. The water was not only scarce but very poor in quality, containing so much sulphur as to render it almost unfit for boiler use.

Many farmers suffered inconvenience and loss from lack of water for stock and household purposes. Springs, wells, and streams of considerable size in West Virginia and Kentucky were dry and farmers were compelled to haul water from a considerable distance.

The water supply of several towns in western Pennsylvania, West Virginia, and Kentucky was almost exhausted and property was without adequate fire protection for a time. The water company which supplies Braddock, Pa., announced in December that it 
could not guarantee a supply of water. The Westmoreland Water Company, which supplies Greensburg, Jeannette, Manor, and Irwin, Pa., with water, stated on December 21 that there was only sufficient for a week's supply. Many towns found it necessary to curtail the use of water for bathing purposes.

The remedy for this lack of water during droughts is to store an abundant supply of flood water. Fortunately the mountainous region of West Virginia, Pennsylvania, and Kentucky affords many sites for the storage of moderately large volumes of water at a reasonable cost. Already many of these towns in this region have such storage supplies, and this drought will undoubtedly stimulate the construction of other storage reservoirs for the supply of citie: and towns and also industrial organizations.

\section{A METHOD OF COMPUTING CROSS-SECTION AREA OF WATER WAYS.}

By E. C. Murphy.

The proper size of channel cross section of a stream depends mainly on the rate of flow of the stream. The method proposed in this paper for finding cross-section area is based on the fundamental formula that $F=\frac{Q}{T}$, where $F$ is the cross-section area of the stream, $Q$ the maximum discharge in cubic feet per second, and $T^{r}$ is the velocity of the maximum discharge in the channel.

The formula in common use for this purpose generally have the form $F=C M^{k}$, in which $F$ is the cross-section area in square feet, $M$ is the drainage area in square miles or acres, $C$ is a quantity whose value depends on the character of the country, and $k$ is a fraction generally less than unity; e. g., the formula used by tine engineers of the Missouri Pacific Railway Company is $F=0.25 \mathrm{~N}$ to $0.17 \mathrm{M}$. The proposed method is based on measiurements of the flood flow of streams and on the observed maximum range of stage and slope of each particular stream.

\section{FACTORS DETERMINING MAXIMUM DISCHARGE.}

The maximum discharge of a stream depends on several quantities. Primarily it is dependent on-

(1) Extent, duration, and intensity of precipitation, especially the latter in the case of small drainage basins.

(2) Direction of motion of the storm causing the flood. If the stor'm moves in the direction of flow of the stream the intensity of flood will be greater than if it moves in the opposite direction or across it. 


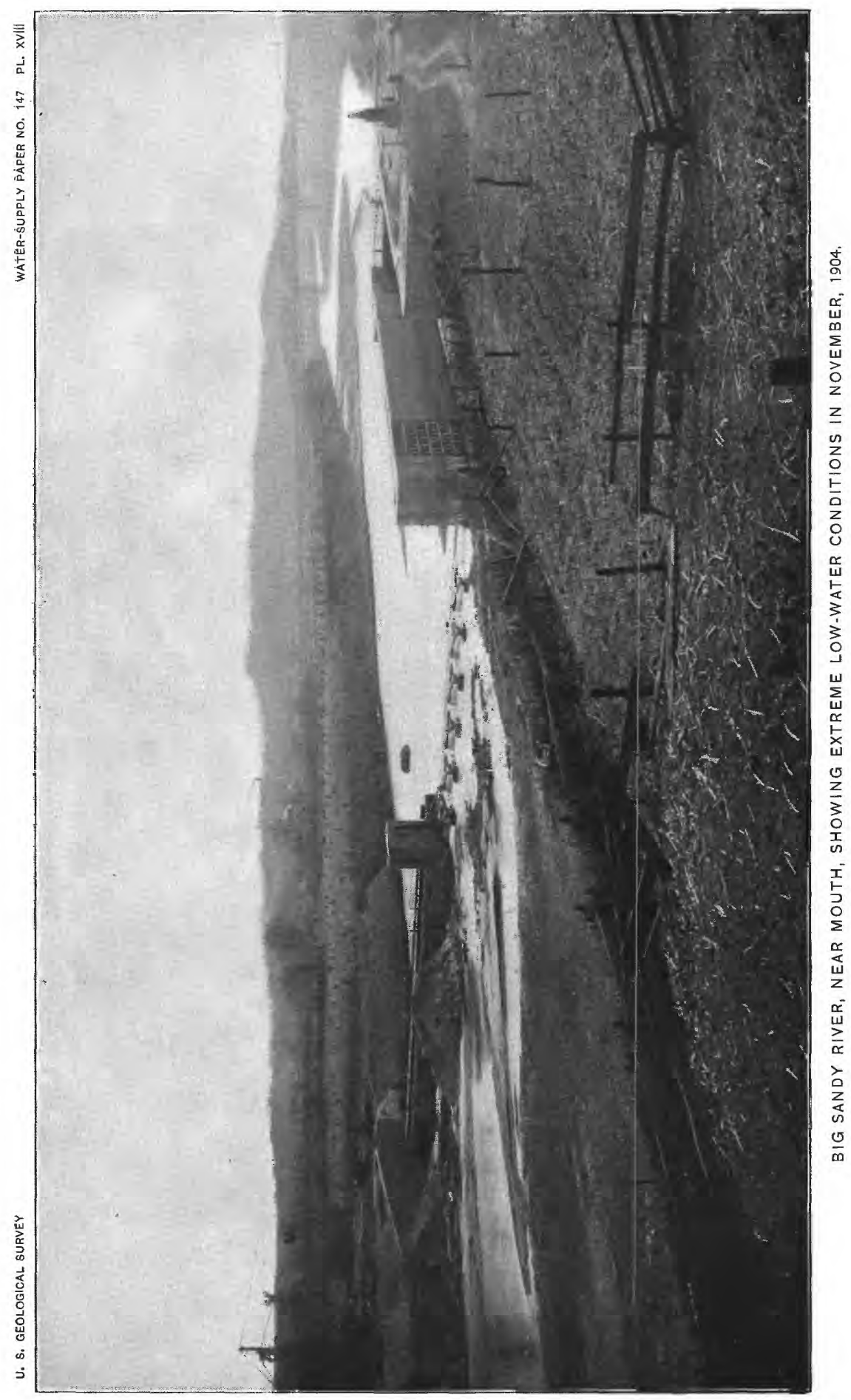


(3) The amount of snow on the ground and the temperature during the'storm. Large floods are often due largely to melting snow when the ground is frozen, and in such cases the run-off is much larger than the rainfall.

(4) The storage, both natural and artificial, in the drainage basin. Storage spreads the flood over a larger period and thus reduces the maximum rate of flow.

(5) The size of the drainage basin. Rain storms of great intensity generally cover a comparatively small area, and a larger part of a small drainage basin is more likely to be covered by a very intense storm than of a larger basin. The maximum discharge per square mile will, therefore, increase as the size of the drainage basin decreases.

(6) The physiography of the drainage basin. The maximum rate of flow from a comparatively long and narrow drainage basin, with tributaries entering a considerable distance apart, will be less than from a basin of nearly circular shape of the same size, but with the tributaries entering the main stream in close proximity. Steep, impervious, deforested slopes of drainage basin, steep slope of bed of tributaries, and small slope of main stream intensify flood flow.

Among the more or less artificial conditions that increase the flow may be mentioned controlled storage in the basin; deforestation and cultivation; reduction in width of channel by placing abutments of bridges in the stream; the use of piers that prevent scour of bed, collect drift, and hold back a part of the flow for a time, causing a greatly increased flood wave; the formation of ice gorges; and the failure of dams and reservoir walls.

Freshets occur on all streams, usually once a year, sometimes two or more times a year; great floods that result from natural causes occur at irregular intervals, varying from a few years to many years apart. It is impossible to predict the time of their occurrence or determine whether the largest recorded flood is the largest that will ever occur.

It is very difficult to measure the discharge of a stream at maximum stage with accuracy. At such a time the stream usually carries much drift, overflows its banks, and changes its stage rapidly, all of which make accurate measurement of flow difficult.

\section{MAXIMUM RATE OF DISCHARGE.}

It may be seen, from the foregoing and other facts that might be cited, that the rate of flood discharge of streams in different drainage basins will differ by a considerable amount. The difficulty of measuring the rate of flow of any flood and the uncertainty whether any flood will be the greatest that will ever occur on that stream are both 
so great that it is useless to attempt to figure closely the maximum rate of flow. It will suffice, therefore, to divide the country into six or eight parts, according to the topography and rainfall, and to obtain a relation between rate of flow and size of drainage basin for each. The tables below give the maximum rate of flow per square mile from drainage basins in various parts of the United States, the drainage area in square miles above the point of measurement, and the date of flood. It is impossible to give, except in a very few cases, the duration of the maximum rate of flow. In some cases the duration was probably not more than half an hour; in other cases the maximum rate given is the mean for several hours, and possibly for twenty-four hours of the day when the flow was greatest. It is assumed that the maximum rate given is for a period of less than twenty-four hours, unless otherwise stated.

These data are selected from a large mass of flood-flow records and are the largest rates of flow that appear to be fairly reliable that the author has seen. Some of these were obtained from careful weir measurements, while others are rough estimates.

Maximum rate of discharge of streams in northeastern United states. [In second-ieet per square mile.]

\begin{tabular}{l} 
Stream and place. \\
\hline Budlong Creek, Utica, N. Y ... \\
Sylvan Glen Creek, New Hart- \\
ford, N.Y. \\
Pequest River, Hunts Pond, \\
N.J. \\
Starch Factory Creek, New \\
Hartford, N. Y. \\
Reels Creek, Deerfield, N. Y... \\
Skinner Creek, Mannsville, \\
N.Y. \\
Coldspring Brook, Mass ...... \\
Croton River, South Branch, \\
N.Y. \\
Woodhull . Reservoir, Herki- \\
mer, N. Y. \\
Stony Brook, Boston, Mass .... \\
Great River, Westfield, Mass.. \\
Smartswood Lake, N. J....... \\
Williamstown Ri v e r, W il- \\
liamstown, Mass. \\
Croton River, West Branch, \\
N. Y. \\
Beaverdam Creek, Altmar, \\
N.Y. \\
Trout Brook, Centerville, N.Y. \\
Wantuppa Lake, Fall River, \\
Mass. \\
Pequest River, Huntsville, \\
N. J. \\
Sawkill, near mouth, N.J ..... \\
\end{tabular}

\begin{tabular}{|c|c|c|c|}
\hline $\begin{array}{c}\text { Drain- } \\
\text { age area, } \\
\text { in square } \\
\text { miles. }\end{array}$ & Date. & $\begin{array}{l}\text { Maxi- } \\
\text { mum } \\
\text { rate. }\end{array}$ & Authority. \\
\hline 1.13 & Mar. 25,1904 & 120.40 & U.S. Geol. Sur. W. S. P. No. $14 \pi$. \\
\hline 1.18 & .... do _....... & 56.58 & Do. \\
\hline 1. 60 & & 25.30 & N.J.Geol. Sur., 1894, pt. 4. \\
\hline 3.40 & Mar. 25, 1904 & 109.62 & U.S. Geol. Sur. W.S. P. No. 147. \\
\hline 4.40 & Mar. 26, 1904 & 48.36 & Do. \\
\hline 6.40 &,-- 1891 & 124.20 & U. S. B. Engrs. D. W., 1899. \\
\hline 6.43 & Feb.,- 1886 & 48.40 & Trans. Am. Soc. C. E., vol. 25. \\
\hline 7.80 & $-\quad-, 1869$ & 73.90 & Trans. Am. Soc. C. E., vol.4. \\
\hline 9.40 &,-- 1869 & 77.80 & Do. \\
\hline 12.7 & & 121.00 & $\begin{array}{l}\text { Report of Stony Brook Flood } \\
\text { Com. }\end{array}$ \\
\hline 14.8 & & a71. 40 & Report of H. F. Mills. \\
\hline 16.0 & $\ldots$ & 68.00 & N. J. Geol. Sur., 1894, pt. 4. \\
\hline 16.5 & & 34.00 & U. S. B. Engrs. D. W., 1899. \\
\hline 20.5 & Jan.,- 1874 & 54.40 & E. M. Treman. \\
\hline 20.7 & & 111.00 & U. S. B. Engrs. D. W , 1899. \\
\hline 23.0 & & 50.60 & Do. \\
\hline 28.5 &,-- 1875 & 72.00 & Trans. Am. Soc. C. E., vol.4. \\
\hline 31.4 & & 19.30 & N. J. Geol. Sur., 1894, pt. $3 .$. \\
\hline 35.0 & & 228.60 & U.S.Geol.Sur. W.S.P. No. 35. \\
\hline
\end{tabular}

average flow for day of maximum discharge. 
Maximum rate of discharge of streams in northeastern United states-Cont'd.

\begin{tabular}{l} 
Stream and place. \\
\hline Whippany River, Whippany, \\
N.J. \\
Cuyadutta Creek.Johnstown, \\
N. Y. \\
West Canada Creek, Motts \\
Dam, N. Y. \\
Sauquoit Creek, New York \\
Mills, N. Y.
\end{tabular}

Rockaway River, Dover, N.J. Oneida Creek, Kenwood, N. Y Flat River, R. I.

Camden Creek, Camden, N. Y Nine Mile Creek, Stittville, N.Y.

Wissahickon Creek, Philadelphia, Pa.

Sandy Creek, Allendale, N. Y Rock Creek, Washington, D. C Sudbury River, Farmington, Mass.

Pequanock River, Pompton, N. J.

Hockanum River, Conn ........

Nashua River, Mass

Independence Creek, Crandall, N. Y.

Passaic River, Chatham, N.J. Deer River, Deer River, N. Y. Wanaque River, N. J . ......... Tohickon Creek, Mount Pleasant, $\mathbf{P a}$.

Fish Creek, East Branch, Point Rocks, N. Y.

Nashna River, Mass

Sandy Creek, North Branch, Adams, N. Y.

Scantic River, North Branch, Conn.

Ramapo River, Mahwah, N. J Rockaway River, Boonton, N. J.

Patuxent River, Laurel, Md.

Neshaminy Creek, below forks, $\mathrm{Pa}$.

Oriskany Creek, Colemans, N. Y.

Oriskany Creek, Oriskany, N. Y.

Perkiomen Creek, Frederick, $\mathrm{Pa}$.

Mohawk River, Ridge Mills, N. Y.

Mohawk River, State dam, Rome, N. Y.

Ramapo River, Pompton, N.J Fish Creek. West Branch, McConnellsville, N. Y.

Salmon River, Altmar, N. Y . Black River, Forestport, N. Y Croton River, Croton dam,
N.Y.

\begin{tabular}{|c|c|c|c|}
\hline $\begin{array}{c}\text { Drain- } \\
\text { age area, } \\
\text { in square } \\
\text { miles. }\end{array}$ & Date. & $\begin{array}{l}\text { Maxi- } \\
\text { mum } \\
\text { rate. }\end{array}$ & Authority. \\
\hline 37.0 & Oct.,- 1903 & 61.62 & U. S. Geol. Sur. ( unpublished). \\
\hline 40.0 & $-\quad-, 1896$ & 72.40 & U. S. B. Engrs. D. W., 1899. \\
\hline 47.5 & & 34.10 & Do. \\
\hline 51.5 & & 53. 40 & Do. \\
\hline 52.5 & - & 43.00 & N. J. Geol. Sur., 1894. \\
\hline 59.0 & $-\quad-, 1890$ & 41.20 & U. S. B. Engrs. D. W., 1899 \\
\hline 61.0 & Mar. -, 1843 & 120.00 & Trans. Am. Soc. C. E., vol. 4. \\
\hline 61.4 & June--, 1889 & 24.10 & U. S. B. Engrs. D. W., 1899. \\
\hline 62.6 & Aug. --, 1898 & 124.90 & Do. \\
\hline 61.6 &,$-- 189 k$ & 43.50 & U. S. Geol. Sur., 20 An.. pt. 4. \\
\hline 68.4 &,-- 1891 & $8 \pi .70$ & U. S. B. Engrs. D. W., 1899. \\
\hline 77.5 & (. & 126.30 & Tech. Quar. Mass. Inst.. 1891. \\
\hline 78.0 &,$-- 189 \pi$ & 41.36 & $\begin{array}{l}\text { Ch. engr. water dept., N. Y. } \\
\text { City. }\end{array}$ \\
\hline 78.0 & Mar. - 1902 & 55.78 & U. S. Geol. Sur. ( unpublished). \\
\hline 79.0 & $\ldots$. & 78.10 & Ch. U.S. Engr. Corps, 1878. \\
\hline 84.5 & $-\quad-, 1850$ & 71.04 & Trans. Am. Soc. C.E., vol. 4. \\
\hline 93.2 & Apr:,- 1869 & 66.50) & $\begin{array}{l}\text { Black River Water Claims, } \\
\text { vol. 1. (unpublished). }\end{array}$ \\
\hline 100 & Oct. 11,1903 & 17.20 & U.S. Geol. Sur. (unpublished). \\
\hline 101 & Apr:,- 1869 & 78.10 & U.S. B. Engrs. D. W., 1899. \\
\hline 101 & Sept.,- 1882 & 66.00 & N. J.Geol. Sur., 1894. \\
\hline 102 &,-- 1885 & $11: 3.50$ & Rept. Phila. water board. \\
\hline 104 & --1897 & 80.50 & U. S. B. Engrs. D. W., 1899. \\
\hline 109 & $-\quad-, 1848$ & 104.53 & Trans. Am. Soc. C. E., vol.4. \\
\hline 110 & $-\quad-, 1897$ & 67.30 & U.S. B. Engrs. D. W., 1899. \\
\hline 118 & & 51.80 & Ch. U.S. Engr. Corps, 1878. \\
\hline 118 & Oct.,- 1903 & 105.09 & U. S.Geol. Sur. (unpublished). \\
\hline .25 & Mar. 2,190: & 22.24 & Do. \\
\hline 137 &,- 1897 & 31.20 & U.S. Geol.Sur., 19 An.,pt. 4. \\
\hline 139 & $-\quad-, 1894$ & 97.60 & Eng. News, May, 1893. \\
\hline 141 & $-\quad-1888$ & 55.80 & U. S. B. Engrs. D. W., 1899. \\
\hline 144 & Mar. 25, 1904 & 29.00 & U. S. Geol. Sur. W. S.P. No.147. \\
\hline 152 & $-\quad-, 1889$ & 69.20 & Rept. Phila. water board. \\
\hline 153 & & 46. 40 & U.S. B. Engrs. D. W., 1899. \\
\hline 158 & Mar. 26, 1904 & 27.34 & U.S.Geol. Sur. W. S.P. No.147. \\
\hline 160 & $-\quad-, 1882$ & 56.10 & N.J. Geol. Sur., 1894. \\
\hline $18 \%$ & $-\quad-, 1885$ & 32.70 & U.S. B. Engrs. D. W., 1899. \\
\hline 221 & & 27.60 & Do. \\
\hline 268 & & 39.00 & Do. \\
\hline 339 & & 74.90 & Trans. Am. Soc. C. E., vol. 4 . \\
\hline
\end{tabular}


Maximum rate of discharge of streams in northeastern Thited states-Cont'd.

\begin{tabular}{|c|c|c|c|c|}
\hline Stream and plare. & $\left|\begin{array}{c}\text { Drain- } \\
\text { age area, } \\
\text { in square } \\
\text { miles. }\end{array}\right|$ & Date. & $\begin{array}{l}\text { Maxi- } \\
\text { mum } \\
\text { rate. }\end{array}$ & Authority. \\
\hline Great River, Westfield, Mass. - & 350) & -- & a 151.40 & H. F. Mills. \\
\hline $\begin{array}{l}\text { East Canada Creek, Dolgeville, } \\
\text { N. Y. }\end{array}$ & 356 & Aug. --, 1898 & 24.70 & U.S. B. Eng1s. D. W., 1899. \\
\hline Moose River, Ayers mill, N. Y .- & 407 & & $31.1(x)$ & $\begin{array}{l}\text { Black River Water Claims } \\
\text { Com., vol. } 1 .\end{array}$ \\
\hline Stony Creek, Johnstown, Pa... & $4: 8$ & 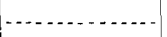 & 70.00 & J.J.R. Groes. \\
\hline $\begin{array}{l}\text { West Canada Creek, Middle- } \\
\text { ville, N. Y. }\end{array}$ & $51 \%$ & Ang. --, 1898 & 24.90 & U.S. B. Engrs. D. W., 1899. \\
\hline Farmington River, Conn ...... & $5 \times 4$ & 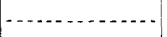 & 41. 50 & Ch. U. S. Engr. Corps, 1878. \\
\hline $\begin{array}{l}\text { Monocacy River, Frederick, } \\
\text { Md. }\end{array}$ & 665 &,- 1898 & $29.81)$ & U. S. Geol. Snr., 20 An. \\
\hline Passaic River, Little Falls, N.J & $7 \% 3$ & Sept.,-- 1882 & 24.20 & N. J. Geol. Sur. 1894, pt. 3. \\
\hline $\begin{array}{l}\text { North River, Port Republic, } \\
\text { Va. }\end{array}$ & 804 & $\ldots-, 1496$ & 29.80 & U. S. Geol. Sur., 20 An. \\
\hline Passaic River, Dundee, N. J. & 8283 & Oct. 10,1903 & 43.38 & U. S. Geol. Sur. W. S. P. No. 92. \\
\hline North River, Glasgow, Va .... & 831 &,-- 1896 & 44.80 & U. S. Geol. Sur., 20 An. \\
\hline $\begin{array}{l}\text { Raritan River, Boundbrook, } \\
\text { N.J. }\end{array}$ & 879 &,$-- 18 \times 2$ & 59.30 & N. J. Geol Sur., 1894, pt. 3. \\
\hline $\begin{array}{l}\text { Potomac, North Branch, Cum- } \\
\text { berland, Md. }\end{array}$ & 891 & $-\quad-, 1897$ & 22.80 & U. S. Geol. Sur., 19 An. \\
\hline Black River; Lyons Falls, N. Y. & 997 & Apr. -.1869 & 46.00 & U. S. B. Engrs. D. W., 1899. \\
\hline $\begin{array}{l}\text { Schoharie Creek, Fort Hunter, } \\
\text { N. Y. }\end{array}$ & 948 & $-\quad-, 1892$ & 44.00 & Do. \\
\hline $\begin{array}{l}\text { Genesee River, Mount Morris, } \\
\text { N. Y. }\end{array}$ & $1,0 \% 0$ & $1 \times 94-1896$ & $39 .: 20$ & U. S. Geol. Sur., 20 An. \\
\hline $\begin{array}{l}\text { Mohawk River, Little Falls, } \\
\text { N. Y. }\end{array}$ & 1,306 & Mar. 2, 1902 & 21.83 & U. S. Geol. Sur. W.S. P. No \\
\hline $\begin{array}{l}\text { Greenbrier River, Alderson, } \\
\text { W. Va. }\end{array}$ & 1,344 &,$- 189 \pi$ & 41.60 & U. S. Geol. Sur., 19 An. \\
\hline Black River, Carthage, N. $\mathbf{Y}^{\top}$. & 1,812 & Apr. - 1869 & 21.30 & U. S. B. Engr's. D. W., $1 \times 99$. \\
\hline $\begin{array}{l}\text { Schuylkill Riт̣er, Fairmount. } \\
\text { Pa. }\end{array}$ & 1,915 &,- 1898 & 19.20 & U. S. Geol. Sur., 20 An. \\
\hline Chemung River, Elmira, N. Y. & 2,055 & June $-.18 \times 9$ & 6iv. 10 & $\begin{array}{l}\text { Rept. of F. Collingswood to } \\
\text { city, } 1889 \text {. }\end{array}$ \\
\hline James River, Buchanan, Va... & $2,115 \mathrm{~S}$ & $--.1 \times 96$ & 15.60 & U. S. Geol. Sur., 19 An. \\
\hline $\begin{array}{l}\text { Androscoggin River, Rum- } \\
\text { ford, Me. }\end{array}$ & $2.22)$ &,-- 1869 & 25.110 & U. S. Geol. Sur., 90 An. \\
\hline Genesee River, Rochester, N.Y. & $2,3 t^{2} 5$ & Mar. -, 1865 & 00 & U. S. B. Engrs. D. W, 1899. \\
\hline $\begin{array}{l}\text { Hudson River, Fort Edward, } \\
\text { N. Y. }\end{array}$ & 2.825 & Apr.,- 1900 & 15.60 & $\begin{array}{l}\text { Rept. E. A. Bond, State engr., } \\
1900 .\end{array}$ \\
\hline $\begin{array}{l}\text { Shenandoah River, Millville, } \\
\text { W. Va. }\end{array}$ & 2,995 &,- 1898 & 11.40 & U. S. Geol. Sur., 19 An. \\
\hline Mohawk River, Rexford, N. Y. & 3,384 & $-\quad-, 1892$ & 23.10 & U. S. B. Engrs. D. W., 1899. \\
\hline Merrimac River, Lowell, Mass. & $4,0<5$ & $-\cdots,-$ & 19.80 & N. J. Geol. Sur., 1894, pt. 3. \\
\hline $\begin{array}{l}\text { Kennebec River, Waterville, } \\
\text { Me. }\end{array}$ & $4,411)$ & $-\quad-, 1896$ & 25.20 & U. S. Geol. Sur., 19 An. \\
\hline $\begin{array}{l}\text { Susquehanna, West Branch, } \\
\text { Williamsport, } \mathrm{Pa} .\end{array}$ & $4,51 \times$ & & 11.60 & Eng. News, Feb. 14, 1891. \\
\hline $\begin{array}{l}\text { Hudson River, Mechanicsville, } \\
\text { N. Y. }\end{array}$ & $4,5(k)$ & $-\quad-.1869$ & 15. 50 & U. S. Geol. Saur., 19 An. \\
\hline $\begin{array}{l}\text { Merrimac River, Lawrence, } \\
\text { Mass. }\end{array}$ & 4,553 & & 23.40 & Do. \\
\hline Potomac River, Dam No. 5, Md. & 4,640 & & 22.20 & N. J. Geol. Sur., 1894, pt. 4. \\
\hline $\begin{array}{l}\text { Delawar'e River, Lambertville, } \\
\text { N. J. }\end{array}$ & 6,500 & & 53.80 & Trans. Am. Soc. C. E., vol. 10. \\
\hline Delaware River, N.J .......... & 6,750 & & 50.00 & Do. \\
\hline DelawareRiver.Stockton, N.J & 6,790 & $\cdots \quad-, 1841$ & 37.50 & N. J. Geol. Sur., 1894, pt. 3. \\
\hline $\begin{array}{l}\text { hanna River, Northum- } \\
\text { nd, Pa. }\end{array}$ & $6,8(n)$ & $-\quad-1889$ & 17.50 & Eng. News, Feb. 14, 1891. \\
\hline
\end{tabular}


Maximum rate of discharge of streams in northeastern United States-Cont'd.

\begin{tabular}{|c|c|c|c|c|}
\hline Stream and place. & $\begin{array}{c}\text { Drain- } \\
\text { age area, } \\
\text { in square } \\
\text { miles. }\end{array}$ & Date. & $\begin{array}{l}\text { Maxi- } \\
\text { mum } \\
\text { rate. }\end{array}$ & Authority. \\
\hline $\begin{array}{l}\text { Connecticut River, Holyoke, } \\
\text { Mass. }\end{array}$ & 8,660 & May -, 1854 & 21.10 & Ch. U.S. Engr. Corps, $18 \% 8$. \\
\hline $\begin{array}{l}\text { Potomac River, Point of Rocks, } \\
\text { Md. }\end{array}$ & 9,654 & $-\quad-, 1897$ & 19.40 & U.S. Geol.Sur., 19 An. \\
\hline $\begin{array}{l}\text { Connecticut River. Hartford, } \\
\text { Conn. }\end{array}$ & 10,234 & & 20.30 & Trans. Am. Soc. C. E., vol.7. \\
\hline Potomac River, Md . . . . . . & 11,043 & & 42.60 & Eng. News, May $25,1893$. \\
\hline $\begin{array}{l}\text { Potomac River, Great Falls, } \\
\text { Md. }\end{array}$ & 11,487 &,- 1889 & 41.20 & U.S. Geol. Sur.,14 An. \\
\hline $\begin{array}{l}\text { Potomac River, Chain Bridge, } \\
\text { D. C. }\end{array}$ & 11,545 & $-\quad-, 1893$ & 17.20 & Do. \\
\hline $\begin{array}{l}\text { Susquehanna River, Harris. } \\
\text { burg, Pa. }\end{array}$ & 24,030 & $-\ldots-1894$ & 18.90 & U.S.Geol.Sur., 18 An. \\
\hline
\end{tabular}

IIaximum rate of discharge of streams in southeastern United States.

[In second-feet per square mile.]

\begin{tabular}{|c|c|c|c|c|}
\hline Stream and place. & $\mid \begin{array}{c}\text { Drain- } \\
\text { age area, } \\
\text { in square } \\
\text { miles. }\end{array}$ & Date. & $\begin{array}{l}\text { Maxi- } \\
\text { mum } \\
\text { rate. }\end{array}$ & Authority. \\
\hline $\begin{array}{l}\text { Coosawattee River, Carters, } \\
\text { Ga. }\end{array}$ & 532 & May 21, 1901 & 31.86 & U.S. Geol.Sur. W.S. P. No. \\
\hline Etowah River, Canton, Ga... & 604 & Jan. -, 1895 & 31.50 & U.S.Geol. Sur., 18 An. \\
\hline $\begin{array}{l}\text { Tuckasegee River, Bryson. } \\
\text { N. C. }\end{array}$ & 662 & Mar. 19,1899 & 58.23 & U.S.Geol.Sur., 21 An. \\
\hline $\begin{array}{l}\text { Little Tennessee River, Jud- } \\
\text { son, N.C. }\end{array}$ & 675 & Dec. 29,1901 & 85.24 & U.S. Geol. Sur. W.S. P. No. 75. \\
\hline Broad River, Carlton, Ga..... & 762 & Feb. 2,1902 & 38.22 & U. S. Geol. Sur. W. S. P. No. 83 . \\
\hline Saluda River, Waterloo, S.C . & 1,056 & June 8,1903 & 18.00 & U.S.Geol. Sur. W.S.P. No. 94. \\
\hline Catawba River, Catawba, N. C. & 1,535 & May 29, 1901 & 53.10 & U.S.Geol. Sur. W. S.P. No. 75. \\
\hline $\begin{array}{l}\text { Chattahoochee River, Oak- } \\
\text { dale, Ga. }\end{array}$ & 1,560 & Feb. $2 \pi, 1899$ & 27.92 & U.S. Geol. Sur., 21 An. \\
\hline Ocmulgee River, Macon, Ga... & 2,425 & Ma1. 1,1902 & 20.97 & U. S. Geol. Sur. W.S. P. No. 83. \\
\hline Yadkın Rıver, Salisbury, N.C. & 3,399 & Mar. -, 1899 & 31.60 & U.S.Geol. Sur., 21 An. \\
\hline $\begin{array}{l}\text { Tallapoosa River, Milstead, } \\
\text { Ala. }\end{array}$ & 3,840 & Dec. 30,1901 & 18.23 & U.S.Geol. Sur. W.S.P. No. 75. \\
\hline Coosa River, Rome, Ga & 4,001 & Dec. 31, 1901 & 16.04 & Do. \\
\hline Broad River, Alston, S. C..... & 4,609 & May $: 3,1901$ & .28 .44 & Do. \\
\hline $\begin{array}{l}\text { Black Warrior River, Tusca: } \\
\text { loosa, Ala. }\end{array}$ & 4,900 & Apr. 18,1900 & 27.89 & U.S. Geol. Sur., 22 An. \\
\hline New Rrver, Fayette, W. Va.... & 6,200 & Mar. 4,1899 & 17.83 & Do. \\
\hline Coosa River, Riverside, Ala ... & 6.850 & Oet. 8,1898 & 10.53 & U. S. Geol. Sur., 20 An. \\
\hline Savannah River, Augusta, Ga & 7,294 & Sept. -, 1888 & $a 42.50$ & U.S. Geol.Sur., 14 An. \\
\hline $\begin{array}{l}\text { Tennessee River, Chattanooga, } \\
\text { Tenn. }\end{array}$ & 21,418 & Apr.,- 1896 & 20.80 & U.S. Geol. Sur., 19 An. \\
\hline
\end{tabular}


Maximum rate of discharge of streams in central Trited stutes.

[In second-feet per square mile.]

\begin{tabular}{|c|c|c|c|c|}
\hline Stream and place. & $\begin{array}{c}\text { Drain- } \\
\text { age area, } \\
\text { in square } \\
\text { miles. }\end{array}$ & Date. & $\begin{array}{l}\text { Maxi- } \\
\text { mum } \\
\text { rate. }\end{array}$ & Authority. \\
\hline $\begin{array}{l}\text { Des Plaines River, Riverside, } \\
\text { Ill. }\end{array}$ & (6i30) & June - 1892 & 19.05 & U. S. Geol. Sur , : An. \\
\hline $\begin{array}{l}\text { Verdigris River, Liberty, } \\
\text { Kans. }\end{array}$ & $3,16 \%$ & July 8,1914 & 16.43 & U.S. Geol.Sur. W.S.P. No. $17 \%$. \\
\hline Neosho River, Iola, Kans . ..... & $3,6 \%$ & July 10,1904 & 20.33 & Du. \\
\hline $\begin{array}{l}\text { Grand River, Grand Rapids. } \\
\text { Mich. }\end{array}$ & $4,9 \times 0$ & Mar. $2 \pi, 1904$ & 18.114 & Do. \\
\hline $\begin{array}{l}\text { Smoky Hill River, Ellsworth, } \\
\text { Kans. }\end{array}$ & 7,9801 & May 29,190:3 & $\because 1.43$ & U.S. Geol.Sur. W.S.P. No.!ti. \\
\hline $\begin{array}{l}\text { Kanawha River, Charleston, } \\
\text { W. Va. }\end{array}$ & 8,9000 & Aug. --, 1875 & 13.511 & Eng. News, May $25,1 \times 93$. \\
\hline Blue River, Manhattan, Kans. & 9,490 & May 31,1903 & 17.25 & U.S. Geol.Sur. W.S. P. No. 96. \\
\hline $\begin{array}{l}\text { Republican River, Junction, } \\
\text { Kans. }\end{array}$ & $25,8: 3 i$ & $\ldots$. do . ... & 11.81 & Do. \\
\hline $\begin{array}{l}\text { Mississippi River, St. Paul, } \\
\text { Minn. }\end{array}$ & $36,11 \times 5)$ & Apr.,- 1897 & 19.70 & U. S. Geol. Sur., 19 An. \\
\hline $\begin{array}{c}\text { Kansas River, Lecompton, } \\
\text { Kans. }\end{array}$ & 58,550 & May $81,190: 3$ & 3.98 & U.S.Geol.Sur. W.S.P. No. 96. \\
\hline
\end{tabular}

a Average flow for aay of maximum discharge.

Maximum rate of discharye of streams in southuestern Cinited States. [1n second-feet per square mile.]

\begin{tabular}{|c|c|c|c|c|}
\hline Stream and place. & $\begin{array}{c}\text { Drain- } \\
\text { age area, } \\
\text { in square } \\
\text { miles. }\end{array}$ & Date. & $\begin{array}{l}\text { Maxi- } \\
\text { mum } \\
\text { rate. }\end{array}$ & Authority. \\
\hline $\begin{array}{l}\text { Gallinas River, Las Vegas, } \\
\text { N. Mex. }\end{array}$ & 90 & Sept. 30,1904 & 129.10 & U.S. Geol. Sur. W.S. P. No.14i. \\
\hline Mora River, La Cueva. N. Mex - & 159 & Sept. 29, 1904 & 139.70 & Do. \\
\hline Cherry Creek, Colo & 175 & - & 57.100 & U.S. Geol.Sur. W.S.P. No. 81. \\
\hline Rapid Creek, Rapid, S. Dak ... & 320 & June 6.1904 & 2.85 & U. S. Geol. Sur. W.S.P. No. 14i. \\
\hline Salt Creek, at mouth, N. Mex - & 3,052 & Oct.,- 1904 & 4.10 & Do. \\
\hline Hondo River reservoir, N. Mex & $1,38 i$ & .... do ....... & 4.56 & Do. \\
\hline Canadian River, Logan, N. Mex & 11,411 & _. & a 12.29 & Do. \\
\hline Canadian River, Taylor, N. Mex & $2, \times 32$ & ... do $\ldots . . . .$. & $b 32.11$ & Do. \\
\hline $\begin{array}{l}\text { Canadian River, French, N. } \\
\text { Mex. }\end{array}$ & 1,478 & ..... do & c 105.56 & Do. \\
\hline $\begin{array}{l}\text { Pecos River, Fort Sumner, N. } \\
\text { Mex. }\end{array}$ & 6,191 & .....do . & 7.29 & Do. \\
\hline Pecos River, Roswell, N. Mex - & 14,840 & -...do....... & 3.75 & Do. \\
\hline $\begin{array}{l}\text { Redwater River, } \quad \text { Belle } \\
\text { Fourche, s. Dak. }\end{array}$ & 1,006 & June 5,1904 & 8.00 & Do. \\
\hline $\begin{array}{l}\text { Sapello River, Los Alamos, N. } \\
\text { Mex. }\end{array}$ & 221 & Sept.,- 1904 & 36.7 & Do. \\
\hline $\begin{array}{l}\text { Purgatory River, Trinidad, } \\
\text { Colo. }\end{array}$ & $: 42$ & Sept. 30,1904 & 61.2 & Do. \\
\hline Salt River, Roosevelt, Ariz ... . & 5,756 & Mar.,- 1893 & 36.0 & U.S.Geol. Sur. W.S.P. No.73. \\
\hline Verde River, McDowell, Ariz.. & 6,000 & ..... do _ . . . & $d 24.05$ & Do. \\
\hline Salt River, Ariz & 12,000 & Feb.,- 1891 & 24.69 & U.S. Geol. Sur. W.S.P. No.81. \\
\hline Gila River, Florence, Ariz_. .. & 17,750 & Feb. $1 \%, 1891$ & 7.50 & Do. \\
\hline $\begin{array}{l}\text { Pecos River, Santa Rosa, N. } \\
\text { Mex. }\end{array}$ & 2,649 & Sept. 30, 1904 & 17.56 & U.S. Geol.Sur. W.S. P. No.147. \\
\hline Mora River, Weber, N. Mex... & 422 & . . . do . . ..... & 65.70 & Do. \\
\hline $\begin{array}{l}\text { Rio Grande, Rio Grande, N. } \\
\text { Mex. }\end{array}$ & 11,250 & Oet.,- 1904 & 2.75 & Do. \\
\hline
\end{tabular}

${ }^{a}$ Rate for 12 hours. ${ }^{b}$ Rate for 7 hours. c Rate for 0.5 hour. ${ }^{d}$ Rate for 24 hours. 
Maximum rate of discharge of streams in c'alifornia.

[In second-feet per square mile.]

\begin{tabular}{|c|c|c|c|c|}
\hline Stream and place. & $\begin{array}{c}\text { Drain- } \\
\text { age area, } \\
\text { in square } \\
\text { miles. }\end{array}$ & Date. & $\begin{array}{l}\text { Maxi- } \\
\text { mum } \\
\text { rate. }\end{array}$ & Authority. \\
\hline $\begin{array}{l}\text { Mormon Canyon, Los Angeles, } \\
\text { Cal. }\end{array}$ & 15.5 & & 48.5 & U.S. Geol.Sur. W. S. P. No. 81. \\
\hline $\begin{array}{l}\text { Yuba River, Bowman dam, } \\
\text { Cal. }\end{array}$ & 19 & & 31.6 & Do. \\
\hline $\begin{array}{l}\text { Sweetwater River, Sweetwa- } \\
\text { ter dam, Cal. }\end{array}$ & 186 & Jan. -.1895 & 97.5 & Do. \\
\hline $\begin{array}{l}\text { Tuolumne River, Lagrange, } \\
\text { Cal. }\end{array}$ & 1,501 & & 31. 6 & Do. \\
\hline $\begin{array}{l}\text { San Joaquin River, Hampton- } \\
\text { ville, Cal. }\end{array}$ & 1,637 & Jan, -, 1881 & a 36.51 & Do. \\
\hline King River, State Point, Cal ... & $1,74: 2$ & Jan. $\ldots, 1901$ & « 25.22 & Do. \\
\hline Kern River, Rio Bravo, Cal... & 2,345 & May,- 1897 & a:.3 & Do. \\
\hline $\begin{array}{l}\text { Sacramento River, Iron Can- } \\
\text { yon, Cal. }\end{array}$ & 9,205 & Feb.,- 1904 & 23.47 & U.S.Geol.Sur. W.S.P. No.147. \\
\hline Yuba River, Smartsville, Cal - & 1,220 & $\ldots$ do . . & $a 49.0 \mathrm{z}$ & Do. \\
\hline Feather River, Oroville, Cal... & 3,350 & ..... do ....... & $\alpha 31.49$ & Do. \\
\hline Stony Creek, Fruto, Cal ....... & 760 & Mar.,- 1904 & a 29.21 & Do. \\
\hline
\end{tabular}

"Mean for day when discharge was a maximum.

\section{FORMULAS FOR MAXIMUM DISCHARGE AND AREA OF CROSS SECTION.}

Some of the data for streams in the northeastern United States are plotted in fig. 19, using the areas of drainage basin in square miles as abscisse and the maximum rates of flow as ordinates. The curve $\mathrm{A} \mathrm{B}$, whose equation is

$$
q=\frac{46,790}{M+320}+15
$$

has been drawn to represent the relation between rate of flow and size of drainage basin for this section of the country. In this equation, $M$ is the drainage area in square miles and $q$ the maximum discharge in cubic feet per second per square mile of drainage.

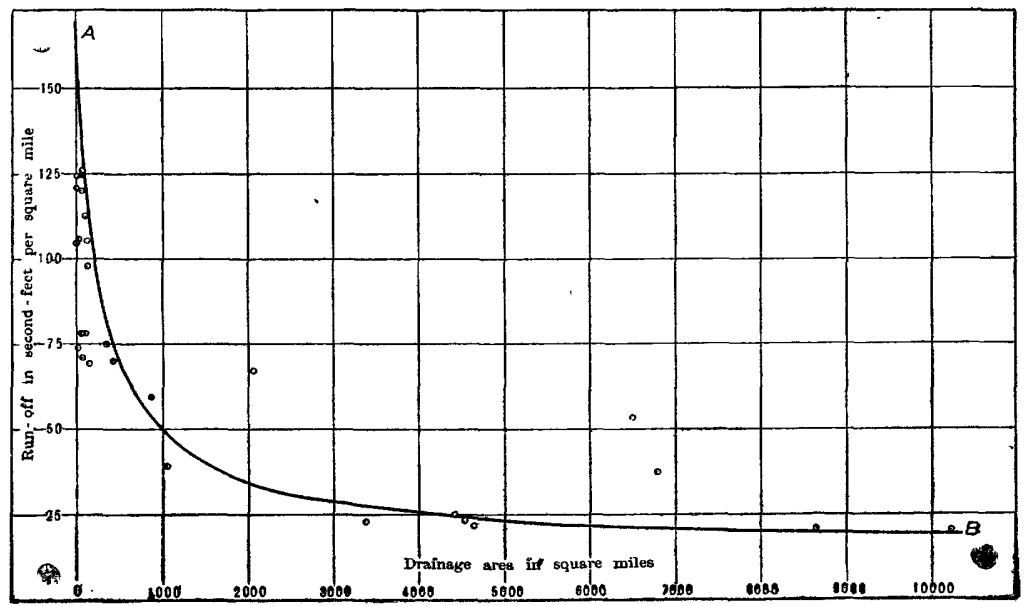

FIG, 19.-Curve showing relation between size of drainage basin and run-off per square mile. 
The following table has been prepared from this equation and gives the maximum rate of flow per square mile from drainage basins of various sizes in the northeastern part of the United States. Knowing the size of the drainage basin at a given place on a stream in this section of the country, the maximum discharge is found by multiplying the drainage area in square miles by the proper value found in this table.

Talues af $q$, the maximum rate of fow of streams, in terms of $\mathrm{M}$, the drainage area in square miles, in

$$
q=\frac{46,790}{M+320}+15
$$

\begin{tabular}{|r|r||r|r||r|r|}
\hline Value of $M$. & $\begin{array}{c}\text { Corre- } \\
\text { sponding } \\
\text { value of } q .\end{array}$ & Value of $M$. & $\begin{array}{c}\text { corre- } \\
\text { sponding } \\
\text { value of } q .\end{array}$ & Value of $M$. & $\begin{array}{c}\text { Corre- } \\
\text { sponding } \\
\text { value of } q .\end{array}$ \\
\hline 1 & 161 & 250 & 95 & 4,000 & 26 \\
\hline 5 & 159 & 500 & 72 & 5,000 & 24 \\
10 & 157 & 750 & 59 & 7,000 & 21.4 \\
20 & 153 & 1,000 & 51 & 10,000 & 19.5 \\
50 & 142 & 2,000 & 35 & & \\
100 & 126 & 3,000 & 29 & & \\
\hline
\end{tabular}

The mean velocity of flow in an open chaunel depends mainly on : (1) Slope of water surface; (2) shape of channel, its width, depth, and straightness; (3) roughness of bed and banks: ( $t$ ) position of mouth of tributary streams; (5) obstructions in channel, such as ice gorges, dams of logs, drift, bowlders, etc.

The formula in general use for computing the discharge of a stream is-

$$
Q=A T=A C \sqrt{R S}
$$

In this formula $Q=$ discharge in cubic feet per second, $A=$ area of waterway in square feet, $\Gamma=$ mean velocity in feet per second, $S=$ slope of surface, $R=$ hydraulic radius $=\frac{A}{P}$ where $P$ is the wetted perimeter, and $C=\frac{a+\frac{b}{n}+\frac{c}{S}}{1+\left(a+\frac{c}{S}\right) \sqrt{\frac{n}{R}}}$ where $a, b$, and $c$ are constants and $n$ is the coefficient of roughness of bed. Solving equation 1 , we have

$$
A=\frac{Q}{T^{T}}=\frac{Q}{C \sqrt{R S}}
$$

If a simple method ean be found for obtaining the value of $T$, then the waterway can be found by dividing $Q$ by $\mathrm{V}$. 
The following table gives the values of $I^{r}$ for slopes varying from 0.1 foot per thousand to 20 feet per thousand, and for values of $R$ from 2 to 25 feet, for the case where $n=0.035$. It covers all cases of flood flow of ordinary streams.

Table for finding the mean velocity in a channel from Kutter's formula when the cofficient of roughness $n=0.035$.

\begin{tabular}{|c|c|c|c|c|c|c|c|c|c|}
\hline \multirow{2}{*}{$\begin{array}{l}\text { Slope in } \\
\text { feet per } \\
\text { thou- } \\
\text { sand. }\end{array}$} & \multicolumn{9}{|c|}{ Hydraulic radius. } \\
\hline & 2. & 4. & 6. & 8. & 10. & 12. & 16. & 20. & 85. \\
\hline 0.1 & 0.6 & 1.1 & 1.5 & 1.8 & 2.2 & 2.4 & 3.0 & 3.6 & 4.1 \\
\hline .2 & .9 & 1.6 & 2.0 & 2.5 & 2.9 & 3.4 & 4.2 & $4 . \%$ & 5.5 \\
\hline .4 & 1.3 & 2.2 & 2.8 & 3.6 & 4.1 & 4.8 & 5.7 & 6.6 & 7.6 \\
\hline .6 & 1.6 & 2.7 & 3.5 & 4.3 & 5.0 & 5.7 & 6.9 & 8.0 & 9.1 \\
\hline .8 & 1.8 & 3.1 & 4.0 & 4.9 & 5.8 & 6.6 & 7.9 & 9.2 & 10.2 \\
\hline 1.0 & 2.1 & 3.6 & 4.6 & 5.5 & 6.5 & r.4 & 8.8 & 10.2 & 11.6 \\
\hline .1 .5$. & 2.5 & 4.3 & 5.5 & 6.7 & \%.9 & 9.0 & 10.8 & 12.5 & 14.0 \\
\hline 2.0 & 2.9 & 4.9 & 6.4 & 7.8 & 9.1 & 10.3 & 12.3 & 14.3 & 16.4 \\
\hline 3.0 & 3.7 & 6.0 & $\% 8$ & 9.5 & 11.2 & 12.8 & 15.0 & 17.5 & 19.8 \\
\hline 4.0 & 4.2 & 7.0 & 9.1 & 10.9 & 12.8 & 14.6 & $1 \% . \%$ & 20.2 & \\
\hline 6.0 & 5.0 & 8.5 & 10.7 & 13.7 & 15.4 & $1 \% .7$ & 21.5 & & \\
\hline 8.0 & 5.8 & 9.6 & 12.6 & 15.6 & 17.8 & 20.4 & & & \\
\hline 10.0 & 6.5 & 10.7 & 14.0 & 17.3 & 20.0 & & & & \\
\hline 15.0 & 8.0 & 13.3 & $1 \% .8$ & 21.0 & & & & & \\
\hline 20.0 & 9.3 & 15.3 & 20.0 & & & & & & \\
\hline
\end{tabular}

It can be shown that the hydraulic radius

$$
R=\frac{A}{P}=\left(\frac{(I+2 d) X}{(I+2 d) \sqrt{1+X^{2}}}\right) d
$$

in which $I$ is the bottom width of a trapezoidal section, $d$ is the depth, and $X$ is the slope of the sides. It can be seen from equation (3) that for any given values of $d$ and $X, R$ approaches $d$ as $I$ increases; for the case of floods, therefore, it may be assumed that $R=$ the difference in stage between high and ordinary low water. Any error in the assumption that $R=$ range of stage makes $R$ too large, the mean velocity too large, and the computed waterway too small. If desired $R$ can easily be obtained from a measurement of the chosen cross section.

Briefty stated, this method of finding the waterway at a given place on a stream consists in finding the drainage area in square miles above the place under consideration, the greatest change in stage of the stream at this place, and the slope of the surface. By multiplying the drainage area $M$ by $q$ (p. 190), we find $Q$; dividing $Q$ by $T$ 
(p. 191), using for $R$ the maximum range of stage, and for $S$ the measured slope of surface of stream, we have the necessary area of the waterway.

The greatest error in the use of this method will result from an incorrect measurement of the slope. The formula calls for slope of surface, and surface slope of a stream is not necessarily the slope of the bed. The slope is not the same at all stages nor always the same for a given stage. If the place under consideration is near the mouth of a large tributary the slope of the main stream will be affected by the stage of the tributary. Overflow and flooding of lowlands is frequently the result of backwater, due to reduction of surface slope. The smaller the șlope used the greater will be the computed waterway.

If there is a possibility of the waterway becoming partly clogged with drift, logs, or ice, or its being in the influence of backwater from a tributary, the computed area must be increased by a liberal amount.

The following tables give the maximum rate of flow of streams in various sections of the United States, the date of occurrence, the area of drainage above the station, and the authority. Nearly all these data were obtained with current meter; a few, however, were computed from cross-section and surface-slope measurements.

\section{GENERAL SUMMARY.}

Floods on northern streams may result almost entirely from the rapid melting of snow and ice, there being very little rain during the flood.

Floods on northern streams are sometimes produced by ice gorges. The stream may reach a high stage and large areas along the stream be overflowed, while the volume of discharge is comparatively small.

Many of the floods in the western part of the United States are of short duration, produced by heavy storms of short duration, popularly called " cloud-bursts."

The area submerged during a flood depends on slope of stream bed and size of channel. In the lower part of the drainage basin, where the slope is small, the area submerged is larger than in the upper part.

The channel of streams is frequently reduced in width through cities, and overflow results therefrom. The bridges across streams frequently obstruct the waterway to a considerable extent. 'Too many piers are used, and the pier protection prevents the natural deepening of the channel during floods. The abutments are frequently placed at the low-water line instead of near the high-water line. The control of streams subject to overflow should be in the hands of an engineer or a competent body of men who will prescribe 
the proper width of channel and the design of structures over them, and have charge of the work of overflow prevention.

Channel cross-section area should be a function of slope of stream as well as of drainage area and section of country.

Problems of stream control, protection of land along streams, and reclamation of swamp land are rapidly coming to the front in this country, and data bearing on their solution are in demand. In California and Kansas more has recently been done along these lines than in any other State.

The United States Reclamation Service is solving the flood problem in the semiarid region by the construction of reservoirs for the storage of the flood waters for use in irrigation. Destructive floods will eventually be unknown on the streams in this region.

IRR $147-05 \mathrm{M} \longrightarrow-13$ 



\section{N D E X.}

A.

Adams, N. Y., Sandy Creek (North Branch) at, maximum discharge of .....

Akin, N. Y., gorge at.

Albany, N. Y., rainfall at .

Albert, $\mathrm{N}$ Mex, rainfall at ....

Albuquerque, N. Mex., rainfall at ..........

Albuquerque Valley, N. Mex., description of.

Alderson, w. Va., Greenbrier River at, maximum discharge of ........

Greenbrier Riverat, measurements of. 179,180 Alford, Colo., rainfall at

Allegheny Plateau, character of ........... 23-24

Allegheny River, Pa., measurements of .... 180

Allendale, N. Y., Sandy Creek at, maximum discharge of ...

Alston, S. C., Broad River at, maximum discharge of

Altmar, N. Y., Beaverdam Creek at, maximum discharge of .

Salmon River at, maximum discharge of..

American basin, Cal., location and description of ...................... 13-14

Amity, Colo., flood at ................. 166

Amsterdam, N. Y., rainfall at..............

Anderson, R. H., work of

Androscoggin River, Me., maximum discharge of .................. 186

Arabela, N. Mex., rainfall at........... 132-133

Arizona, floods in .................... 115-120 rainfall in

Arkansas City, Kans., Arkansas River at, measurements of ......... 110,111, 169

flood near $110-111$

Arkansas River, bottom lands of, flood on. . 165-167

description of . . . . . . . . . . . . . . . 110,111

floods on .................. 109-113, 165-168

measurements of ..... $109,110,111,112,168,169$

Purgatory River flood on........... 165-169

rainfall stations on, figure showing .... 159

Arkansas Valley, Colo., flood in, damage

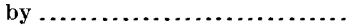

Armour Packing Company, levee constructed by ....................

Armstrong, J. A., acknowledgment to .....

on Cache la Poudre River flood, Colo ...................... 155-156

Army engineers, recommendations of ..... 65-66

Atchison, Topeka and Santa Fe Railway, damage to
Atchison, Topeka and Santa Fe Railway station at Trinidad, Colo., after flood, view of ................. 162

Augusta, Ga., Savannah River at, maximum discharge of ............ 187

B.

Bacon, F. A., records kept by ............. Barstow Irrigation Company's flume on Pecos River, Tex., destruction of, view of....................

Bay City, Mich., newspaper of, quoted on flood conditions in Michigan...

Beaver, Okla., Beaver Creek at, measurements of.

Page.

Beaver Creek, Okla., measurements of..... Beaverdam Creek, N. Y., maximum discharge of .....................

Bell ranch, N. Mex., rainfall at ............ Belle Fourche, s. Dak., Belle Fourche River at, messurements of ..... 57, 58 rainfall at .......................... 56 Redwater River at, maximum discharge of .................... 188

measurements of ................ 57,58

Belle Fourche River, S. Dak., flood on..... 55-59 flood on, damage by ................ 58-59 measurements of . . . . . . . . . . . . $56,57,58$ source and course of ................ 55-56 tributaries of ...................... 56

Belle Fourche River basin, S. Dak., description of ...................... 56-57

flgure showing portion of $\ldots \ldots \ldots \ldots \ldots . \quad 55$

rainfall in .......................... 56

Bennett, S. G., acknowledgment to....... 12

Big Sandy Creek in Troxton Canyon, Ariz., erosion of bank of, flgure showing .

Big Sandy River, extreme low-water conditions in, view of............ 182

Binghamtou, N. Y., rainfall at ........... 25 Susquehanna River at, measurements of ......................... 28

Bird Creek, Ind. T., description of......... 95

Black Hills drainage, part of, flgure showing $\ldots \ldots \ldots \ldots \ldots \ldots \ldots \ldots \ldots . . . \ldots \ldots$

Black River, N. Y., maximum discharge of ....................... 185, 186

Black Warrior River, Ala., maximum discharge of ................... 187

Blacklick, Pa., Blacklick Creek at, measurements of ................. 180 
Blacklick Creek, Pa,, measurements of ... 180

Bloomfield, Ind., flood at, damage by.....

Blue River, Kans., maximum discharge of.

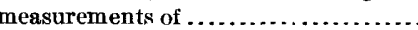

Bluff City, Tenn., Holston River (South Fork) at, measurements of ... 179,180

Bonham, Tex., rainfall at..............

Boonton, N. J., Rockaway River at, maximum discharge of.

Boston, Mass., Stony Brook at, maximum discharge of ................

Boulder, Golo., rainfall at...............

Boundbrook, N. J., Raritan River at, maximum discharge of ............

Bowman dam, Gal., rainfall at...........

Broad River, Ga., maximum discharge of..

Broad River, S. C., maximum discharge of. .

Bryson, N. C. Tuckasegee River at, maximum discharge of .............

Tuckasegee River at, measurements of. ...................... 179, 180

Buchanan, Va., James River at, maximum discharge of .................

Budlong Creek, N. Y., maximum discharge

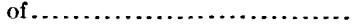
measurement of

Butte basin, Cal., location and description

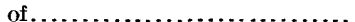

Butte Valley, Cal., rainfall at ............ Buttermilk Falls, Pa., Iandslide at........ Bye, $\mathbf{J}$ C., mention of

\section{c.}

Cache Creek, Cal . ...................... 16-17

Cache la Poudre River, Colo., fiood on ... 155-156 flood on, damage by ................. 156

measurements of $\ldots \ldots \ldots \ldots \ldots \ldots \ldots \ldots . .156$

Cache la Poudre River basin, Colo., figure showing ................. 155

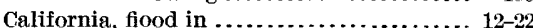
rainfall in ....................... 15-16 streams in, drainage area and maximum rate of discharge of......

Calvin, Ind. T., Canadian River at. measurements of . Y., Camden Creek at, maximum discharge of .............

Camden Creek, N. Y., maximum discharge of ......................... 185

Canadian River, N. Mex., description of.. 122-123

flood on ........................ 124-125

damage by . . . . . . . . . . . . . . . 128-130

maximum discharge of............. 188

measurements of $\ldots \ldots \ldots \ldots \ldots \ldots \ldots 124,125$

profiles of....................... 120, 121

tributaries of $\ldots \ldots \ldots \ldots \ldots \ldots \ldots \ldots \ldots . \quad 122$

Canadian River basin, description of..... 121, 122 floods in........................ 120-130

damage by .................... 128-130

map showing ................... 120

rainfall in ...................... 108-124

streams in, measurements of ........ 124 ,

$125,126,128,129$

obstruction of

128

Caney River, Kans., description of........
Canton, Ga., Etowah River at, maximum

discharge of ................ 187

Carlsbad, N. Mex., flood at, damage by .... 140

Lake Avalon dam near, failures of... 141-143

Pecos River at, dam on, views of, before, during, and after flood.... 134

measurements of .............. 183-134

rainfall at . . . . . . . . . . . . . . . . . 132-133

Carlton, Ga., Broad River at, maximum discharge of ............... 187

Carters, Ga., Coosawattee River at, maximum discharge of ............

Carthage, N. Y., Black River at, maximum discharge of $\ldots \ldots \ldots \ldots \ldots \ldots \ldots . \quad 186$

Castleman River, Pa., measurements of.... 180

Catawba, N. C., Catawba River at, maximum discharge of ............ 187

Catawba River, N. C., maximum discharge of ..........................

Cenicero, Colo., Rio Grande at, measurements of.

Centerville, N. Y., Trout Brook at, maximum discharge of . . . . . . . . . . .

Chain Bridge, D. C., Potomac Riverat, maximum discharge of ............

Channel, mean velocity in, table for flnding ........................ 191 Channels, obstruction of . ..........20,53, 54, 64$65,66,68-69,71-73,77-78,93,105-106$, $109,110,115,128,139,141,152,171,178$

Chanute, Kans., flood near............. 91

Neosho River at, liability to overflow .. $\quad 79$

Charleston, W. Va., Kanawha River at, maximum discharge of ........ 188

rainfall at .................... 175,176

Chatham, N.J., Passaic River at, maximum discharge of ............... 185

Chattahoochee River, Ga., maximum discharge of ..................

Chattanooga, Tenn., Tennessee River at, maximum discharge of.........

Tennessee River at, measurements of .. Chenung River, N.Y., maximum discharge of ........................ 186

Cherry Creek, Colo., maximum discharge of ........................

Cheyenne, Wyo., Crow Creek at, measurements of ................... 157

fiood at......................... 157

rainfall at ......................... 154

Chicago and Northwestern Railway along Whitewood Creek, S. Dak., damage to, view showing...........

Chisholm Creek, Kans., description of ..... 112 overfiow from .................... 112

Chittenden, Capt. H. H., mention of...... 65 Christian, H., acknowledgment to....... 143 Cimarron River, N. Mex., description of .. 122, 123 Cimarron River, Okla., measurements of... 125 Cincinnati, Ohio, rainfall at.......... 175, 177 Cisco, Cal., rainfall at................... 15 Clarks Ferry bridge, Pa., destruction of.... 25 Clear View, Colo., elevation at............ 160 rainfall at ........................ 160 Clouderoft, N. Mex., rainfall at......... 132-133 Coffeyville, Kans., flood near, damage by .. 103 
Coldspring Brook Mags maximum charge of $\ldots \ldots \ldots \ldots \ldots \ldots \ldots \ldots$

Colemans, N. Y., Oriskany Creek at, maximum discharge of ............ 185

Colorado, floods in ................ 150, 154-168 rainfall in .................. 154, 160-161 See also Denver district.

Colorado and Kansas canal dam, Arkansas River at, measurements of......

Columbus, Ohio, Olentangy River at, measurements of . ............... 179, 180

Scioto River at, measurements of ... 179, 180 Colusa, Cal., elevation at ............... 13 Colusa basin, Cal., location and description of ..........................

Confluence, Pa., Castleman River at, measurements of rainfall at $\ldots \ldots \ldots \ldots \ldots \ldots \ldots \ldots \ldots \ldots 175,176$

Youghiogheny River at, measurements

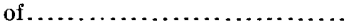
Connecticut River, maximum discharge of. Connor, ., data furnished by ............. Coosa River, maximum discharge of ....... Coosawattee River, Ga., maximum dis-

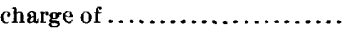
Copper Hill Wash, Ariz., measurements of. Cottee, —, acknowledgment to......... 120 Cottonwood River, Kans., description of ... 90-91 Council Grove, Kans., elevation of ........ 79 Crandall, N. Y., Independence Creek at, maximum discharge of .........

Cross section, area of, formulas for maximum discharge and........ 189-192

Croton dam, N. Y., Croton River at, maximum discharge of .............

Croton River, N.Y., maximum discharge of.

Croton River (South Branch), N. Y., maximum discharge of ............

Croton River (West Branch), N. Y., maximum discharge of .......... 18

Crow Creek, Colo., flood on ............ 156-158

flood on, damage by .............. 157, 158

Culebra Mountains, Colo., location of..... 158

Cumberland, Md., Potomac River (North Branch) at, maximum discharge

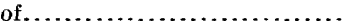

Cumberland River, Tenn., measurements

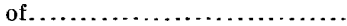

Cuyadutta Creek, N. Y., maximum discharge of $\ldots \ldots \ldots \ldots \ldots \ldots \ldots . . .$.

D.

Dams, failure of, floods due to

Davis County, Ind., flood in, damage by... 51

Dayton, Ohio, rainfall at. . . . . . . . . 175, 176

Deadwood, S. Dak., flood at, damage by...

Deer River, N. Y., Deer River at, maximum discharge of ................

Deer River, N. Y., maximum discharge of..

Deerfield, N. Y., Reels Creek at, maximum discharge of .................

Reels Creek at, measurements of......

Delaware River, N. J., maximum discharge of.
Delphi, Ind., Tippecanoe River at, meas urements of . . . . . . . . . . 179, 180

Denver, Colo., rainfall at............. 154

Denver district, floods in ............ 150-171

floods in, cause of ................. 152

damage by .................... 153

gaging stations established in...... 151-152

rainfall in ................... 154,160-161

Denver and Rio Grande Railway bridge, Trinidad, Colo., ruins of, yiew

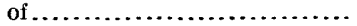

Des Plaines River, Ill., maximum discharge of ........................ 188

Devils River, Tex., flow of .............. 147

Devilsriver, Tex., Rio Grande at, measurements of ................. 145-146

Discharge, maximum, factors determining ................... 182-183

formulas for area of cross section and. 189-192

rate of $\ldots \ldots \ldots \ldots \ldots \ldots \ldots \ldots \ldots \ldots \ldots . \ldots 183-189$

Dobson, F. S., acknowledgment to....... 12

data furnished by . ............... 125, 134

Dodge City, Kans., Arkansas River at, measurements of............ 169

rainfall at $\ldots \ldots \ldots \ldots \ldots \ldots \ldots \ldots \ldots \ldots . . \ldots \ldots$

Dolgeville, N. Y., East Canada Crreek at, maximum discharge of....... 186

Dorsey, N. Mex., rainfall at............. 123

Dover, N. J., Rockaway River at, maximum discharge of ................. 185

Drought in Ohio River basin, effects of .. 181-182

paper on ........................ 172-182

Dundee, N. J., Passaic River at, maximum discharge of .............. 186

Dunsmuir, Cal., rainfall at............. 15

E.

Eagle, N. Mex., losses from flood between El Paso, Tex., and .......... 149-150

Eagle Pass, Tex., Rio Grande at, measurements of................. 145-146

East Canada Creek, N. Y., maximum discharge of $\ldots \ldots \ldots \ldots \ldots \ldots \ldots \ldots .186$

El Paso, Tex., losses from flood between Eagle, N. Mex., and. ......... 149-150

Rio Grandeat, measurements of. . 144, 145-146 El Paso and Northeastem Railway, damage to........................ 129

Elk River, Kans., contours, 50-foot, along, distance in miles between...... 96

description of . ..................... 95

Ellsworth, Kans., Smoky Hill River at, maximum discharge of........ 189

Smoky Hill River at, measnrements of. $\quad 76$

Elmira, N. Y., Chemung River at,maximum discharge of .............. 186

Emporia, Kans., elevation of............ 79

flood near : ....................... 90-91

J. R. Solden's mill near, water at, height of ................... 90-91

rainfall at ....................... 60

Erie Canal, description of ............. 33

Etowah River, Ga., maximum discharge of. $\quad 187$ Evansville, Ind., rainfall at............ 46-47 Evansville Courier, on damage at Hazleton, Ind., by Wabash River flood... 


\section{F.}

Fairmount, Pa., Schuylkill River at, maximum discharge of ........... 186

Fall River, Kans., character of .......... 104-105 contours, 50-foot, along, distance in miles between................. description of ......................... measurements of ................... 104

Fall River, Mass., Wantuppa Lake at, maximum discharge of ........... 184

Fall River Valley, flood in lower........ 104-105 Fallriver, Kans., Fall River at, measurements of. 104-105

Falmouth, Ky., rainfall at ............ 175, 176

Farmington, Mass, Sudbury River at, maximum discharge of ........... 185

Farmington River, Conn., maximum discharge of .

Fayette, W. Va., New River at, maximum discharge of ................ 187

New River at, measurements of ..... 179, 180

Feather River, Cal., description of ........ 14,15

maximum discharge of ............. $\quad 189$

measurements of ................... 16-17

Fellows, A. L., acknowledgment to ....... 12

Fish Creek (East Branch), N. Y., maximam discharge of ...................

Fish Creek (West Brauch), N.Y., maximum discharge of ..................

Flat River, R. I., maximum discharge of ..

Flint Hills, elevation of ..................

Floods, general summary on .......... 192-198

See individual streams.

Florence, Ariz., Gila River at, maximum discharge of .................

Forestport, N.Y., Black River at, maximum discharge of .................

Fort Collins, Colo., rainfall at..............

Fort Edward, N. Y., Hudson River at, maximum discharge of............ 186

Fort Gibson, Ind. T., flood near .......... 91-92

Neosho River near, measurements of... $\quad 92$

Fort Hunter, N. Y., flood at .

Schoharie Creek at maximnm discharge of ....................

Fort Meade, S. Dak., rainfall at........... Fort Scott, Kans., rainfall at. ............. Fort Smith, Ark., rainfall at.............. Fort Stanton, N. Mex, rainfall at ..... 132-133 Fort Sumner, N. Mex., Pecos Riverat, maximum discharge of ..............

Pecos River at, measurement of........ Fort Union, N. Mex., rainfall at............ Fort Worth and Denver Railroad, damage

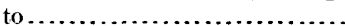

Fowler, Colo., rainfall at .................

Frederick, Md., Monocacy River at, maximum discharge of ..............

Frederick, Pa., Perkiomen Creek at, maximum discharge of ..............

Fredonia, Kans., flood at..................

French, N. Mex., Canadian River at, maximum discharge of ..............

Canadian River at, measurement of....

French Broad River, Tenn., measurements of $\ldots \ldots \ldots \ldots \ldots \ldots \ldots \ldots \ldots \ldots \ldots \ldots \ldots, 179,18$
Friendsville, Md., Youghiogheny River at, measurements of ............ 179,180 Fruto, Cal., Stony Creek at, maximum discharge of $\ldots \ldots \ldots \ldots \ldots \ldots \ldots . \quad 189$

G.

Gallinas River, N. Mex., description of .... 130

flood on .......................... 138-139

maximum discharge of............. 188 Genesee River, N. T., maximum discharge of $\ldots \ldots \ldots \ldots \ldots \ldots \ldots \ldots \ldots \ldots . . \ldots \ldots$

Georgetown, Cal., rainfall at............ 15

Gila River, Ariz., maximum discharge of.. 188 Glasgow, Va., North River at, maximum discharge of ................. 186

Globe, A riz., Copper Hill Wash at, measurements of ................... 119

flood at......................... 118-120

damage by .................... 120

Pinal Creek at, measurements of..... 118,119

rainfall at ....................... 118

Gorden, F. N., data furnished by ......... 103

Governor of California, engineer commission appointed by, report and recommendations of............ 21

Grand Haven, Mich., raiufall at.......... 41

Grand Rapids, Mich., flood at .......... 43,44 Grand River at, maximum discharge of. $\quad 188$ measurements of ..................42-43 rainfall at ........................ 41,42 temperature at ..................... 42

Grand River, Mich., area drained by...... 40 description of....................... 40

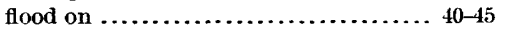

damage by ...................... 44

prevention of future damage by .... 44-45 flood profile of, table showing ......... 44 maximum discharge of............... 188 measurements of $\ldots \ldots \ldots \ldots \ldots \ldots \ldots \ldots, 42-43$ profile of, figure showing............. $\$ 1$ tributaries of ...................... 40 Grand River basin, Mich., description of... 40-41 flgure showing..................... 41 rainfall in ....................... $41-12$ temperature in .................... $41-42$ Great Falls, Md., Potomac River at, maximum discharge of ............. 187

Great River, Mass., maximum discharge of $\ldots \ldots \ldots \ldots \ldots \ldots \ldots \ldots \ldots \ldots \ldots \ldots \ldots \ldots$

Great Valley of California, location and description of ................. 12-13

134 Greeley, Colo., rainfall at ............... 154

123 Greenbrier River, W. Va., maximum discharge of .................. 186

measurements of .................. 179, 180 Greenville, Tenn., Nolichucky River at, measurements of $. . \ldots \ldots \ldots \ldots .179,180$ Grover, Colo., rainfall at ............... 154

H.

Hall, B. M., acknowledgment to ........ 12,143

Hamill, J. H., acknowledgment to......... 120

Hamptonville, Cal., San Joaquin River at, maximum discharge of......... 189

Hanna, F. W., acknowledgment to ........ 12 paper by, on Wabash River flood, Ind... 45-54 
Page.

Harrisburg, Pa., Juniata River at, measure-

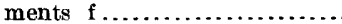
rainfall at $\ldots \ldots \ldots \ldots \ldots \ldots \ldots \ldots \ldots$. Susquehanna River at, maximum discharge of 187

measurements of .............. 27,29-30

Hartshorne, Ind. T., rainfall at ........... 60

Hastings, Mich., rainfall at .............. 41

Hazleton, Ind., flood at, damage by ...... 51,52

Helena, Cal., rainfall at................ 16

Herkimer, N. Y., Woodhull reservoir at, maximum discharge of.........

Highspire, Pa., ice gorgeat, dataconcerning.

Hinderlider, M. C., acknowledgment to ... paper by, on floods in the Denver district..................... 150-172

Hiwassee River, measurements of ....... 179, 180

Ho:kanum River, Conn., maximum discharge of ......................

Hoehne, Colo., elevation at ............... rainfall at .

Holly, Colo, rainfall at .

Holston River (South Fork), Teun., measurements of ............. 179, 180

Holyoke, Mass., Connecticut River at, maximum discharge of .............

Homestake mine, S. Dak., flood at ..........

Hondo reservoir, N. Mex., Hondo River near, measurements of....... 139,140

Hondo River, N. Mex., description of...... 130 floods on ......................... 139-140 maximum discharge of $\ldots \ldots \ldots \ldots \ldots \ldots, 188$ measurements of ................ 134, 139, 140

Hopkins, T. C., on topography of $W_{i} b_{i}$, River basin, Ind...............

Horton; R. E., acknowledgment to ........ 12

Hot Springs, N. Mex., flood at............ 138 Gallinas River at, measurements of.. 138,139 Houston, W. H., data furnished by ....... 167

Hoyt, J. C., acknowledgment to ...........

Hudson River, N. Y., maximum discharge of $\ldots \ldots \ldots \ldots \ldots \ldots \ldots \ldots \ldots \ldots \ldots \ldots+186$

Humboldt, Kans., elevation of............ 79 flood near . . . . . . . . . . . . . . . . . . $87-89$

Neosho River at, flood on, views of .... $\quad 88$

measurements of ................ 87-89

Hunts Pond, N. J., Pequest River at, maximum discharge of ..............

Huntsville, N. J., Pequest River at, maximum discharge of ..............

Hutehinson, Kans., Arkansas River at, measurements of ...........111, 169

\section{I.}

Ice gorge at Akin, $N$. Y,$\ldots \ldots \ldots \ldots \ldots \ldots$ at Bainbridge, $\mathrm{Pa} . \ldots \ldots \ldots \ldots \ldots \ldots \ldots$ at Duncannon, $\mathrm{Pa} . . . \ldots \ldots \ldots . . . . .$. at Highspire, $\mathrm{Pa}$

at Lockhaven, $\mathrm{Pa}$

at Middletown, $\mathrm{Pa} . . \ldots \ldots \ldots \ldots . . . . .$.

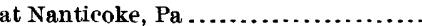

at Safe Harbor, $\mathrm{Pa}$

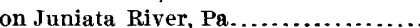

Ice gorges in Susquehanna River basin, data concerning.
Independence, Kans., floods near........ 101-108

rainfall at ......................... 60

Verdigris River at, measurements of . 102-103

Independénce Creek, N. Y., maximum dis-

charge of..e............... 185

Indian Territory, floods in ............ 120-130

Indiana, flood in ..................... 45-54

rainfall in ........................ 46-47

Indianapolis, Ind., flood at, damage by... 50-51 rainfall at ........................ 47

Indianapolis News, on damage done by

Wabash River flood... 49, 50-51, 51-52

Iola, Kans., flood near................ 85-87 Neosho River at, maximum discharge

of ........................ 188

measurements of ........... 81-85, 86, 93

Iron Canyon, Cal., Sacramento River at, maximum discharge of ........ 189

$$
\text { J. }
$$

Jackson, Mich., rainfall at................

Jacobs Creek, Pa., dam on, description and failure of .................. 172-173 James River, Va., maximum discharge of.. $\quad \mathbf{1 8 6}$ Johns Camp, Cal., rainfall at............. 15 Johnstown, N. Y., Cuyadutta Creek at, maximum discharge of ............ 185

Johnstown, Pa., flood at. ............... 113-114 rainfall at ........................ 113-114 Stony Creek at, maximum discharge of. $\quad 186$ measurements of ................ 114

Johnstown Tribune, on Johnstown flood... 113 Judson, N. C., Little I'ennessee River at, maximum discharge of........ 187

Little Tennessee River at, measurements of $\ldots \ldots \ldots \ldots \ldots \ldots \ldots \ldots \ldots \ldots \ldots \ldots \ldots+179,180$

Juep, - , on damage to engineering works at Indianapolis, Ind .......... 50-51

Julians, Cal., Stony Creek at, measurements

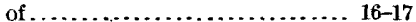

Junction, Kans., flood near ............. 73-74 Republican River at, maximum discharge of ................... 188

measurements of ................. 73 Juniata River, Pa., measurements of.... 26, 28, 29

\section{K.}

Kanawha River, W. Va., maxìmum discharge of.................... 188 Kansas, floods in ............... 59-113, 168-169 flood stations established in......... 151-152 levees in............................ 92-93 Nixon levee, description, costs, etc., of. 92-93 rainfall in ........................ 59-60 run-off in .................... southeastern, drainage basins in, Hzure showing .................... 80

streams in, character of ........... 79-80

Kansas city, area flooded at, view of...... 64 flood near.......................... 61-66 Kansas River at, measurements of... $62-63,64$ Missouri River at, measurements of. $62-63,64$ railway bridges at, view of........... 60 rainfall at ........................ 60

Kansas River, Kans., channel of, at Topeka, Kans., view of................. 
Kansas River, Kans.-Continued.

Page. flood on

61-78

damage by $\ldots \ldots \ldots \ldots \ldots \ldots \ldots \ldots .61,76$

prevention of future damage by... 64-66, $68-69,77-78$

flood discharge on, flgure showing..... 68 floods of 1903 and 1904, comparison of.. 75-76 maximum discharge of ............. 188 measurements of ....... $62-63,64,67,69,70-71$ obstruction of ..... 64-65, 66, 68-69, 71-73,77-78 railway bridges over, at Kansas City, Mo., view of.

Kennebec River, Me., maximum discharge

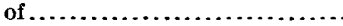

Kenwood, N. Y., Oneida Creek at, maximum discharge of ............

Kern River, Cal., maximum discharge of.. King River, Cal., maximum discharge of... Kingman, A riz., rainfall at................ Kinney, A., acknowledgment to ........... Kiskiminetas River, Pa., measurements of. Kittanning Pa:, Allegheny River at, measurements of .

Knoxville, Tenn., Tennessee Riverat, measurements of

\section{L.}

La Cueva, N. Mex., flood at. $127-128$ Mora River at, maximum discharge of. 188 La Plata River, Colo., channel of, obstruction of ...................... 171

flood on ....................... 169-171 damage by ..................... 171 measurements of .................. 171

La Plata River basin, Colo., figure showing. $\quad 170$ Lagrange, Cal., Tuolumne River at, maximum discharge of ............ 189

Lake Avalon dam, N. Mex., failures of.... 141-143 location and description of.......... 141-142 Lake Macmillan, N. Mex., Pecos River at, fluctuations of ................ 135

Lakeport, Cal., rainfall near ..............

Lamar, Colo., flood at rainfall at ...........................

Lambertville, N. J., Delaware River at, maximum discharge of ........

Langtry, Tex., Rio Grande at. measurements of .................. 145-146

Lansing, Mich., flood at, duration of...... 43 Grand River at, measurements of ...... 42-43 rainfall at ....................... 41,42 temperature at .................... 42

Laporte, Cal., rainfall at ................ 15

Laramie, wyo., rainfall at ............. 154

Las Animas, Colo., rainfall at ........... 160

Las Animas Leader, on Purgatory River flood.........................

Las Vegas, N. Mex., flood at.............. flood at, damage by .................. Gallinas River at, maximum discharge of ......................... 184

rainfall at ...................... 132-133

Laurel, Md., Patuxent River at, maximum diseharge of ...................

Laurel Hill Creek, Pa., measurements of...

Law rence, Kans, dam at, construction, cost, etc., of.
Lawrence, Kans-Continued.

Page.

flood near . . . . . . . . . . . . . . . .

damage by .................... 66

Kansas River at, measurements of ..... $\quad 69$

Lawrence, Mass., Merrimac River at, maximum discharge of ........... 186

Lecompton, Kans., flood near........... $66-69$

Kansas River at, flood discharge of, fignres showing ................ 68

maximum discharge of........... 188 measurements of . . . . . . . . . 64,67,69 Leroy, Kans., elevation of.............. $\quad 79$ Levees in Kansas, Neosho County........ 92-93 Liberty, Kans., Verdigris River at, maximum discharge of ............ 188

Verdigris River at, measurements of .. 97-101 Licking River, Ohio, measurements of... 179, 180 Lippincott, J. B., acknowledgment to ..... 12 Little Arkansas River, Kans,, deseription of. 112 Little Falls, N. J., Passaic River at, maximum discharge of ........... 186

I.ittle Falls, N. Y., gorge at ............. 33

Mohawk River at, flood discharge of.. $35-$ $36,38,39$

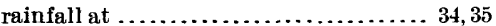

temperature at .................... 35

Little Tennessee River, N. C., maximum discharge of ................ 187

measurements of $\ldots \ldots \ldots \ldots \ldots \ldots \ldots \ldots .179,180$

Livermore, Colo., Cache la Poudre River at, measurements of ............. 156

Logán, N. Mex., Canadian River at, maximum discharge of ............ 188

Canadian River at, measurements of. 124,125 Logansport, Ind., Wabash River at, measurements of ......... 48-49, 179, 180 Looking Glass River, Mich., description of. Los Alamos, N. Mex., Sapello River at, flood on, damage by .............. 126

Sapello River at, maximum discharge of....................... 188

Los Angeles, Cal., Mormon Canyon at, maximum cischarge in ............ 189

Los Lunas, N. Mex., rainfall at........... 143

Louisville, Ky., Ohio River at, measurements of.................. 178

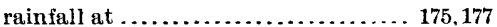

Lowell, Mass., Merrimac River at, maximum discharge of $\ldots \ldots \ldots \ldots \ldots . \quad 186$

Lyons Falls, N. Y., Black River at, maximum discharge of ........... 186

\section{M.}

McCalls Ferry, Pa., Susquehanna River at, measurements of .......... 27, 29-31

McConnellsville, N. Y., Fish Creek (West Branch) at, maximum discharge of .................... 185

McDonnell, Pa., flood at ................. 114

McDowell, Ariz., Verde River at, maximum discharge of $: . . \ldots \ldots \ldots \ldots \ldots . .188$

McEwing, M. S., acknowledgment to ...... 120 Macmillan dam, N. Mex., location and description of ...................

Macon, Ga., Ocmulgee River at, maximum discharge of ................ 187 
Page.

Mahoning River, Ohio, measurements of. 179,180 Mahwah, N. J., Ramapo River at, maximum discharge of .............

Manhattan, Kans., Blue River at, maximum discharge of .............

Blue River near, measurements of......

flood near

Kaneas River at, measurements of.... Mannsville, N. Y., Skinner Creek at, maximum discharge of ............ 18

Mannelitas River, N. Mex., overflow of... 126-127 Maple River, Mich., description of........ 40 Markham Ferry, Ind. T., elevation of...... 79 Marysville, Cal., water plain at, comparison of ...........................

Matthes, G. H., acknowledgment to ....... data furnished by .................. 129-130 Maxwell, N. Mex., rainfall near........... 123 Mechanicsville, N. Y., Hudson River at, maximum discharge of..........

Meeker, R. I., acknowledgment to........ 12

Merrimac River, Mass., maximum discharge of ......................... 186

Mesilla Park, N. Mex., rainfall at......... 143

Michigan, flood in..................... 40-45 rainfall in ......................... 41-42 temperature in .....................41-42

Middletown, Pa., ice gorge at, data concern-

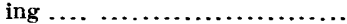

Middleville, N. Y., West Canada Creek at, maximum discharge of.........

Millville, W. Va., Shenandoah River at, maximum discharge of.........

Milstead, Ala., Tallapoosa River at, maximum discharge of ..............

Mississippi River, Minn., maximum discharge of

Missouri Pacific Railway bridge at Kansas City, Mo., view of .............

Missouri River, Kans., measurements of. 62-63,64 Missouri, Kansas and Texas Railway, damage to........................ 129-130

Mohawk River, N. Y., area drained by.....

flood on ............................ 32-40

damage by ..................... 40

maximum discharge of............. 185, 186 measurements of .............. 35-36, 38, 39

proflle of .......................... 34

slope of, table showing............... 33

source and course of................. 32

tributaries of ....................... 32

Mohawki River basin, N. Y., elevations in... $\quad 33$ flgure showing ...................... 34

rainfall in ....................... 33-35

streams in, description and measurements of............... $32,33,37-39$

temperature in ..................... 33-35

Monk, G. B., acknowledgment to......... $\quad 12$ Monocacy River, Md., maximum discharge of ...........................

Monthly Weather Review, on rainfall in eastern Kansas .................. 59-60

Moorehead, Tex., Pecos River at, measurements of........ 133-134, 137, 145-146

Moose River, N. Y., maximum discharge of. $\quad 186$ Mora River, N. Mex., flood on
Mora River, N.Mex., maximum discharge of 188 measurement of ................... 124,127

Mora Valley, N. Mex., flood in, damage by.. 127 Mormoll Canyon, Cal., maximum discharge of $\ldots \ldots \ldots \ldots \ldots \ldots \ldots \ldots \ldots \ldots \ldots . \ldots \ldots$

Motts dam, N. Y., West Cascade Creek at, maximum discharge of......... 185

Mount Carmel, Ill., rainfall at .......... 46,47

Wabash River at, measurements of..... 48,49 Mount Morris, N. Y., Genessee River at, maximum discharge of.........

Mount Pleasant, Pa., Tohickon Creek at, maximum discharge of ........ 185

Mount St. Helena, Cal., rainfall at......... 15, 16

Mount Shasta, Cal., rainfall at ............ 15

Murphy, E. C., paper by, on A method of computing cross-section area of waterways .............. 182-192

paper by, on Drouth in Ohio River drainage basin.............. 172-182

on Failures of Lake Avalon dam near Carlsbad, N. Mex ....... 141-143

on Floods due to failure of dams and reservoir walls.......... 172-173

on Kansas floods .............. 59-113 on Rio Grande floods, N. Mex..., 143-150

on Susquehanna River flood, Pa.... 22-32 on Troxton Canyon flood, Ariz... 115-118 Murphy, N. C., Hiwassee River at, measurements of.................. 179, 180

\section{N.}

Nashua River, Mass., maximum discharge of $\ldots \ldots \ldots \ldots \ldots \ldots \ldots \ldots \ldots . \quad 185$

Nashville, Tenn., Cumberland River at, flow of, measurements of ........... 180

Neodesha, Kans., flood at .............. 105

Neosho Rapids, Kans., flood near ......... 89-90 Neosho River at, measurements of.... 89-90 Neosho River, Kans., area drained by ..... 78 channel of, necessary width of......... 93 comparison of Verdigris River and..... 79 course and character of ....... 78-81, 89, 91,93 elevations on...................... 79 flood on ......................... 78-94

damage by $\ldots \ldots \ldots \ldots \ldots \ldots \ldots \ldots .64$ prevention of future damage by.... $\quad 94$

views of, at Humboldt, Kans....... 88

levees along ...................... 92-93 maximum discharge of............. 188 measurements of .. $81-85,86,87-89,90,91,92,93$ source of ......................... 78,79 tributaries of ...................... 79

New Hartford, N. Y., Starch Factory Creek at, maximum discharge of .....

Starch Factory Creek at, measurements of........................ 37-38

Sylvan Glen Creek at, maximum discharge of .................... 184

measurements of ................. 37

Neosho River basin, Kans., description of.. 79-94 figure showing ...................... $\quad 80$ Neshaming Creek, Pa., maximum discharge

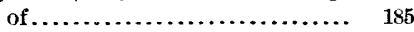

New Mexico, Canadian River in, tributaries of............................ 122 
Page.

New Mexico, Canadian River in, floods in. 120-150 rainfall in . ......... 123-124, 131-133, 143, 148

New River, maximum discharge of ....... 187 measurements of . . . . . . . . . . . . 179, 180

New York, floods in . . . . . . . . . . . . . . 32-40 rainfall in . . . . . . . . . . . . . . . . . . . $33-35$

temperature in . . . . . . . . . . . . . . . 33-35

New York Mills, N. Y., Sauquoit Creek at, maximum discharge of ........ Sauquoit Creek at, measurement of ....

Newell, F. H., acknowledgment to .......

Newport, Pa., Jumiata River at, measurements of . . . . . . . . . . . . . 28, 29

Newport, Tenn., Pigeon River at, measurements of ................ 179, 180

Ninemile Creek, N.Y., maximum discharge

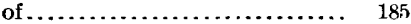

Nixon levee, Kans., cost, construction, etc. of .................... 92-93

Nolichucky River, Tenn., measurements of $. \ldots \ldots \ldots \ldots \ldots \ldots \ldots \ldots \ldots, 179,180$

North Platte, Nebr., rainfall at........... 60

North River, Va., maximum discharge of.. 186

Northumberland, Pa., Susquehanna River at, maximum discharge of .....

Northwestern Paciflc Railway bridge over Kansas River, at Kansas City, Mo., view of .................

O.

Oakdale, Ga., Chattahoochee River at, maximum discharge of .......... 187

Oakdale, Pa., flood at . .............. 114, 115 flood at, damage by ................ 115

Ocate Creek, N. Mex., description of . . .. 122, 123

Ocmulgee River, Ga., maximum discharge of $\ldots \ldots \ldots \ldots \ldots \ldots \ldots \ldots \ldots \ldots, 187$

Ohio River, measurements of .......... 178 navigation on, suspension of ......... 181

Ohio River basin, area and location of ... 173-174 drought in, effects of ............ 181-182 paper on................... 172-182 map showing . . . . . . . . . . . . . . . . . 174 principal streams in ................ 174 minimum flow of............. 180 run-off of $\ldots \ldots \ldots \ldots \ldots \ldots \ldots \ldots, 179$

rainfall in ..................... 174-177

Oil City, Pa., rainfall at . ............. 175

Oklahoma, floods in................. 120-130

Oklahoma, Okla., rainfall at ........... 60

Okmulgee, Ind. T., rainfall at........... 60

Oldtown, Tenn., French Broad River at, measurements of ......... 179, 180

Olentangy River, Ohio, measurements of. 179,180 Oneida Creek, N. Y., maximum discharge of.

Oriskany, N. Y., Oriskany Creek at, maximum discharge of .............

Oriskany Creek at, measurement of... Oriskany Creek, N. Y., maximum discharge

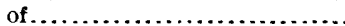

measurement of $\ldots \ldots \ldots \ldots \ldots \ldots \ldots \ldots$

Oroville, Colo., Feather Riverat, maximum discharge of
Osage Kiver, Kans., channel of, obstruction of ...................... 109

description of $\ldots \ldots \ldots \ldots \ldots \ldots \ldots \ldots \ldots, 106$

floods on. . . . . . . . . . . . . . . . . . . 106-109

damage by ..................., 108-109

prevention of future damage by ... 109

measurements of ................. 107-108

Osage River watersbed, area and description of ....................... 106

Oswego, Kans., elevation of............ 79

Ottawa, Kans., flood at, damage by....... 108

Osage River at, elevation of......... 106

measurements of .............. 107-108 Ottawa Republic, on Osage River flood at Ottawa .......................... 108 uttumwa, Kans., elevation of........... 79

\section{P.}

Pajarito Creek, N. Mex., description of .. 122, 123 Parshall, A. J., acknowledgment to...... . 12 on Crow Creek flood, Colorado..... 156-157 Passaic River, N. J., maximum discharge of $\ldots \ldots \ldots \ldots \ldots \ldots \ldots \ldots \ldots \ldots \ldots \ldots \ldots, 186$

Patuxent River, Md., maximum discharge of $\ldots \ldots \ldots \ldots \ldots \ldots \ldots \ldots \ldots, 185$

Pecos, Tex., Pecos River at, measurements of $\ldots \ldots \ldots \ldots \ldots \ldots \ldots \ldots \ldots$ 133-134, 137

Pecos River, Tex., Barstow Irrigation Company's flume on, destruction of, view of ...................... 136

dam on, at Carlsbad, N. Mex., views of, before, during, and after flood . 134

flood on ......................... 133-137

damage by ................... 136

measurements of . ........ 133-137, 145-146 profiles of, map................... 130, 131 source and course of ................ 130 tributaries of ...................... 131

Peros River basin, area of .............. 131

description of .................... 131

fioods in ....................... 130-141

damage by ................... 140-141 prevention of future damage by.... 141

map showing.................... 130

measurements in .......... 133-137, 138, 139 rainfall in ....................... 131-133 Pendleton, Colo., rainfall at.......... 170 Pennsylvania, flood in . ......... 22-32, 113-115

rainfall in . . . . . . . . . . . . . . . . $25,113,114$ Pequanock River, N. J., maximnm discharge of ...................

Pequest River, N. J., maximum discharge of..... 184

Perkiomen Creek, Pa., maximum discharge of ...................... 185

Philadelphia, Pa., Wissahickon Creek at, maximum discharge of ........ 185

Piedmont Plateau, character of .......... 24

Pigeon River, Tenn., measurements of. . 179, 180 Pinal Creek, Ariz., flood on . . . . . . . . . . 118-120 Pintado Creek, N. Mex., description of..... 130 Pleasant Valley, Ohio, Licking River at, measurements of ............ 179, 180

Point of Rocks, Md., Potomac Riverat, maximum discharge of .......... 187 
Page.

Point Rocks, N.Y., Fish Creek (East Branch) at, maximum discharge of .....

Pompton, N. J., Pequanock River at, maximum discharge of ..............

Ramapo River at, maximum discharge

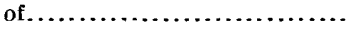

Port Republic, Va., North River at, maximum discharge of ..............

Portsmouth, Ohio, Ohio River at, measurements of

Potomac River, Md., maximum discharge of ...................... 186, 187

Potomac River (North Branch), Md., maximum discharge of ...............

Powers, Colo., flood at.

Precipitation. See Rainfall.

Presidio, Tex., Rio Grande at, measurements of .................. 145-146

Purgatory River, Colo., area drained by ... 158 description of ................... 158-160

erosion of banks of, at Prinidad, Colo., view showing $\ldots \ldots \ldots \ldots \ldots \ldots, 164$

flood on .......................... 158-169

damage by ................ 158,164-165

destruction by, at Trinidad, Colo., view of ..................... 162

maximum diseharge of............. 188

measurements of ................... 164

rainfall stations on, flgure showing .... $\quad 159$

source and course of ................. 158

Purgatory River basin, Colo., description of ...................... 158, 164

flgure showing....................... 159 rainfall in $160-161$

\section{Q.}

Quincy, Cal., rainfall at.

\section{$\mathbf{R}$}

Radford, Va., New River at, measurements of...................... 179, 180

Rainfall in California, Sacramento River basin ................... 15-16

in Indiana, Wabash River basin...... 46-47

in Kansas, eastern................. 59-60

in New Mexico, Canadian River basin ..................... 123-124

in New York, Mohawk River basin.... 33-35 in Ohio River basin ................ 174-177

in Pennsylvania, Susquehanna River basin ......................

in South Dakota, Belle Fourche River basin

Ramapo River, N. J., maximum discharge of ............................

Rapid, s. Dak., rainfall at................

Rapid Creek at, maximum discharge of.

measn rements of $\ldots \ldots \ldots \ldots \ldots \ldots \ldots \ldots \ldots \ldots \ldots \ldots$

apid Creek, S. Dak., description of ...... 56

maximum discharge of............... 188

measurements of ................ 57,58

Raritan River, N. J., maximum discharge of ........................

Raton, N. Mex., rainfall at.

186

123

Red Bluff, Cal., elevation at.
Red Bluff, Cal., rainfall at................

Page.

Sacramento River near, measurements

of $\ldots \ldots \ldots \ldots \ldots \ldots \ldots \ldots \ldots \ldots \ldots \ldots+16-17$

Red Cedar River, Mich., description of .... 40

Redwater River, S. Dak., description of.... $\quad 56$

maximum discharge of.............. 188

measurements of .................. 57,58

Reed, W. M., acknowledgment to......... 12

Reedy, o. T., paper by, on Globe flood, Arizona ................... 118-120

Reels Creek, N. Y., description of........ 32 maximum discharge of .............. 184

measurements of $\ldots \ldots \ldots \ldots \ldots \ldots \ldots \ldots . .38,39$

Reliance, Tenn., Hiwassee River at, measurements of .............. 179, 180

Republican River, Kans., maximum discharge of ................... 188

measurements of ................... 73

Reservoir walls, failure of, floods due to . 172-173

Rexford, N. Y., Mohawk River at, maximum discharge of ............ 186

Richards, D. P., data furnished by...... 124-125

Ridge Mills, N. Y., Mohawk River at, maximum discharge of ........... 185

Rio Bravo, Cal., Kern River at, maximum discharge of ............... 189

Rio Cebolla, N. Mex., flood discharge of ... 127 Rio Felix, N. Mex., description of ........ 130

Rio Grande, N. Mex., flood at........... 148 Rio Grande at, maximum discharge of. $\quad 188$

Rio Grande, floods on ................. 143-150

floods on, damage by.............. 149-150

maximum discharge of .............. 188

measurements of ................. 144, 145

Rio Grande basin, proflle of ............. $\quad 147$

Rio Peñasco, N. Mex., description of....... 130

Riverside, Ala., Coosa River at, maximum discharge of ................. 187

Riverside, Ill., Des Plaines River at, maximum discharge of ............ 188

Riverton, N. Mex., flood at ............. 136

Robb Run, Pa., flood on, description of .... 114

Robinson Run, Pa., channel of, obstrnetion

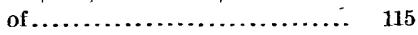

description of $\ldots \ldots \ldots \ldots \ldots \ldots \ldots \ldots, 114$

flood on .......................... 114-115

watershed of, description of $x \ldots \ldots \ldots \ldots .114$

Rochester, N. Y., Genesee River at, maximum discharge of ............ 186

Rociada, N. Mex., rainfall at ........... 123

Rock Creek, D. C., maximum discharge of.. 18.7

Rock Island Rail way, damage to ....... 129, 130

Rockaway River, N. J., maximum discharge of ........................ 185

Rocky Ford, Colo., rainfall at............. 160

Rome, Ga., Coosa River at, maximum discharge of .................. 187

Rome, N. Y., Mohawk River at, maximum discharge of ............... 185

Mohawk River at, measurements of ... $\quad 38$

rainfall at ........................ 34,35

temperature at ..................... 35

Rousevelt, Ariz., Salt River at, maximum discharge of ................ 188

Roswell, N. Mex., flood at............... 135

flood at, damage by $\ldots \ldots \ldots \ldots \ldots \ldots \ldots . \quad 140$ 
Roswell, N. Mex., Hondo River at, measurements of .................... 139 Pecos River at, maximum discharge of, 188 measurements of ............... 133-134 rainfall at ........................ 132-133

Rumford, Me., Androscoggin River at, maximum discharge of..........

Russell, W. G., acknowledgment to........ data furnished by .................... measurement by

\section{S.}

Sacramento, Cal., elevation at

rainfall at ........................ 16,20

Sacramento River, bottom lands along, reclamation of...............

channel of, obstruction of ...........

Alood on, damage by

occurrence and description of . . . . . 12-22

prevention of future damage by ... 21-22

maximum discharge of................ 189

measurements of $\ldots \ldots \ldots \ldots \ldots \ldots \ldots \ldots . .16-17$

source and course of . ................ 12,14

Sacramento River basin, Cal., location and description of................

map of

measurements in ................... 16-19

rainfall in .......................... 15-16

Sacramento Valley, location and description of ........................

St. Louis, Mo, rainfall at

St. Louis and San Francisco Railroad, dam-

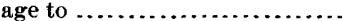

St. Paul, Minn., Mississippi River at, maximum discharge of

Saling, $P$ g. ments of.

Salisbury, N. C., Yadkin River at, maximum discharge of ............

Salmon River, N. Y., maximum discharge of

Salt Creek, N. Mex., description of ........ maximum discharge of .............. measurement of

Salt River, Ariz. . maximum discharge of .... Saluda River, S. C., maximum discharge of. San Joaquin River, Cal, maximum discharge of $\ldots . . . . . . . . . . . .$.

San Marcial, N. Mex., rainfall at.......... 143

Rio Grande at, measurements of .... 144, 145

Sanchez, N. Mex., flood at, damage by .... 129

Sandy Creek, N.Y., maximum discharge of. 185

Sandy Creek (North Branch), N. Y., maximum discharge of . ............

Santa Clara, Colo., rainfall at ............

Santa Fe, N. Mex., flood at.

rainfall at .........................

Santa Fe Rail way bridge, Troxton Canyon Ariz., ruins of, view showing ...

Santa Rosa, N. Mex., flood at

Pecos River at, maximum discharge of 188 measurements of . ............. 133-134

Sapello, N. Mex., Manuelitos River at, overflow of.................... 126-127

Sapello River, N. Mex., flood on ........ 126-127
Sapello River, N. Mex., maximum dis charge of $\ldots \ldots \ldots \ldots \ldots \ldots \ldots \ldots .188$

measurements of $\ldots \ldots \ldots \ldots$

Sauquoit Creek, N. Y., maximum discharge of ............................ 185

measurement of $\ldots \ldots \ldots \ldots \ldots \ldots \ldots \ldots . .38$

Savannah River, Ga., maximum discharge of . . ....................... 187

Sawkill, N.J., maximum discharge of...... 184

Scantic River (North Branch), Conn., maximum discharge of .............

Schoharie Creek, N.Y., maximum discharge of . . . . . . . . . . . . . . . . . . . . .

Schuylkill River. Pa., maximum discharge of ........................ 186 Scioto River, Ohio, measurements of ..... 179, 180 Scottdale, Pa., dam near, failure of, view showing ................... 162

Scottsdale Valley, Pa., flood in......... 172-173

Scranton, Pa., rainfall at............. 25

Shasta, Cal., rainfall at.............. 15

Shenandoah River, W. Va., maximisin discharge of ................... 186

Shoals, Ind., description of ......... tits ..... 54

White River (East Branch) at, mosurements of..............

Skinner Creek, N. Y., maximum ditharge of ................... 181

Smartsville, Cal., Yuba River at, maximum discharge of ................ 189

Yuba River at, measurements of . ...... 18-19 Smartswood Lake, N. J., maximum discharge of ................. 184 Smoky Hill River, Kans., maximum dis. charge of ................ 188 measurements of $\ldots \ldots \ldots \ldots \ldots \ldots \ldots \ldots 74,76$ Socorro, N. Mex., rainfall at ........... 143 Solomon, Kans., flood near............. 74-75 Smoky Hill River at, measurements of. $\quad 74$ South Dakota, flood in ............... 55-59 rainfall in ............................ 56 Spearfish, \$. Dak., flood at, damage by.... $\quad 59$

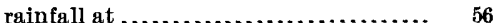
Spearfish Creek, S. Dak., flood on, damage by $\ldots \ldots \ldots \ldots \ldots \ldots \ldots \ldots \ldots \ldots 58-59$ Springer, N. Mex., rainfall at .......... 123 Starch Factory Creek, N. Y., description of. $\quad 32$ maximum discharge of .............. 184 measurements of . ................ 37-38, 39 State Point, Cal., King River at, maximum discharge of $\ldots \ldots \ldots \ldots \ldots \ldots \ldots$

Stickney, Col. Amos, mentiou of......... 65 Stittville, N. Y., Nine Mile Creek at, maximum discharge of .............

Stockton, N. J., Delaware River at, maximum discharge of ............ 186

Stony Brook, Mass., maximum discharge of. $\quad 184$ Stony Creek, Cal., maximum discharge of. 189 measurements of ................... 16-17 Stoney Creek, Pa., maximum discharge of. 186 measurements of $\ldots \ldots . . . . .114$ Sudbury River, Mass., maximum discharge

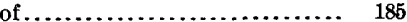
Sugar City, Colo., rainfall at ............ 160 Sullivan, V. L., acknowledgment to ...... 143 data furnished by . . . . . . . . . . . 134, 135, 142 
Page.

Sunbury, Pa., ice gorge at, damage by .... 26-27 Susquehanna River, Pa., description of.... 23-24

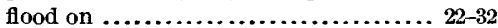

at Yorkhaven, Pa., March 8, 1904,

at its height, view showing .... 22

damage by $\ldots \ldots \ldots \ldots \ldots \ldots \ldots \ldots 22,31$

prevention of future damage by ... $\quad 32$

ice gorge of 1875 on, at Wilkesbarre,

Pa., view of $\ldots \ldots \ldots \ldots \ldots \ldots \ldots, 24$

ice gorges in, data concerning ....... 25-27

maximum discharge of ............ 186, 187

measurements of .................. 27-30

proflle of, table showing ............. 24

tributaries of ...................... 24

Susquehanna River (West Branch), Pa., maximum discharge of ........

Susquehanna River basin, Pa., flgure show-

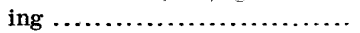

floods in, occurrence of ...............

location and description of $\ldots \ldots \ldots \ldots .23-24$

measurements in.................... 27-30

rainfall in ........................... 25

Sutter basin, Cal., location and description of ..........................

Sweetwater River, Cal., maximum discharge of ...................

Sylvan Glen Creek, N. Y., maximum discharge of ................... 184

measurements of ................. $37,38,39$

Syracuse, Kans., Arkansas River at, measurements of .................

T.

Table Mound, Kans., location and description of.

Tallapoosa River, Ala., maximum discharge of ................................

Taos, N. Mex., rainfall at .................

Taylor, N. Mex., Canadian River at, maximum discharge of ..............

Canadian River at, measurement of.... Temperature in N. Y., Mohawk River basin. 33-35 Tennessee. River, Tenn., maximum discharge of ................... 187

measurements of ................. 179, 180

Terre Haute, Ind., rainfall at .......... 175,176

Tippecanoe River, Ind., measurements of. 179, 180

Tobish, T., acknowledgement to...........

Todd, G. T., data furnished by.............

Tohickon Creek, Pa., maximum discharge of......................... 185

Topeka, Kans., floods near................ 70-73

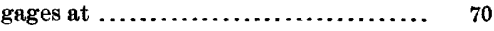

Kansas River at, channel of, view of.. $\quad 72$ cross section of, figure showing .... 72 flooded area on, flgure showing.... 72 measurements of ............60-63,70-71 rainfall at ......................... 60

Tracy, F. G., acknowledgment to......... 143 data furnished by ................. 142

Trementina Creek, N.Mex., description of. 122, 123

Trinidad, Colo., elevation at............. 160

flood at........................ 161-165 area overflowed and eroded by, figure showing.................. cause of
Page.

Trinidad, Colo., flood at, damage by....... 162

Purgatory River at, erosion of banks of, view showing

164

flood on, view showing destruction caused by .................. 162

maximum discharge of .......... 188

measurements of ................. 164

railway bridge ruins at, view of ...... 72

railway station at, after flood, view of. 162

rainfall at ........................ 160

Trout Brook, N. Y., maximum discharge of. 184

Troxton Canyon, A riz., Big Sandy Creek in, erosion of banks of, figure show-

ing $\ldots \ldots \ldots \ldots \ldots \ldots \ldots \ldots \ldots . \quad 116$

description of .................. 115-117

floods in ........................ 115-118

damage by ................... 118

railway bridge in, description of ....... 117

design of, figure showing......... 117

ruins of, view of................ 116

Santa Fe Railway in, relocation of, flgure showing $\ldots \ldots \ldots \ldots \ldots \ldots \ldots, 116$

Tuckasegee River, N. C., maximum discharge of ................. 187

measurements of .................. 179,180

Tuolumne River, Cal., maximum discharge of $\ldots \ldots \ldots \ldots \ldots \ldots \ldots \ldots \ldots \ldots \ldots \ldots$

Turquillo Valley, N. Mex., flood in ........ 128

Tuscaloosa, Ala., Black Warrior River at, maximum discharge of ......... 187

Twin Rocks Bridge, N. Y., West Canada Creek at, measurements of ..... 39-40

\section{U.}

United States, central, streams in, drainage area and maximum rate of discharge of

northeastern, streams in, drainage area and maximum rate of discharge of...................... 184-187

southeastern, streams in, drainage area and maximum rate of discharge of $\ldots \ldots \ldots \ldots \ldots \ldots \ldots \ldots \ldots \ldots .187$

United States Reclamation Service, work of. 193 United States Weather Review, data concerning ice gorges from ........ 25-27

United Zine and Chemical Company, levee constructed by .............. $\mathbf{1 6}$

Ute Creek, N. Mex., description of . ...... 122, 123

flood on.......................... 125-126

measurements of $\ldots \ldots \ldots \ldots \ldots \ldots \ldots \ldots, \quad 125$

Utica, N. Y., Budlong Creek at, maximum discharge of ............... 184

Budlong Creek near, measurement of.. $\quad 38$

Reels Creek near, measurements of .... 38,39

Stareh Factory Creek near, measurements of .................. 37-38, 39

Sylvan Glen Creek near, measurements of ....................... $37,38,39$

V.

Verde River, Ariz., maximum discharge of. $\quad 188$ Verdigris River, area drained by .......... 95 channel of, neeessary width of....... 105-106 comparison of Neosho River and...... 79 
Verdigris River, contours, 50-foot, along, distance in miles between........ 96 course and character of ........ 94-95, 96, 103 floods on ........................ 94-106 damage by .................... 106 maximum discharge of............... 188 measurements of ............ 97-101, 102-103 source of.......................... 94 tributaries of $\ldots \ldots \ldots \ldots \ldots \ldots \ldots \ldots \ldots .95$ watershed, description of ........... 95-96 Vermejo, N. Mex., rainfall at............ 123

\section{w.}

Wabash River, Ind., channel of, obstruction of ....................... 53,54 description of $\ldots \ldots \ldots \ldots \ldots \ldots \ldots \ldots \ldots, 45-46$ flood on ......................... 45-54 damage by $. . \ldots \ldots \ldots \ldots \ldots \ldots \ldots .49-52$

prevention of future damage by ... 52-54 measurements of . ...........48,49,179,180

Wabash River basill, Ind., area covered by . $\quad 45$ description of .................... 45-46 flgure showing ..................... 45 rainfall in ........................ $46-47$ topography of ..................... 46

Walnut River, Kans., description of....... 112 flood on ....................... 112-113

Walter, R. F., acknowledgement to....... 12

Wanaque River, N. J., maximum discharge

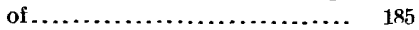

Wantuppa Lake, Mass., maximum discharge of . .........................

Warren, Maj. J. G., mention of ............

Washington, D. C., Rock Creek at, maximum discharge of ..............

Water supply, lack of, remedy for ..........

in Ohio River basin, decrease of, on account of drought ........... 181-182

Waterloo, S. C., Saluda River at, maximum discharge of ..............

Waterville, Me., Kennebec River at, maximum discharge of.............

Waterways, method of computing crosssection area of, paper on ..... 182-192

Watrous, N. Mex., flood at ............. 127

Mora River at, measurement of....... 124

Waynoka, Okla., Cimarron River at, measurements of

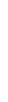

Weber, N. Mex., flood at................ 127

Mora River at, maximum discharge of. 188

West Canada Creek, N. Y., maximum discharge of . ................. 185, 186

measurements of ................... $39-40$

Westfield, Mass., Great River at, maximum discharge of .............. 184, 186

Wheatfields, Ariz., Pinal Creek at, measurement of.

120

\section{Page.}

Wheeling, w. Va., Ohio River at, measurements of......................

Whippany, N. J., Whippany River at, maximum discharge of .

Whippany River, N. J., maximum discharge of.

185

185

White River, Ind., bridge over, destruction of ............................

White River (East Branch), Ind., measurements of ............. 48-49,179, 180

Whitewood Creek, S. Dak, Chicago and Northwestern Railway along, damage to, view showing ...... 60

flood on, damage by ................ 58,59 .

Wichita, Kans., Arkansas River at, meas-

- urements of ................ 109,111

flood near ..................... 111-112

damage by .................... 112

rainfall at .......................... 60

Wilkesbarre, Pa., flood at, damage by..... 26

Susquehanna River at, ice gorge of $\mathbf{1 8 7 5}$

on, view of ................... 24

measurements of ................. 27,29

Williamsport, Pa., Susquehanna River (West Branch) at, maximum discharge of ................. 186

measurements of $\ldots \ldots \ldots \ldots \ldots \ldots \ldots \ldots .28,29$

Williamstown, Mass., Williamstown River at, maximum discharge of ..... 184

Williamstown River Mass., maximam discharge of $\ldots \ldots \ldots \ldots \ldots \ldots \ldots .184$

Winfield, Kans., gage at................ 112

rainfall at ................... 60

Wissahickon Creek, Pa., maximum discharge of .................. 185

Woodhull reservoir, N. Y., maximum discharge at.................. 184

Wyoming, flood in ............ 150, 154, 156-158 rainfall in ....................... 154 See also Denver district.

\section{Y.}

Yadkin River, N.C., maximum discharge of. 187 Yolo, Cal., Cache Creek at, measurements of........................ 16-17

Yolo basin, Cal., location and description of ...........................

Yorkhaven, Pa., Susquehanna River at. view showing flood of March 8 , 1904, at its height.............

Youghiogheny River, Pa., measurements of..................... 179, 180

Youngstown, Ohio, Mahoning River at, measurements of ........... 179,180

Yuba River, Cal., description of.......... 14, 15 maximum discharge of............... 189

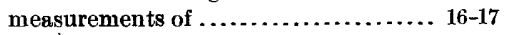




\section{PUBLICATIONS OF UNITED STATES GEOLOGICAL SURVEY.}

[Water-Supply Paper No. 147.]

The serial publications of the United States Geological Survey consist of (1) Annual Reports, (2) Monographs, (3) Professional Papers, (4) Bulletins, (5) Mineral Resources, (6) 11 ater-Supply and Irrigation Papers, (7) Topographic Atlas of United States-folios and separate sheets thereof, $-(8) \times($ trologic Atlas of the United States-folios thereof. The classes numbered 2,7 , and 8 are sold at cost of publication; the others are distributed free. A circular giving complete lists may be had on application.

Most of the above publications may he obtained or consulted in the following ways:

1. A limited number are delivered to the Director of the Survey, from whom they may be obtained, free of charge (except classes 2, 7, and 8), on application.

2. A certain number are allotted to every member of Congress, from whom they may be obtained, free of charge, on application.

3. Other copies are deposited with the Superintendent of Documents, Washington, D. C., from whom they may be had at prices slightly above cost.

4. Copies of all Government publications are furnished to the principal public libraries in the large cities throughout the United States, where they may be consulted by those interested.

The Professional Papers, Bulletins, and Water-Supply Papers treat of a variety of subjects, and the total number issued is large. They have therefcre been classified into the following series: A, Economic geology; B, Descriptive geology; C, Systematic geology and paleontology; D, Petrography and mineraiogv; E, Chemistry and physics; F, Geography; G, Miscellaneous; H, Forestry; I, Irrigation; J, Water storage; K, Pumping water; L, Quality of water; $\mathrm{M}$, General hydrographic investigations; $N$, Water power; $\mathrm{O}$, Underground waters; $\mathrm{P}, \mathrm{Hydrographic}$ progress reports This paper is the fifteenth in Series M, the complete list of which follows. ( $P P=$ Professional Paper; $B=$ Bulletin; WS=Water-Supply Paper):

SERIES M-GENERAL Hydrographic InVestigations.

Ws 56. Methods of stream measurement. 1901. 51 pp., 12 pls.

WS 64. Accuracy of stream measurements, by E. C. Murphy. 1902.99 pp., 4 pls.

WS 76. Observations on the flow of rivers in the vicinity of New York City, by H. A. Pressey. 1902 . 108 pp., 13 pls.

WS 80. The relation of rainfall to run-off, by G. W. Rafter. 1903.104 pp.

WS 81. California hydrography, by J. B. Lippincott. 1903.488 pp., 1 pl.

WS 88. The Passaic flood of 1902, by G. B. Hollister and M. O. Leigliton. $1903.56 \mathrm{pp} ., 15 \mathrm{pls.}$

WS 91. Natural features and economic development of the Sandusky, Maumee, Muskingum, and Miami drainage areas in Ohio, by B. H. Flynn and M. S. Flynn. 1901.130 pp.

Ws 92 . The Passaic flood of 1903 , by M. 0 . Leighton. 1904. 48 pp., 7 pls.

WS 94. Hydrographic manual of the United States Geological Survey, prepared hy E. C. Murphy. J. (.. Hoyt, and G. B. Hollister. 1904. 76 pp., 3 pls.

WS 95. Accuracy of stream measurements (second edition), by E. C. Murphy. 1904.169 pp., 6 pls.

WS 96 Destructive floods in the United States in 1903, by E. C. Murphy. 1904.81 pp., 13 pls.

WS 106. Water resources of the Philadelphia district, by Florence Bascom. 1904.75 pp., 4 pls.

WS 109. Hydrography of the Susquehanna River drainage basin, by J. C. Hoyt and R. H. Anderison. 1904. 215 pp., 28 pls.

WS 116. Water resources near Santa Barbara, Cahifornia, by J. B. Lippincott. 1904.99 pp., 8 pls.

WS 147. Destruetive floods in the United States in 1904, by E. C. Murphy and others. 1905.206 pp.. 18 pls.

Correspondence should be addressed to

The Director,

United States Geological Survey, W ASH INGTON, D. C.

November, 1905. 



\section{LIBRARY CATALOGUE SLIPS.}

[Mount each slip upon a separate card, placing the subject at the top of the second slip. The name of the series should not ine repeated on the series card, but the additional numbers should be added, as received, to the first entry.]

\section{Murphy, Edward Charles, I859-}

. : Destructive floods in the United States in 1904, by Edward Charles Murphy and others. Washington, Gov't print. off., I905.

206, iii p. illus., XVIII pl., liagre. $3^{\mathrm{m}}$. (U. S. Geological survey. Water-supply and irrigation paper no. 147)

Subject series: M, General hydrographic investigations, 15.

Contains papers by S. G. Bennett, E. C. Murphy, R. E. Horton, F. W. Hanna, R. F. Walter, O. T. Reedy, F. S. Dotson, A. B. Monk, M. C. Hinderlider, R. I. Meeker, T. Tobish.

1. Floods-U. S.

\section{Murphy, Edward Charles, I859-}

.. Destructive floods in the United States in 1904, by Edward Charles Murphy and others. Washington, Gov't print. off., I905.

206, iii p. illus., XVIII pl., diagrs. 283. (U. S. Geological survey. Water-supply and irrigation paper no. 147)

Subject series: M, General hydrographic unvestigations, 15.

Contains papers by S. G. Bennett, E. C. Murphy, R. E. Horton, F. W. Hanna, R. F. Walter, O. T. Reedy, F. S. Dolson, G. B. Monk, M. C. Hinderlider, R. I. Meeker, T. Tobish.

1. Floods-U. S.

\section{U. S. Geological survey.}

Water-supply and irrigation papers.

no. I47. Murphy, E. C. Destructive floods in the United States in 1904. I905.

U. S. Dept. of the Interior. see also

U. S. Geological survey.

IRR $147-05-14$

III 